\title{
ANÁLISE DE PILARES DE CONCRETO DE ALTA RESISTÊNCIA COM ADIÇÃO DE FIBRAS METÁLICAS SUBMETIDOS À COMPRESSÃO CENTRADA
}

\author{
Ana Elisabete Paganelli Guimarães
}

Tese apresentada à Escola de Engenharia de São Carlos, da Universidade de São Paulo, como parte dos requisitos para obtenção do título de Doutor em Engenharia de Estruturas

ORIENTADOR: José Samuel Giongo

São Carlos

1999 
\begin{tabular}{l} 
Clase.tcse-6esc \\
cutt. $\frac{2639}{\text { Tombo } 0127 / 99}$ \\
\hline
\end{tabular}

sigs 1034424

Guimarães, Ana Elisabete Paganelli

Análise de pilares de concreto de alta resistência com adição de fibras metálicas submetidos à compressão centrada / Ana Elisabete Paganelli Guimarães. -- São Carlos, 1999.

Tese (Doutorado) -- Escola de Engenharia de São Carlos-Universidade de São Paulo, 1999.

Área: Engenharia de Estruturas.

orientador: Prof. Dr. José Samuel Giongo.

1. Concreto de alta resistência. 2. Concreto com fibras. 3. Fibras metálicas. 4. Pilares.

5. Experimentação. I. Título. 


\section{FOLHA DE APROVACÃO}

Candidata: Engenheira ANA ELISABETE PAGANELLI GUIMARÃES

Tese defendida e aprovada em 07-05-1999

pela Comissão Julgadora:

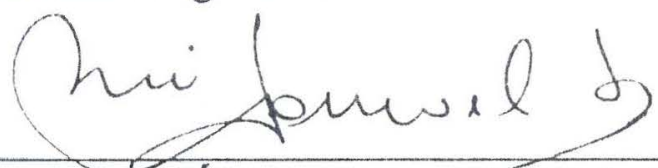

\section{Prof. Doutor JOSÉ-SAMUEL GIONGO (Orientador)}

(Escola de Engenharia de São Carlos - Universidade de São Paulo)

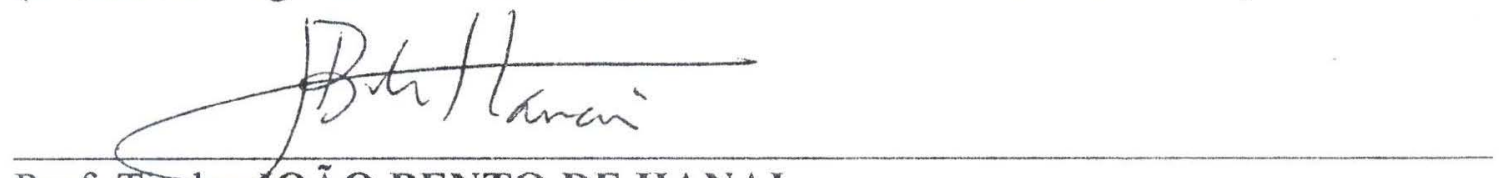

\section{Prof. Titutar JOÃO BENTO DE HANAI}

(Escola de Engenharia de São Carlos - Universidade de São Paulo)

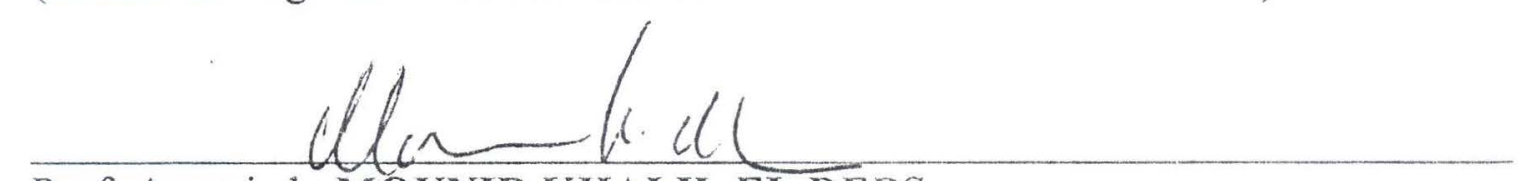

Prof. Associado MOUNIR KHALIL EL DEBS

(Escola de Engenharia de São Carlos - Universidade de São Paulo)

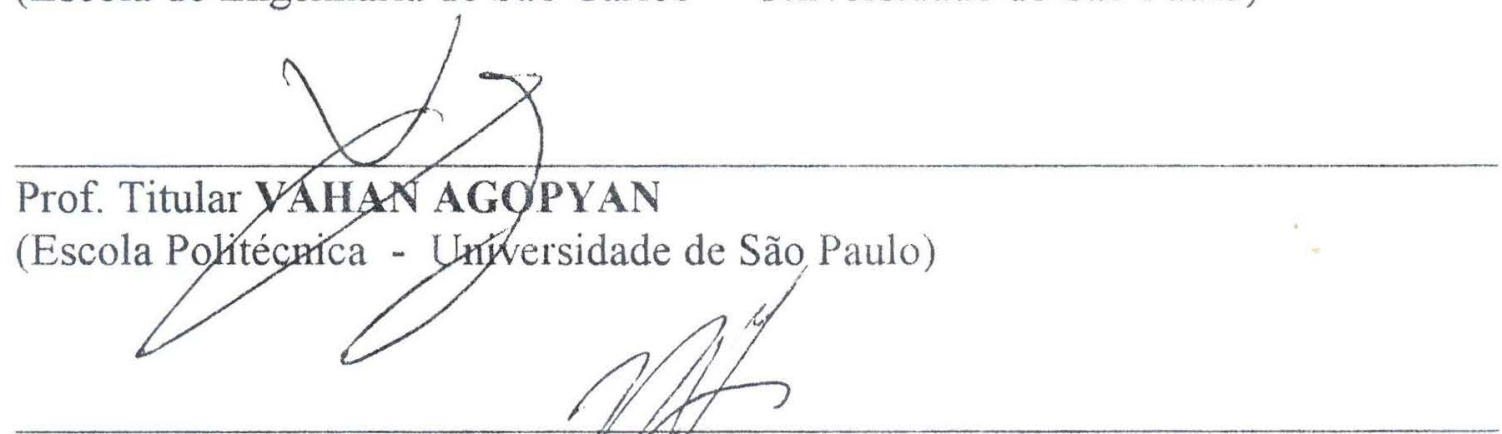

Prof. Doutor NEWTON DE OIAYEIRA PINTO JUNIOR

(Universidade Estadual de Campsinas - UNICAMP)

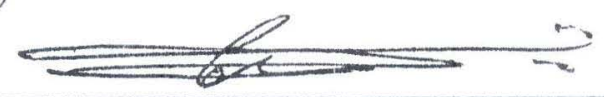

Prof. Titular CARLITO CALIL JUNIOR

Coordenador da Área de Engenharia de Estruturas

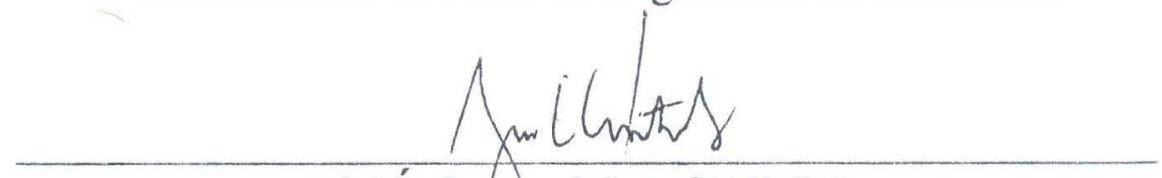

JOSÉ CARLOS A CINTRA

Presidente da Comissão de Pós-Graduação da EESC 
A os meus pais, Raul ef ul ia, e meus irmãos, $\mathrm{Cl}$ audia e Raul zinho, de todo meu coração.

A o J osé, com todo meu amore carinho, 


\section{AGRADECIMENTOS}

Passando por mais uma etapa da vida profissional, acima de tudo agradeço à Deus, pela força divina e poderosa, pela sabedoria e oportunidade, sem as quais eu não teria condições de chegar até aqui.

Ao meu orientador, que ao longo desses anos de trabalho, mostrou-se além de profissional extremamente competente, amigo, companheiro e grande incentivador.

Aos amigos: Paula, Larissa, Maria Cristina, Hélio, Carlos Henrique, Rogéria, Flávia e Adriana, pela amizade sincera e partilha das horas difíceis e alegres.

Ao tio João Carlos, tia Anita e família, pela hospedagem e apoio.

Aos professores: Flávio B. de Lima, Toshiaki Takeya, Roberto M. Gonçalves, João B. de Hanai, Mounir K. El Debs, Vaham Agopyan, Newton de O. Pinto Jr., Antonio de Figueiredo, Eloy F. Machado Jr., Sergio P. B. Proença, Laércio F. e Silva, Jorge Fortes, Marco A. Pastore, Magid E. Khouri, Artur Gonçalves, Roberto P. Gatsius, pela imensa cooperação e incentivo para execução deste trabalho.

Agradecimento muito especial aos técnicos do Laboratório de Estruturas: Amauri, Jorge, Mario, Mauri, Valdir, João, Reginaldo e ao Engenheiro Doutor Luiz Vicente Vareda, pela grandiosa colaboração, indispensável na realização da experimentação e aos funcionários dos Laboratórios de Construção Civil, Mecânica das Rochas e Madeiras e Estruturas de Madeira, pelo apoio e auxílio nos ensaios complementares.

Aos desenhistas Sylvia H. M. Villani e Francisco G. de Brito.

À bibliotecária Maria Nadir Minatel e à Eliana pela ajuda na elaboração e correção da bibliografia.

Ao pessoal da secretaria: Rosi, Marta, Toninho, Rui, Eli, Júnior e Massaki, pela cooperação.

Às secretárias da Faculdade de Engenharia de Barretos: Eremita, Renata, Marilda e Dina, pelo incentivo.

À toda minha família pelo grande incentivo à carreira que eu escolhi.

Aos demais colegas e funcionários da pós-graduação. Muito obrigada. 


\section{CRÉDITOS}

A elaboração desta pesquisa teve o apoio fundamental, tanto financeiro quanto técnico, de algumas instituições e empresas, abaixo relacionadas:

\section{Fundação Educacional de Barretos}

- Faculdade de Engenharia de Barretos

\section{Universidade de São Paulo}

- Escola de Engenharia de São Carlos

- Departamento de Engenharia de Estruturas

\section{CAPES}

- Coordenação de Aperfeiçoamento de Pessoal de Nível Superior, pela concessão de bolsa de estudos.

\section{FAPESP}

- Fundação de Amparo à Pesquisa do Estado de São Paulo, pelo Auxílio à Pesquisa correspondente ao processo 97/00932 - 6 .

\section{CAMARGO CORRÊA CIMENTOS S. A.,}

- Através dos engenheiros Cristovam S. C. Cunha e João Paulo Guimarães.

\section{REAX INDÚSTRIA E COMÉRCIO Ltda.,}

- Através do engenheiro Mauro M. Movikawa.

\section{BELGO-MINEIRA BEKAERT ARAMES FINOS Ltda.,}

- Através do Prof. Newton de Oliveira Pinto Júnior.

\section{VULKAN DO BRASIL Ltda., (HAREX)}

- Através do engenheiro Ferdinand M. G. Budweg 


\section{SUMÂRIO}

LISTA DE FIGURAS i

LISTA DE TABELAS v

LISTA DE SÍMBOLOS vi

RESUMO ix

ABSTRACT $x$

1 - INTRODUÇत̃ O 1

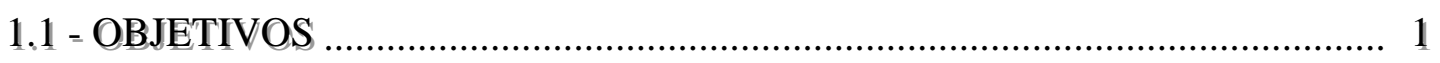

1.2 - APRESENTAÇÃ

1.3 = CONSIDERAÇÕES INICIAIS ......................................................... 3

2 - PROPRIEDADES DOS MATERIAIS 8

2.1 - CONSIDERAÇÕ ÖES INICIAIS .......................................................... 8

$2.2=$ CONCRETO DE ALTO DESEMPENHO ............................................. 8

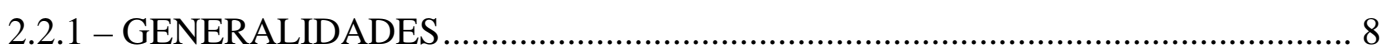

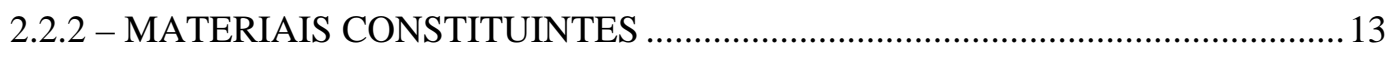

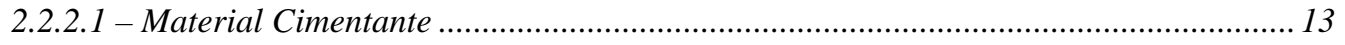

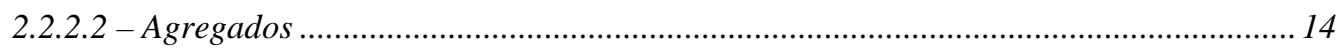

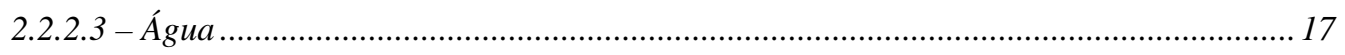

2.2.2.4 - Aditivos Químicos ............................................................................................. 17

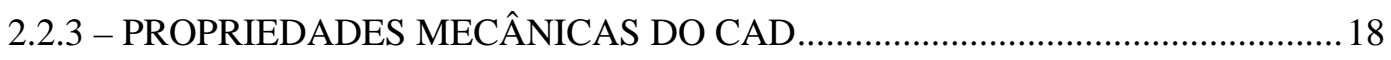

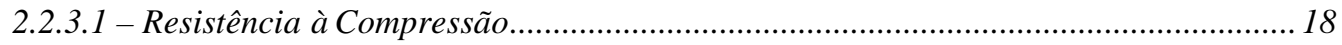

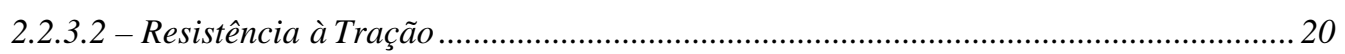

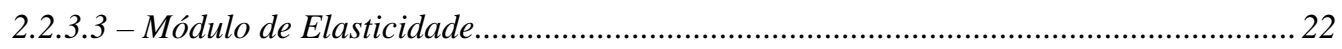

2.2.3.4 - Coeficiente de Poisson ............................................................................................... 23

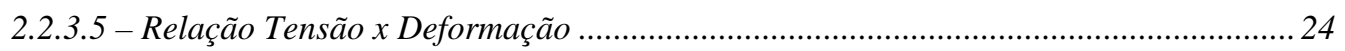


2.3.1 - DEFINIÇÃO

2.3.2 - PROPRIEDADES MECÂNICAS DO CONCRETO REFORÇADO COM FIBRAS

2.3.2.1 - Interação Fibra-Matriz.

2.3.2.2 - Eficiência do Reforço das Fibras.

2.3.2.3 - Comportamento do CRF submetido à Compressão ................................................... 35

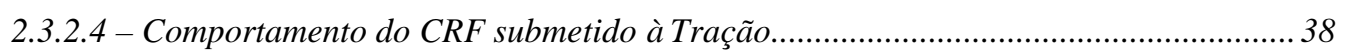

2.3.2.5 - Comportamento do CRF submetido à Flexão ........................................................... 40

2.3.3 - PREPARAÇÃO DO CONCRETO REFORÇADO COM FIBRAS .......................42

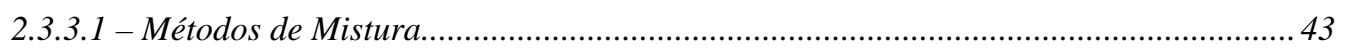

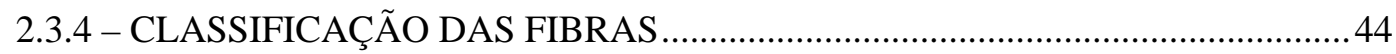

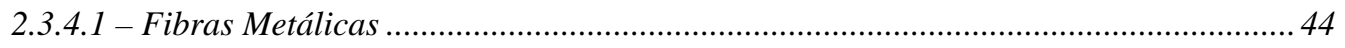

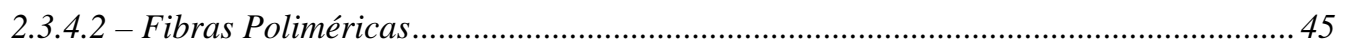

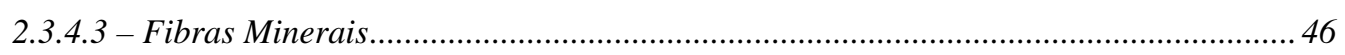

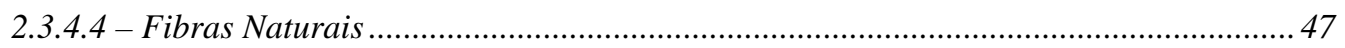

2.4 - CONSIDERAÇÕES FINAIS ........................................................... 47

3 - METODOLOGIA E DESCRIÇÃO DOS ENSAIOS

3.1 - CONSIDERAÇÕES INICIAIS .........................................................................4

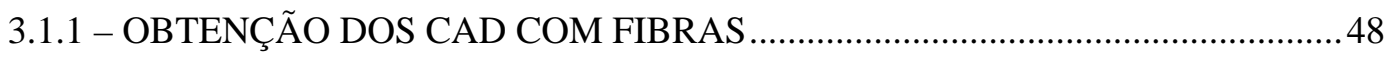

3.1.2 - EXPERIMENTAÇÃO COM MODELOS DE PILARES …..................................49

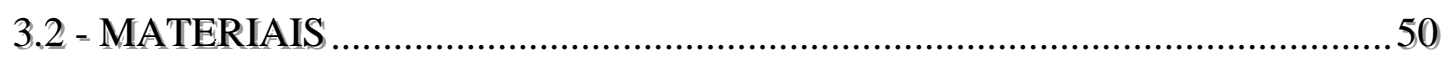

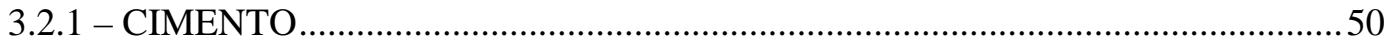

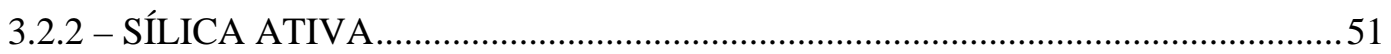

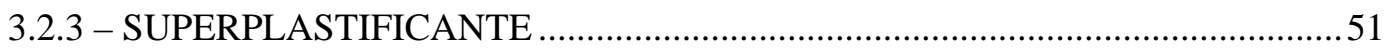

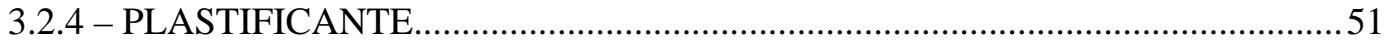

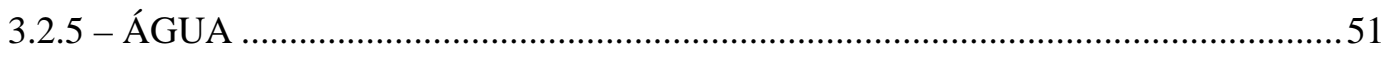

3.2.6 - AGREGADO MIÚDO ......................................................................................

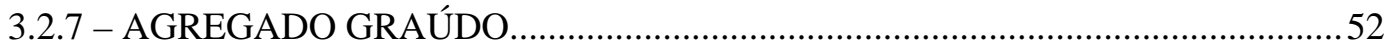

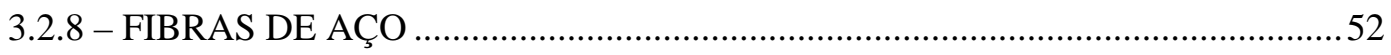


3.2.9 - FIBRAS DE POLIPROPILENO.

3.2.10 - DOSAGEM E PROCEDIMENTO DE MISTURA …..........................................53

3.2.11 - CARACTERIZAÇÃO DAS ARMADURAS ………………………...............56

3.3 - CARACTERÍSTICAS MECÂNICAS DOS CONCRETOS COM FIBRAS ... 57

3.3.1 - CONCRETO COM FIBRAS METÁLICAS.........................................................57

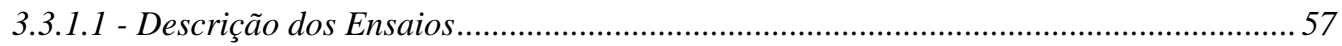

3.3.2 - CONCRETO COM FIBRAS DE POLIPROPILENO ….......................................59

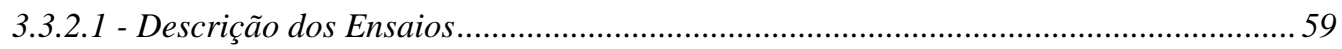

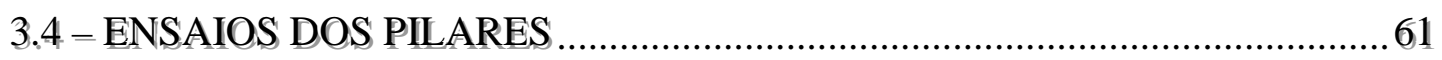

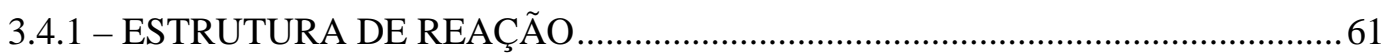

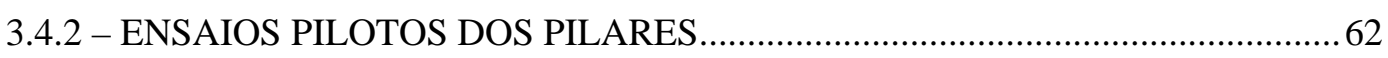

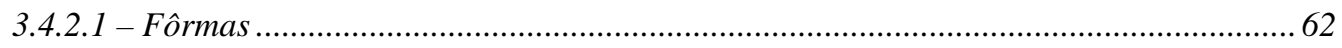

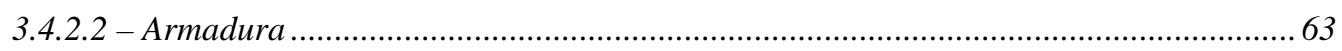

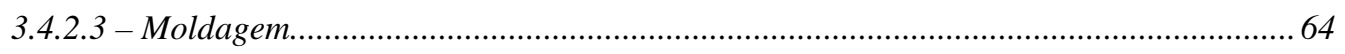

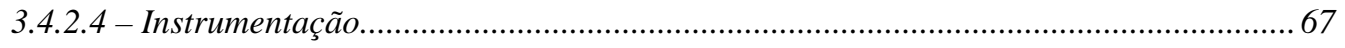

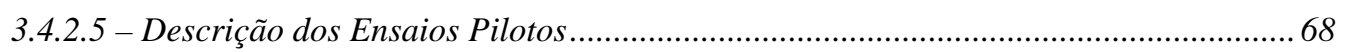

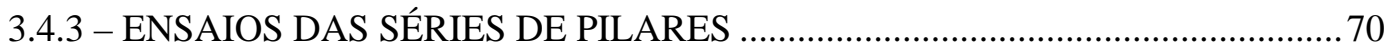

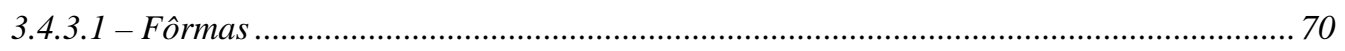

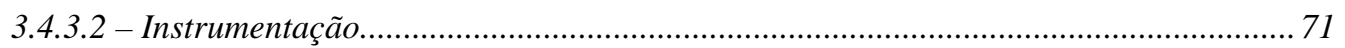

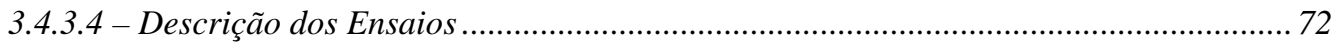

4 - RESULTADOS DOS ENSAIOS 80

4.1 - CONSIDERAÇÕES INICIAIS .......................................................................... 80

4.2 - CARACTERÍSTICAS MECÂNICAS DO CONCRETO COM FIBRAS .......80

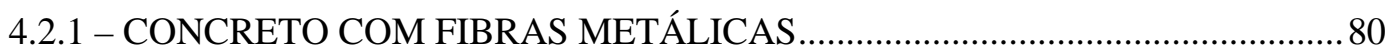

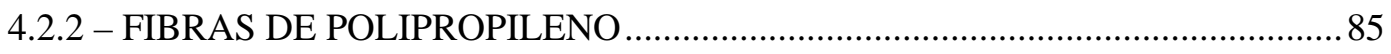

4.3 - ENSAIOS DOS MODELOS DE PILARES …............................................ 88

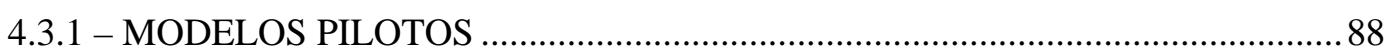

4.3.1.1 - Resultados Teóricos ........................................................................................... 91 
4.3.2 - SÉRIES DE PILARES ............................................................................. 93

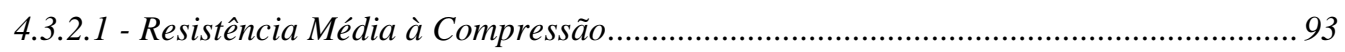

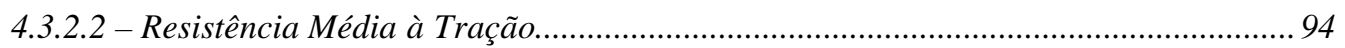

4.3.2.3 - Ensaios com Deformação Controlada dos Corpos-de-Prova..................................... 95

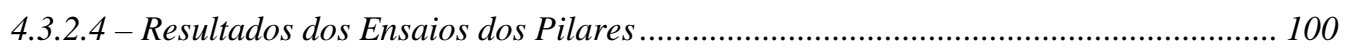

4.3.2.5 - Curvas Representativas dos Resultados................................................................. 103

4.4 = CONSIDERAÇÕES FINAIS ............................................................. 117

5-ANÁLISE DOS RESULTADOS 121

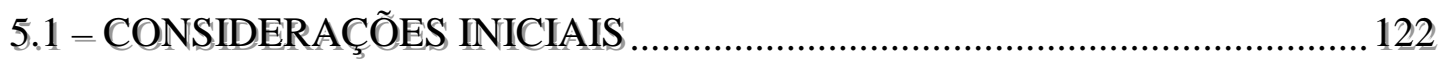

5.2 - ANÁLISE DOS RESULTADOS EXPERIMENTAIS ...................................123

5.3 - ANÁLISE DOS RESULTADOS EXPERIMENTAIS E DOS

NUMÉRICAMENTE OBTIDOS .............................................................................. 125

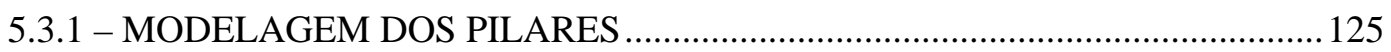

5.4 - COMPARAÇÃO COM OS RESULTADOS DE LIMA et al.(1997) ............ 132

5.5 - CONSIDERAÇÕ ÖES FINAIS ........................................................... 132

6- CONCLUSÃO 133

6.1 - CONTINUIDADE DA PESQUISA ………………………………….......... 136

7-BIBLIOGRAFIA 137

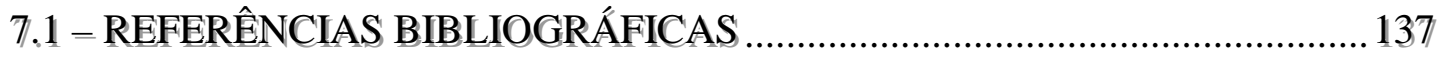

7.2 - BIBLIOGRAFIA COMPLEMENTAR …………………………………....... 143

APÊNDICE A

APÊNDICE B 


\section{LISTA DE FIGURAS}

FIGURA 1.1 - Destacamento do Cobrimento da Armadura

(LANGLOIS \& PAULTRE(1996))

FIGURA 2.1 - Representação da Zona de Transição e da Matriz da Pasta de Cimento no Concreto (MEHTA \& MONTEIRO(1994)). .11

FIGURA 2.2 - Curvas Tensão x Deformação Típicas de Concretos de Alto Desempenho (NEVILLE(1997)).

FIGURA 2.3 - Diagramas Tensão x Deformação de Cálculo Propostos por Zamarion (VASCONCELOS(1998)) .25

FIGURA 2.4 - Definição de $\alpha$ e $\beta$ (VASCONCELOS(1998)) .26

FIGURA 2.5 - Curvas Tensão x Deformação para Concretos com

Grandes e Pequenas Quantidades de Fibras

(BALAGURU \& SHAH(1992)) .30

FIGURA 2.6 - Interação Fibra-Matriz Com a Matriz Não Fissurada:

a)Descarregada; b)Submetida à Tração e

c)Submetida à Compressão. BALAGURU \& SHAH(1992). .33

FIGURA 2.7 - Comportamento Tensão x Deformação do CRF

na Compressão para Concretos de Convencionais

(BALAGURU \& SHAH(1992)) .36

FIGURA 2.8 - Comportamento Tensão x Deformação do CRF Submetido à

Compressão para Concreto de Alta Resistência

(BALAGURU \& SHAH(1992))

FIGURA 2.9 - Curvas Tensão x Deformação dos Compósitos de Matrizes Frágeis

Reforçados com Fibras em: a) Baixas Taxas;

b) Taxas Intermediárias; e c) Altas Taxas.

(BALAGURU \& SHAH(1992)) .39

FIGURA 2.10 - Curva Força x Deslocamento Típica para Compósitos com Fibras (BALAGURU \& SHAH(1992)) 
FIGURA 3.1 - Fibras Metálicas e Poliméricas .55

FIGURA 3.2 - Diagrama Tensão x Deformação para as Barras de 12,5mm .............56

FIGURA 3.3 - Diagrama Tensão x Deformação para as Barras de 6,3mm ...............57

FIGURA 3.4 - Aspecto do Concreto Durante a Mistura e Lançamento ....................58

FIGURA 3.5 - Moldagem dos Corpos-de-Prova......................................................58

FIGURA 3.6 - Concreto com Adição de Fibras de Polipropileno ............................60

FIGURA 3.7 - Pórtico de Reação Instalado no Galpão de Ensaios do Laboratório .61

FIGURA 3.8 - Fôrma Utilizada para Moldagem dos Pilares Pilotos ........................62

FIGURA 3.9 - Armadura de Fretagem e Estribos ao longo do Pilar ........................63

FIGURA 3.10 - Disposição das Armaduras com Espaçadores nas Fôrmas...............64

FIGURA 3.11 - Concreto com Fibras de Polipropileno

$0,50 \%$ de taxa volumétrica) ....................................................64

FIGURA 3.12 - Moldagem do Pilar Piloto 1 .........................................................65

FIGURA 3.13 - Retirada do Concreto com Fibras Metálicas da Betoneira ..............65

FIGURA 3.14 - Moldagem do Pilar Piloto 2 ….....................................................66

FIGURA 3.15 - Concreto para Moldagem do Pilar 3 .............................................67

FIGURA 3.16 - Configuração Final da Fôrma.......................................................67

FIGURA 3.17 - Instrumentação dos Pilares Pilotos .................................................68

FIGURA 3.18 - Fôrma Utilizada para Moldagem das Séries de Pilares....................71

FIGURA 3.19 - Instrumentação das Séries de Pilares ................................................72

FIGURA 4.1 - Comportamento do Concreto da Série A .........................................81

FIGURA 4.2 - Comportamento do Concreto da Série B..........................................82

FIGURA 4.3 - Comportamento do Concreto da Série C...........................................83

FIGURA 4.4 - Comportamento do Concreto da Série D ...........................................84

FIGURA 4.5 - Comportamento do Concreto da Série E...........................................85

FIGURA 4.6 - Comportamento do Concreto da Série F ...........................................86

FIGURA 4.7 - Comportamento do Concreto da Série G ..........................................87

FIGURA 4.8 - Diagramas Tensão x Deformação para o Aço - Piloto 1....................89

FIGURA 4.9 - Diagramas Tensão x Deformação para o Concreto - Piloto 1 ............89

FIGURA 4.10 - Primeiras Fissuras - Piloto 2 ….......................................................90

FIGURA 4.11 - Forma de Ruptura do Pilar Piloto 2 ............................................... 90 
FIGURA 4.12 - Diagramas Tensão x Deformação para o Aço - Piloto 2.................91

FIGURA 4.13 - Diagramas Tensão x Deformação para o Concreto - Piloto 2 .........91

FIGURA 4.14 - Ruptura do Pilar Piloto 3 …...........................................................92

FIGURA 4.15 - Diagramas Tensão x Deformação para o Aço - Piloto 3 ..................93

FIGURA 4.16 - Diagramas Tensão x Deformação para o Concreto - Piloto 3 .........93

FIGURA 4.17 - Diagramas Tensão x Deformação dos Concretos dos 3 Pilares

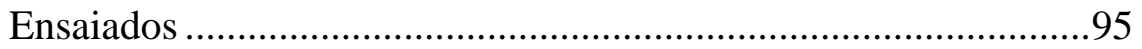

FIGURA 4.18 - Diagramas Tensão x Deformação dos Pilares................................95

FIGURA 4.19 - Curvas Força x Deslocamentos P1a05, P1a10 e P1a15 ................ 100

FIGURA 4.20 - Curvas Força x Deslocamentos P2a05, P2a10 e P2a15 ................ 100

FIGURA 4.21 - Curvas Força x Deslocamentos P3a05, P3a10 e P3a15 ................ 101

FIGURA 4.22 - Curvas Força x Deslocamentos P4a05, P4a10 e P4a15 ................. 101

FIGURA 4.23 - Curvas Força x Deslocamentos P3p10 ......................................... 102

FIGURA 4.24 - Comportamento das Forças Últimas com as Taxas de Fibras....... 104

FIGURA 4.25 - Comportamento das Deformações para as Forças Últimas com as Taxas de Fibras 105

FIGURA 4.26 - Comportamento das Deformações à 80\% das Forças Últimas com as Taxas de Fibras ................................................................ 105

FIGURA 4.27 - Diagramas Força x Deformação da série P1a15 ........................... 107

FIGURA 4.28 - Diagramas Força x Deformação da série P1a10 ........................... 108

FIGURA 4.29 - Diagramas Força x Deformação da série P1a05 ........................... 109

FIGURA 4.30 - Diagramas Força x Deformação da série P2a15 .......................... 110

FIGURA 4.31 - Diagramas Força x Deformação da série P2a10 .......................... 111

FIGURA 4.32 - Diagramas Força x Deformação da série P2a05 .......................... 112

FIGURA 4.33 - Diagramas Força x Deformação da série P3a15 ............................ 113

FIGURA 4.34 - Diagramas Força x Deformação da série P3a10 ........................... 114

FIGURA 4.35 - Diagramas Força x Deformação da série P3a05 ........................... 115

FIGURA 4.36 - Diagramas Força x Deformação da série P4a15 ............................ 116

FIGURA 4.37 - Diagramas Força x Deformação da série P4a10 ........................... 117

FIGURA 4.38 - Diagramas Força x Deformação da série P4a05 ........................... 118

FIGURA 4.39 - Diagramas Força x Deformação da série P3p10 ............................ 119 
FIGURA 5.1 - Discretização dos Pilares conforme o Espaçamento

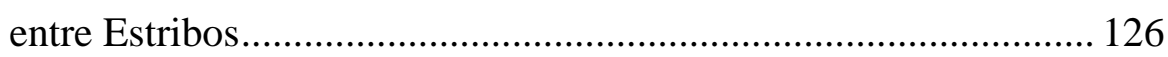

FIGURA 5.2 - Distribuição das Tensões - Ilustração Geral................................... 126

FIGURA 5.3 - Discretização da Armadura ......................................................... 127

FIGURA 5.4 - Análise Experimental e Numérica da Série P1a05 ......................... 128

FIGURA 5.5 - Análise Experimental e Numérica da Série P1a10......................... 128

FIGURA 5.6 - Análise Experimental e Numérica da Série P1a15......................... 128

FIGURA 5.7 - Análise Experimental e Numérica da Série P2a05 ......................... 129

FIGURA 5.8 - Análise Experimental e Numérica da Série P2a10......................... 129

FIGURA 5.9 - Análise Experimental e Numérica da Série P2a15 ......................... 129

FIGURA 5.10 - Análise Experimental e Numérica da Série P3a05........................ 130

FIGURA 5.11 - Análise Experimental e Numérica da Série P3a10....................... 130

FIGURA 5.12 - Análise Experimental e Numérica da Série P3a15....................... 130

FIGURA 5.13 - Análise Experimental e Numérica da Série P4a05 ........................ 131

FIGURA 5.14 - Análise Experimental e Numérica da Série P4a10........................ 131

FIGURA 5.15 - Análise Experimental e Numérica da Série P4a15....................... 131 


\section{LISTA DE TABELAS}

Tabela 2.1 - Valores dos Coeficientes proposto por Diniz

(VASCONCELOS(1998))

Tabela 2.2 - Propriedades das Fibras (BENTUR \& MINDESS(1990))....

Tabela 3.1 - Fibras Utilizadas nos Ensaios Preliminares .52

Tabela 3.2 - Fibras Utilizadas nos Ensaios Preliminares .53

Tabela 3.3 - Traço Inicial Utilizado nos Ensaios Preliminares .................................54

Tabela 3.4 - Traço Modificado Utilizado nos Ensaios ..............................................54

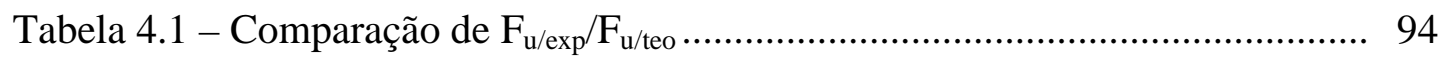

Tabela 4.2 - Resistências Médias à Compressão das Séries de Pilares.................. 97

Tabela 4.3 - Resistências Médias à Tração das Séries de Pilares............................ 98

Tabela 4.4 - Ensaios com Deformação Controlada .............................................. 99

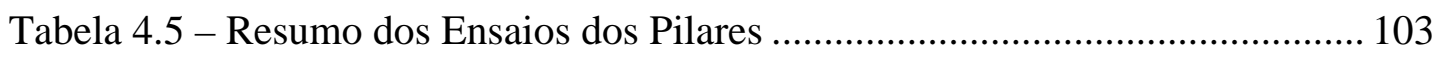

Tabela 5.1 - Análise Teórica dos Resultados dos Ensaios ..................................... 122

Tabela 5.2 - Análise Teórica Segundo COLLINS et al.(1993) .............................. 124

Tabela 5.3 - Resultados dos ensaios feitos por LIMA et al.(1997) ....................... 131 


\section{LISTA DE SÍMBOLOS}
$\mathrm{A}_{\mathrm{c}} \quad$ - Área de concreto da seção transversal do pilar
$\mathrm{A}_{\mathrm{cn}} \quad$ - Área de concreto da seção transversal do núcleo do pilar
A $\quad$ - Área da seção transversal das barras da armadura longitudinal
b - Largura da seção transversal do pilar
c - Cobrimento da armadura
C - Coeficiente de ajuste da resistência do concreto
CH - Hidróxido de Cálcio
CSH - Silicato de cálcio hidratado
CSAH - Etringita (composto cristalino)
$\mathrm{C}_{3} \mathrm{~A} \quad-$ Aluminato tricálcico
d $\quad$ - Diâmetro da seção transversal da fibra
$\mathrm{E}_{\mathrm{c}} \quad$ - Módulo de deformação longitudinal do concreto
$\mathrm{E}_{\mathrm{ci}} \quad$ - Módulo de deformação longitudinal do concreto na idade de 28 dias
$\mathrm{E}_{\mathrm{y}} \quad$ - Módulo de deformação longitudinal do aço
$\mathrm{F}_{\mathrm{u}} \quad$ - Força última do pilar

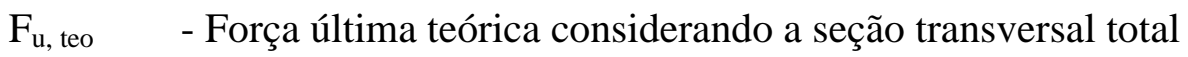
$\mathrm{F}_{\text {un, teo }} \quad$ - Força última teórica considerando-se o núcleo da seção
$\mathrm{F}_{\mathrm{u}, \exp } \quad$ - Força última experimental
$0,8 \mathrm{~F}_{\mathrm{u}, \exp }$ - Força experimental à $80 \%$ da força última
$\mathrm{f}_{\mathrm{c}} \quad$ - Resistência à compressão do concreto
$\mathrm{f}_{\mathrm{c} \text {,laboratório }}$ - Resistência à compressão do concreto medida em corpos-de-prova moldados durante a concretagem (Boletim 197 do CEB-FIP(1990))
$\mathrm{f}_{\mathrm{c}, \text { obra }} \quad$ - Resistência à compressão do concreto medida em testemunhos extraídos da estrutura (Boletim 197 do CEB-FIP(1990))
$\mathrm{f}_{\mathrm{c}}{ }$ - Resistência à compressão do concreto segundo o ACI 318/89
$\mathrm{f}_{\mathrm{cd}} \quad-$ Valor de cálculo da resistência à compressão do concreto
$\mathrm{f}_{\mathrm{ck}} \quad-$ Resistência característica à compressão do concreto
$\mathrm{f}_{\mathrm{ct}} \quad$ - Resistência à tração direta 
$\mathrm{f}_{\mathrm{ctk}} \quad-$ Resistência característica à tração do concreto

$\mathrm{f}_{\mathrm{ctm}} \quad-$ Resistência média à tração do concreto

$\mathrm{f}_{\mathrm{ct}, \mathrm{sp}} \quad$ - Resistência à tração indireta

$\mathrm{f}_{\mathrm{ct}, \mathrm{f}} \quad$ - Resistência à tração na flexão

$\mathrm{f}_{\mathrm{y}} \quad$ - Resistência de escoamento do aço à tração

$\mathrm{f}_{\mathrm{yk}} \quad-$ Valor característico da resistência de escoamento do aço

h $\quad$ - altura da seção transversal do pilar

L - Comprimento da fibra

L/d - Relação de aspecto da fibra

$\mathrm{k}_{3} \quad$ - Coeficiente de ajuste da resistência do concreto segundo COLLINS et al.(1993)

$\alpha \quad$ - Coeficiente redutor da resistência de cálculo do concreto usado para o cálculo da base do retângulo equivalente ao diagrama de distribuição de tensões da seção transversal do concreto (VASCONCELOS(1998))

$\beta \quad$ - Fração da profundidade da Linha Neutra, usado para o cálculo da altura do retângulo equivalente ao diagrama de distribuição de tensões da seção transversal do concreto (VASCONCELOS(1998))

$\varepsilon_{\mathrm{c}} \quad$ - Deformação específica de compressão do concreto

$\varepsilon_{\mathrm{cu}} \quad-$ Valor último da deformação específica do concreto comprimido

$\varepsilon_{0,8 \mathrm{Fu}, \exp }$ - Deformação equivalente à força experimental à $80 \%$ da força última

$\varepsilon_{\mathrm{y}} \quad$ - Deformação específica de escoamento do aço à tração

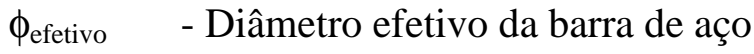

$\phi_{\text {nominal }} \quad$ - Diâmetro nominal da barra de aço

$\phi \quad$ - Diâmetro da barra de aço que compõe a armadura

$\gamma_{\mathrm{m}} \quad$ - Coeficiente de minoração da resistência dos materiais

$\gamma_{c} \quad$ - Coeficiente de minoração da resistência do concreto

$\gamma_{\text {hsc }} \quad$ - Coeficiente de majoração do coeficiente $\gamma_{c}$, proposto pelo Boletim 228 do CEB-FIP(1995)

$\rho_{\ell} \quad$ - Taxa geométrica de armadura longitudinal

$\rho_{\mathrm{s}} \quad$ - Taxa volumétrica de armadura 
$\rho_{\mathrm{w}} \quad$ - Taxa volumétrica de armadura transversal considerando-se a seção do núcleo

$\sigma_{\mathrm{c}} \quad$ - Tensão normal de compressão no concreto

$\bar{\sigma}_{\mathrm{c}} \quad$ - Índice de tenacidade obtido em ensaios de corpos-de-prova segundo THE JAPAN SOCIETY OF CIVIL ENGINEERS(1994)

$\sigma_{\mathrm{cd}} \quad$ - Valor de cálculo da tensão normal de compressão no concreto

v $\quad$ - Coeficiente de Poisson 


\section{RESUMO}

\section{GUIMARÃES, A.E.P.(1999). Análise experimental de pilares de concreto de alta} resistência com adição de fibras metálicas submetidos à compressão centrada. São Carlos. Tese de Doutorado - Escola de Engenharia de São Carlos, Universidade de São Paulo.

O Concreto de Alto Desempenho (CAD) tem sido extensivamente estudado em muitos centros de pesquisas porque seu uso tem aumentado de maneira significativa na construção civil. Mas a fragilidade deste material, quando a resistência à compressão é alta, tem levado os pesquisadores a estudar maneiras de diminuir esta característica, como por exemplo aumentando as taxas de armaduras transversal e/ou longitudinal dos elementos estruturais em concreto armado.

Este trabalho trata do uso de fibras adicionadas ao concreto para uso em pilares submetidos à compressão, visando dar subsídios técnicos em outra maneira de se obter ductilidade em elementos de concreto de alta resistência, utilizando taxas usuais de armadura transversal.

Apresenta-se um estudo experimental sobre pilares em concreto de alto desempenho com adição de fibras metálicas, com seção transversal de $200 \mathrm{~mm} \mathrm{x}$ $200 \mathrm{~mm}$ e altura de $1200 \mathrm{~mm}$, submetidos à compressão centrada, onde o concreto apresenta uma resistência média à compressão de $80 \mathrm{MPa}$. As taxas volumétricas de fibras foram de $0,25 \% ; 0,50 \%, 0,75 \%$ e $1,00 \%$, adotaram-se taxas volumétricas de estribos de $0,55 \%, 0,82 \%$ e $1,63 \%$ e a taxa geométrica de armadura longitudinal de $2,41 \%$ permaneceu a mesma para todos os pilares. Percebeu-se que a ruptura dos pilares foi mais dúctil quanto maior era a quantidade de fibras adicionadas ao concreto.

$\mathrm{Na}$ análise teórica feita com os modelos, constatou-se que somente a seção transversal do núcleo, ou seja, aquela delimitada pelos eixos dos estribos, contribui para a resistência dos pilares, para pequenas taxas de fibras adicionadas ao concreto.

Palavras Chaves: Concreto de alta resistência; Concreto com fibras; Fibras metálicas; Pilares; Experimentação. 


\title{
ABSTRACT
}

\author{
GUIMARÃES, A.E.P.(1999). Experimental analysis of columns in high strength \\ concrete with steel fibres under compression load. São Carlos. Doctorate \\ Thesis. Engineering School of São Carlos, University of São Paulo.
}

High Performance Concrete (HPC) has been studied extensively at many centres of research, because of its increasing use in reinforced concrete buildings. Since HPC is a brittle material, mainly when its strength is high (HSC), studies have been done to increase its ductility. Increases in longitudinal and/or transverse steel ratios can improve the ductility of HPC elements.

This work shows a research about concrete with steel fibres for columns under compression load, in another way to obtain ductility in high strength concrete elements with usual stirrups ratio.

It was made a experimental studied about columns in HSC with steel fibres addition, with $20 \mathrm{~cm} \times 20 \mathrm{~cm}$ of cross section and $120 \mathrm{~cm}$ high, under compression load.

The concrete strength was about $80 \mathrm{MPa}$, the volumetric fibres ratio were $0,25 \%, 0,50 \%, 0,75 \%$ and $1,00 \%$, the stirrups ratio were $0,55 \%, 0,82 \%$ and $1,63 \%$ and the longitudinal bars ratio was constant for all columns. It was noted that the columns failure was more ductile when the fibres ratio was higher.

It was verified on theoretical analyses made with the models that only the cross-sectional core, it means the section delimited by the stirrups, effectively contributed to the load capacity of the columns.

Keywords: High performance concrete; Fibres concrete; Steel fibres; Columns; Experimental analyses. 


\section{1 - OBJETIVOS}

O intuito desta pesquisa foi estudar o comportamento dos pilares de concreto de alto desempenho com adição de fibras metálicas quanto a sua ductilidade, quando os mesmos estão submetidos à compressão centrada. Para este caso, o atributo principal do concreto de alto desempenho foi a alta resistência, com resistência média à compressão prevista para 15 dias, em torno de $80 \mathrm{MPa}$, obtida com adição de sílica ativa e aditivos superplastificantes.

As quantidades de fibras utilizadas foram variadas, sem no entanto ultrapassar as proporções limites indicadas pela literatura técnica, para que o compósito não perdesse as características do concreto com fibras usuais. Outra variação feita nesta pesquisa foi a taxa de armadura transversal, para que pudesse ser estudada a influência das fibras no aumento de ductilidade dada pelos estribos e quanto ao destacamento do cobrimento antes da ruptura do núcleo dos pilares.

Uma das preocupações foi de se trabalhar com os elementos estruturais (pilares) o mais próximo possível das dimensões usuais dos edifícios, assim optando pelas medidas de $20 \mathrm{~cm}$ x $20 \mathrm{~cm}$ para a seção transversal. A altura dos modelos foi fixada em $120 \mathrm{~cm}$ para que não houvesse o efeito de flambagem, visto que não era objeto de estudo para este trabalho. Deste modo, a comparação dos resultados obtidos com a de outros pesquisadores também se tornou viável. 
Em princípio não foram estudadas outras formas de seções transversais, tais como circulares e retangulares, nem pilares confinados por tubos metálicos, que representam uma possível continuidade desta pesquisa.

O trabalho se torna de extrema importância para o meio técnico como uma nova alternativa para construção de pilares de edifícios em concreto de alto desempenho, baseado nos resultados dos ensaios e na bibliografia, referenciada e indicada.

\section{2 - APRESENTAÇÃO}

Esta tese foi estruturada em 7 capítulos e dois apêndices. O primeiro capítulo traz uma introdução ao trabalho, com o objetivo da pesquisa e uma revisão bibliográfica sobre os trabalhos desenvolvidos por outros pesquisadores sobre o estudo do comportamento de pilares de concreto de alta resistência com adição de fibras.

No segundo capítulo descrevem-se os materiais envolvidos na pesquisa, concreto de alto desempenho e concreto com adição de fibras, analisando suas características e comportamentos mecânicos.

O terceiro capítulo mostra a metodologia empregada e a descrição dos ensaios experimentais realizados na primeira fase do trabalho de pesquisa, onde se procurou estudar o comportamento do material concreto de alta resistência com adição de fibras metálicas e de polipropileno quanto às características de resistência à compressão, resistência à tração em ensaios de compressão diametral, e módulo de elasticidade. Na segunda etapa da pesquisa se fizeram os ensaios principais com os modelos de pilares, visando observar as deformações dos elementos, nas direções longitudinal e transversal, para que fosse analisado o comportamento do concreto com fibras dos pilares quanto às deformações à tração e à compressão. Os resultados dos ensaios, tanto da primeira quanto da segunda fase do trabalho, são mostrados no quarto capítulo, com as observações e conclusões pertinentes a eles.

O quinto capítulo traz uma análise dos resultados experimentais obtidos nesta pesquisa, em comparação com resultados teóricos obtidos com auxílio de análise numérica feita utilizando-se o programa ANSYS(1997), e outra comparação com os resultados experimentais obtidos por LIMA(1997). 
As conclusões do trabalho são relatadas no sexto capítulo, com indicações de continuidade da pesquisa, e a bibliografia, tanto referenciada quanto indicada, estão no sétimo capítulo.

O Apêndice A mostra os resultados dos ensaios dos corpos-de-prova de $100 \mathrm{~mm}$ x 200mm, submetidos à compressão com deformação controlada, feitos no Laboratório de Geotecnia da EESC - USP, e o Apêndice B mostra fotografias selecionadas dos ensaios dos pilares.

\section{3 - CONSIDERAÇÕES INICIAIS}

Nesta primeira etapa da revisão, destacam-se o desenvolvimento dos trabalhos em concreto com fibras.

Segundo BENTUR et al.(1990), a utilização das fibras como reforço para o concreto ocorreu em duas frentes distintas: nas peças delgadas, na busca de compósitos substitutivos do cimento-amianto (com volumes acima de 5\%, para melhorar a tenacidade, a durabilidade e a resistência da matriz de cimento) e em peças de concreto, como armadura secundária (com volumes reduzidos, até 2\%), para melhorar a tenacidade, o controle da fissuração induzida e o desempenho sob ações dinâmicas. Destaca-se, ainda, a importância das pesquisas com fibras em concretos de alta resistência.

Nos concretos produzidos com pequenos volumes de fibras, a primeira evidência da influência destas, nos elementos submetidos à esforços de tração ocorre somente após a ruptura da matriz, cuja resistência não se altera.

Nos compósitos produzidos com técnicas especiais, com volumes de fibras de até $15 \%$, ao contrário, altera-se a natureza da matriz, aumentando muito os valores do módulo de deformação longitudinal e da resistência à tração. Seria uma nova classe de materiais, cujo comportamento à flexão se aproxima do comportamento das vigas de aço.

$\mathrm{O}$ acréscimo da resistência à tração do concreto com a adição de fibras é eventual, ocorrendo normalmente quando o volume de fibras é elevado, de modo a viabilizar a configuração da múltipla fissuração. A tenacidade, ao contrário, sempre aumenta, pois a energia necessária para a ruptura é dissipada na deformação da fibra, na separação da interface fibra-matriz e no atrito provocado pelo escorregamento da 
fibra. O aumento da ductilidade está associado à fissuração múltipla da matriz, à ruptura da interface fibra-matriz e ao seu posterior arrancamento.

A recomendação do ACI 544 - 3R(1993) sobre a utilização de fibras é que esta deve ser criteriosa e cautelosa: em aplicações estruturais, devem ser usadas somente como material suplementar, para inibir a fissuração, melhorar a resistência ao impacto ou às ações dinâmicas e impedir a desintegração do material. Para solicitação de flexão ou tração, a armadura convencional deve ser capaz de resistir a todas as ações aplicadas.

Segundo SHAH(1996), a adição de fibras pode alterar substancialmente a fragilidade do concreto. A armadura é espaçada ao nível de milímetros e consequentemente ela não interage com as fissuras. Deste modo o concreto não ganha resistência à tração, mas a armadura pode controlar as aberturas das fissuras. As fibras, se espaçadas ao nível de micrometros quando adicionadas ao compósito, podem interagir com as fissuras, retardando o início de sua abertura e aumentando a resistência à tração do concreto, melhorando o comportamento do material.

AGOPYAN(1991) mostra uma pesquisa sobre concreto com adição de fibras vegetais, sendo algumas delas juta, sisal e coco, na construção civil, para fabricação de painéis de vedação, para obras públicas.

Alguns testes em modelos em escala natural têm mostrado que fibras de aço são efetivas como suplemento ou em substituição aos estribos em vigas como consta no ACI 544.4R-88 e em FURLAN(1995), e embora não seja uma prática aceitável no presente, outros testes têm mostrado que as fibras de aço em combinação com as armaduras podem aumentar a capacidade resistente de vigas de concreto armado.

ZAMBRANA VARGAS(1997) estudou o uso de fibras metálicas em concretos convencional e de alta resistência para construção de lajes-cogumelo visando analisar o comportamento destes elementos quanto à punção.

As fibras hoje tem sido muito empregadas na construção de túneis, segundo consta no trabalho de FIGUEIREDO(1997), que descreve a utilização de fibras de aço, alterando o sistema tradicional de construção de túneis para outro sistema denominado NATM.

A utilização de fibras tem aumentado na construção de pavimentos de rodovias (ACI 544.4R-88) e aqui no Brasil, em aplicação nos pisos industriais, como 
armadura secundária e no controle da fissuração, como consta em PINTO Jr. \& BINA(1996), PINTO Jr. \& MORAES(1996), REGATTIERI et al.(1996) e SILVA et al.(1996).

Foram citados até agora alguns trabalhos de pesquisa desenvolvidos com a adição de fibras ao concreto para execução de estruturas diversas. Agora descrevemse alguns trabalhos encontrados com respeito ao estudo de pilares.

Nos grandes centros urbanos onde o poder aquisitivo da população é maior, o número de veículos na região aumenta e com isto há necessidade de mais espaço nas garagens. Este problema econômico exige solução arquitetônica com mais espaços livres e, por conseguinte, indica que na solução estrutural, os pilares sejam mais esbeltos e o espaço entre eles seja maior.

Os pilares construídos com Concreto de Alto Desempenho (CAD) vieram solucionar esta questão, com a execução de elementos submetidos à compressão, de dimensões menores. Para vigas e lajes, a utilização do CAD é vantajosa quando a questão é a durabilidade da estrutura, pois são peças estruturais solicitadas também à tensões de tração.

Mas aumentando a resistência do concreto, a ductilidade do material diminui, tornando frágil a sua ruptura.

No CAR a curva tensão x deformação é mais linear, e a deformação para a resistência máxima é maior quando comparada com a que ocorre para os concretos de resistência convencional. Em LIMA(1997) pode-se encontrar uma vasta revisão bibliográfica sobre os trabalhos que vem sendo desenvolvidos sobre pilares de CAR, com respeito a tenacidade, ductilidade e confinamento do núcleo sendo que no Brasil, um dos trabalhos pioneiros foi o de AGOSTINI(1992), analisando pilares com armadura helicoidal, submetidos à compressão centrada e flexão normal composta.

O comportamento de pilares em CAD, segundo PAULTRE et al.(1996), é caracterizado pela ruptura rápida e repentina do cobrimento de concreto. Contribuindo para o fenômeno estão a fragilidade na interface entre o concreto confinado e o não confinado (cobrimento), criado pela armadura. Acredita-se que a adição de fibras à mistura de concreto de alta resistência pode prevenir a separação prematura do cobrimento de concreto. Deste modo o efeito das fibras casualmente 
posicionadas na massa de concreto, atrasa esta ruptura antes do pilar atingir o colapso. O destacamento prematuro do cobrimento de concreto nos pilares em CAD é observado quando concretos com resistências superiores - $80 \mathrm{MPa}$ ou mais - são usados.

A figura 1.1 ilustra a flambagem que a chapa de concreto que constitui o cobrimento de armadura sofre quando da aplicação da força nos pilares, que é reportado em LANGLOIS \& PAULTRE(1996). Com um mínimo de adição de fibras ao concreto, esta flambagem do cobrimento não ocorre mais, visto que as fibras “costuram" o cobrimento junto ao núcleo, mas, sem fazer com que a seção transversal total seja mais resistente à força aplicada no pilar.

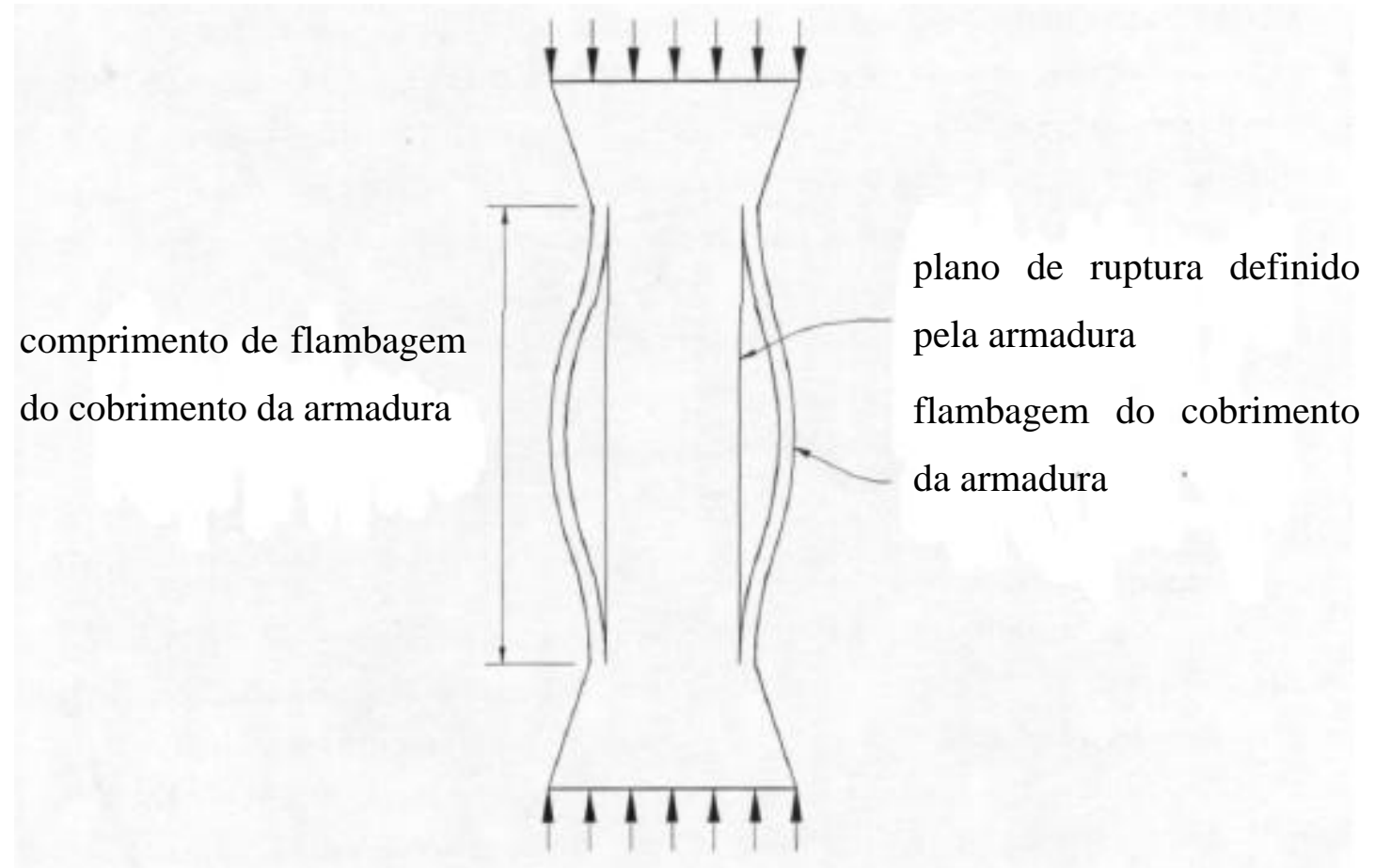

FIGURA 1.1 - Destacamento do Cobrimento da Armadura

(LANGLOIS \& PAULTRE(1996))

O concreto de alta resistência com adição de fibras (CARF), como foi citado, é usado principalmente para recapeamento de pavimentos, de rodovias e pistas de aeroportos, para aumentar a resistência à flexão e à fadiga, assim como também para aumentar a resistência do concreto a meios agressivos e diminuir as aberturas das fissuras. 
Esta qualidade das fibras em controlar a fissuração pode ser usada para impedir o destacamento prematuro do cobrimento dos pilares carregados, enquanto aumenta a ductilidade e resistência ao meio agressivo. $\mathrm{O}$ aumento da ductilidade de elementos estruturais é uma qualidade muito procurada em projetos de estruturas para suportar ações sísmicas.

Os trabalhos desenvolvidos no Canadá visam principalmente a resistência do concreto à aplicações de carregamento cíclico, como é reportado em LANGLOIS \& PAULTRE(1996) e LEVESQUE(1998), onde se fizeram estudos da aplicabilidade do concreto com fibras metálicas em pilares sob a aplicação de força centrada e cíclica, visando aumento do grau de confinamento do núcleo dos elementos, dado pelos estribos, e a ductilidade sob a ação de carregamento cíclico, sendo que a conclusão obtida pelos pesquisadores foi de que as fibras aumentam o efeito de confinamento, desde que este efeito seja dado principalmente pelo arranjo dos estribos. Esta conclusão foi discutida pessoalmente com o Professor Patrick Paultre, da Université de Sherbrooke, quando de sua visita ao Departamento de Engenharia de Estruturas, em março de 1998.

A adição de fibras no concreto visa aumentar a tenacidade do material e com isso aumentar a ductilidade das estruturas, proporcionando a elas maiores deformações quando da aplicação de ações.

Os edifícios altos são imprescindíveis, tendo em vista a urbanização e o crescimento populacional, e eles podem assumir formas variadas, que dependem somente da criatividade do engenheiro de estruturas. Cada vez mais o CAR vem sendo usado para construção dessas estruturas, por isso a preocupação dos pesquisadores quanto à sua fragilidade. 


\section{1 - CONSIDERAÇÕES INICIAIS}

Este capítulo trata de alguns aspectos ligados aos materiais envolvidos na obtenção do concreto usado nos pilares que foram estudados para esta pesquisa, ou seja, concreto de alto desempenho e concreto com adição de fibras. Algumas propriedades de cada material serão aqui discutidas separadamente.

\section{2- CONCRETO DE ALTO DESEMPENHO}

\subsection{1 - GENERALIDADES}

O CAD tem um desempenho melhor do que o concreto convencional quanto às suas propriedades mecânicas, tais como: durabilidade, impermeabilidade, resistência à abrasão, resistência característica à compressão e etc.. O concreto que apresentar melhor comportamento quanto a qualquer uma destas propriedades citadas em relação ao concreto convencional, é chamado de Concreto de Alto Desempenho. O Concreto de Alta Resistência é um CAD onde a principal característica é o seu alto desempenho mecânico quanto à resistência característica à compressão. 
Até há algum tempo, segundo AÏ TCIN et al.(1993), referia-se aos concretos com resistências superiores às usuais como Concretos de Alta Resistência (CAR), mas um enfoque mais amplo têm sido dado às outras propriedades desses concretos, tais como: módulo de elasticidade, alta densidade, baixa permeabilidade e resistência a

agentes agressivos. Portanto, torna-se lógico denominar este concreto com um termo mais abrangente, como Concreto de Alto Desempenho (CAD). NAAMAN et al.(1993) complementa esta definição dizendo que estes concretos podem ainda conter materiais tais como cinza volante, pozolanas, sílica ativa, fibras, aditivos químicos e outros materiais, individualmente ou em várias combinações.

Para misturas feitas com agregados usuais, os concretos de alta resistência são aqueles que tem resistência característica à compressão maior que $40 \mathrm{MPa}$, segundo MEHTA \& MONTEIRO(1994), GONZALEZ-ISABEL(1993) e PEREIRA NETO \& DJANIKIAN(1995). Dois argumentos foram usados para justificar essa definição, segundo SHAH(1981) apud MEHTA \& MONTEIRO(1994) ${ }^{1}$ :

1 - A maioria dos concretos convencionais estão na faixa de $21 \mathrm{MPa}$ a $42 \mathrm{MPa}$. Para produzir concretos com mais de $42 \mathrm{MPa}$, são necessários controle de qualidade severo e mais cuidado na seleção e na dosagem dos materiais (plastificantes, aditivos minerais, tipo e dimensão dos agregados etc.).

2 - Estudos experimentais mostraram que, em muitos aspectos, a microestrutura e as propriedades do concreto com resistência à compressão acima de $42 \mathrm{MPa}$, são consideravelmente diferentes das do concreto convencional.

A ASSOCIAÇÃO BRASILEIRA DE NORMAS TÉCNICAS(1992), na NBR 8953, classifica os concretos em duas classes, I e II, onde os concretos da Classe I são aqueles cujas resistências características à compressão variam de $10 \mathrm{MPa}$ a $50 \mathrm{MPa}$, e os concretos da Classe II são aqueles cujas resistências características à compressão são: $55 \mathrm{MPa}, 60 \mathrm{MPa}, 70 \mathrm{MPa}$ e $80 \mathrm{MPa}$. Portanto pode-se considerar os concretos da Classe II como concretos de alta resistência.

\footnotetext{
${ }^{1}$ SHAH, S.P.(1981). Concr. Int., Vol.3, No 5, pp. 94-98 apud MEHTA \& MONTEIRO(1994). Concreto: Estruturas, Propriedades e Materiais. PINI, São Paulo
} 
O conceito de alta resistência tem variado ao longo dos anos, o que pode ser confirmado no Boletim 197 do CEB-FIP(1990) que recomenda como limite superior de resistência característica à compressão, $80 \mathrm{MPa}$. Após o advento da sílica ativa o cimento deixou de ser fator limitante para a obtenção de maiores resistências, que passam a depender mais das propriedades dos agregados, que variam de região para região em função do grande número de rochas existentes.

A diferença entre o Concreto de Resistência Normal (CRN) e o CAD está também no conhecimento de como fazer concreto. Os componentes são os mesmos: cimento, água e agregados, sendo que no CAD é necessário além desses componentes, a implementação de aditivos redutores de água de alto efeito, como por exemplo, os superplastificantes. A presença de outros materiais como: escórias de alto forno, cinzas volantes e sílica ativa, não é obrigatória para que o concreto seja de alta resistência. $\mathrm{O}$ conhecimento mais importante para produção do $\mathrm{CAD}$, envolve uma relação água/cimento extremamente baixa, aliada a trabalhabilidade adequada para compactação. Sem o uso de um superplastificante, a redução da quantidade de água em um determinado concreto fresco resultaria em mistura não trabalhável. Simultaneamente, a quantidade de cimento não pode ser aumentada excessivamente, não somente pelo custo, mas porque acarretaria problemas térmicos.

O concreto de alto desempenho além de ser empregado para se conseguir maiores resistências e reduzir as dimensões dos elementos, também é usado para melhorar a durabilidade do material.

A alta resistência do CAD é especialmente vantajosa, como definido por CLAESON et al.(1996), em elementos comprimidos, tais como pilares, que podem ser feitos mais esbeltos no projeto e, consequentemente, trazendo benefícios econômicos. Um aumento na resistência à compressão permite menores seções transversais que por sua vez, necessitam menos concreto e assim mais espaço utilizável no pavimento.

Muitas investigações têm sido feitas relacionando a distribuição do tamanho dos poros do concreto e a sua resistência, mostrando que a redução da porosidade ou do tamanho máximo dos poros leva à um aumento da resistência à compressão (Boletim 197 do CEB-FIP(1990)). Esta redução influencia a “zona de transição”, que 
é a região de ligação da pasta com o agregado graúdo (fig. 2.1). A resistência desta zona tem influência direta na resistência do concreto. Segundo MEHTA \& MONTEIRO(1994), além do grande volume de vazios capilares e de cristais orientados de hidróxido de cálcio, um importante fator responsável pela baixa resistência da zona de transição no concreto é a presença de microfissuras.

Para diminuir a porosidade do concreto e, consequentemente, aumentar a resistência, faz-se necessário o uso de fatores a/c mais baixos, o que reduz a trabalhabilidade do material, dificultando assim o manuseio. Portanto, algumas vezes são usados aditivos superplastificantes para se conseguir resistências mais altas sem a perda da trabalhabilidade.

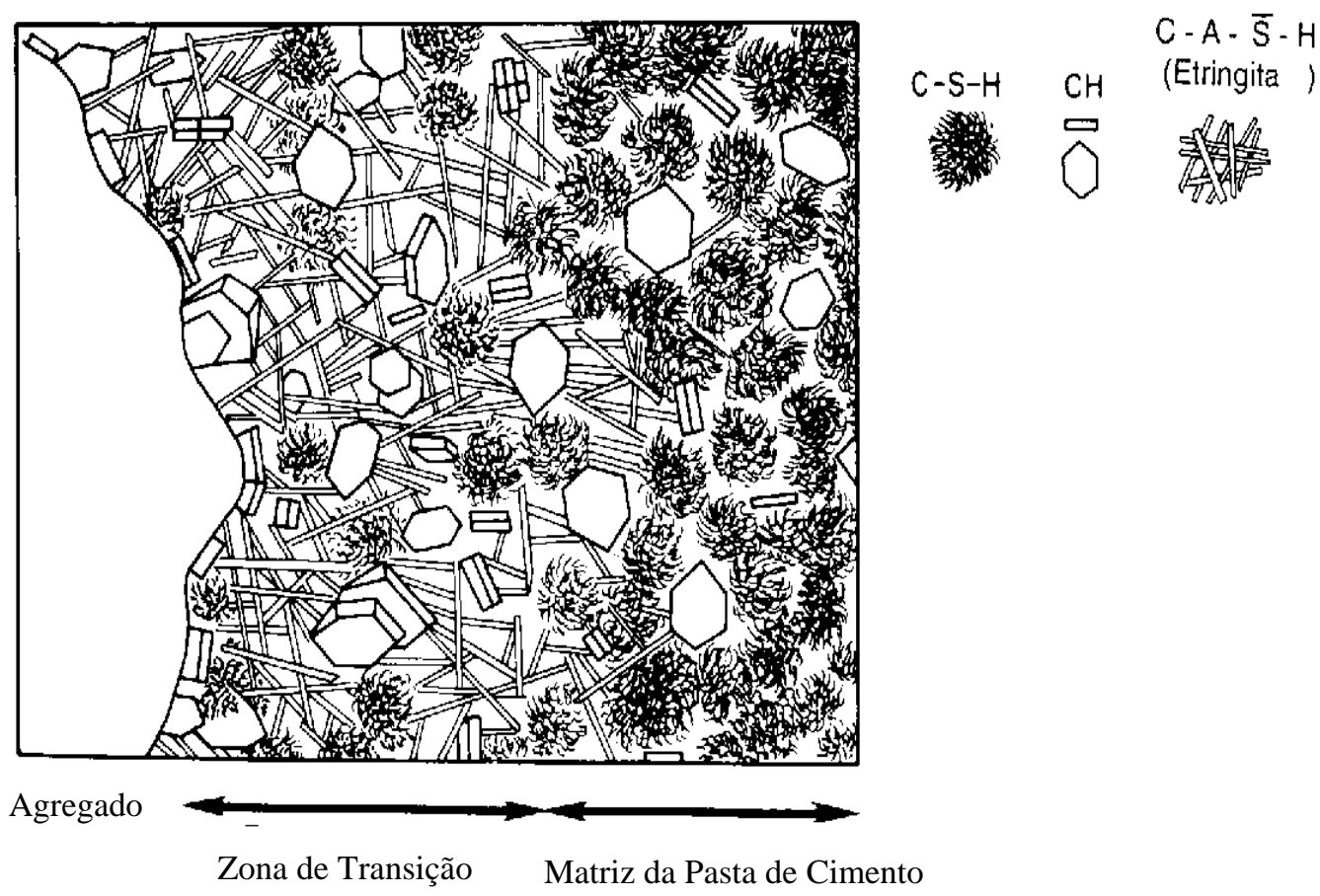

FIGURA 2.1 - Representação da Zona de Transição e da Matriz da Pasta de Cimento no Concreto (MEHTA \& MONTEIRO(1994))

O CAD é um material de construção cuja utilização têm aumentado nestes anos pelos seguintes motivos: redução de custos, construção de pilares mais esbeltos, maior rigidez dos elementos, encurtamento axial menor, menor efeito de retração, durabilidade, impermeabilidade e tempo de desmoldagem menor. Uma certa importância deve ser dada ao fato que parâmetros para projeto e fatores de segurança 
usados quando se adotam concretos da Classe I, não devem ser extrapolados para concretos destas resistências. Cuidados adicionais devem ser tomados, principalmente por causa da redução da ductilidade do CAD.

As principais diferenças, segundo o Boletim 197 do CEB-FIP(1990), entre as curvas tensão x deformação para o concreto convencional e o CAD são (figura 2.2):

- relação tensão x deformação mais linear até uma porcentagem alta da resistência última;

- maior deformação para a resistência última;

- forma mais inclinada da parte descendente da curva.

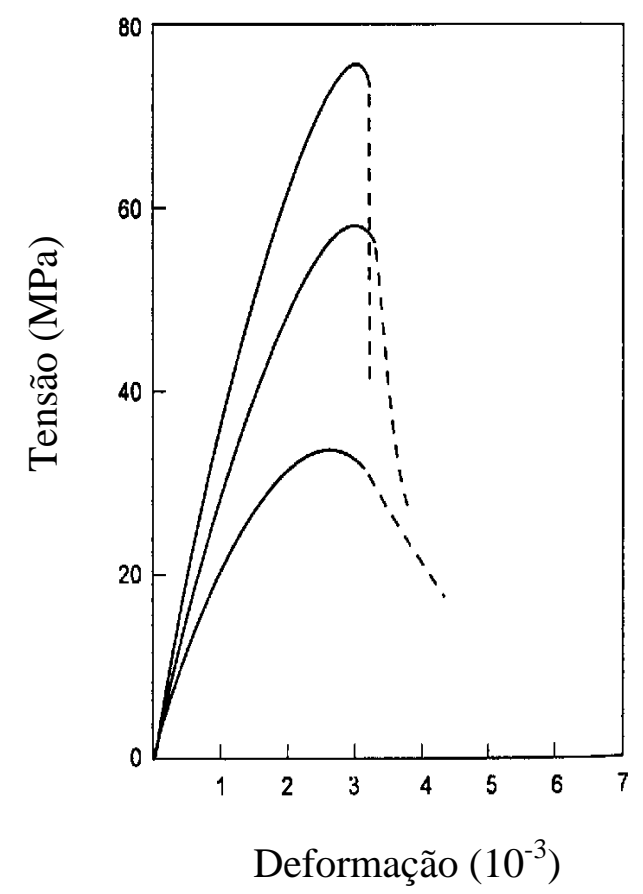

FIGURA 2.2 - Curvas Tensão x Deformação Típicas de Concretos de Alto Desempenho (NEVILLE(1997))

Estas mudanças na resposta à solicitação do material são conseqüências do aumento da aderência pasta-agregado graúdo no CAD. A relação tensão $x$ deformação mais linear reflete a redução da micro-fissuração para níveis baixos de tensões e a forma mais inclinada da parte descendente da curva indica a redução da ductilidade do material. 


\subsection{2- MATERIAIS CONSTITUINTES}

\subsubsection{1- Material Cimentante}

\section{Cimento}

O cimento utilizado para uma mistura de concreto de alta resistência não tem necessariamente que ser um cimento especial. Pode ser usado cimento comum, desde que o material atenda às condições de uso do concreto convencional.

Na opinião de HOWARD \& LEATHAM(1989) apud DAL MOLIN(1995)², não existem critérios científicos que especifiquem o cimento mais adequado para a produção de concretos de alta resistência. O melhor cimento é, de acordo com o AMERICAN CONCRETE INSTITUTE(1992) ACI 363R-92, aquele que apresenta menor variabilidade em termos de resistência à compressão.

NEVILLE(1997) diz que do ponto de vista reológico, pode-se postular um cimento ideal para o concreto de alto desempenho: não muito fino (provavelmente com finura Blane até $400 \mathrm{~m}^{2} / \mathrm{kg}$ ) e teor muito baixo de $\mathrm{C}_{3} \mathrm{~A}$, cuja atividade é facilmente controlada pelos íons sulfato provenientes da dissolução dos sulfatos do cimento.

GONZALES-ISABEL(1993) diz que existe uma relação direta entre as características resistentes do cimento utilizado e aquelas do concreto resultante. Os resultados de distintas investigações a respeito demonstram que, apesar da resistência, existem outros fatores não menos importantes que condicionam a relação buscada, como por exemplo, a finura do grão do cimento ou a sua composição mineralógica.

Pelo fato de ser um componente de grande importância na composição do concreto, indicam-se ensaios para obtenção da resistência do cimento antes do seu uso na composição dos concretos de alto desempenho.

\section{Sílica Ativa}

A sílica ativa é um subproduto resultante do processo de obtenção do ferrosilício e silício-metálico, utilizados na fabricação de componentes eletrônicos, silicone e alumínio.

\footnotetext{
${ }^{2}$ HOWARD \& LEATHAM(1989). Concr. Int. v.11, n.4 April, p.26-30 apud DAL MOLIN(1995). Tese de Doutorado. USP - São Paulo.
} 
Este material pode ser comercializado da seguinte forma, segundo DAL MOLIN(1995): no estado natural, sem nenhum tratamento após a captação e filtragem; densificada, através da compactação (normalmente com ar comprimido) das partículas de sílica ativa após a filtragem; sob forma de lama, onde a sílica ativa é pré-misturada com água; pré-misturada com cimento, normalmente contendo 6,5\% a $8 \%$ de sílica ativa sob a massa de cimento; micropelotizada, similar à densificada porém é adicionada uma pequena quantidade de água para produzir aglomerações maiores (massa específica aparente de aproximadamente $700 \mathrm{~kg} / \mathrm{m}^{3}$ ); ou ainda em qualquer uma das formas anteriores incorporando aditivos químicos à sílica (plastificantes, superplastificantes, retardadores, incorporadores de ar e/ou outros).

Ao contrário do que se pensa, a sílica ativa não é componente essencial do CAD. Não há vantagem em dispensar seu uso, desde que seja disponível e econômica, pois sua utilização simplifica a produção de CAD e torna viável a obtenção de resistências à compressão de $60 \mathrm{MPa}$ a $90 \mathrm{MPa}$. No entanto para resistências maiores, o uso da sílica é essencial, o que afeta o custo do concreto.

\section{Pozolanas}

As pozolanas, tais como as cinzas volantes ou escórias de alto forno, normalmente adicionadas ao concreto convencional, também podem ser usadas como adições ao concreto de alta resistência, ou ainda a cinza de casca de arroz, que segundo DAL MOLIN(1995), tem se mostrado mais efetiva, além da sílica ativa, no aumento da resistência do concreto, pois mais do que o efeito químico, atuam também fisicamente densificando a matriz e a zona de transição.

\subsubsection{2 - Agregados}

A qualificação dos agregados para o emprego em concretos de alto desempenho baseia-se no atendimento das exigências mínimas prescritas nas normas atuais para concretos convencionais (NBR 7211(1983); NBR 12654(1992)). 


\section{Agregado Graúdo}

\section{a) Dimensão Máxima Característica}

Existem na literatura opiniões diferenciadas quanto à adequada dimensão máxima para concretos de alta resistência.

De acordo com GJORV(1992) apud DAL MOLIN(1995)³, a dimensão máxima do agregado graúdo para uso em concretos de alta resistência deve ficar entre $10 \mathrm{~mm}$ e $14 \mathrm{~mm}$.

Já MEHTA \& MONTEIRO(1994) e o ACI 363R-92, apontam o uso de agregados com limite máximo de $19 \mathrm{~mm}$ como sendo mais adequado, ou até mesmo $25 \mathrm{~mm}$.

GONZALES-ISABEL(1993) recomenda a adoção de agregados com dimensão máxima compreendida entre $10 \mathrm{~mm}$ e $12,5 \mathrm{~mm}$, mas não se deve descartar o uso de agregados cuja dimensão máxima característica está compreendida entre $20 \mathrm{~mm}$ e $25 \mathrm{~mm}$, se a rocha de origem for suficientemente forte e homogênea.

Segundo DAL MOLIN(1995), existem várias razões pelas quais um agregado de menor dimensão máxima é capaz de produzir um concreto mais resistente. Uma delas é que como o agregado é normalmente britado, durante as operações de desmonte das rochas com explosivos e britagem dos blocos podem ocorrer danos à microestrutura dos agregados, sendo probabilisticamente, mais provável remanescerem falhas e fissuras em agregados de maiores dimensões, e uma outra explicação é que quanto menor o agregado, menor a superfície capaz de reter água durante a exsudação do concreto fresco, o que propicia uma zona de transição de menor espessura e, consequentemente, mais resistente.

\section{b) Resistência à Compressão}

Nos concretos de alta resistência, a capacidade do agregado freqüentemente limita as propriedades mecânicas do concreto. Para os agregados convencionais, o limite superior, para resistência à compressão, situa-se em torno de $120 \mathrm{MPa}$ a 140MPa, conforme cita o Boletim 197 do CEB-FIP(1990).

\footnotetext{
${ }^{3}$ GJORV, O.E.(1992). High strength concrete. In: ADVANCES IN CONCRETE TECHNOLOGY, Athens PROCEEDINGS, p.21-77 apud DAL MOLIN, D.C.C(1995). Tese de Doutorado. USP - São Paulo.
} 


\section{c) Forma e Textura Superficial}

$\mathrm{Na}$ composição do concreto, a aderência pasta de cimento - agregado exerce um importante papel para a interação entre os dois componentes. Assim, a forma e a textura superficial do agregado são fatores relevantes no comportamento mecânico e, segundo NEVILLE(1997), a resistência à flexão é mais influenciada do que a resistência à compressão.

Ainda não é completamente conhecido o papel da forma e da textura do agregado na evolução da resistência do concreto, mas possivelmente uma textura mais áspera resultaria em maiores forças de aderência entre as partículas e a matriz de cimento.

Segundo o ACI 363R-92, embora os agregados angulares possam produzir resistências mecânicas maiores, efeitos opostos no aumento do consumo de água e redução da trabalhabilidade podem surgir se a angulosidade for muito acentuada.

A forma e a textura da superfície do agregado são características cuja incidência é decisiva sobre uma propriedade primordial do concreto, que é a compacidade, segundo GONZALES-ISABEL(1993).

A máxima compacidade só vem associada a seixos rolados de forma sensivelmente esféricas ou à pedras britadas de forma próxima à cúbica. Uma certa rugosidade superficial dos agregados graúdos melhora a aderência necessária à pasta de cimento.

\section{Agregado Miúdo}

O agregado cujo diâmetro não ultrapassa $4,8 \mathrm{~mm}$ é considerado como agregado miúdo conforme a NBR 7217(1987): são as areias naturais ou artificiais. Agregados miúdos com partículas arredondadas e lisas necessitam menos água de mistura e, portanto, são preferíveis para a produção de concretos de alta resistência, conforme indica o ACI 363R-92.

Como a quantidade de finos em concreto de alta resistência é normalmente alta, DAL MOLIN(1995) aconselha usar menor quantidade de areia mas com módulo de finura maior. 


\subsubsection{3 - Água}

A água utilizada para a produção de concretos de alto desempenho, pedem os mesmos requisitos que a água usada para a fabricação dos concretos convencionais.

A quantidade usada para execução de misturas de concreto de alta resistência é a mínima possível, resultando em baixas relações água/cimento.

\subsubsection{4 - Aditivos Químicos}

A obtenção do concreto de alta resistência está altamente ligada ao uso de aditivos redutores de água no concreto. A alta resistência é conseguida utilizando-se uma baixa relação água/cimento, o que influi de maneira negativa na trabalhabilidade do concreto, sendo necessário o uso destes materiais, para que possa ser feita a moldagem dos elementos.

Um aditivo pode ser definido, segundo NEVILLE(1997), como sendo um produto químico que, exceto em casos especiais, é adicionado à mistura de concreto em teores não maiores que $5 \%$ em relação à massa de cimento durante a mistura ou em uma mistura complementar antes do lançamento do concreto.

Os aditivos podem ser orgânicos ou inorgânicos quanto à composição, mas a natureza química é a principal característica, ao contrário dos minerais. Os produtos minerais incorporados à mistura em teores maiores do que 5\% quase que invariavelmente são designados como materiais cimentícios ou adições.

Os aditivos são classificados pela função no concreto, mas muitas vezes apresentam mais de uma função. A ASTM C 494(1992) classifica os aditivos em plastificantes, retardadores, aceleradores, plastificantes retardadores, plastificantes aceleradores, superplastificantes e superplastificantes retardadores.

Nas ocasiões em que se utilizam elevadas doses de superplastifcantes em concretos de baixa relação a/c, se observam efeitos reológicos muito diferentes. Assim a variação da marca do cimento empregado, segundo GONZALESISABEL(1993) pode implicar em variações importantes na trabalhabilidade do concreto ou no tempo de pega do mesmo. 


\subsection{3 - PROPRIEDADES MECÂNICAS DO CAD}

O concreto de alto desempenho apresenta melhorias no seu comportamento mecânico, em relação ao concreto convencional, tanto no estado fresco como no estado endurecido. Neste item são apresentados comentários gerais e indicações de normas sobre algumas propriedades mecânicas do concreto de alto desempenho no estado endurecido, tais como a resistência à compressão, resistência à tração, módulo de elasticidade e coeficiente de Poisson.

\subsubsection{1 - Resistência à Compressão}

Normalmente a dosagem do concreto é feita de uma maneira que a resistência média à compressão obtida em ensaios exceda a resistência característica à compressão especificada em projeto em um valor suficientemente alto para minimizar a freqüência relativa dos resultados dos ensaios que ficarem abaixo dos valores especificados (ACI 363R-92). A diferença limite entre o valor de cada teste individual e da média obtida com todos os valores, é quantificada através do cálculo do desvio padrão. O Boletim 197 do CEB-FIP(1990) estabelece que a relação entre essas resistências pode expressar-se segundo a fórmula 2.1.

$\frac{f_{c_{\text {obra }}}}{f_{\text {claboratório }}}=1-\frac{f_{c k}(M P a)}{250}$

Entende-se que o $\mathrm{f}_{\mathrm{c}, \mathrm{obra}}$ é a resistência medida em testemunhos extraídos da

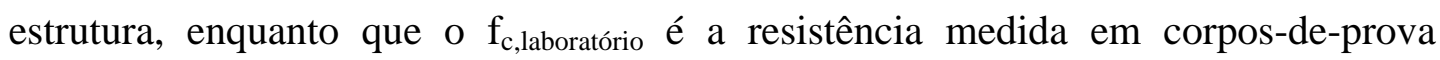
moldados durante a concretagem.

Esta fórmula quando aplicada à concretos de resistência igual ou superior à $80 \mathrm{MPa}$ conduz a adoção de valores não superiores à 0,68 . Menos conservativa é a ISO(1987) apud Boletim 197 do $\operatorname{CEB}-\mathrm{FIP}(1990)^{4}$ que propõe para esta relação coeficientes compreendidos entre 0,75 e 0,90 .

\footnotetext{
${ }^{4}$ INTERNATIONAL ORGANIZATION FOR STANDARDZATION(1987). Methods for assessment of the compressive strength of concrete in structures, apud CEB-FIP(1990). High strength concrete state of the art report. CEB Bulletin d'Information, n.197.
} 
Todos os fatores que podem afetar a variabilidade das resistências e a sua medida, devem ser considerados quando da seleção dos materiais que constituem a mistura e do cálculo do desvio padrão aceitável para os resultados das resistências. O concreto de alto desempenho tem um ganho de resistência com o tempo maior que o concreto convencional nas primeiras idades, mas este ganho em porcentagem é igual ou menor que o ocorrido no concreto convencional.

Outras propriedades do concreto, tais como: relação tensão x deformação; resistência à tração, módulo de elasticidade, são expressas em função da resistência à compressão do concreto. Geralmente as expressões são baseadas em dados experimentais para resistências à compressão menores que $41 \mathrm{MPa}$.

Embora a confiança no concreto de alto desempenho tenha aumentado, sentese ainda que o comportamento frágil do material requer atitudes conservativas para evitar o colapso, brusco ou frágil, em função das altas tensões localizadas. Deste modo, uma redução na resistência tem sido recomendada, implicando num aumento de $10 \%$ do fator $\gamma_{\mathrm{m}}$ para os concretos C100. Uma possível redução da resistência devido à altas temperaturas (causadas pelos efeitos do processo de hidratação ou por altos gradientes de temperatura causando fissuração) não está incluído no aumento do fator $\gamma_{\mathrm{m}}$. A proposta do Boletim 228 do CEB-FIP(1995) é que o fator $\gamma_{\mathrm{c}}$ deve ser aumentado pelo fator:

$$
\gamma_{h s c}=\frac{1}{\left(1,1-\frac{f_{c k}}{500}\right)} \quad \text { para } 50 \mathrm{MPa}<\mathrm{f}_{\mathrm{ck}}<100 \mathrm{MPa}
$$

Para o concreto de alta resistência a resistência à compressão deve ser obtida em corpos-de-prova cilíndricos, sendo que a referência citada não indica as dimensões do cilindro. Ela cita ainda que outros tipos de corpos-de-prova (tais como cubos de $100 \mathrm{~mm}$ de aresta, cilindros de $100 \mathrm{~mm}$ x 200mm) podem ser usados para controle de produção desde que fatores de conversão sejam conhecidos para o concreto em questão. 


\subsubsection{2 - Resistência à Tração}

Dewar(1964), conforme cita o Boletim 197 do CEB-FIP(1990), estudou a relação entre a resistência à tração indireta e a resistência à compressão de concretos com resistência à compressão até aproximadamente 84MPa aos 28 dias. Ele concluiu que para baixas resistências, a resistência à tração indireta é da ordem de $10 \%$ da resistência à compressão, mas para resistências à compressão maiores, esta porcentagem deve ser reduzida para $5 \%$.

CARRASQUILLO et al.(1981) indicam a expressão 2.3 para o cálculo da resistência à tração em função da resistência à compressão do concreto.

$$
f_{s p}^{\prime}=0,54 \sqrt{f_{c}^{\prime}}(M P a) \quad \text { para } 21 \mathrm{MPa}<\mathrm{f}_{\mathrm{c}}{ }^{\prime}<83 \mathrm{MPa}
$$

$\mathrm{Na}$ falta de dados mais apurados para um concreto particular os limites superiores e inferiores da resistência característica à tração $f_{c t k, m a x}$ e $f_{c t k, m i n}$ devem ser estimados usando a resistência característica à compressão, com as equações 2.4, 2.5 e 2.6, indicadas pelo Boletim 228 do CEB-FIP(1995), que são estritamente válidas para concretos com resistências à compressão até 50MPa.

$$
\begin{aligned}
& f_{c t k, \text { min }}=f_{c t k 0, \min }\left(\frac{f_{c k}}{f_{c k 0}}\right)^{\frac{2}{3}} \\
& f_{c t k, \text { máx }}=f_{c t k 0, \text { máx }}\left(\frac{f_{c k}}{f_{c k 0}}\right)^{\frac{2}{3}}
\end{aligned}
$$

onde:

$$
\begin{aligned}
& \mathrm{f}_{\text {ck0 }}=10 \mathrm{MPa} \\
& \mathrm{f}_{\text {ctk } 0 \text {,min }}=0,95 \mathrm{MPa} \\
& \mathrm{f}_{\text {ctk0,máx }}=1,85 \mathrm{MPa}
\end{aligned}
$$

Para algumas verificações de projeto ou para estimativas de outras propriedades do concreto é necessário se referir à um valor médio da resistência à tração $\mathrm{f}_{\mathrm{ctm}}$ associada à resistência característica à compressão. Neste caso $\mathrm{f}_{\mathrm{ctm}}$ deve ser estimado pela equação 2.6. 
$f_{c t m}=f_{c t k 0, m}\left(\frac{f_{c k}}{f_{c k 0}}\right)^{\frac{2}{3}}$

onde:

$\mathrm{f}_{\mathrm{ctk} 0, \mathrm{~m}}=1,40$

Para concretos com resistências acima deste limite de $50 \mathrm{MPa}$, as equações superestimam a resistência à tração do concreto e devem ser substituídas pelas equações $2.4 \mathrm{~b}, 2.5 \mathrm{~b}$ e $2.6 \mathrm{~b}$. As equações também podem ser usadas para concretos de resistências normais.

$f_{c t k, \text { min }}=f_{c t k 0, \min }\left(\frac{f_{c k}+\Delta f}{f_{c k 0}+\Delta f}\right)^{0,6}$
$f_{c t k, \text { máx }}=f_{c t k 0, \text { máx }}\left(\frac{f_{c k}+\Delta f}{f_{c k 0}+\Delta f}\right)^{0,6}$

onde:

$\mathrm{f}_{\mathrm{ck} 0}=10 \mathrm{MPa}$

$\Delta \mathrm{f} \quad=8 \mathrm{MPa}$

$\mathrm{f}_{\mathrm{ctk} 0 \text {, mín }}=1,22 \mathrm{MPa}$

$\mathrm{f}_{\text {ctk } 0 \text {,máx }}=2,38 \mathrm{MPa}$

Respectivamente para uma estimativa do valor médio da resistência à tração, usa-se a equação $2.6 \mathrm{~b}$ :

$f_{c t m}=f_{c t k 0, m}\left(\frac{f_{c k}+\Delta f}{f_{c k 0}+\Delta f}\right)^{0,6}$

onde:

$\mathrm{f}_{\mathrm{ctk} 0, \mathrm{~m}}=1,80 \mathrm{MPa}$

A resistência à tração indireta $\mathrm{f}_{\mathrm{ct}, \mathrm{sp}}$ e a resistência à tração na flexão $\mathrm{f}_{\mathrm{ct}, \mathrm{f}}$ devem ser obtidas de ensaios realizados segundo a NBR 7222(1982) e a NBR 12142(1991), respectivamente, conforme indica o Texto para Revisão da NB1(1997), para concretos de resistência característica à compressão até 50MPa. A resistência à tração 
direta $\mathrm{f}_{\mathrm{ct}}$ pode ser considerada igual à $0,9 \mathrm{f}_{\mathrm{ct}, \mathrm{sp}}$ ou $0,7 \mathrm{f}_{\mathrm{ct}, \mathrm{f}}$ ou, na falta de ensaios para obtenção de $f_{c t, s p}$ e $f_{c t, f}$, pode ser avaliada por meio das equações 2.7, 2.8 e 2.9.

$$
\begin{aligned}
& f_{c t m}=0,3 f_{c k}^{\frac{2}{3}} \mathrm{com}_{\mathrm{ctm}} \text { e } \mathrm{f}_{\mathrm{ck}} \text { em MPa } \\
& f_{c t k, \mathrm{inf}}=0,7 f_{c t m} \\
& f_{c t k, \text { sup }}=1,3 f_{c t m}
\end{aligned}
$$

\subsubsection{3 - Módulo de Elasticidade}

Segundo o ACI 363R-92, Thoman e Raeder(1934) encontraram valores para o módulo de elasticidade determinado como a reta tangente à curva tensão $\mathrm{x}$ deformação, do concreto sob compressão uniaxial, a 25\% da máxima tensão obtida (de $29 \mathrm{GPa}$ a 36GPa) para concretos com resistência média à compressão de 69MPa a 76MPa, e outros pesquisadores, tais como Kaar et al.(1978), Smith(1964) e Ahmad(1981), também mencionados no ACI 363R-92, encontraram valores para o módulo de elasticidade do concreto de alto desempenho da ordem de $31 \mathrm{GPa}$ a 45GPa, dependendo do método de determinação do módulo.

Uma correlação entre o módulo de elasticidade $E_{c}$ e a resistência à compressão $\mathrm{f}_{\mathrm{c}}$ ' para concretos convencionais está relatado em CARRASQUILLO et al.(1981) como indica a expressão 2.10:

$$
E_{c}=3320 \sqrt{f_{c}^{\prime}}+6900 \quad(\mathrm{em} \mathrm{MPa}) \quad \text { para } 21 \mathrm{MPa}<\mathrm{f}_{\mathrm{c}}{ }^{\prime}<83 \mathrm{MPa}
$$

Os valores do módulo de elasticidade para o concreto convencional podem ser estimados com a resistência à compressão característica usando a equação 2.11, segundo o Boletim 228 do CEB-FIP(1995).

$$
E_{c i}=E_{c 0}\left[\frac{\left(f_{c k}+\Delta f\right)}{f_{c m 0}}\right]^{\frac{1}{3}}
$$

onde:

$\mathrm{E}_{\mathrm{ci}} \quad=$ é o módulo de elasticidade do concreto na idade de 28 dias (MPa);

$\mathrm{f}_{\mathrm{ck}}=$ é a resistência característica à compressão do concreto; 


$$
\begin{aligned}
\Delta \mathrm{f} & =8 \mathrm{MPa} \\
\mathrm{f}_{\mathrm{cm} 0} & =10 \mathrm{MPa} \\
\mathrm{E}_{\mathrm{c} 0} & =2,15 \times 10^{4} \mathrm{MPa} .
\end{aligned}
$$

Quando a resistência média à compressão do concreto aos 28 dias é conhecida, $\mathrm{E}_{\mathrm{ci}}$ deve ser estimado através da equação 2.12 .

$$
E_{c i}=E_{c 0}\left[\frac{f_{c m}}{f_{c m 0}}\right]^{\frac{1}{3}}
$$

Quando somente uma análise elástica da estrutura de concreto é feita, uma redução do módulo de elasticidade $\mathrm{E}_{\mathrm{c}}$, de acordo com a equação 2.13 , deve ser usada, para levar em conta a deformação plástica inicial.

$E_{c}=0,85 E_{c i}$

A fórmula indicada pela norma norueguesa NS 3473E(1992) é a 2.14.

$E_{c n}=10000 f_{c n}^{0,3} \quad(\mathrm{MPa})$

O módulo de elasticidade secante, a ser empregado em projeto, deve ser obtido segundo ensaio descrito na NBR 8522(1983), conforme indica o Texto para Revisão da NB1/78(1997) para concretos com resistência característica à compressão até $50 \mathrm{MPa}$, considerando um nível de tensão igual à $40 \%$ da resistência característica estimada. Quando não forem feitos ensaios e não existirem dados mais precisos sobre o concreto usado, na idade de 28 dias, pode-se estimar o valor do módulo de elasticidade secante médio usando a equação 2.15 .

$$
E_{c m, s}=4700 f_{c k}^{\frac{1}{2}} \quad \mathrm{com} \mathrm{E}_{\mathrm{cm}, \mathrm{s}} \text { e } \mathrm{f}_{\mathrm{ck}} \text { em MPa }
$$

\subsubsection{4 - Coeficiente de Poisson}

Dados experimentais para o coeficiente de Poisson para o concreto de alto desempenho são muito escassos. Segundo o ACI 363R-92, Perenchio e Klieger(1978) encontraram valores para o coeficiente de Poisson para o concreto de alto desempenho com resistências variando de 55MPa a $80 \mathrm{MPa}$, entre 0,20 e 0,28. 
Eles concluíram que o coeficiente de Poisson tende a diminuir com o aumento da relação água/cimento.

Na fase elástica de deformação, segundo GONZALES-ISABEL(1993), o coeficiente de Poisson dos CAR é comparável com os geralmente adotados para os concretos de resistências à compressão menores e, dependendo do nível de solicitação, compreendidos entre 0,18 e 0,24 .

Para tensões de compressão menores que $0,5 f_{c}$ e tensões de tração menores que $\mathrm{f}_{\mathrm{ct}}, \mathrm{o}$ coeficiente de Poisson $v$ pode ser tomado igual à 0,20 .

Baseado nessas informações, o coeficiente de Poisson do concreto de alto desempenho para o limite elástico parece comparável ao limite esperado dos valores do concreto convencional.

Nos ensaios realizados para esta pesquisa, os valores encontrados para o coeficiente de Poisson para os concretos com adição de fibras, com a taxa volumétrica variando entre $0,25 \%$ e $1,00 \%$, ficaram entre 0,11 e 0,21 , para resistência média do concreto de aproximadamente $80 \mathrm{MPa}$.

\subsubsection{5 - Relação Tensão x Deformação}

VASCONCELOS(1998), com a colaboração do Eng. José Zamarion Ferreira Diniz, descreve o comportamento do CAD com relação aos diagramas Tensão $\mathrm{x}$ Deformação. $\mathrm{O}$ texto escrito para orientar uma palestra ministrada pelo autor, tinha a finalidade de sugerir critérios para a Revisão da NB1/78.

Os diagramas Tensão x Deformação do concreto são sempre assumidos como sendo do tipo parábola-retângulo. Isto é inteiramente arbitrário, sendo mais uma questão de costume do que de necessidade. Quanto maior a resistência do concreto, tanto menor é o trecho retangular, a parábola se aproximando mais de uma reta. A deformação última do concreto $\varepsilon_{\mathrm{cu}}$ diminui de $3,5 \%$ até $2,4 \%$, de C50 a C80. Até C50 pode-se adotar o valor 3,5\% .

Ensaios feitos com controle das deformações mostram o andamento da curva Tensão x Deformação mesmo depois de atingido o valor máximo da tensão. Este ramo descendente do diagrama é muito difícil de ser obtido com precisão, é muito instável e descreve o concreto já todo microfissurado internamente. 
O engenheiro José Zamarion Ferreira Diniz preparou os diagramas representados na figura 2.3, apud VASCONCELOS(1998), nos quais foi fixado, para todas as classes em $2 \%$ o valor da deformação correspondente à máxima tensão de cálculo do concreto $(0,85)$.

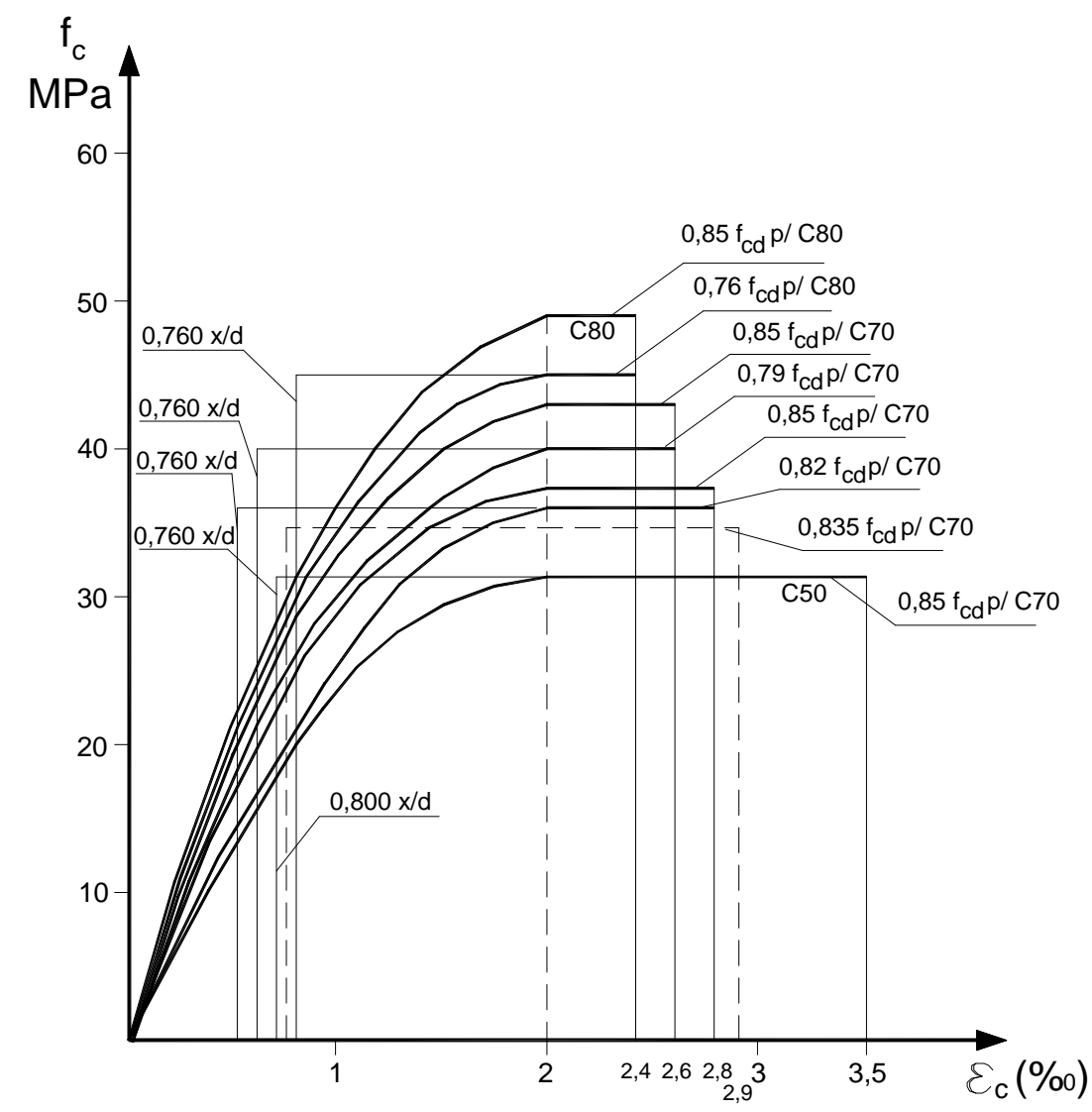

FIGURA 2.3 - Diagramas Tensão x Deformação de Cálculo Propostos por Zamarion (VASCONCELOS(1998))

Para efeito de cálculo, o diagrama parábola-retângulo pode ser transformado num retângulo equivalente onde a tensão máxima varia de $0,85 \mathrm{f}_{\mathrm{cd}}$ até $0,76 \mathrm{f}_{\mathrm{cd}}$, sendo o primeiro valor aplicado até C50.

A altura do retângulo equivalente é colocada como uma fração $\beta$ da profundidade $\mathbf{x}$ da Linha Neutra (L.N.):

$$
\begin{aligned}
& \beta=0,80 \text { para concretos até C50; } \\
& \beta=0,76 \text { para concretos de C80. }
\end{aligned}
$$


A tensão máxima de cálculo é considerada como uma fração $\alpha$ da resistência $\mathrm{f}_{\mathrm{cd}}$. Para concretos das classes até C50, este valor continua sendo igual a 0,85. À medida que a classe de concreto vai aumentando, o valor de $\alpha$ vai diminuindo. A figura 2.4 expõe sob forma gráfica a definição de $\alpha$ e $\beta$.

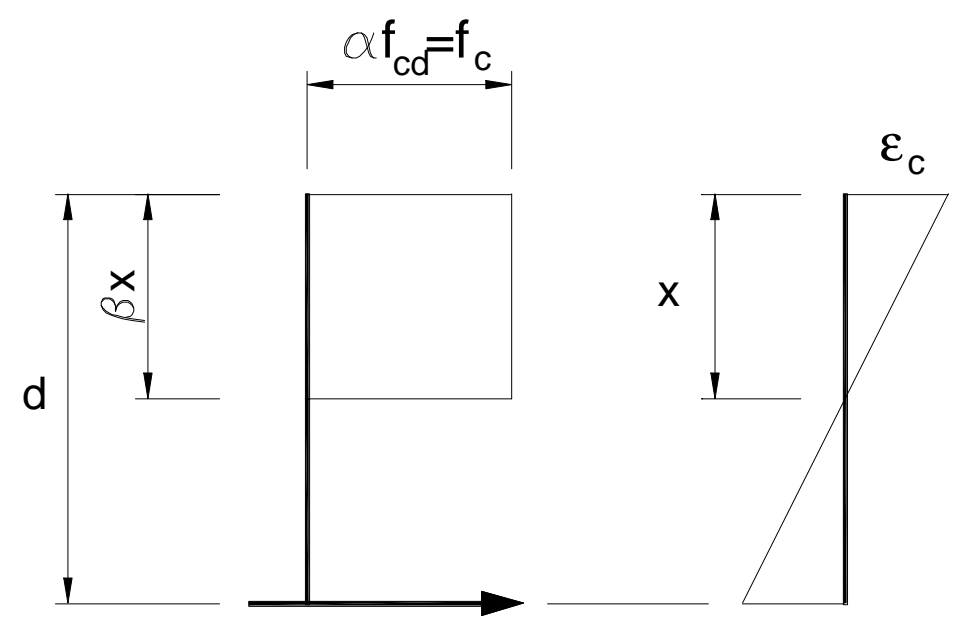

FIGURA 2.4 - Definição de $\alpha$ e $\beta$ (VASCONCELOS(1998))

A formulação proposta por VASCONCELOS(1998) determina os parâmetros $\alpha$ e $\beta$, equações 2.16 e 2.17 , com a condição de que tanto a área total parábolaretângulo como a posição do seu baricentro coincidam com os valores correspondentes do retângulo equivalente.

$$
\begin{gathered}
\alpha=\frac{\left(3 \varepsilon_{c}-2\right)^{2} 0,85}{\left(3 \varepsilon_{c}^{2}-4 \varepsilon_{c}+2\right) 3} \\
\beta=\frac{3 \varepsilon_{c}^{2}-4 \varepsilon_{c}+2}{\left(3 \varepsilon_{c}-2\right) \varepsilon_{c}}
\end{gathered}
$$

A tabela 2.1 mostra os valores propostos por José Zamarion Ferreira Diniz, citados em VASCONCELOS(1998), e aqueles calculados por este autor com as fórmulas 2.16 e 2.17. Percebe-se que as diferenças são insignificantes. 
Tabela 2.1 - Valores dos Coeficientes proposto por Diniz (VASCONCELOS(1998))

\begin{tabular}{|c|c|c|c|c|c|c|c|}
\hline Classe & $\begin{array}{c}\varepsilon_{\mathrm{cu}} \\
\%\end{array}$ & $\alpha$ & $\begin{array}{c}\alpha \\
\text { (fórmula) }\end{array}$ & $\beta$ & $\begin{array}{c}\beta \\
\text { (fórmula) }\end{array}$ & $\alpha \cdot \beta$ & $\begin{array}{c}\alpha \cdot \beta \\
\text { (fórmula) }\end{array}$ \\
\hline C20 a C50 & 3,5 & 0,850 & 0,827 & 0,800 & 0,832 & 0,680 & 0,688 \\
\hline $\mathbf{C 5 5}$ & 2,9 & 0,835 & 0,814 & 0,793 & 0,804 & 0,662 & 0,654 \\
\hline $\mathbf{C 6 0}$ & 2,8 & 0,820 & 0,810 & 0,787 & 0,799 & 0,645 & 0,647 \\
\hline $\mathbf{C 7 0}$ & 2,6 & 0,790 & 0,802 & 0,773 & 0,788 & 0,610 & 0,632 \\
\hline $\mathbf{C 8 0}$ & 2,4 & 0,760 & 0,791 & 0,760 & 0,776 & 0,578 & 0,614 \\
\hline
\end{tabular}

\section{3 - CONCRETO COM FIBRAS}

O concreto de alta resistência sob compressão, apresenta uma ruptura frágil. O ramo descendente da curva Tensão x Deformação apresenta ductilidade reduzida. Isto, segundo KÖNIG(1996), se deve à diferença no desenvolvimento da fissuração entre o Concreto de Alta Resistência e o Concreto Convencional. No CAR as fissuras se desenvolvem também através dos agregados, resultando uma superfície de fratura relativamente lisa e com baixa ductilidade. É possível um aumento na ductilidade confinando o concreto com armadura lateral, com armadura longitudinal, ou ainda, adicionando-se fibras ao concreto.

\subsection{1 - DEFINIÇÃO}

O concreto reforçado com fibras é o concreto feito de cimento hidráulico contendo finos ou finos e agregados graúdos e fibras descontínuas discretas, segundo a definição do ACI 544.1R-86 e BENTUR \& MINDESS(1990).

Historicamente, segundo o ACI 544.1R-82 as fibras têm sido usadas para reforçar materiais frágeis há muito tempo; palhas eram usadas para reforçar os tijolos, fios de crina de cavalo eram usados para reforçar o emboço e, mais recentemente, fibras de amianto são usadas para reforçar cimento portland. Atualmente, compósitos reforçados com fibras estão sendo usados em uma grande 
variedade de aplicações, segundo BALAGURU \& SHAH(1992), BENTUR \& MINDESS(1990), AGOPYAN(1991), FIGUEIREDO(1997) e ACI 544.1R-86.

A maioria das experiências com fibras tem sido com misturas usando agregados comuns e cimento portland. Os métodos de mistura, moldagem, cura e acabamento para o concreto reforçado com fibras de aço têm sido desenvolvidos particularmente para uso em pavimentos.

As fibras são produzidas em aço, plástico, vidro e materiais naturais em várias formas e tamanhos. Podem ser de seção circular, retangular, meio-círculo, irregular ou seção transversal variável, lisas ou onduladas, e de vários tamanhos; algumas fibras e suas propriedades estão listadas na tabela 2.2.

Um parâmetro numérico conveniente para descrever as fibras metálicas, chamado relação de aspecto, usado para descrever sua geometria, é definido pelo quociente do comprimento da fibra e seu diâmetro. Se a seção transversal não for circular, adota-se o diâmetro da seção circular equivalente, de mesma área. Algumas relações de aspecto típicas, conforme o ACI 544.4R-88, ficam entre 30 e 150 e os comprimentos de $6,4 \mathrm{~mm}$ a $76 \mathrm{~mm}$.

Uma grande variedade de fibras de propriedades mecânicas, físicas e químicas diferentes têm sido usadas como reforço de matrizes cimentícias. Os materiais cimentícios sem armadura são caracterizados pela baixa resistência e deformação à tração, isto é, são materiais frágeis. Eles requerem armaduras para serem utilizados com segurança na construção civil. Estas armaduras têm sido usadas, desde o século XIX, com barras de aço contínuas, que são colocadas na estrutura para suportarem as tensões de tração oriundas da ação de momento fletor e força cortante.

As fibras, por outro lado, são descontínuas e são distribuídas aleatoriamente pela matriz cimentícia. Entretanto, tendem a ter espaçamento menor entre elas do que as barras de armadura convencional, sendo melhores no controle da fissuração.

Deste modo, as armaduras convencionais são usadas para aumentar a capacidade resistente dos elementos estruturais em concreto quanto às tensões de tração, e as fibras são mais efetivas para o controle da fissuração. 
Tabela 2.2 - Propriedades das Fibras (BENTUR \& MINDESS(1990))

\begin{tabular}{|c|c|c|c|c|c|}
\hline Fibra & $\begin{array}{c}\text { Diâmetro } \\
(\mu \mathbf{m})\end{array}$ & $\begin{array}{c}\text { Massa } \\
\text { Específica }\end{array}$ & $\begin{array}{c}\text { Módulo de } \\
\text { Elasticidade } \\
\text { (GPa) }\end{array}$ & $\begin{array}{c}\text { Resistência } \\
\text { à Tração } \\
\text { (GPa) }\end{array}$ & $\begin{array}{c}\text { Alongamento } \\
\text { até a Ruptura } \\
(\%)\end{array}$ \\
\hline Aço & $5-500$ & 7,84 & 200 & $0,50-2,00$ & $0,50-3,50$ \\
\hline Vidro & $9-15$ & 2,60 & $70-80$ & $2,00-4,00$ & $2,00-3,50$ \\
\hline \multicolumn{6}{|l|}{ Amianto } \\
\hline - Crocidolite & $0,02-0,40$ & 3,40 & 196 & 3,50 & $2,00-3,00$ \\
\hline - Chrysolite & $0,02-0,40$ & 2,60 & 164 & 3,10 & $2,00-3,00$ \\
\hline $\begin{array}{l}\text { Polipropileno } \\
\text { Fibrilada }\end{array}$ & $20-200$ & 0,90 & $5-77$ & $0,50-0,75$ & 8,00 \\
\hline $\begin{array}{l}\text { Aramid } \\
\text { (Kevlar) }\end{array}$ & 10 & 1,45 & $65-133$ & 3,60 & $2,10-4,00$ \\
\hline $\begin{array}{l}\text { Carbono } \\
\text { (Alta } \\
\text { Resistência) }\end{array}$ & 9 & 1,90 & 230 & 2,60 & 1,00 \\
\hline Nylon & - & 1,10 & 4,00 & 0,90 & $13,00-15,00$ \\
\hline Celulose & - & 1,20 & 10 & $0,30-0,50$ & - \\
\hline Acrílico & 18 & 1,18 & $14-19,50$ & $0,40-1,00$ & 3,00 \\
\hline Polietileno & - & 0,95 & 0,30 & $0,70 \times 10^{-3}$ & 10,00 \\
\hline $\begin{array}{ll}\text { Fibra de } \\
\text { Madeira }\end{array}$ & - & 1,50 & 71 & 0,90 & - \\
\hline Sisal & $10-50$ & 1,50 & - & 0,80 & 3,00 \\
\hline $\begin{array}{l}\text { Matriz de } \\
\text { Cimento } \\
\text { (para } \\
\text { comparação) }\end{array}$ & - & 2,50 & $10-45$ & $3,70 \times 10^{-3}$ & 0,02 \\
\hline
\end{tabular}


Em função das diferenças quanto ao reforço do concreto com armaduras ou com fibras, há certas aplicações nas quais o uso das fibras é melhor que o uso das barras convencionais, e BALAGURU \& SHAH(1992) citam alguns casos:

- peças esbeltas, nas quais as barras de aço não podem ser usadas e portanto as fibras seriam a armadura principal. Este material seria composto com adição de fibras em volumes superiores a 5\%. Nestas aplicações as fibras agem para aumentar a resistência e a tenacidade do compósito, como mostrado na fig. 2.5;

- componentes que devem suportar ações ou deformações localizadas, como túneis, canais, galerias e etc.;

- componentes nos quais as fibras são adicionadas para controlar a fissuração induzida por umidade ou variações de temperatura, como em lajes e pavimentos, sendo que nestas aplicações as fibras são adicionadas como reforço secundário para fins específicos.

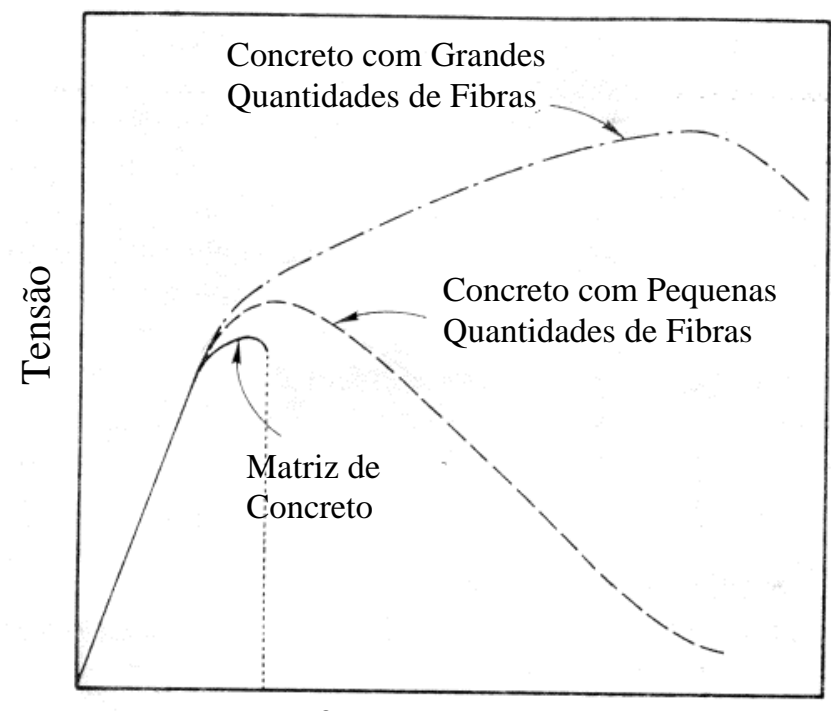

Deformação

FIGURA 2.5 - Curvas Tensão x Deformação para Concretos com Grandes e Pequenas Quantidades de Fibras (BALAGURU \& SHAH(1992))

Os principais problemas encontrados nos primeiros estágios de uso do material foram dificuldades na mistura e trabalhabilidade. Para grandes volumes de fibras são formados empolamentos durante o processo de mistura. O tamanho do 
agregado graúdo era normalmente restringido para facilitar o uso de fibras curtas e evitar o empolamento. Sempre há redução na trabalhabilidade do concreto com a adição de fibras e isto tende a afetar a sua qualidade durante a moldagem, especialmente para grandes quantidades.

No começo, o concreto reforçado com fibras era usado para pavimentos e pisos industriais. Mas, atualmente, o compósito de cimento reforçado com fibras tem grande variedade de aplicações, incluindo pavimentos para rodovias, estruturas de pontes, túneis, obras hidráulicas, estruturas resistentes a explosões e etc..

A grande dificuldade no manuseio do CRF requer mais planejamento e mãode-obra especializados, que os procedimentos de construção com concretos convencionais.

O concreto reforçado com fibras é usualmente especificado, segundo o ACI 544.3R-93, pela resistência, que pode ser à tração, à compressão ou à flexão, e quantidade de fibras, mas atualmente, a sua definição se dá pelo índice de tenacidade.

Tenacidade é a propriedade dos corpos que consomem grande energia de deformação antes de se romperem. É representada pela área sob a curva forçadeslocamento. Índice de tenacidade é uma função desta área e da área da curva até o ponto que representa a primeira fissura (ponto até o qual a curva força-deslocamento se torna não-linear). A tenacidade deve ser especificada para ajudar a definir o desempenho desejado para o $\mathrm{CRF}$, para o uso onde a absorção de energia pósfissuração é importante.

Usualmente, a resistência à flexão é especificada para aplicações em pavimentos e a resistência à compressão é dada para outras aplicações estruturais. Em geral a adição de fibras não aumenta a resistência à compressão mas aumenta a deformação última por compressão. Esta afirmação encontrada no ACI 544.3R-93, não coincide com os resultados obtidos neste trabalho. Talvez se deva ao fato de que o aumento da deformação por compressão seja em peças de concreto com adições de altas taxas de fibras.

Portanto, especificando a resistência à compressão fornece-se guias gerais para o proporcionamento do concreto. $\mathrm{O}$ aumento das outras propriedades do 
compósito, como a resistência à flexão, tenacidade, aumento na capacidade de deformação por tração ${ }^{5}$ e resistência à fissuração, se deve à adição das fibras.

A quantidade de fibras que pode ser usada sem perda inaceitável de trabalhabilidade depende das condições de moldagem, do arranjo da armadura convencional, da forma das fibras e da relação de aspecto (L/d) e do tipo e quantidade de aditivo redutor de água.

\subsection{2 - PROPRIEDADES MECÂNICAS DO CONCRETO REFORÇADO COM FIBRAS}

Neste item serão apresentados alguns conceitos básicos e algumas propriedades mecânicas do concreto com fibras, tais como interação fibra-matriz e comportamento do concreto com fibras submetido à tração, flexão e compressão.

\subsubsection{1 - Interação Fibra-Matriz}

A interação entre a fibra e a matriz é a propriedade fundamental que afeta o desempenho do compósito de cimento e fibras. Um entendimento desta interação é necessária para estimar a contribuição e previsão do comportamento do compósito. Uma variedade de fatores estão envolvidos, e a seguir apresentam-se os parâmetros principais, segundo BALAGURU \& SHAH(1992), que afetam esta interação:

- Condição da matriz: fissurada ou não-fissurada;

- Composição da matriz;

- Geometria da fibra

- Tipo da fibra: por exemplo, metálica, polimérica, mineral, ou natural;

- Características da superfície da fibra;

- Rigidez da fibra em comparação com a rigidez da matriz;

- Orientação das fibras: alinhadas ou distribuídas aleatóriamente;

- Quantidade de fibras adicionadas;

- Velocidade de carregamento;

- Durabilidade das fibras no compósito.

\footnotetext{
${ }^{5}$ Deformação por tração medida nos ensaios de compressão diametral.
} 
Em compósitos com matrizes frágeis, o efeito de transferência de tensão para as fibras deve ser considerado para os casos de pré-fissuração e pós-fissuração, mesmo que os processos possam ser diferentes nesses dois casos. Antes de acontecer qualquer fissuração, a transferência de tensões elásticas é o mecanismo dominante, e os deslocamentos longitudinais da fibra e da matriz na interface são geometricamente compatíveis. A tensão desenvolvida na interface é a tensão de cisalhamento que faz a distribuição da ação externa entre a fibra e a matriz (desde que elas tenham módulo de elasticidade diferentes), mas as deformações destes dois componentes permanecem as mesmas. A distribuição da tensão de cisalhamento na fase elástica ao longo da interface fibra-matriz não é uniforme.

Nas matrizes que ainda não sofreram fissuração, quando a ação é aplicada no elemento, parte da ação é transferida para as fibras ao longo da sua superfície. Por causa da diferença de rigidez entre a fibra e a matriz, tensões de cisalhamento se desenvolvem ao longo da superfície da fibra. Esta tensão de cisalhamento ajuda na transferência dos esforços da matriz para a fibra. Se a fibra é mais rígida que a matriz, a deformação ao longo da fibra será menor, como é mostrado na fig. $2.6 \mathrm{~b}$ e 2.6c. Este tipo de situação ocorre com fibras metálicas e minerais. Se o módulo de elasticidade da fibra é menor que o módulo de elasticidade da matriz, então a deformação ao redor da fibra será maior. Isto ocorre em compósitos com fibras poliméricas e algumas fibras naturais.

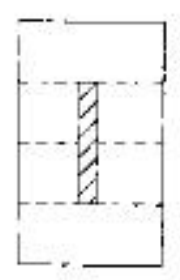

(a)

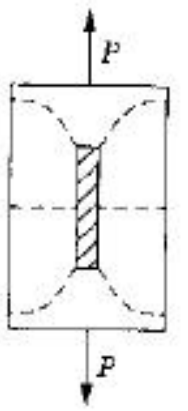

(b)

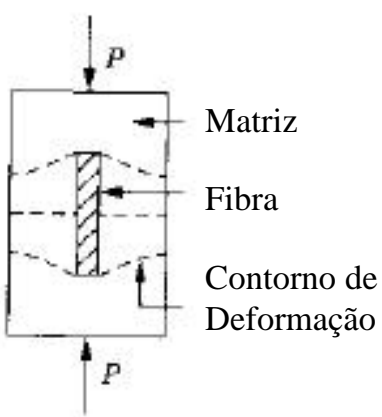

(c)

FIGURA 2.6 - Interação Fibra-Matriz Com a Matriz Não Fissurada: a)Descarregada; b)Submetida à Tração e c)Submetida à Compressão. BALAGURU \& SHAH(1992) 
As fibras são distribuídas aleatóriamente nas três dimensões, no caso de estruturas de concreto reforçado com fibras. Em quase todos os casos há interação entre as fibras, aumentando a complexidade do problema das deformações das mesmas. No entanto, modelos matemáticos para uso em aplicações práticas ainda estão em estágio de desenvolvimento.

Baseado no comportamento do compósito, observou-se que as fibras contribuem para aumentar sua resistência e rigidez. A quantidade e a natureza da contribuição dependem do tipo da fibra, do volume adicionado e das propriedades da matriz. Por exemplo, um compósito contendo $10 \%$ de taxa volumétrica de fibras de aço tem aumento de resistência à compressão de cinco vezes, enquanto que para um compósito com adição de menos de $2 \%$ de fibras, o aumento na resistência é desprezado.

A interação da fibra com a matriz, quando esta última está fissurada, também é descrita por BALAGURU \& SHAH(1992). Quando o compósito com fibras está sob tensões de tração (fig. 2.6b), ao atingir um certo estágio, a matriz fissura. Uma vez que a matriz está fissurada, as fibras transferem o esforço solicitante através da fissura, transmitindo este esforço de um lado para o outro da matriz. Na prática, as fibras fazem uma ponte de ligação na fissura, transferindo o esforço através da mesma. Se as fibras podem transmitir tensões através das fissuras, mais fissuras surgem ao longo do comprimento do elemento. Este estágio de tensões é chamado de estágio de fissuração múltipla. Em muitas aplicações práticas, este estágio ocorre sob condições de serviço da peça. As características da interação entre a fibra e a matriz também determinam o ponto de pico da curva tensão x deformação do compósito e o comportamento pós-pico.

Em estágios mais avançados de tensões, começa a perda de aderência, e o processo controlando a transferência de tensão vem a ser através do atrito. Neste caso há deslocamentos relativos entre a fibra e a matriz. A tensão de atrito desenvolvida é a tensão de cisalhamento, usualmente assumida uniformemente distribuída ao longo da interface fibra-matriz.

A eficiência do reforço com fibras depende da máxima tensão de cisalhamento que pode ser transferida para a fibra. 
Na prática, o maior efeito das fibras nos compósitos de CRF ocorre na fase pós-fissuração, onde as fibras fazem uma ponte de ligação através da fissura que deve se propagar na matriz frágil e deste modo prevenir colapsos com desagregação do concreto.

\subsubsection{2 - Eficiência do Reforço das Fibras}

Os compósitos consistem de fibras curtas dispersas na matriz, das quais ao menos algumas formam um ângulo com a direção das ações. A contribuição destas fibras curtas e inclinadas às propriedades mecânicas do compósito é menor que a das fibras longas orientadas paralelamente ao plano de aplicação da ação. A eficiência do reforço de fibras pode ser julgado com base em dois critérios: no aumento da resistência e no aumento da tenacidade do compósito, comparado com a matriz frágil. Estes efeitos dependem do comprimento das fibras, da orientação e da resistência ao cisalhamento fibra-matriz.

O efeito do comprimento da fibra pode ser analisado em termos do mecanismo de transferência de tensão. Um comprimento crítico $\ell_{c}$ pode ser definido como o comprimento mínimo requerido para que a tensão resistida pela fibra seja igual à sua resistência.

O tamanho da fibra com relação ao seu comprimento crítico tem influência não só na sua eficiência, mas também no modo de fratura. Um comprimento menor que o crítico é associado com a ruptura por arrancamento das fibras. Se o comprimento for maior, a ruptura da fibra acontecerá antes do seu arrancamento.

\subsubsection{3 - Comportamento do CRF submetido à Compressão}

O aumento na resistência dado pela adição de fibras metálicas ao concreto, raramente ultrapassa a relação de $25 \%$. Com o aumento do uso de fibras lisas com ganchos nas extremidades, a quantidade adicionada ao concreto é freqüentemente limitada a $0,75 \%$ ou aproximadamente $60 \mathrm{~kg} / \mathrm{m}^{3}$. Para este volume o aumento na resistência pode ser desprezado. Em casos especiais onde a taxa de fibras no concreto 
é maior que $1,5 \%$ ou $120 \mathrm{~kg} / \mathrm{m}^{3}$, pode-se esperar um aumento na resistência, a menos nos concretos de alta resistência.

Por outro lado, as fibras contribuem significativamente para a ductilidade. A adição de fibras aumenta a deformação para a ação última e resulta um ramo descendente da curva menos inclinado (fig.2.7). Além do mais, CRF pode absorver muito mais energia antes da ruptura se comparado com o concreto convencional. $\mathrm{O}$ aumento na ductilidade dado pelas fibras depende de alguns fatores, incluindo quantidade de fibras adicionadas, geometria das fibras e composição da matriz. Um aumento na quantidade de fibras resulta em aumento na capacidade de absorção de energia. Entretanto, a magnitude relativa de energia aumenta muito mais para adições que vão de taxas de 0 a $0,70 \%$, que para taxas maiores.

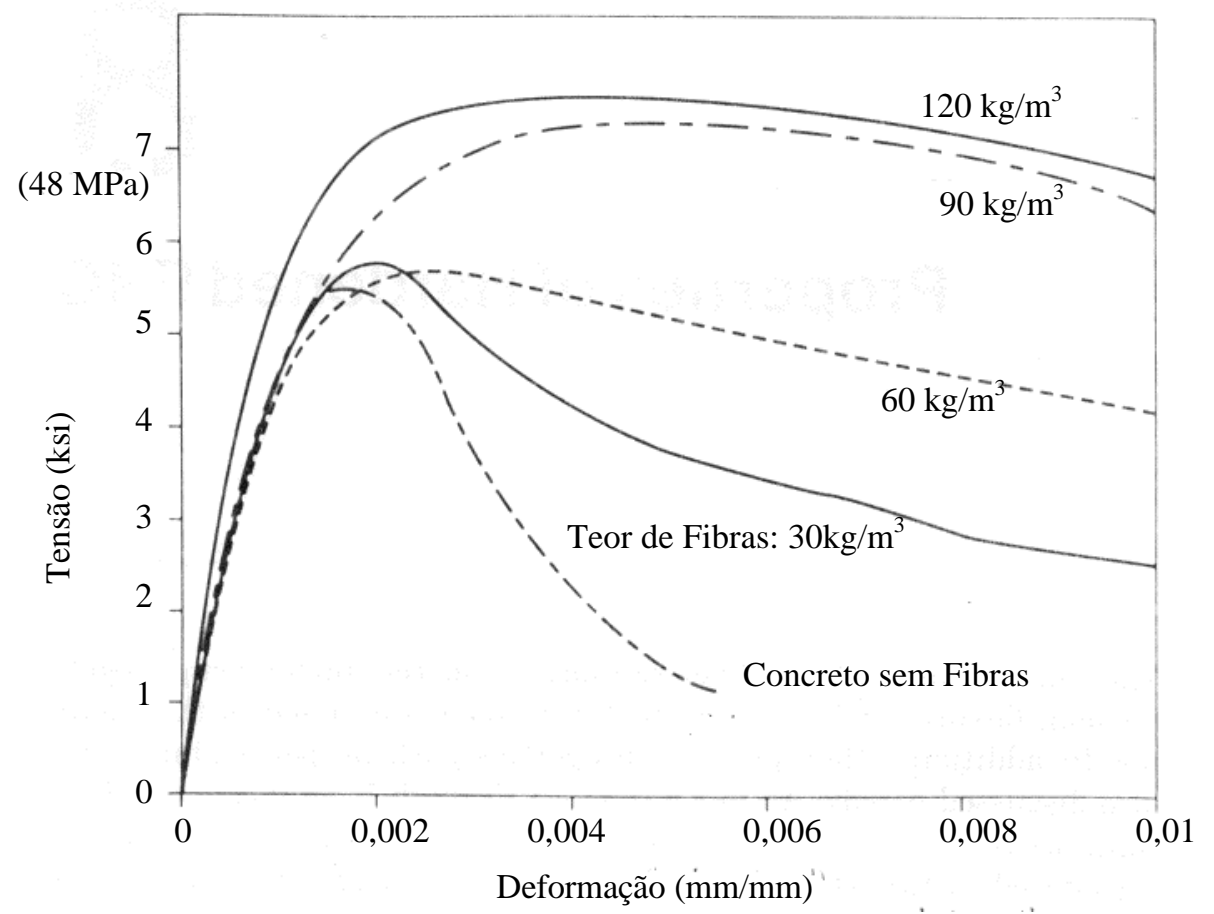

FIGURA 2.7 - Comportamento Tensão x Deformação do CRF na Compressão para Concretos de Convencionais (BALAGURU \& SHAH(1992))

Com relação à geometria das fibras, a relação de aspecto (comprimento/diâmetro) é importante para o desempenho das fibras lisas. Quando a relação de aspecto aumenta, a ductilidade do compósito aumenta desde que as fibras 
possam ser adequadamente misturadas com o concreto. No caso das fibras com ganchos nas extremidades, há ganho na absorção de energia. A relação de aspecto também vale para as fibras com ganchos nas extremidades. Entretanto, a influência não é tão significativa quanto para as fibras lisas.

A composição da matriz contribui de dois modos para a resistência e absorção de energia. $\mathrm{O}$ primeiro se refere às características de aderência com as fibras. Por exemplo, uma matriz contendo sílica ativa tende a ser mais aderente e, portanto, mais efetiva. $\mathrm{O}$ segundo modo é quanto à fragilidade da matriz, que se torna fator muito importante no comportamento do CRF.

Concretos convencionais são em geral menos frágeis que os concretos de alta resistência, e a adição de fibras torna o compósito mais dúctil. A fragilidade é mais pronunciada nos concretos contendo sílica ativa e pozolanas. Deste modo, altas quantidades de fibras são necessárias para que os concretos de alta resistência possam produzir ruptura dúctil. O contraste pode ser visto na figura 2.8 .

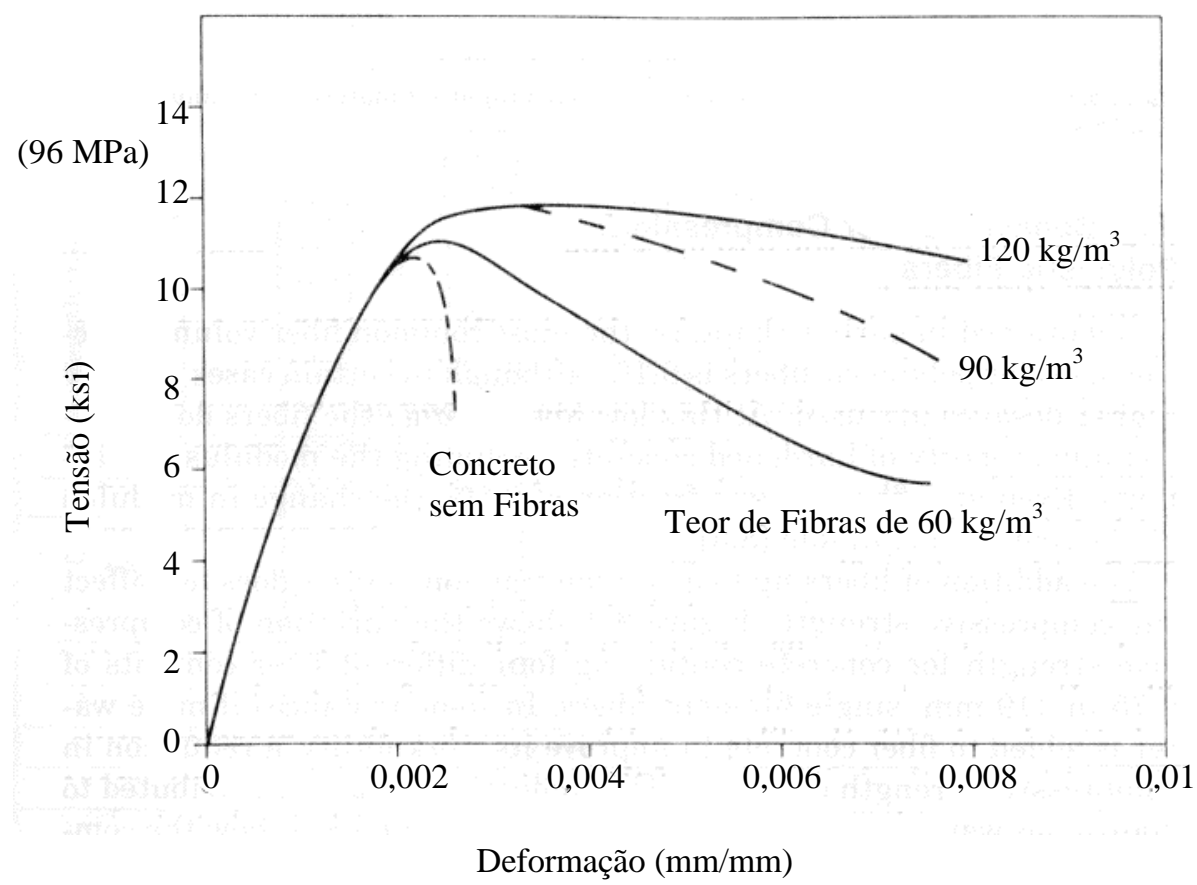

FIGURA 2.8 - Comportamento Tensão x Deformação do CRF Submetido à Compressão para Concreto de Alta Resistência (BALAGURU \& SHAH(1992)) 
A resistência à compressão parece comandar a fragilidade tanto do concreto sem fibras quanto do concreto com adição de fibras. Maiores resistências à compressão sempre resultam em rupturas mais frágeis.

A adição de taxas de $0,1 \%$ de fibras poliméricas no concreto não afeta a resistência à compressão do compósito. Para taxas maiores, se for necessário aumentar a quantidade de água no concreto por causa da trabalhabilidade, pode ocorrer uma redução na resistência à compressão. Esta redução é atribuída ao aumento da quantidade de água na mistura, e não à adição de fibras. Para taxas de $0,5 \%$, pode ocorrer uma redução de $5 \%$ a $10 \%$ na resistência, devido à incorporação de ar.

\subsubsection{4 - Comportamento do CRF submetido à Tração}

A principal razão para o uso de fibras em matrizes relativamente frágeis (sob tensões de tração), é aumentar a ductilidade da matriz. As fibras contribuem para o aumento na resistência do compósito também, entretanto, em muitas aplicações o volume adicionado de fibras é pequeno (menor que 1\%), resultando em aumento insignificante na resistência.

Nestes compósitos a capacidade de deformação da matriz é menor que a capacidade de deformação das fibras, e a matriz se rompe antes que a fibra atinja sua capacidade total. As fibras que fazem ponte de ligação na fissura, contribuem para a dissipação de energia através do processo de deslizamento e arrancamento das fibras. Nos compósitos onde a adição de fibras é alta (maior que 5\%), há um aumento significativo na resistência à tração. Depois da fissuração da matriz, o comportamento do compósito pode ser um dos apresentados à seguir:

a) O compósito se rompe imediatamente após a ruptura da matriz. A fig. 2.9a mostra este comportamento típico. Quantidades muito pequenas de fibras adicionadas à matriz podem levar a este tipo de colapso.

b) Depois da fissuração, a capacidade de suportar as ações pode cair, mas o compósito pode continuar resistindo a uma ação menor que aquela de pico (fig. 2.9b). Quando a matriz fissura, a ação é transferida do compósito (matriz mais fibras) para as fibras na interface da fissura. Por isto, a capacidade adicional de 
deformação vem da transferência de ação das fibras através das fissuras. Quando a deformação aumenta, ocorre o arrancamento das fibras da matriz, resultando em uma capacidade cada vez menor de suportar a ação. Este tipo de compósito não aumenta a resistência da matriz, mas aumenta a sua ductilidade. A área da curva tensão x deformação é uma indicação de ductilidade ou tenacidade do compósito.

c) Se a quantidade de fibras adicionadas é grande o bastante, depois da fissuração da matriz, as fibras começarão a suportar o aumento da ação. Se houver fibras suficientes através das fissuras, elas continuarão resistindo a ações maiores que aquelas que provocaram a fissuração (fig. 2.9c). A curva tensão x deformação começará a cair por causa da perda da contribuição da matriz.

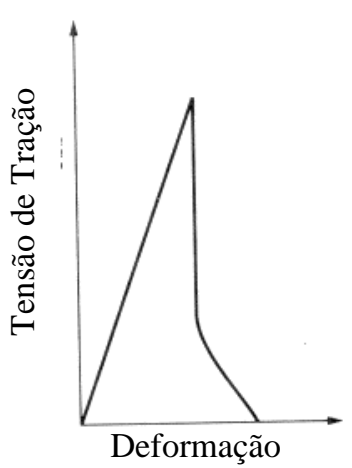

(a)

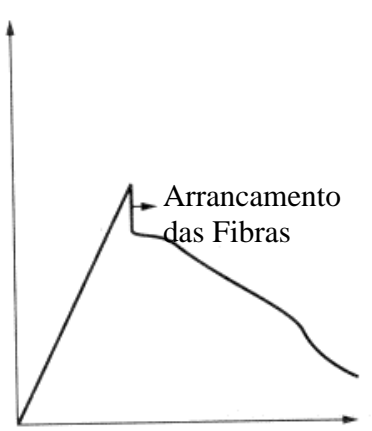

Deformação

(b)

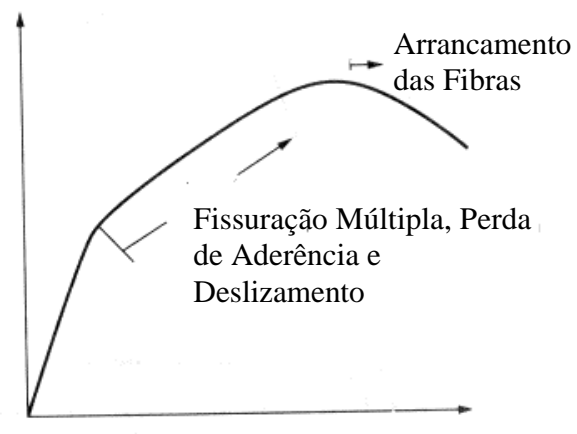

Deformação

(c)

FIGURA 2.9 - Curvas Tensão x Deformação dos Compósitos de Matrizes Frágeis Reforçados com Fibras em: a) Baixas Taxas; b) Taxas Intermediárias; e c) Altas Taxas. (BALAGURU \& SHAH(1992))

A inclinação da curva pós pico depende da quantidade de fibras adicionadas e da sua capacidade de aderência com a matriz. Quando há aumento da ação, mais fissuras surgem ao longo do comprimento do modelo. Eventualmente, quando as fibras começam a ser arrancadas da matriz, a inclinação da parte descendente da curva tensão x deformação tende a ser nula e a capacidade do compósito começa a diminuir.

Existem dois tipos de controle da resistência à tração para o concreto: tração direta e tração indireta. O ensaio de tração direta é raramente usado em concretos 
contendo agregado graúdo. $\mathrm{O}$ ensaio de tração indireta é feito em corpos-de-prova cilíndricos submetidos à compressão diametral. Cubos também são usados para este tipo de ensaio.

Em muitos casos, volumes de fibras menores que $2 \%$ adicionados ao concreto não aumentam a resistência à tração, com exceção do concreto com adição de sílica ativa. Concretos de alta resistência contendo sílica ativa têm melhor aderência com as fibras e quanto mais aderência, maior é a tendência da fibra de romper ao invés de arrancar e isto resulta em aumento na resistência à tração do compósito.

O efeito das fibras poliméricas na resistência à tração é menos pronunciado que o das fibras metálicas para concretos contendo agregado graúdo e taxas de fibras menores que $0,5 \%$. Modelos de argamassa contendo taxas de $2 \%$ a $7 \%$ de fibras poliméricas se comportam diferentemente daqueles contendo taxas menores que 0,5\%. Não há efeitos sobre a resistência à tração indireta do concreto para taxas de fibras menores que $0,2 \%$ adicionadas ao concreto. Para taxas maiores que $0,5 \%$ ou mais, há redução da resistência do concreto por causa da incorporação de ar que estas fibras promovem.

\subsubsection{5 - Comportamento do CRF submetido à Flexão}

Considere uma distribuição de tensão e deformação numa seção transversal típica de uma viga. Na parte elástica inicial do comportamento força $\mathrm{x}$ deslocamento, a relação tensão x deformação pode ser assumida linear em toda seção transversal. Se a quantidade de fibras é baixa, o comportamento da viga pode ser descrito usando a teoria clássica de flexão.

Quando a ação aumenta, as tensões máximas de tração e compressão continuam aumentando. Quando a máxima tensão de tração alcança a resistência à tração da matriz, ela fissura. Uma vez fissurada a matriz, a distribuição de tensão ao longo da seção transversal muda drasticamente então a distribuição de deformação pode ser assumida linear até que as fissuras se abram consideravelmente. Quando a matriz fissura, a solicitação suportada pela matriz é transferida para as fibras, como no caso dos modelos submetidos à tração. A principal diferença entre vigas e peças submetidas àtração pura, é a presença de um gradiente de deformação nas vigas. Se o 
número de fibras fazendo a ponte nas fissuras é menor e elas podem sustentar apenas uma pequena fração da força suportada pela matriz antes da fissuração, a capacidade do compósito diminui. Este caso é representado pela curva 1 da figura 2.10.

Se houver número suficiente de fibras para suportar uma parcela da força de tração, então a curva força $\mathrm{x}$ deslocamento deve ser parecida com a curva 2 da figura 2.10. Nos casos 1 e 2 a força que pode ser resistida pelas fibras é menor que a força resistida pela matriz não fissurada. Se as fibras puderem suportar uma força igual ou maior que aquela suportada pela matriz na zona pré-fissurada de tração, então o comportamento pode ser ilustrado pelas curvas 3 e 4 da figura 2.10. Como o volume de fibras adicionadas à matriz é raramente maior que $10 \%$, as fibras devem ser muito mais resistentes que a matriz para exibir o comportamento mostrado na curva 4.

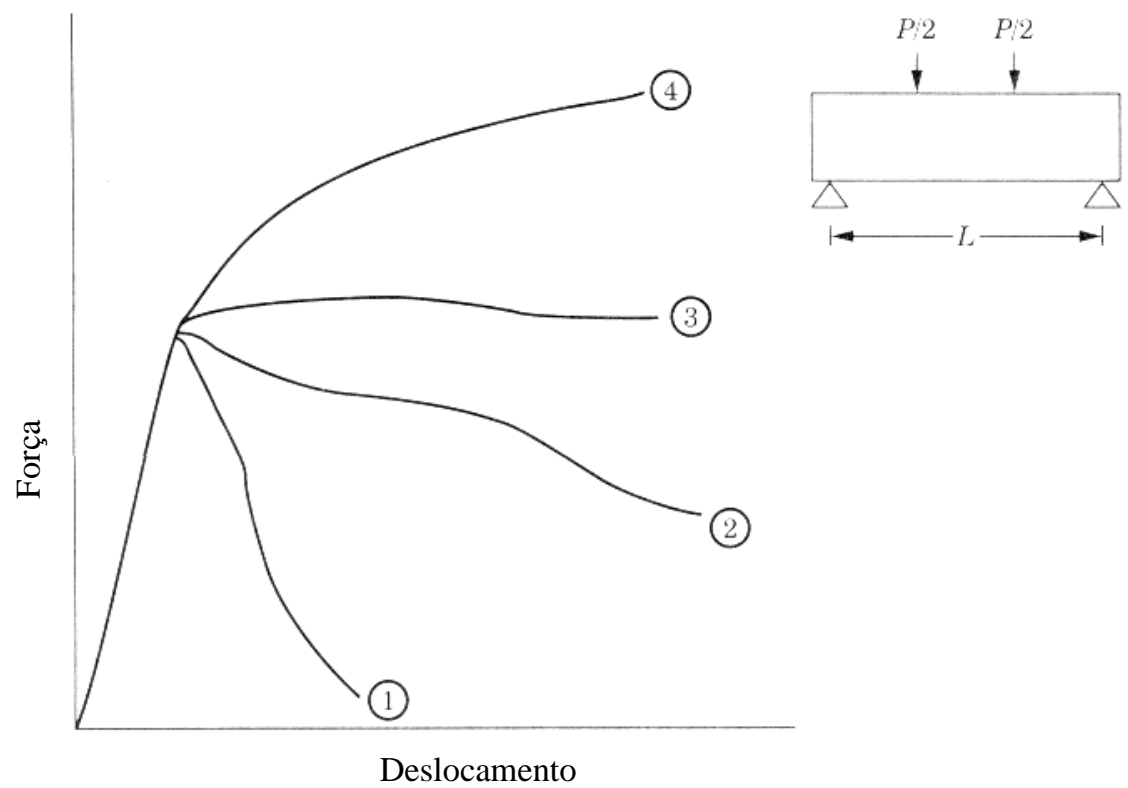

FIGURA 2.10 - Curva Força x Deslocamento Típica para Compósitos com Fibras (BALAGURU \& SHAH(1992))

$\mathrm{Na}$ maioria dos casos de aplicação do concreto com fibras, os elementos estruturais estão submetidos à flexão, portanto se torna muito importante o estudo do comportamento do CRF para estes casos. Além do mais, a adição de fibras aumenta a 
tenacidade à flexão do concreto. Ensaios são feitos usualmente em vigas de $100 \mathrm{~mm} x$ 100mm x 350mm sob a aplicação de forças em 3 seções. O aumento na resistência do concreto não é substancial para adições de taxas de fibras menores que $2 \%$, a menos dos concretos com adição de sílica ativa, pois, assim como no caso da resistência à tração, há melhor aderência da fibra com a matriz. Em todos os casos os aumentos na resistência à flexão são normalmente maiores que o aumento na resistência à compressão e na resistência à tração. A quantidade de fibras adicionadas e a relação de aspecto das mesmas são fatores muito importantes. Fibras longas tendem a se posicionar, dentro do compósito, na direção do comprimento do modelo, resultando em maior aumento na resistência.

As variáveis investigadas nos estudos dos concretos com adição de fibras poliméricas submetidos à flexão incluem a quantidade de fibras (variando de $0,075 \%$ a $0,50 \%$ ), o tipo de fibra e a composição da matriz. Estas fibras são tão efetivas quanto alguns tipos de fibras metálicas com baixa resistência à tração e se a matriz tiver alto teor de argamassa e boa aderência com a fibra polimérica, pode resultar em grande contribuição na resistência à tração.

\subsection{3 - PREPARAÇÃO DO CONCRETO REFORÇADO COM FIBRAS}

A preparação do CRF pode ser feita por mais de um método, segundo indica o ACI 544.1R-86. A escolha do método depende do trabalho requerido e das facilidades disponíveis; isto é, concreto misturado pronto, ou pequenas quantidades misturadas à mão em laboratório. Acima de tudo, é necessário ter uma dispersão uniforme do material e prevenir a segregação ou empolamento das fibras durante a mistura.

Durante a execução da mistura, a segregação do compósito ou o empolamento das fibras pode ocorrer devido a alguns fatores. O mais importante parece ser a relação de aspecto (relação do comprimento para o diâmetro equivalente). Outros fatores que devem afetar o processo são a taxa volumétrica, o tamanho dos agregados graúdos, relação água/cimento e método de mistura adotado.

Os empolamentos ocorrem durante o processo de colocação no misturador e isto pode ser eliminado pelo cuidado na seqüência de adição das fibras ou pelo uso de 
fibras coladas. O empolamento usualmente ocorre após a adição das fibras, em misturas que tenham grande quantidade de agregado graúdo ou alta porcentagem de taxa de fibras.

A relação de aspecto indicada para que se obtenha uniformidade da mistura é de 100 no máximo, mas fibras metálicas adicionadas ao compósito em taxas volumétricas acima de $2 \%$, também dificultam a trabalhabilidade da mistura.

Esta trabalhabilidade, quando medida através do cone de Abrahms (Slump Test), tem valores tão menores quanto maiores forem as taxas de fibras adicionadas ao concreto. O Slump Test não fornece subsídios para medida da trabalhabilidade do concreto com fibras mas, segundo CECCATO(1997), o abatimento do tronco de cone é eficiente para medida da consistência de concretos com teores de fibras inferiores a $80 \mathrm{~kg} / \mathrm{m}^{3}$ ( $1 \%$ de taxa volumétrica). Acima deste valor o ensaio perde a sensibilidade.

Aditivos e adições convencionais podem ser usados no CRF para preenchimento de vazios, redução de água, aumento da trabalhabilidade e controle da retração. Os superplastificantes têm sido usados na produção de concreto com fibras com baixa relação a/c para aumentar sua trabalhabilidade.

Comparadas com as do concreto convencional, essas misturas são geralmente caracterizadas pela alta quantidade de cimento, alta quantidade de agregados miúdos e agregados graúdos de dimensões menores. Por causa destes fatores, o procedimento de mistura convencional é de certa forma modificado.

\subsubsection{1 - Métodos de Mistura}

É importante que as fibras sejam dispersadas uniformemente no processo de mistura dos materiais componentes do CRF, preferivelmente antes da adição de água. Para misturas em pequenos laboratórios, é apropriado mexer as fibras em uma cesta separada. Para adições de grandes quantidades de fibras soltas de aço, as empresas de usinagem do concreto usam algumas das sequiências mostradas à seguir, indicados no ACI 544.1R-86:

a) As fibras metálicas são transportadas para o misturador por uma correia separada da correia principal, usada para os agregados e cimentos. As fibras metálicas na correia devem estar tão próximas quanto possível e em paralelo à correia 
principal para evitar a tendência ao empolamento das fibras. Portanto, as fibras são misturadas aos outros componentes do concreto somente dentro do misturador.

b) Faz-se uma combinação de fibras e agregados antes dos mesmos serem adicionados aos outros componentes do concreto, combinando as fibras e agregados na mesma correia transportadora ou rampa.

c) Faz-se a combinação de agregados miúdos com agregados graúdos no misturador. Então adicionam-se as fibras com alta velocidade do misturador ( tipicamente 12 rpm). Por último, despejam-se o cimento e a água simultaneamente ou o cimento seguido pela água mais aditivos.

d) Adicionam-se as fibras nos agregados, colocados no misturador previamente, e água. Despejam-se o cimento e a água remanescente.

e) Adicionam-se as fibras no último passo da mistura.

Para métodos manuais de lançamento de fibras usados correntemente, operários devem ser equipados com as proteções e equipamentos seguintes:

a) Luvas protetoras;

b) Garfos de jardim - preferivelmente nos tamanhos de $310 \mathrm{~mm}$ a $460 \mathrm{~mm}$;

c) Protetor para os olhos;

d) Varetas (úteis para desmanchar ninhos de fibras).

\subsection{4 - CLASSIFICAÇÃO DAS FIBRAS}

\subsubsection{1 - Fibras Metálicas}

Fibras de aço com seção transversal circular são produzidas por corte de fios, com diâmetros entre $0,25 \mathrm{~mm}$ a $0,76 \mathrm{~mm}$. Fibras de aço de seção transversal retangular com espessura variando de $0,15 \mathrm{~mm}$ a $0,41 \mathrm{~mm}$ e largura de $0,25 \mathrm{~mm}$ a 0,90mm são produzidas pelo corte de folhas ou de fios. Fibras de aço onduladas ou deformadas têm sido produzidas com ondulações em todo o seu comprimento ou deformadas apenas nas extremidades. Fibras podem ser coladas com cola solúvel em água em grupos de 10 a 30 fibras para facilitar o manuseio e mistura.

São feitas de aço inoxidável ou não. Para fibras de aço lisas, os principais fatores que controlam as propriedades do compósito são a fração do volume de fibras 
e a relação de aspecto comprimento/diâmetro (equivalente) das fibras. O limite da quantidade de fibra usada varia de $90 \mathrm{~kg}$ a $120 \mathrm{~kg}$ por metro cúbico de concreto. As relações de aspecto variam de 60 a 100.

$\mathrm{O}$ uso de fibras com ganchos nas extremidades e de aditivos redutores de água têm aumentado nas construções, pois as fibras com ganchos levam a menor consumo que as lisas e dá ao concreto o mesmo aumento de tenacidade e ductilidade e o uso de aditivos aumenta a trabalhabilidade.

Geralmente, quando usadas em elementos estruturais de concreto, fibras de aço têm a finalidade suplementar de inibir a fissuração, aumentar a resistência ao impacto ou ação dinâmica, e resistir à desintegração dos materiais. Em elementos estruturais onde a tensão de flexão ou a tensão de tração axial ocorre, como em vigas, pilares e lajes sem vigas, a armadura constituída por barras de aço deve ser capaz de resistir às tensões de tração (ACI 544.3R-93).

Resultados de pesquisas têm sido publicados sobre o uso de fibras de aço para reforços de elementos estruturais em combinação com o concreto convencional, mostrando que o aumento de resistência à flexão, o aumento da resistência ao cisalhamento e os limites de resistência à fadiga são acessíveis.

Em aplicações onde a presença de armadura contínua não é essencial para a segurança e integridade da estrutura, isto é, pavimentos de rodovias ou pisos industriais, revestimentos de túneis em camadas de concreto projetado, as fibras podem ser usadas para reduzir a espessura da seção ou aumentar o desempenho, ou ainda ambos.

\subsubsection{2 - Fibras Poliméricas}

Incluem as fibras acrílicas, de carbono, nylon, polyester, polietileno e polipropileno. As fibras poliméricas, foram criadas em 1965, entretanto, o uso em larga escala no concreto só aconteceu depois de 1970, segundo BALAGURU \& SHAH(1992). Fibras poliméricas são freqüentemente usadas em pequenos volumes (em torno de 0,1\%), para controlar a fissuração nas primeiras idades, durante o período de pega do concreto, menos que 3 horas depois da moldagem. Esta aplicação foi desenvolvida usando principalmente fibras de polipropileno; atualmente, outras 
fibras poliméricas feitas de nylon, polyester e polietileno também estão sendo usadas. Para melhorar as propriedades de endurecimento do concreto, e a resistência à fissuração causada pela retração, é necessária a adição de uma taxa volumétrica substancialmente maior que $0,1 \%$ de fibras no concreto.

O polipropileno é um polímero termoplástico que pode ser obtido pelo craqueamento do petróleo. Durante o processo de extrusão, o arranjo polimérico se torna cristalino e resulta num material muito dúctil, com alta resistência e capacidade de deformação. A superfície é hidrófuga e impermeável, mas isto reduz a aderência com a matriz de cimento. Por isso, normalmente se prefere utilizar a fibra do tipo fibrilada, que apresenta maior superfície específica, porém esta fibra pode incorporar vazios ao concreto.

O uso de fibras de carbono atraiu a atenção quando puderam ser produzidas por um custo menor usando resíduo de petróleo, segundo BALAGURU \& SHAH(1992), comparado com o alto custo das fibras de carbono convencionais. Estas fibras de carbono têm maior resistência e módulo de elasticidade mais alto quando comparada com outras fibras poliméricas.

\subsubsection{3 - Fibras Minerais}

A fibra de vidro é a fibra mineral predominantemente usada. $\mathrm{O}$ uso de amianto, que também pode ser considerado como fibra natural, está sendo severamente desencorajado por causa dos riscos à saúde humana. Países industrializados têm banido o uso destas fibras para aplicações gerais. Pesquisadores têm estudado o uso de altas taxas de volume de fibras poliméricas, de madeira, de vidro, em substituição ao amianto.

A fibra de vidro se compõe de feixes formados por vários filamentos muito finos. Com técnicas convencionais de mistura se conseguem obter compósitos com até 5\% em volume, o que é suficiente para aumentar a ductilidade e a resistência da matriz. Segundo BENTUR \& MINDESS(1990), a fibra de vidro comum é sensível ao ataque dos álcalis, por isso, foram desenvolvidas fibras especiais, mais resistentes aos seus ataques. Mesmo assim, o ataque químico não pode ser desprezado. 


\subsubsection{4 - Fibras Naturais}

Vários tipos de fibras naturais orgânicas e inorgânicas, como celulose, têm sido usadas para reforçar a matriz de cimento. O uso de fibras naturais está sendo investigado para a produção de reforços em argamassas. Fibras de celulose parecem favoráveis para o uso em larga escala. Outros tipos incluem fibras como sisal, coco, juta e bambu. Um possível problema com o uso de algumas dessas fibras naturais é a sua menor durabilidade quando submetidas ao ambiente alcalino do concreto.

As fibras vegetais despertam o interesse dos pesquisadores especialmente pela sua disponibilidade e baixo custo, tendo como principal aplicação, as habitações de baixo custo. Os problemas para sua aplicação na matriz de cimento, segundo BENTUR \& MINDESS(1990), são o baixo módulo de elasticidade e a fraca aderência, o retardo na hidratação do cimento, a instabilidade dimensional do compósito e durabilidade.

\section{4 - CONSIDERAÇÕES FINAIS}

Procurou-se neste capítulo tratar do material utilizado na pesquisa, concreto de alto desempenho com adição de fibras, de maneira que se pudesse entender o comportamento mecânico do concreto de alto desempenho, com o atributo da alta resistência, e do concreto com fibras. No próximo capítulo será feita a descrição dos ensaios realizados nesta pesquisa, a metodologia usada desde os ensaios iniciais com os materiais até os ensaios principais com os modelos de pilares. 


\section{METODOLOGIA E DESCRIÇÃO DOS ENSAIOS}

\section{1 - CONSIDERAÇÕES INICIAIS}

A metodologia experimental usada no desenvolvimento da pesquisa e que é descrita neste capítulo, compreendeu uma etapa inicial, onde se fizeram estudos para obtenção de uma dosagem para concreto de alta resistência com adição de fibras metálicas e outra para adição de fibras de polipropileno, sendo que a análise do crescimento da resistência mecânica do concreto com a idade foi feita para várias dosagens. Na etapa seguinte foram ensaiados modelos de pilares, construídos com os materiais estudados inicialmente, sob ação de compressão centrada.

\subsection{1 - OBTENÇÃO DOS CAD COM FIBRAS}

Para a obtenção do concreto utilizado nesta pesquisa, foram atendidas as seguintes etapas:

a) Escolha e caracterização dos agregados graúdo e miúdo, disponíveis na região de São Carlos, com ensaios de granulometria, massa específica e unitária, índice de forma e material pulverulento, realizados no Laboratório de Construção Civil do Departamento de Arquitetura e Urbanismo - EESC-USP; 
b) Estabelecimento de um traço inicial, baseado em trabalhos realizados anteriormente por outros pesquisadores para obtenção de um CAD;

c) Aprimoramento da argamassa do traço inicial para que à mesma pudessem ser adicionadas as fibras, sendo estudados:

- abatimento do concreto, usando ensaio com cone de Abrams, para garantir concreto com condições de lançamento nas fôrmas;

- séries de ensaios de compressão axial em corpos-de-prova cilíndricos de $100 \mathrm{~mm}$ x 200mm, com variação das taxas de fibras metálicas e de polipropileno nas proporções de $0,25 \%, 0,50 \%, 1,00 \%$, nas idades de $3,7,15$ e 28 dias, para que pudessem ser medidas a resistência média à compressão, a resistência média à tração, e o módulo de elasticidade do material aos 15 dias. Estes ensaios foram realizados no Laboratório de Mecânica das Rochas do Departamento de Geotecnia da EESC-USP.

- execução de ensaios de tração nas barras de aço que foram utilizadas como armaduras transversal e longitudinal nos modelos de pilares, realizados no Laboratório de Madeiras e Estruturas de Madeira do Departamento de Engenharia de Estruturas.

Além dos Laboratórios citados anteriormente, esteve envolvido, colaborando para o andamento da pesquisa, outro setor da Escola de Engenharia de São Carlos, a Oficina de Marcenaria, onde foram executadas as fôrmas de madeira para moldagem dos modelos.

\subsection{2 - EXPERIMENTAÇÃO COM MODELOS DE PILARES}

A seguir apresenta-se a metodologia seguida para execução dos ensaios com os modelos de pilares:

a) Projeto do modelo de pilar;

b) Projeto e execução das fôrmas;

c) Montagem das armaduras, instrumentação das barras - longitudinais e transversais - e posicionamento nas fôrmas;

d) Moldagem dos modelos, com respectivos lançamento do concreto, adensamento com mesa vibratória e cura;

e) Desmoldagem dos pilares e posicionamento no pórtico de ensaio; 
f) Controle do concreto, através dos ensaios de compressão axial com controle de força, com deformação controlada e ensaios de compressão diametral para medição da resistência média à tração, em corpos-de-prova cilíndricos de $100 \mathrm{~mm}$ x 200mm;

g) Ensaios em pilares pilotos solicitados à compressão simples, num total de 3 modelos;

h) Ensaios em 13 séries de pilares solicitados à compressão simples, mais uma série refeita, somando 28 exemplares, onde foram variadas a taxa de fibras adicionada ao concreto, o tipo de fibra e o espaçamento entre estribos. Os ensaios pilotos e definitivos foram realizados no Laboratório de Estruturas do Departamento de Engenharia de Estruturas - EESC-USP;

i) A partir dos dados obtidos pelo sistema de aquisição, elaboração de planilhas com respectivos diagramas Força x Deformação e Força x Deslocamento.

Foram escolhidas as idades de 15 e 16 dias para os ensaios dos pilares, sendo que o concreto, na data do ensaio, deveria apresentar resistência média à compressão em torno de $80 \mathrm{MPa}$.

\section{2 - MATERIAIS}

Os materiais utilizados nos ensaios preliminares e que foram usados nos ensaios principais de pilares foram caracterizados, alguns com o auxílio do Laboratório de Construção Civil, e para outros foram seguidos as especificações dos fabricantes.

\subsection{1 - CIMENTO}

Optou-se pela utilização do cimento Portland de alta resistência inicial CP V ARI, por ser um material cimentício sem adições e pela possibilidade de realização de ensaios dos modelos com idades menores. O cimento empregado nos ensaios foi recebido como doação e caracterizado pelo fabricante, segundo a NBR 6474/84, com massa específica de $3,12 \mathrm{~g} / \mathrm{cm}^{3}$.

Após o recebimento os sacos de cimento eram envolvidos em embalagens plásticas e armazenados em pilhas, afastados do piso e da parede, evitando dessa forma danos provocados pela umidade. 


\subsection{2 - SÍLICA ATIVA}

Utilizaram-se em algumas concretagens a sílica não densificada, SILMIX ND com massa específica de $2,22 \mathrm{~g} / \mathrm{cm}^{3}$, e em outras concretagens foi usada a sílica densificada, SILMIX D. Como o material foi recebido em doação, a utilização de um tipo ou outro dependeu do lote doado pela empresa, e sendo a dosagem dos materiais feita em massa, este fato não foi motivo de alteração na quantidade usada.

\subsection{3 - SUPERPLASTIFICANTE}

O superfluidificante usado era um aditivo a base de melamina sulfonada, e sua densidade era de $1,16 \mathrm{~g} / \mathrm{cm}^{3}$ obedecendo, segundo a empresa, as normas ASTM C 494 e a NBR 11768/92.

\subsection{4 - PLASTIFICANTE}

Foi usado como plastificante retardador de pega, aditivo a base de lignosulfonato de sódio, com densidade de $1,18 \mathrm{~g} / \mathrm{cm}^{3}$, conforme especificação do fabricante, isento de cloretos e obedecendo as normas ASTM C 494 e NBR $11768 / 92$.

\subsection{5 - ÁGUA}

Para a mistura do concreto foi utilizada água proveniente da rede pública de abastecimento da cidade de São Carlos.

\subsection{6 - AGREGADO MIÚDO}

Nas misturas de concreto, foi usado como agregado miúdo, areia do tipo quartzosa proveniente do rio Mogi-Guaçu, cuja análise granulométrica foi feita no Laboratório de Construção Civil da Escola de Engenharia de São Carlos - EESCUSP, seguindo as recomendações da NBR 7217/87.

Em função do módulo de finura, cujo valor era de 2,34, a areia pôde ser classificada como média. Os ensaios de caracterização efetuados foram tomados sempre como média de três determinações. A massa específica, com ensaio feito 
segundo a NBR $9776 / 87$ foi de $2,60 \mathrm{~g} / \mathrm{cm}^{3}$ e a massa unitária, com as indicações da NBR $7251 / 82$, foi de $1,46 \mathrm{~g} / \mathrm{cm}^{3}$.

\subsection{7 - AGREGADO GRAÚDO}

O agregado graúdo usado foi pedra britada de origem basáltica, da região de São Carlos. A massa específica obtida foi de $2,90 \mathrm{~g} / \mathrm{cm}^{3}$, seguindo as indicações da NBR 9776/87 para o ensaio, e a massa unitária foi de $1,45 \mathrm{~g} / \mathrm{cm}^{3}$, conforme a NBR 7251/82. A análise granulométrica, foi feita conforme recomenda a NBR 7217/87, com o módulo de finura resultando em 6,57 e o diâmetro máximo em 19mm.

O ensaio para se obter o índice de forma do agregado graúdo foi feito segundo a NBR 7809/83. A média do índice das 200 amostras utilizadas no ensaio foi de 3,2. Este índice, segundo a NBR 7211/83, está acima do indicado. Mesmo assim este material foi utilizado pela disponibilidade e por não estar influenciando a trabalhabilidade e a resistência do concreto.

A porcentagem de material pulverulento encontrada foi de $2,6 \%$ e constatouse, comparando-se com os limites indicados pela NBR 7211/83, que a porcentagem obtida $(2,6 \%)$ não comprometia o uso do agregado graúdo no concreto.

\subsection{8 - FIBRAS DE AÇO}

Foram usados três tipos de fibras de aço em função do comprimento, diâmetro e relação de aspecto nos primeiros ensaios realizados para definição da dosagem dos materiais, e as suas características podem ser vistas na tabela 3.1.

Tabela 3.1 - Fibras Utilizadas nos Ensaios Preliminares

\begin{tabular}{|c|c|c|c|}
\hline $\begin{array}{c}\text { Seção } \\
\text { Transversal }\end{array}$ & $\begin{array}{c}\text { Diâmetro } \\
(\mathbf{m m})\end{array}$ & $\begin{array}{c}\text { Comprimento } \\
(\mathbf{c m})\end{array}$ & $\begin{array}{c}\text { Relação de Aspecto } \\
(\mathbf{L} / \mathbf{d})\end{array}$ \\
\hline retangular & (equivalente) 0,67 & 2,40 & 37,47 \\
\hline circular & 1,05 & 5,00 & 47,61 \\
\hline circular & 0,85 & 6,00 & 70,59 \\
\hline
\end{tabular}




\subsection{9 - FIBRAS DE POLIPROPILENO}

Foram usadas fibras de polipropileno do tipo multifilamentos na fase de estudo do concreto, ou seja, na primeira fase do trabalho, e as suas características são mostradas na tabela 3.2 .

Tabela 3.2 - Fibras Utilizadas nos Ensaios Preliminares

\begin{tabular}{|c|c|c|c|}
\hline $\begin{array}{c}\text { Comprimento } \\
(\mathbf{c m})\end{array}$ & Título & $\begin{array}{c}\text { Resistência } \\
(\mathbf{g f})\end{array}$ & $\begin{array}{c}\text { Tenacidade } \\
(\mathbf{g f} / \mathbf{d c t e x})\end{array}$ \\
\hline 4,00 & $7,78-16,67$ & mín: 22,00 & mín: 2,85 \\
\hline
\end{tabular}

O fio do tipo multifilamentos de polipropileno é um cabo com 120 filamentos, com uma determinada densidade linear, o qual é denominada em termos têxteis de título. A unidade dctex é dada em decigramas(dg) por quilômetro. A resistência é a força com a qual um único filamento se rompe no ensaio de tração, a tenacidade é dada pela força última de tração (resistência) dividida pela densidade linear (título), e a encimagem significa a porcentagem do tratamento superficial que foi dada à fibra, que normalmente é feito com o uso de lubrificantes. Para a fibra em questão, o tratamento variou de $0,50 \%$ a $1,50 \%$. Para os ensaios de modelos de pilares, foi usada a fibra de polipropileno fibrilada, com comprimento de $6 \mathrm{~cm}$.

\subsubsection{0 - DOSAGEM E PROCEDIMENTO DE MISTURA}

Inicialmente, adotou-se como referência o traço de concreto utilizado por GIONGO, LIMA \& TAKEYA(1996), que consistia em dosagem para concreto de alta resistência com resistência média à compressão de $80 \mathrm{MPa}$. Na tabela 3.3 podem ser vistas as quantidades de materiais usados na mistura.

$\mathrm{O}$ traço foi modificado porque com a adição de fibras o concreto ficou com pouca argamassa, necessitando aumento na quantidade de areia e, consequentemente, no consumo de cimento e água. Para se conseguir a trabalhabilidade adequada do concreto, foi necessário o uso de aditivos retardadores de pega, além do superplastificante. Posteriormente constatou-se que essa adição era desnecessária. 
Tabela 3.3 - Traço Inicial Utilizado nos Ensaios Preliminares

\begin{tabular}{|l|c|}
\hline \multicolumn{1}{|c|}{ MATERIAL } & CONSUMO $\left(\mathbf{~ k g} / \mathbf{m}^{\mathbf{3}}\right)$ \\
\hline Cimento & 480,00 \\
\hline Silica ativa (10\%) & 48,00 \\
\hline Areia & 577,92 \\
\hline Brita & 1198,09 \\
\hline Superplastificante (3\%) & 17,43 \\
\hline Água & 160,60 \\
\hline Massa total & $2.482,04$ \\
\hline
\end{tabular}

Na tabela 3.4, encontram-se as quantidades de materiais usadas na dosagem modificada, onde a alteração no traço foi feita de maneira a aumentar a argamassa do concreto, para que as fibras e o agregado graúdo fossem envolvidos satisfatóriamente.

Tabela 3.4 - Traço Modificado Utilizado nos Ensaios

\begin{tabular}{|l|c|}
\hline \multicolumn{1}{|c|}{ MATERIAL } & CONSUMO $\left(\mathbf{~ k g} / \mathbf{m}^{3}\right)$ \\
\hline Cimento & 492,500 \\
\hline Sílica ativa $(10 \%)$ & 49,250 \\
\hline Areia & 715,000 \\
\hline Pedra britada & $1.025,000$ \\
\hline Superplastificante $(3 \%)$ & 17,140 \\
\hline Plastificante(0,3\%) & 1,740 \\
\hline Água (a/c=0,37) & 169,000 \\
\hline Fibra de aço(1,00\%) & 78,500 \\
\hline Fibra de aço(0,50\%) & 39,250 \\
\hline Fibra de aço(0,25\%) & 19,625 \\
\hline Fibra de polipropileno $(1,00 \%)$ & 9,000 \\
\hline Fibra de polipropileno(0,50\%) & 4,500 \\
\hline Fibra de polipropileno(0,25\%) & 2,250 \\
\hline
\end{tabular}


Foi escolhido para os ensaios subsequentes de corpos-de-prova de concreto com fibras metálicas, trabalhar com as fibras retangulares, em função do menor comprimento e melhor trabalhabilidade dada à argamassa. Na figura 3.1, mostra-se as fibras metálicas e poliméricas.
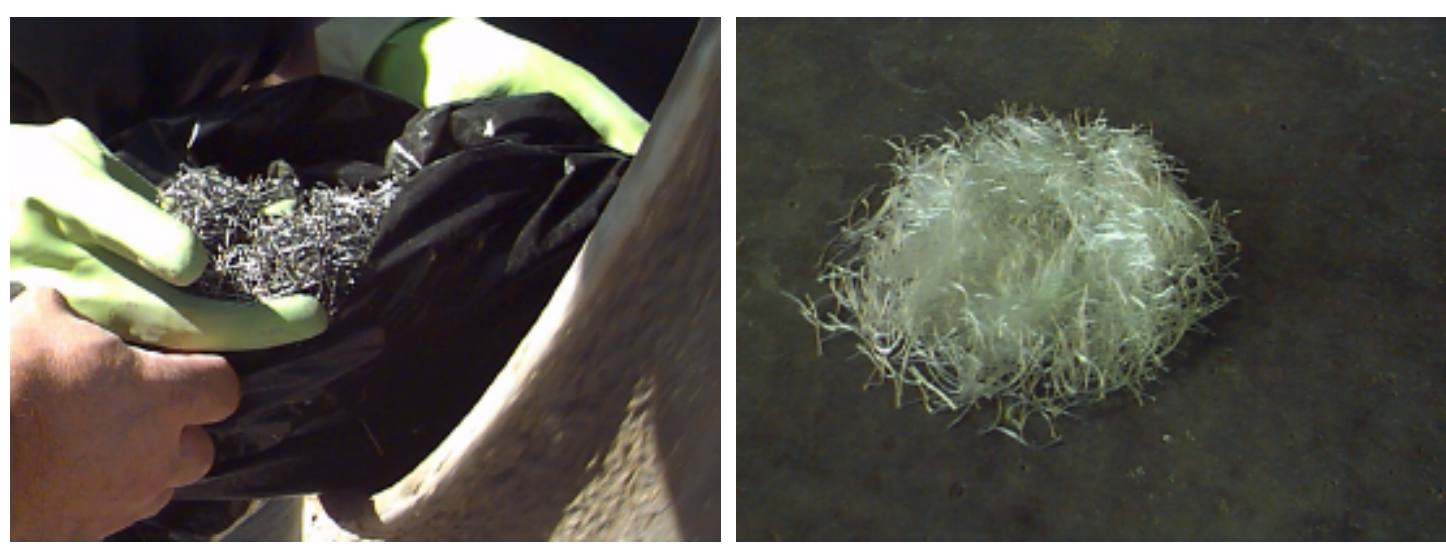

FIGURA 3.1 - Fibras Metálicas e Poliméricas

A quantidade de material foi especificada em massa. Para que pelo menos uma parcela do pó de pedra fosse retirado, deixou-se o agregado graúdo rodando a seco na betoneira por 3 minutos. Em seguida adicionaram-se $20 \%$ de água mais as fibras deixando a betoneira virar por 2 minutos. Depois foram acrescentados o cimento, a sílica ativa e $50 \%$ da água, fechando a boca da betoneira com saco plástico para que parte da sílica ativa não saísse, e deixou-se a máquina rodar por 2 minutos. Por último, foram acrescentados a areia, o superplastificante com o restante da água (30\%) e o retardador de pega, deixando a massa bater na máquina por mais 3 minutos. O tempo de mistura foi de mais ou menos 10 minutos. Esta sequência de mistura, a menos da adição de fibras, foi indicada por DAL MOLIN(1995).

Posteriormente, para os ensaios definitivos das séries de pilares optaram-se pelas fibras circulares longas, com $6,00 \mathrm{~cm}$ de comprimento. $\mathrm{O}$ motivo da troca das fibras curtas, de $2,40 \mathrm{~cm}$ de comprimento, pela mais longa, consistiu no fato que o agregado graúdo usado no concreto tinha diâmetro nominal de $19 \mathrm{~mm}$. Optou-se pelo uso de fibras com comprimento de pelo menos 3 vezes o diâmetro nominal do agregado graúdo, segundo indicação do Prof. Newton de Oliveira Pinto Jr., porque as fibras devem ter comprimento suficiente para envolver mais de um agregado dentro da matriz de concreto, e a resistência à tração das fibras escolhidas para os ensaios 
dos modelos de pilares era maior que a da fibra usada no concreto dos corpos-deprova feitos na etapa inicial do trabalho, a qual passou de aproximadamente $700 \mathrm{MPa}$ para $1100 \mathrm{MPa}$

Depois de algumas moldagens, verificou-se ser desnecessário o uso do aditivo plastificante retardador. Apenas com o superplastificante incorporado ao concreto, conseguiu-se a trabalhabilidade necessária para a moldagem dos modelos. Portanto, a quantidade de água que passou a ser introduzida no concreto foi de $170,23 \mathrm{~kg} / \mathrm{m}^{3}$.

\subsubsection{1 - CARACTERIZAÇÃO DAS ARMADURAS}

Foram utilizadas barras de aço CA-50 de diâmetros 12,5mm, como armadura longitudinal e $6,3 \mathrm{~mm}$ como armadura transversal. Nas figuras 3.2 e 3.3 observam-se os diagramas tensão x deformação obtidos em ensaio de tração em amostras retiradas das barras de aço utilizadas.

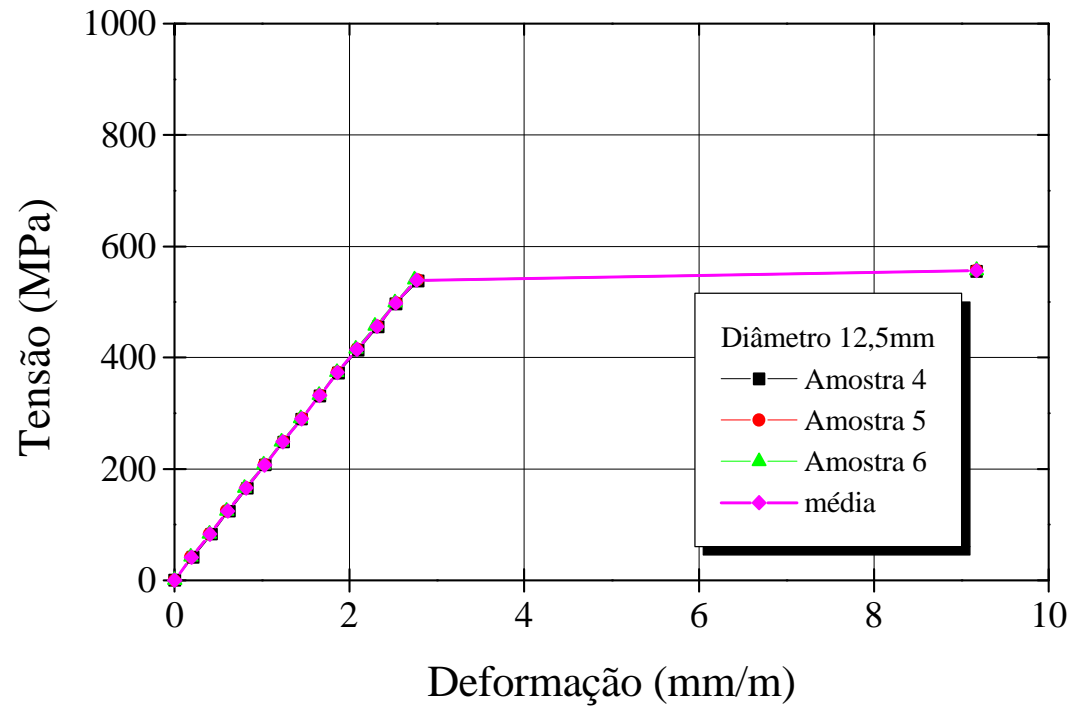

FIGURA 3.2 - Diagrama Tensão x Deformação para as Barras de 12,5mm

As barras de 12,5mm de diâmetro nominal, apresentaram resistência média de escoamento de $556 \mathrm{MPa}$ e as de $6,3 \mathrm{~mm}$, determinada com uma reta paralela à inicial, a uma deformação de 2\%o, 594,33MPa. 


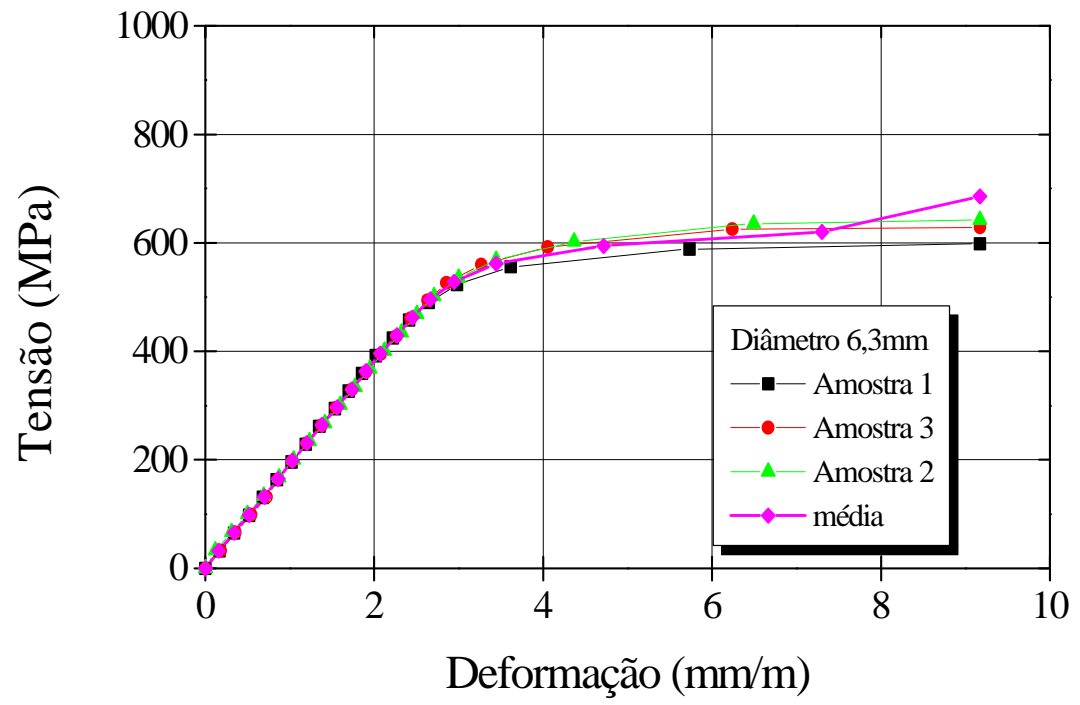

FIGURA 3.3 - Diagrama Tensão x Deformação para as Barras de 6,3mm

\section{3 - CARACTERÎSTICAS MECÂNICAS DOS CONCRETOS COM FIBRAS}

Os ensaios com o concreto contendo fibras metálicas, que serão descritos à seguir, foram relatados em dois artigos escritos no ano de 1997, sendo que um deles, GUIMARÃES, A.E.G.; GIONGO, J.S. \& LIMA, F.B.(1997), foi publicado em Anais e apresentado em sessão plenária na 39. ${ }^{\text {a }}$ REIBRAC, evento realizado pelo IBRACON em São Paulo-Brasil, e o outro, GUIMARÃES, A.E.G.; GIONGO, J.S. \& TAKEYA, T.(1998), foi publicado em Anais Complementares no Fourth International Conference on Recent Advances in Concrete Technology, evento realizado pelo CANMET/ACI em Tokushima-Japão. Além desses trabalhos, também foi elaborado relatório FAPESP (GIONGO et al.(1998)), justificando o processo número 97/00932-6, aprovado em 1998.

\subsection{1 - CONCRETO COM FIBRAS METÁLICAS}

\subsubsection{1 - Descrição dos Ensaios}

Foram moldados 15 corpos-de-prova para cada série com o objetivo de determinar a resistência média à compressão aos 3, 7, 15 e 28 dias de idade, e a 
resistência média à tração aos 15 dias. Todas as quatro séries possuíam a mesma dosagem de materiais para a mistura, com exceção da quantidade de fibras, que na série A foi usada taxa volumétrica de $1,00 \%$, na série $\mathbf{B}$ de $0,50 \%$ e na série $\mathbf{C}$ de $0,25 \%$. A série $\mathbf{D}$ foi feita sem adição de fibras.

$\mathrm{Na}$ figura 3.4 pode ser visto o concreto com fibras da série A na betoneira, com adição de $1,00 \%$ de taxa de fibras, e a sua retirada depois de 10 minutos de mistura. O concreto ficou com boa trabalhabilidade, o qual pôde ser utilizado, segundo indica o ACI 544.3R-93, o Slump Test, cujo resultado do abatimento foi de $17 \mathrm{~cm}$.
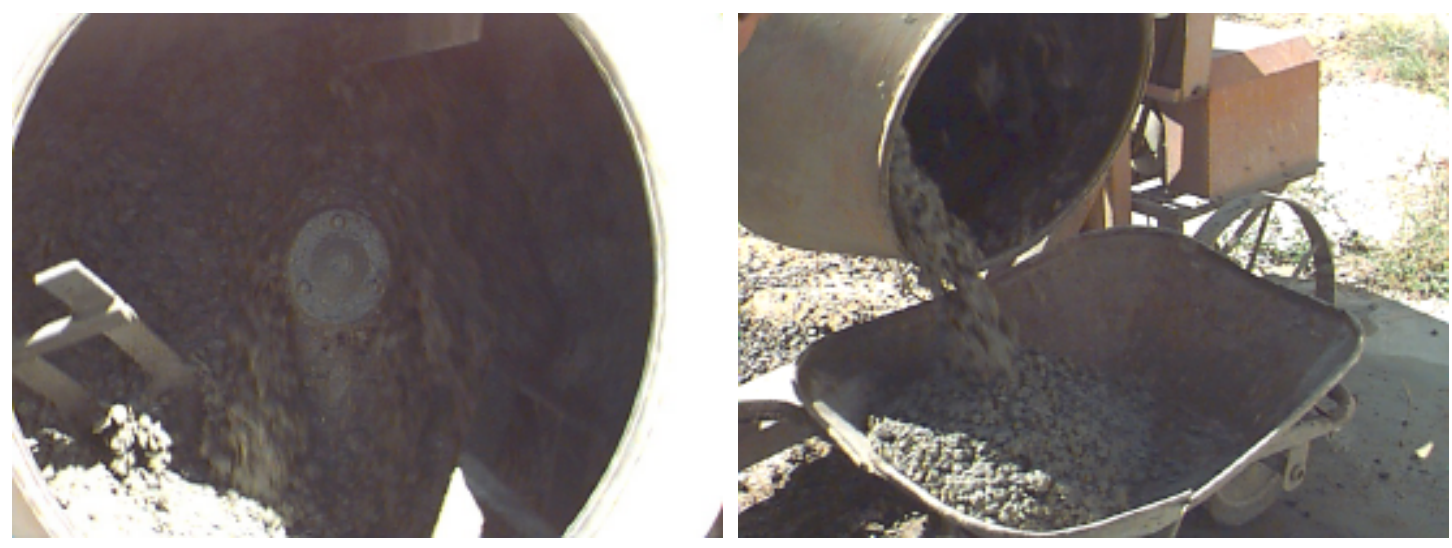

FIGURA 3.4 - Aspecto do Concreto Durante a Mistura e Lançamento

Nas moldagens dos corpos-de-prova foi utilizado vibrador de agulha para adensamento, com o concreto sendo colocado em duas camadas como pode ser visto na figura 3.5. Posteriormente foi usado mesa vibratória.

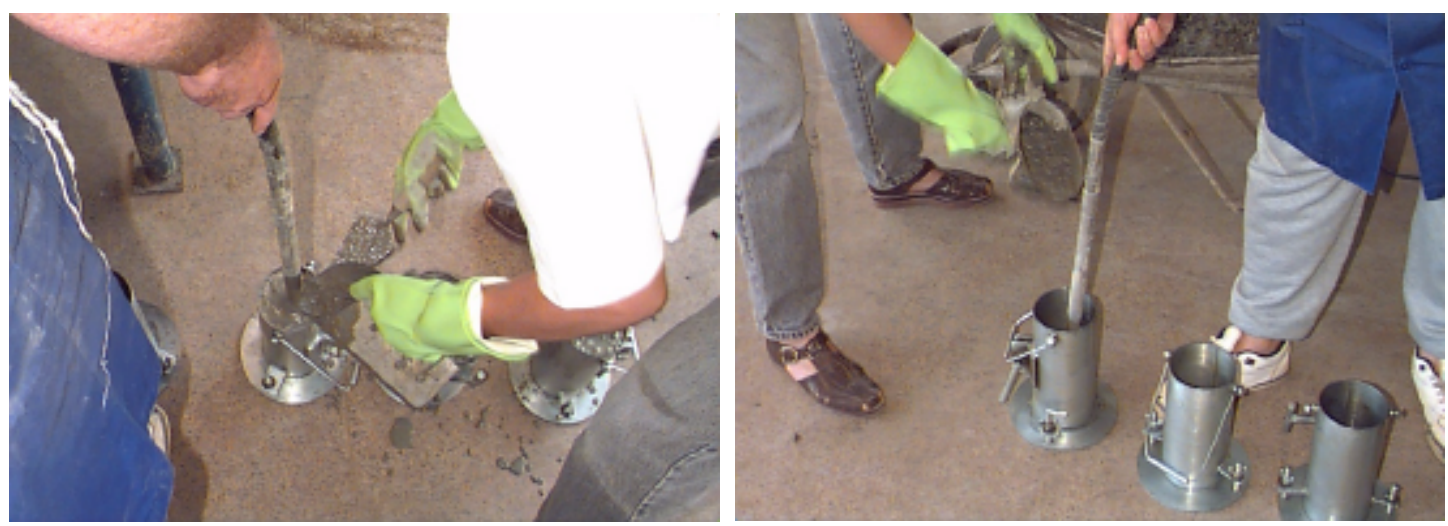

FIGURA 3.5 - Moldagem dos Corpos-de-Prova 
O concreto da série B ficou mais fluído, com abatimento de $22 \mathrm{~cm}$, medido através do Slump Test. Este valor ocorreu provavelmente devido a dois fatores: primeiro, entre a execução da mistura de uma série e outra, a betoneira foi lavada, podendo ter permanecido um pouco de água, apesar dos cuidados que foram tomados; segundo, a diminuição da quantidade de fibras, que exige menor quantidade de água na massa de concreto.

Os concretos das séries $\mathrm{C}$ e D ficaram um pouco mais secos que aqueles das séries A e B. O ambiente estava frio e úmido durante a execução das misturas A e B, e ainda havia suspeita de resquício de água na betoneira para a execução da série B. O Slump Test para a série C foi medido em três pontos, resultando uma média de abatimento de $6,27 \mathrm{~cm}$ e o concreto da série D teve um abatimento médio de $8,72 \mathrm{~cm}$.

Os corpos-de-prova das séries A e B foram moldados no mesmo dia, e após uma semana foram feitas as séries C e D.

\subsection{2 - CONCRETO COM FIBRAS DE POLIPROPILENO}

\subsubsection{1 - Descrição dos Ensaios}

Nestes ensaios seguiram-se os mesmos procedimentos usados nos ensaios do concreto com adição de fibras metálicas.

Ao todo foram 3 séries para as fibras de polipropileno, séries E, F e G. As misturas foram todas feitas com as mesmas dosagens de materiais, com exceção das taxas volumétricas de fibras, que na série $\mathrm{E}$ foi de $1,00 \%$, na série $\mathrm{F}$ foi de $0,50 \%$ e na série $\mathrm{G}$, de $0,25 \%$.

Durante a execução do concreto da série E, percebeu-se que a mistura perdeu bastante trabalhabilidade, ficando os corpos-de-prova com ninhos de fibras. Foi preciso adicionar um pouco mais de água $(445 \mathrm{~m} \ell)$, subindo a relação a/c de 0,37 para 0,40 .

Depois de retirada a massa da betoneira, percebeu-se que as fibras ficaram aderidas nas pás. O Slump Test foi nulo e o concreto ficou muito difícil de ser trabalhado, mas foi possível moldar os corpos-de-prova. Durante a moldagem, para que os corpos-de-prova pudessem ficar completamente cheios, foi necessária ajuda manual. 
A taxa de $1,00 \%$ de fibras de polipropileno é uma dosagem um pouco alta para ser adicionada ao concreto, prejudicando a sua trabalhabilidade. O usual é uma taxa de $0,25 \%$, que é pouca para aumentar a ductilidade do material. Por isso esta é uma fibra pouco utilizada em elementos estruturais onde a necessidade do aumento da tenacidade é necessária, como por exemplo em pilares. Recentemente ela tem sido usada em concretos para pavimentos, para conter a retração plástica do concreto fresco. Esta informação foi dada pelo engenheiro da empresa Camargo Corrêa Cimentos S.A., Eng. Cristovam S. C. Cunha, em visita ao Laboratório de Estruturas - EESC - USP.

Para a concretagem da série $\mathrm{F}$ não foi necessário aumentar a quantidade de água. Apesar do Slump Test ter sido quase nulo $(0,50 \mathrm{~cm})$, a moldagem dos corposde-prova foi possível, como pode ser visto na figura 3.6.

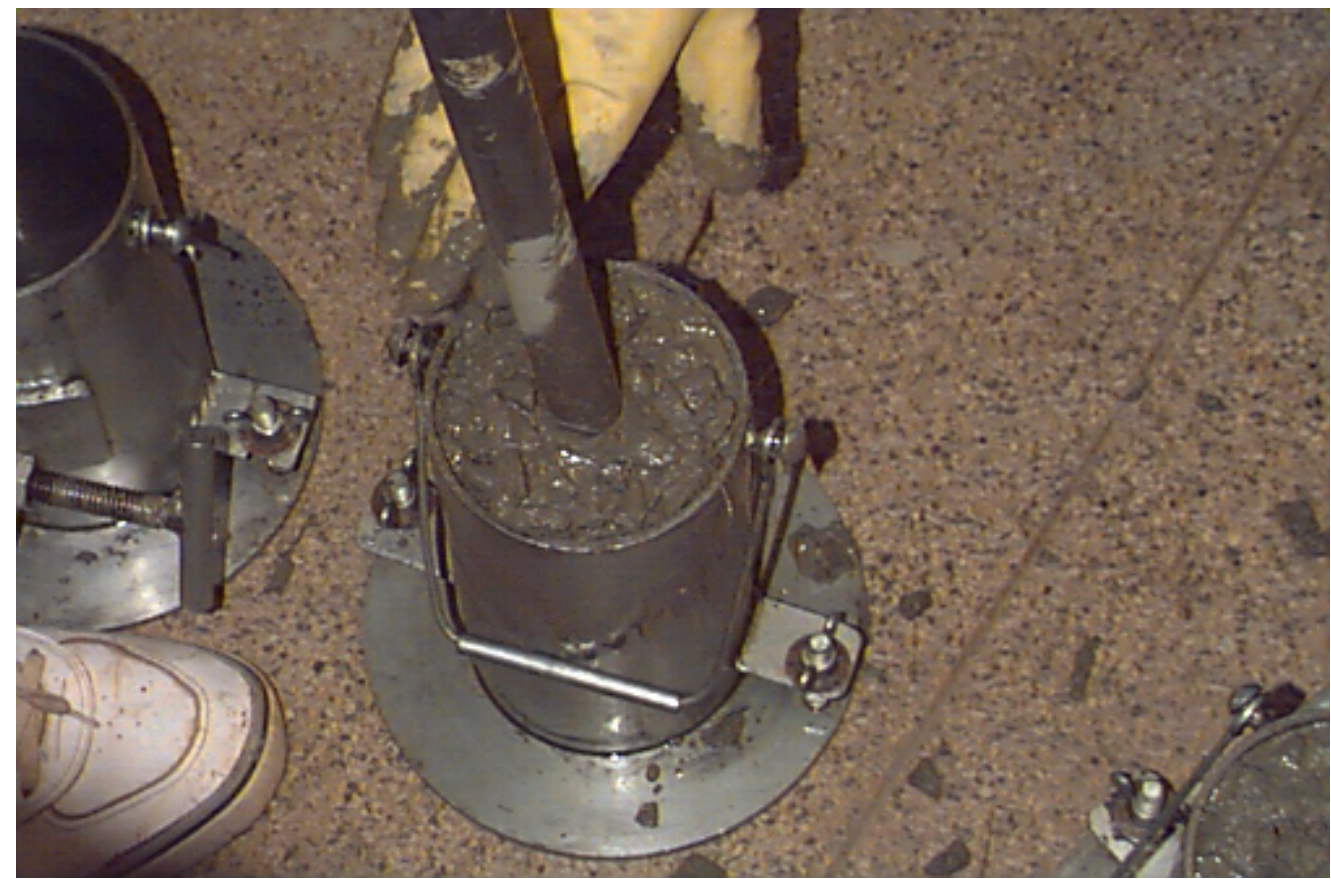

FIGURA 3.6 - Concreto com Adição de Fibras de Polipropileno

A mistura da série $\mathrm{G}$ não teve problemas quanto à quantidade de água, e o abatimento foi medido pelo Slump Test com os valores de 5,5cm; 6,2cm e 8,5cm, resultando em média de $6,73 \mathrm{~cm}$. 


\section{4 - ENSAIOS DOS PILARES}

\subsection{1 - ESTRUTURA DE REAÇÃO}

Na figura 3.7 pode ser observada uma vista geral do pórtico.

A estrutura de reação é composta de pórtico metálico convenientemente ancorado, por meio de tirantes, em laje de reação. O pórtico foi projetado pelo Professor José Jairo Sales do Departamento de Engenharia de Estruturas. É composto de 4 colunas e uma grelha horizontal fixada por meio de parafusos. A capacidade nominal é de $5.000 \mathrm{kN}$.

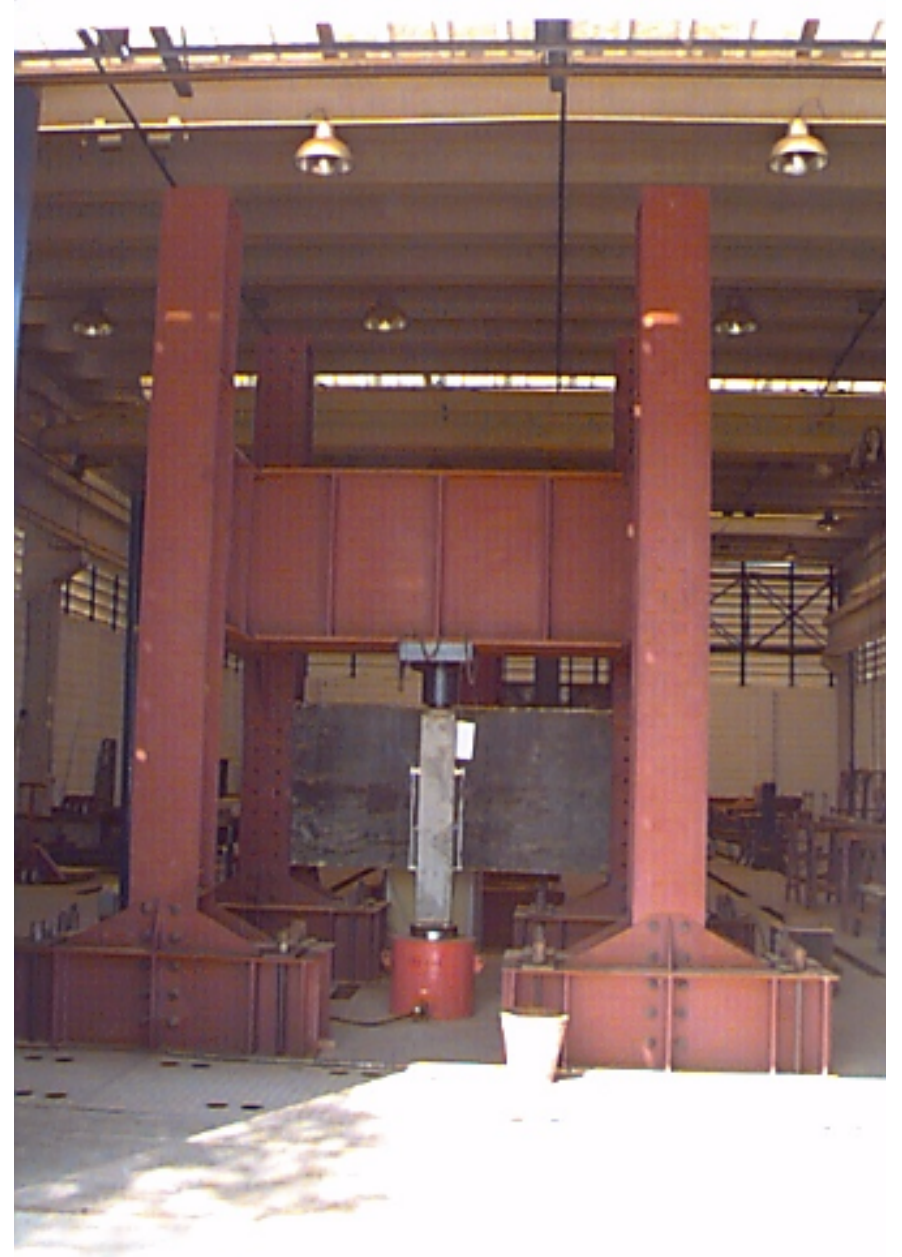

FIGURA 3.7 - Pórtico de Reação Instalado no Galpão de Ensaios do Laboratório 


\subsection{2 - ENSAIOS PILOTOS DOS PILARES}

Foram ensaiados três pilares de dimensões 200mm x 200mm x 1200mm, dois com adição de fibras metálicas ao concreto (nas taxas de 0,50\% e 1,00\%) e um terceiro com adição de fibras de polipropileno (com a taxa de $0,50 \%$ ), para que os resultados pudessem ser comparados com os apresentados por LIMA(1997) onde, pilares com as mesmas medidas utilizadas neste trabalho, foram moldados com concreto de alto desempenho sem adição de fibras.

\subsubsection{1 - Fôrmas}

Foram usadas chapas de madeira plastificada de $12 \mathrm{~mm}$ de espessura para confecção das fôrmas, cujas dimensões são descritas na figura 3.8. Ela foi projetada de modo a se fazerem as concretagens de 3 pilares de seção transversal quadrada de $200 \mathrm{~mm}$ x 200mm, na horizontal, pela facilidade de preenchimento.

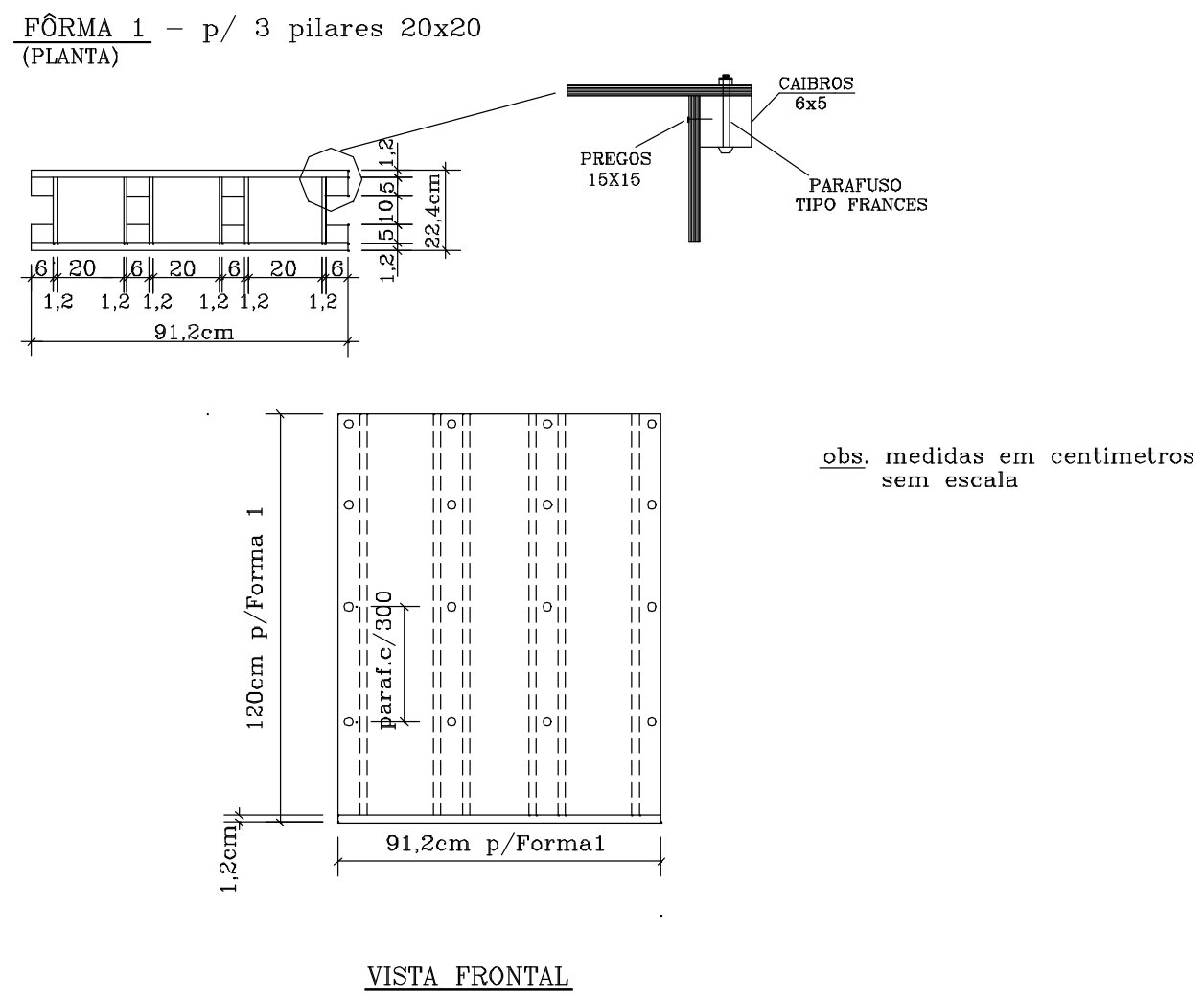

FIGURA 3.8 - Fôrma Utilizada para Moldagem dos Pilares Pilotos 


\subsubsection{2 - Armadura}

$\mathrm{Na}$ figura 3.9, pode ser visto o arranjo de armadura utilizado nas extremidades dos pilares, como armadura de fretagem, para impedir que a ruptura dos modelos acontecesse nas regiões de aplicação de força. Até as seções transversais distantes $18,5 \mathrm{~cm}$ das extremidades, posicionava-se armadura de fretagem, e nas seções contadas entre estas, posicionavam os estribos, cujo espaçamento foi variado, com a configuração escolhida sendo a mais simples e usual. Segundo CUSSON \& PAULTRE(1994), esta configuração não é efetiva no confinamento, nem no incremento de ductilidade dos elementos de concreto de alta resistência, e justamente por isso foi escolhida essa configuração, para que fosse analisado o efeito das fibras no aumento de ductilidade dos pilares.

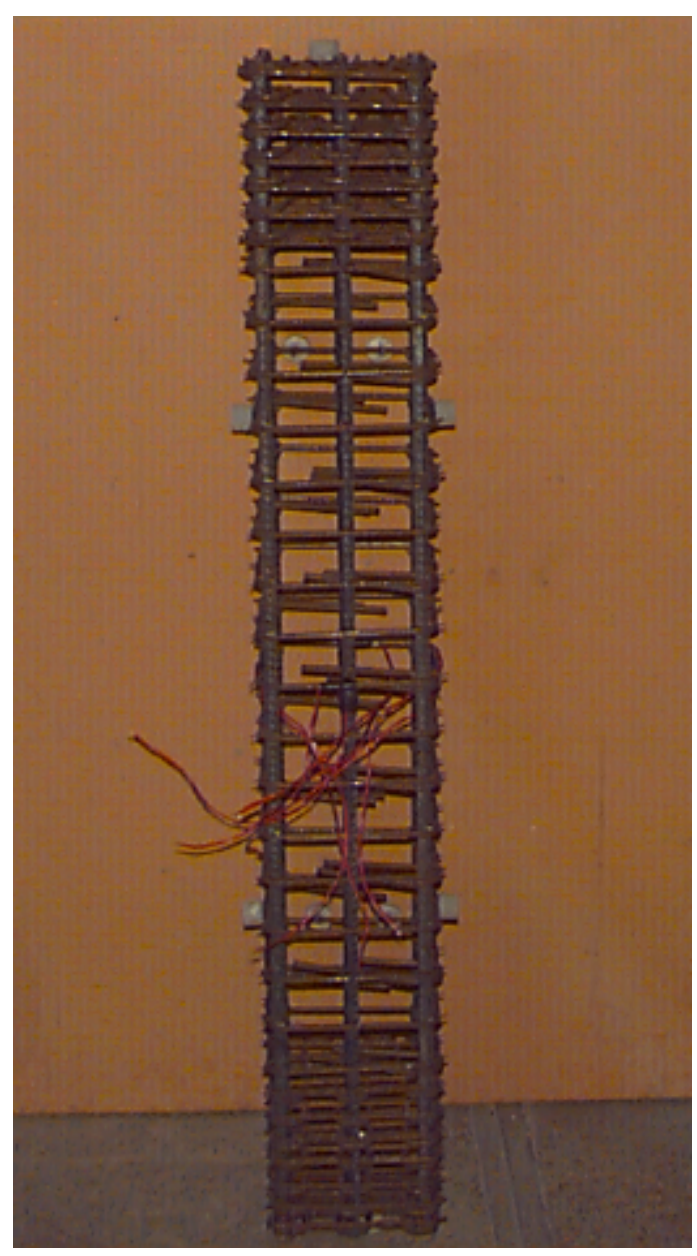

FIGURA 3.9 - Armadura de Fretagem e Estribos ao longo do Pilar 


\subsubsection{3 - Moldagem}

As moldagens dos pilares foram feitas no mesmo dia, pelo fato de se utilizar apenas uma fôrma para a concretagem. Para cada pilar foi necessário apenas uma operação de mistura do concreto. As figuras de 3.10 a 3.16 mostram a sequência de moldagem dos modelos pilotos. Foram tomados todos os cuidados para se garantir o posicionamento das armaduras dentro das fôrmas, usando-se espaçadores de argamassa e também de material plástico, mostrados na figura 3.10.

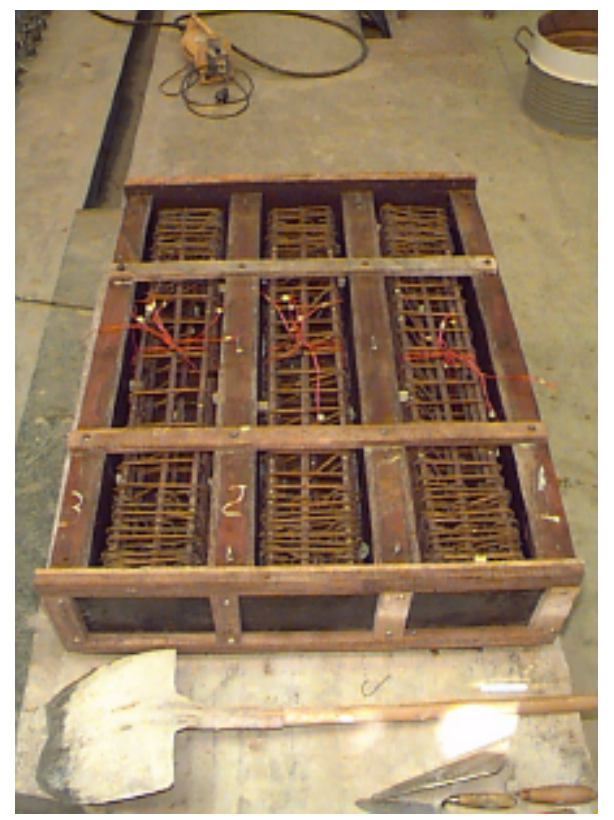

FIGURA 3.10 - Disposição das Armaduras com Espaçadores nas Fôrmas

A figura 3.11 mostra a mistura de concreto com $0,50 \%$ de fibras de polipropileno sendo retirada da betoneira.

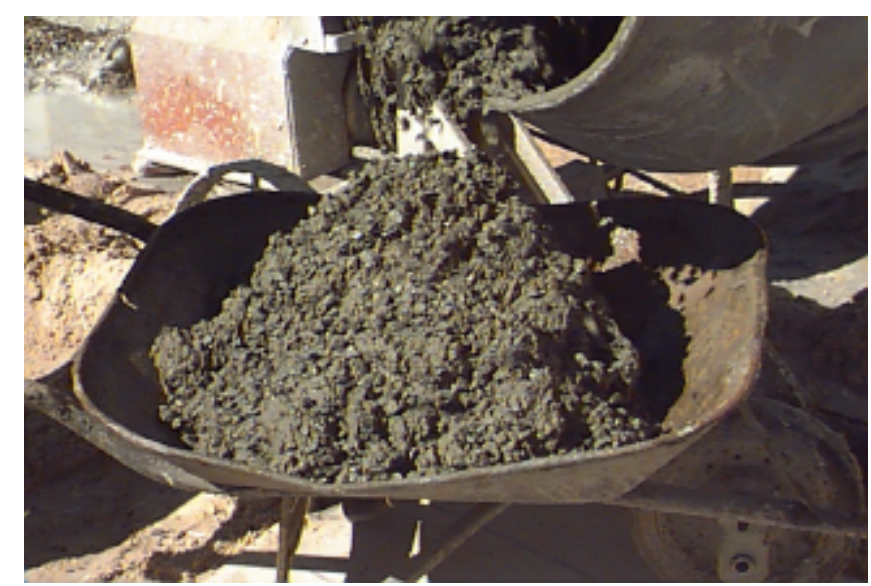

FIGURA 3.11 - Concreto com Fibras de Polipropileno (0,50\% de taxa volumétrica) 
O concreto era colocado na fôrma, disposta horizontalmente, e depois de preenchida, era iniciado o processo de adensamento ligando-se a mesa vibratória, como pode ser visto na figura 3.12 .

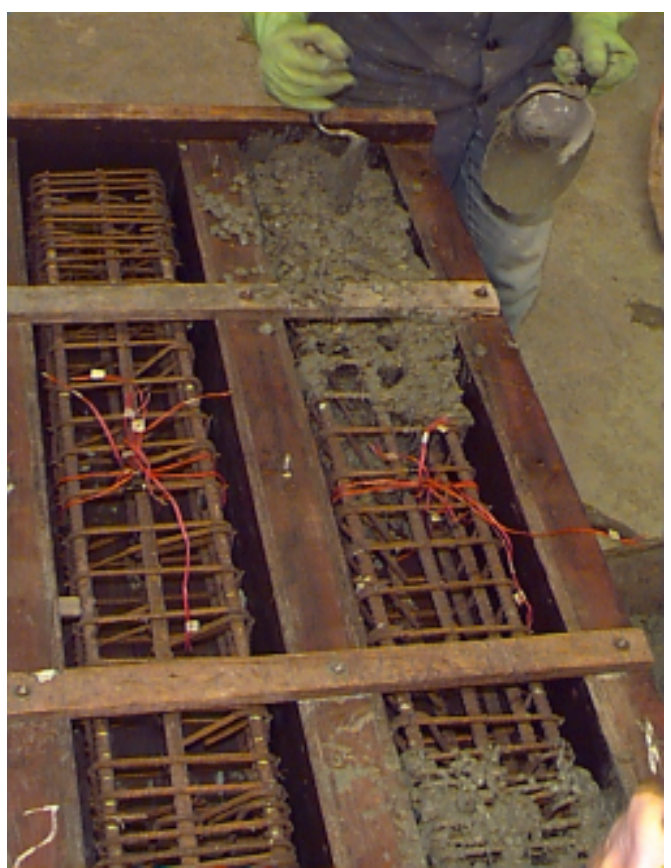

FIGURA 3.12 - Moldagem do Pilar Piloto 1

Os corpos-de-prova de $100 \mathrm{~mm}$ x 200mm foram moldados em duas camadas e adensados com a ajuda de um vibrador de agulha. Foram moldados 6 unidades para cada pilar, para controle da resistência característica à compressão aos 7 dias e 15 dias. Na figura 3.13 pode ser visto o concreto com $0,50 \%$ de fibras metálicas, sendo retirado da betoneira e colocado no carrinho de mão para o transporte até o local da moldagem.
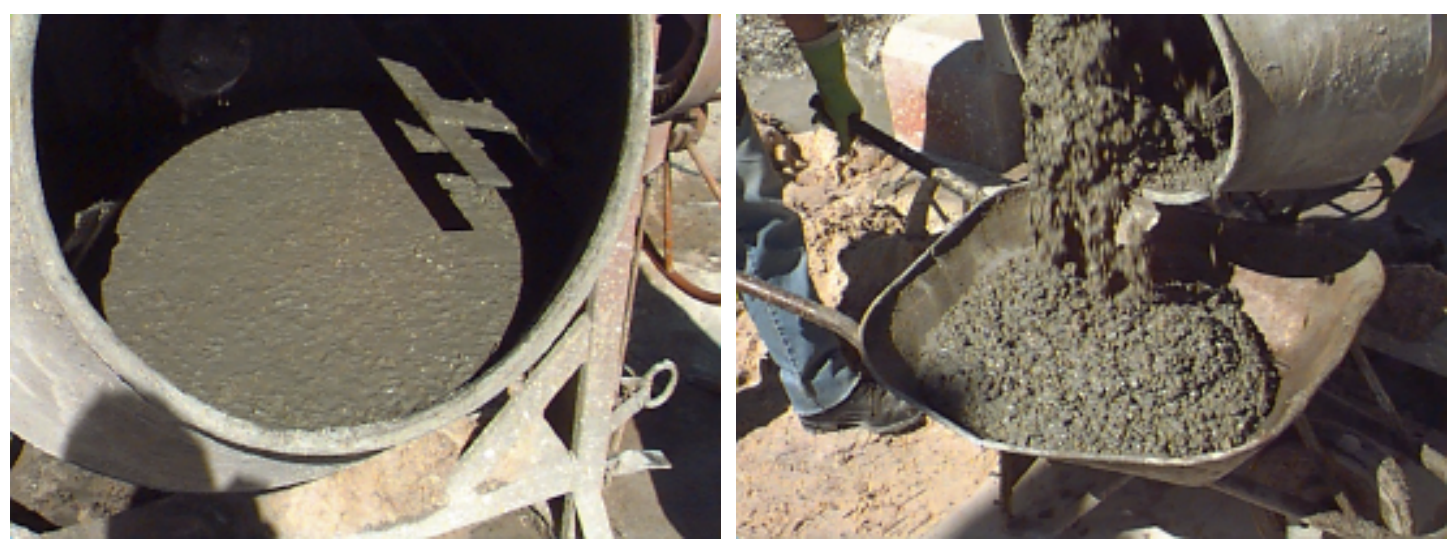

FIGURA 3.13 - Retirada do Concreto com Fibras Metálicas da Betoneira 
O adensamento dos corpos-de-prova com vibrador de agulha foi feito para os modelos pilotos. Para as séries principais, passou-se a utilizar a mesa vibratória, com o concreto sendo colocado na forma dos corpos-de-prova em três ou quatro camadas.

Devido à boa trabalhabilidade da massa, a concretagem do pilar piloto 2 pôde ser feita com facilidade, como é mostrado na figura 3.14. Após a moldagem de cada pilar, a mesa vibratória era ligada para que houvesse adensamento do material dentro das fôrmas.

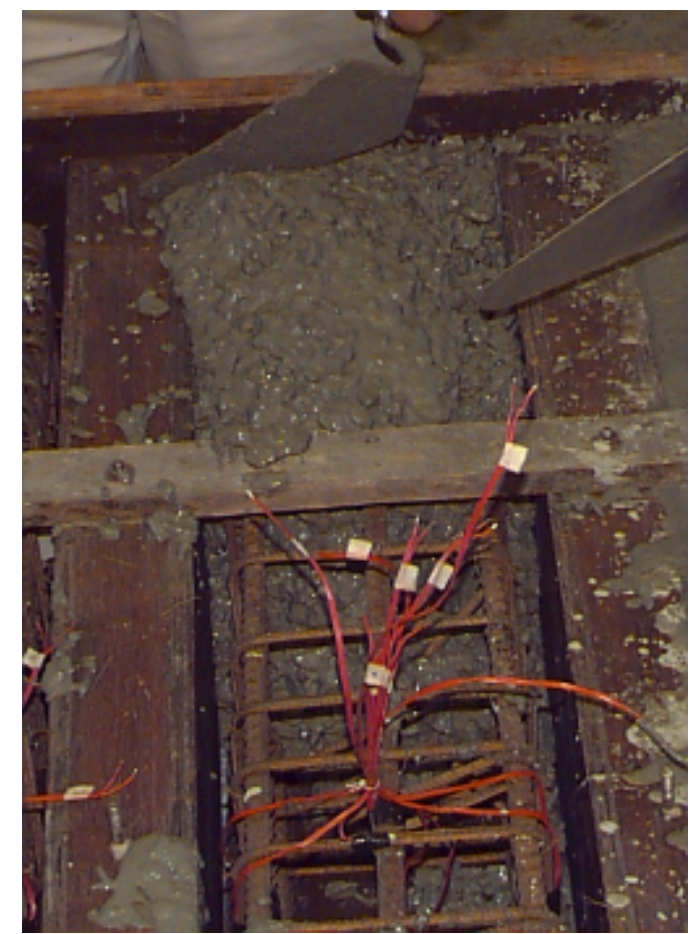

FIGURA 3.14 - Moldagem do Pilar Piloto 2

O concreto feito para o piloto 3 tinha o dobro da quantidade de fibras de aço, comparada com o concreto feito para o pilar 2, e por isso este ficou um pouco mais seco, mas não mais seco do que a mistura de concreto contendo fibras de polipropileno, como pode ser visto na figura 3.15.

A trabalhabilidade dos concretos com adição de fibras de aço foi muito boa, ficando a mistura bastante fluída. A mistura com fibras de polipropileno ficou um pouco mais seca que as misturas contendo fibras de aço, mas mesmo assim sua moldagem foi realizada. 


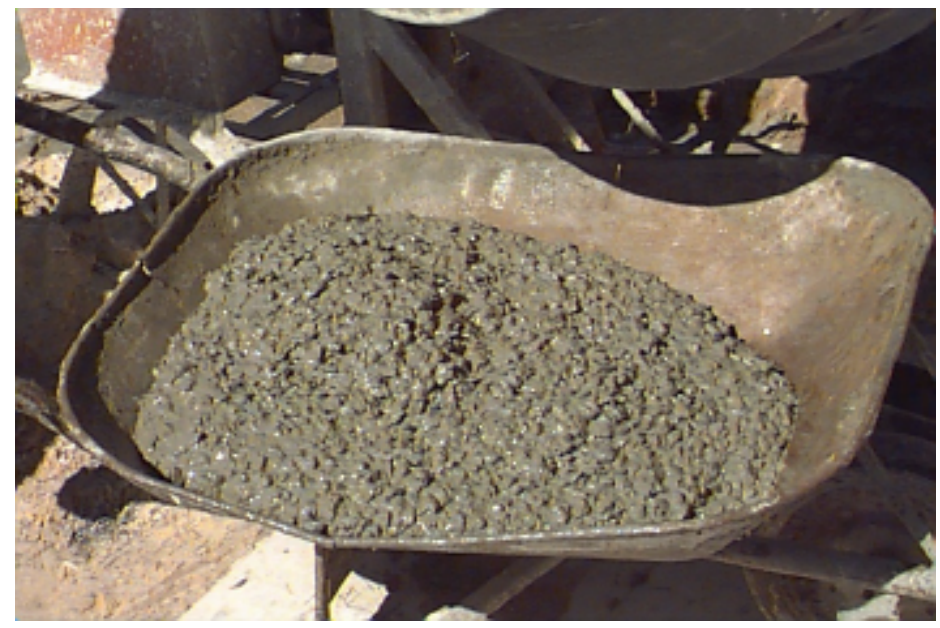

FIGURA 3.15 - Concreto para Moldagem do Pilar 3

Na figura 3.16 é mostrada a configuração final dos três pilares na fôrma já em processo de início de pega do concreto.

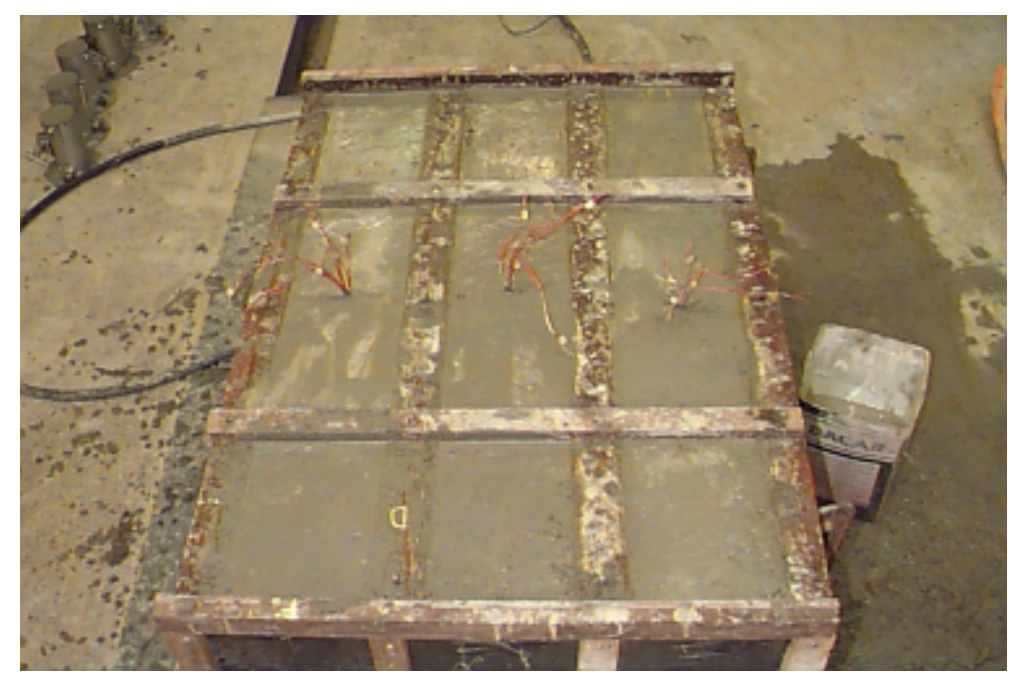

FIGURA 3.16 - Configuração Final da Fôrma

A cura foi feita por sete dias, com o uso de espumas embebidas em água colocadas sobre os pilares, e todo o conjunto foi coberto com lona plástica.

\subsubsection{4 - Instrumentação}

A aplicação de forças foi efetuada por macaco hidráulico com capacidade nominal de $5000 \mathrm{kN}$, acionado por bomba hidráulica de ação manual ou elétrica, de mesma capacidade. 
Os pilares foram instrumentados nas barras das armaduras com strain gage KFG 5 para as barras longitudinais e nos quatros ramos de um estribo, posicionado próximo à metade da altura do pilar. Externamente, foram colados strain gages do tipo KFG 10 nas quatro faces, na mesma posição das barras instrumentadas, para medir a deformação longitudinal do concreto, e dois transdutores de deslocamento em duas faces do pilar, para medirem os deslocamentos, como pode ser visto na figura 3.17 .

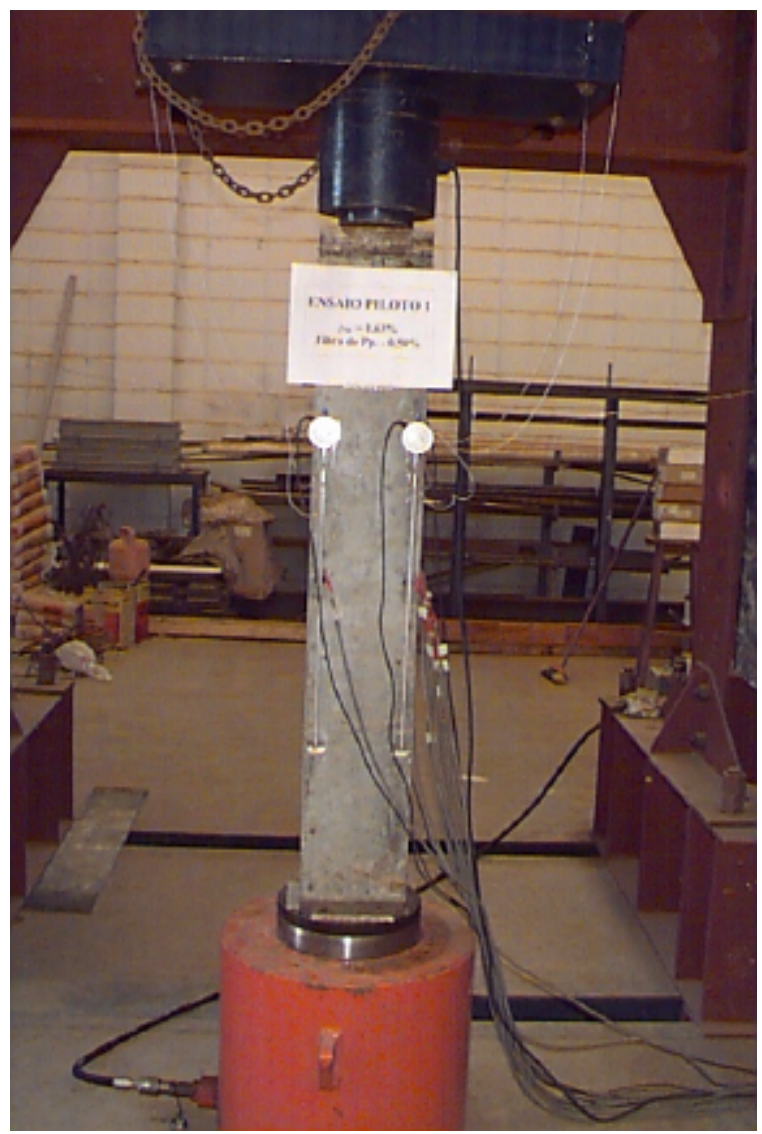

FIGURA 3.17 - Instrumentação dos Pilares Pilotos

\subsubsection{5 - Descrição dos Ensaios Pilotos}

Foram ensaiados dois modelos de pilares com 14 dias: o pilar contendo $0,50 \%$ de taxa de fibras de polipropileno (Piloto 1 ) e o pilar com o concreto contendo $0,50 \%$ de taxa de fibra metálica (Piloto 2); o pilar, com o concreto contendo 1,00\% de taxa de fibra metálica (Piloto 3), foi ensaiado com 15 dias de idade. 
A taxa geométrica de armadura longitudinal $\rho_{\ell}$ foi a mesma para os três modelos $(2,41 \%$ com $8 \phi 12,5 \mathrm{~mm}$ considerando-se a seção transversal total), entretanto o mesmo não ocorreu com a taxa volumétrica de armadura transversal $\rho_{\mathrm{w}}$, que para os modelos 1 e 2 foi de 1,63\% ( $\phi 6,3 \mathrm{c} / 5 \mathrm{~cm}$, considerando-se a área da seção do núcleo, delimitada pelos estribos) e para o modelo 3 foi de $0,82 \%(\phi 6,3 \mathrm{c} / 10 \mathrm{~cm})$. A resistência de escoamento das barras de $12,5 \mathrm{~mm}$ e $6,3 \mathrm{~mm}$ foram de $555,60 \mathrm{MPa}$ e $580,20 \mathrm{MPa}$, respectivamente.

\section{Piloto 1}

O modelo de pilar piloto 1 , com o concreto contendo taxa volumétrica na proporção de 0,50\% de fibra de polipropileno, foi ensaiado com 14 dias de idade, com resistência média à compressão do concreto aos 7 dias de $49,27 \mathrm{MPa}$ e a resistência média à compressão aos 14 dias de 75,46MPa. A área do núcleo central foi medida em $236,24 \mathrm{~cm}^{2}(15,37 \mathrm{~cm} \times 15,37 \mathrm{~cm})$.

Nos ensaios foram aplicados incrementos de força de 50kN. Primeiro aplicaram-se três incrementos (num total de $150 \mathrm{kN}$ ), descarregando o macaco em seguida, antes do início do ensaio propriamente dito, para que pudesse ser feito o escorvamento do pilar. Pôde-se observar, pela instrumentação feita, que a ação não ficou exatamente centrada, visto que o pórtico tinha algumas deformações adquiridas de outros ensaios, mas as excentricidades surgidas não influenciaram de maneira significativa os resultados.

\section{Piloto 2}

O modelo piloto 2 , contendo taxa volumétrica de $0,50 \%$ de fibra metálica, foi ensaiado com 14 dias de idade, com a resistência média à compressão do concreto aos 7 dias de 51,72MPa e a resistência média à compressão aos 14 dias de $71,07 \mathrm{MPa}$. A área do núcleo central foi medida em $251,86 \mathrm{~cm}^{2}(15,87 \mathrm{~cm} \times 15,87 \mathrm{~cm})$.

O escorvamento e os incrementos de força aplicado tanto neste modelo, como no modelo piloto 3 , foram feitos da mesma maneira que no modelo piloto 1 , com escorvamento até $150 \mathrm{kN}$ e incrementos de $50 \mathrm{kN}$ de força. As excentricidades surgidas também foram desprezadas. 


\section{Piloto 3}

O piloto 3, com 1,00\% de taxa de fibra metálica, foi ensaiado com 15 dias de idade, com a resistência média à compressão aos 7 dias de 48,81MPa e aos 14 dias de 68,06MPa. A área do núcleo central foi medida em $245,55 \mathrm{~cm}^{2}(15,67 \mathrm{~cm} \mathrm{x}$ $15,67 \mathrm{~cm})$.

Pôde-se observar pela instrumentação, que para este pilar a célula de carga ficou mais centrada que nos outros ensaios, depois de se ter mexido na posição do macaco hidráulico e colocado chapas de pequena espessura na base do pilar, em forma de calço, para diminuir a excentricidade.

\subsection{3 - ENSAIOS DAS SÉRIES DE PILARES}

A descrição e os resultados de uma parte destes ensaios foram publicados nos anais e aprovados para apresentação em plenário em dois congressos. Um deles, GUIMARÃES, A.E.G.; GIONGO, J.S. \& TAKEYA, T.(1998), foi apresentado no 40. ${ }^{0}$ CONGRESSO BRASILEIRO DO CONCRETO, em agosto de 1998 no Rio de Janeiro, e o outro artigo, GUIMARÃES, A.E.G.; GIONGO, J.S. \& TAKEYA, T.(1999), será publicado e apresentado em junho de 1999, na cidade de Gramado, no II INTERNATIONAL CONFERENCE ON HIGH-PERFORMANCE CONCRETE, AND PERFORMANCE AND QUALITY OF CONCRETE STRUCTURES. Estes resultados também foram descritos no relatório FAPESP (GIONGO(1998)), no processo número 97/00932-6, aprovado em 1998.

\subsubsection{1 - Fôrmas}

O projeto das fôrmas utilizadas para as moldagens dos modelos principais pode ser visto na figura 3.18 .

Elas foram feitas da mesma maneira que aquelas usadas para moldagem dos pilares pilotos, na carpintaria da Escola de Engenharia de São Carlos, com chapas de madeira compensada plastificada de $15 \mathrm{~mm}$ de espessura e caibros, apenas sendo modificadas de modo a serem produzidos dois pilares a cada concretagem.

Eram preenchidas na posição horizontal em no mínimo 4 camadas, e o adensamento foi feito com o auxílio de mesa vibratória, para que o concreto com 
fibras pudesse passar por entre a armadura de fretagem, que era posicionada nas extremidades dos modelos.

O cobrimento de armadura usado foi de $1,75 \mathrm{~cm}$, e o posicionamento da armadura dentro das fôrmas era conseguido com o uso de espaçadores de argamassa, iguais aos usados nos modelos pilotos, mostrado na figura 3.10.
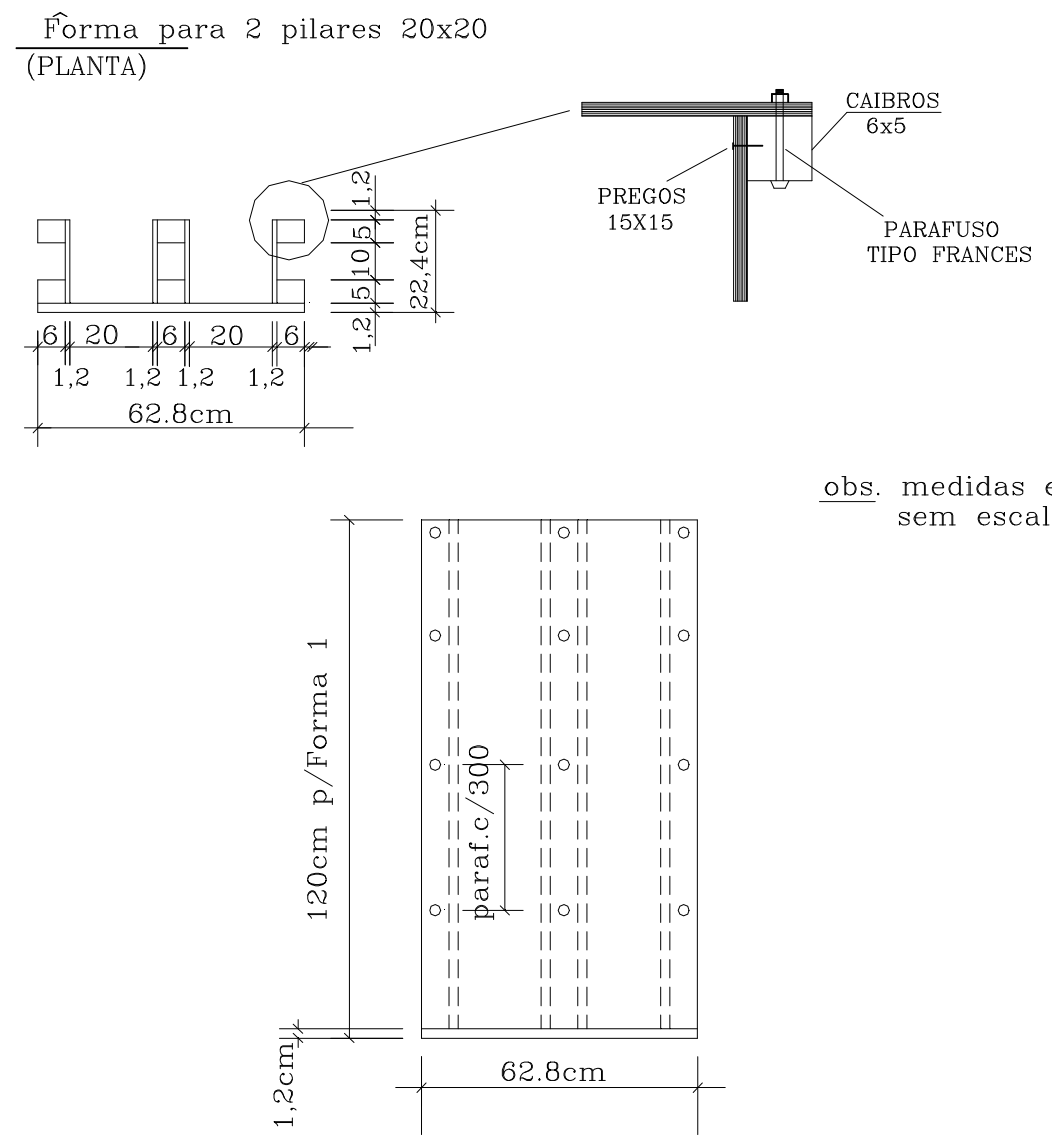

obs. medidas em centimetros sem escala

\section{VISTA FRONTAL}

FIGURA 3.18 - Fôrma Utilizada para Moldagem das Séries de Pilares

\subsubsection{2 - Instrumentação}

Para os ensaios das séries de modelos de pilares, a instrumentação das barras longitudinais, do estribo e do concreto foram a mesma, não sendo modificada nem a posição dos strain gages. Mas os transdutores de deslocamento foram colocados um em cada face de concreto, nos quatro lados do pilar, e os strain gages colados no concreto tinham condição de medir as deformações em duas direções, como pode ser visto na figura 3.19 . 
A chapa de aço colocada na extremidade inferior sofreu deformações nos ensaios anteriores, portanto, foi necessário o uso de pequenas chapas de aço (bastante finas) para que o pilar ficasse no prumo para alinhamento com a célula de carga. Uma proteção de chapa de madeira compensada foi colocada ao redor do pórtico, para que fosse evitado algum acidente durante as execuções dos ensaios.

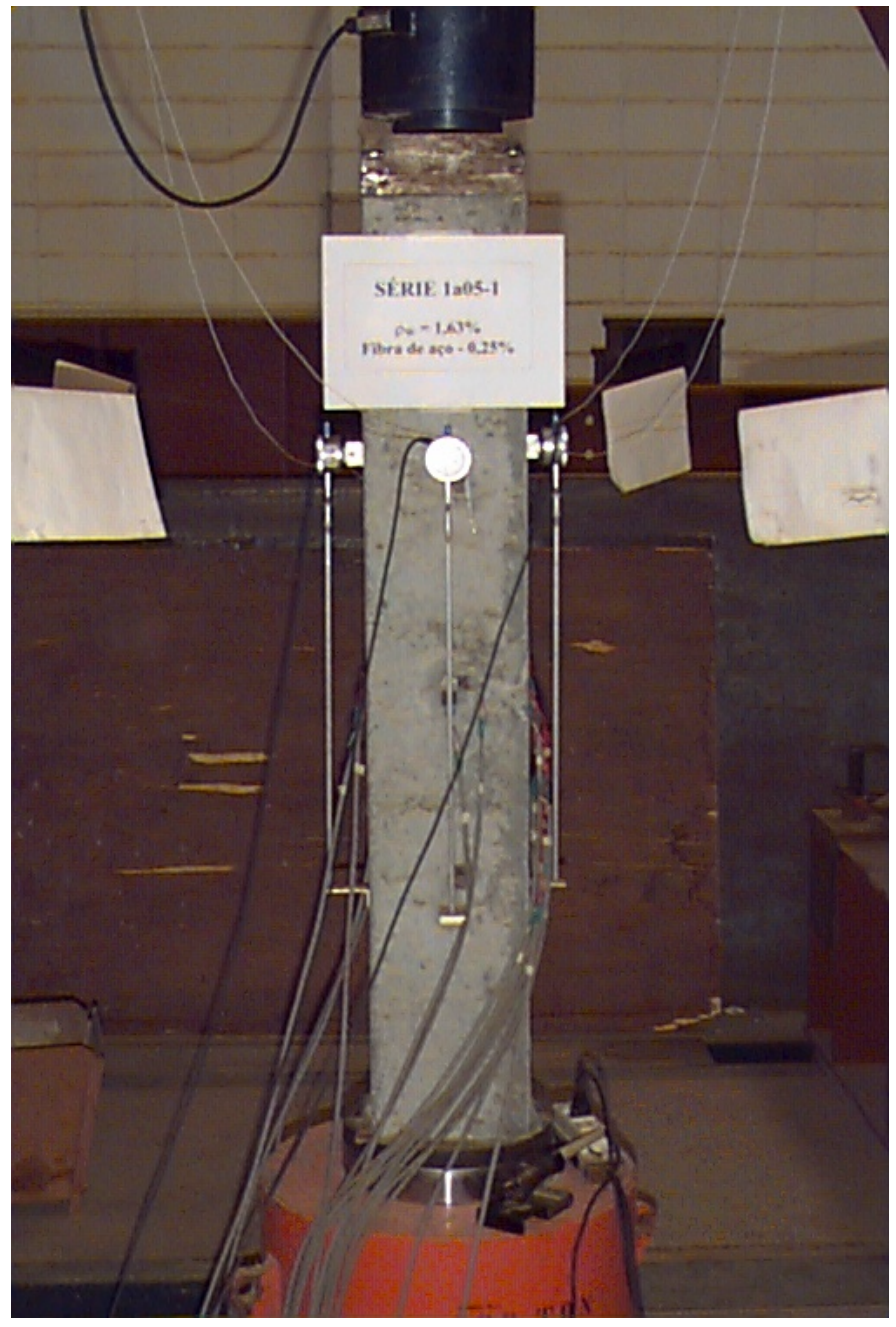

FIGURA 3.19 - Instrumentação das Séries de Pilares

\subsubsection{4 - Descrição dos Ensaios}

Foram moldadas e ensaiadas 13 séries de pilares, com dois modelos por série. Entretanto, uma delas foi refeita totalizando, portanto, 28 modelos. As séries são classificadas pela taxa de fibras adicionadas, representada pelo primeiro número que aparece na denominação dos modelos, onde $\mathbf{1}$ significa adição de $0,25 \%$ de fibras, 2 representa $0,50 \%, 3$ equivale a $1,00 \%$ e $\mathbf{4}$ corresponde a $0,75 \%$, pelo tipo de fibra, 
aço ou polipropileno, representado pela letra a ou p, respectivamente, e pela taxa de armadura transversal, onde o espaçamento entre estribos, em centímetros, é representado pelos dois últimos números da denominação dos pilares, visto que estes eram os 3 parâmetros variáveis nos ensaios.

Escolheu-se trabalhar com espaçamento de estribos a cada $15 \mathrm{~cm}$, por ser uma medida recomendada pela NBR 6118/78, para estes pilares em particular, onde a seção transversal de $20 \mathrm{~cm}$ x $20 \mathrm{~cm}$ e a armadura longitudinal, $8 \phi 12,5 \mathrm{~mm}$, foram os mesmos para todos os modelos.

As fotografias dos pilares rompidos podem ser vistas no Apêndice B.

\section{Série P1a15}

Nesta série o concreto continha adição de $0,25 \%$ de taxa de fibras e a taxa de armadura transversal era de $0,55 \%(\phi 6,3 \mathrm{c} / 15 \mathrm{~cm})$.

Foram moldados 2 pilares em duas etapas de mistura, e 5 corpos-de-prova para cada pilar, num total de 10 .

Nas extremidades dos pilares foram posicionadas armaduras de fretagem ao longo de $18,5 \mathrm{~cm}$ para melhor distribuição das tensões. Isto foi feito para todos os modelos. A preocupação era que o concreto com fibras não tivesse passagem por entre os estribos naquela região.

A primeira mistura ficou bastante plástica, e a segunda teve pequeno aumento no abatimento medido pelo tronco de cone (Slump Test), portanto, não ocorreram maiores dificuldades na concretagem dos dois modelos, nem mesmo na região de maior concentração de armadura, que eram as extremidades.

Os ensaios dos pilares foram feitos um com 15 dias e outro com 16 dias de idade, os ensaios à compressão com controle de força dos corpos-de-prova de concreto foram feitos com 15 dias.

\section{Série P1a10}

Nesta série o concreto continha adição de $0,25 \%$ de taxa de fibras e a taxa de armadura transversal era de $0,82 \%(\phi 6,3 \mathrm{c} / 10 \mathrm{~cm})$.

A mistura de concreto foi feita em uma única etapa e ficou bastante plástica, o que facilitou a moldagem dos dois pilares, principalmente nas extremidades. As 
fibras tiveram passagem por entre as armaduras, e o adensamento foi feito em duas camadas com a mesa vibratória.

A quantidade de corpos-de-prova moldados com a mistura desta série de modelos foi de 13, o que foi assumido para todas as outras séries. As misturas para as concretagens dos pilares da série P1a15 ficaram mais plásticas que as feitas para a série P1a10. Isto se deve ao fato da mistura ter sido feita em apenas uma etapa, enquanto que a outra foi feita em duas betonadas.

No ensaio do pilar P1a10-2 teve-se alguma dificuldade para centrar a força no pilar, o qual teve que ser reposicionado várias vezes, pois pela leitura das deformações das barras e do concreto o pilar estava sofrendo flexão oblíqua composta. Quando o pilar foi posicionado de tal maneira que as leituras das deformações ficassem compatíveis com a aplicação de força centrada, visualmente a célula de carga estava fora do seu ponto de aplicação, ou seja, não estava devidamente encaixada com a chapa de aço que ficava sobre a extremidade superior do pilar. O ensaio foi realizado desta maneira e a força de ruptura foi um pouco menor que a prevista em cálculo.

O ensaio do pilar P1a10-1 foi realizado sem dificuldade para centralização da força.

Os ensaios dos pilares foram feitos um com 15 dias e outro com 16 dias de idade, os ensaios à compressão com controle de força dos corpos-de-prova de concreto foram feitos 3 com 7 dias e 3 com 15 dias e os ensaios com compressão diametral em 3 corpos-de-prova e à compressão com deformação controlada em 4 espécimes, foram realizados aos 15 dias, para todas as séries.

\section{Série P1a05}

Nesta série o concreto continha adição de $0,25 \%$ de taxa de fibras e a taxa de armadura transversal era de $1,63 \%(\phi 6,3 \mathrm{c} / 05 \mathrm{~cm})$.

A mistura teve uma plasticidade muito boa e isto facilitou bastante a moldagem dos pilares, visto que o espaçamento entre os estribos era pequeno em relação às outras séries $(\phi 6,3 \mathrm{c} / 05 \mathrm{~cm})$. 
O adensamento dos corpos-de-prova foi feito na mesa vibratória para que não houvesse orientação das fibras, o que pode acontecer quando o vibrador de agulha é usado.

Os ensaios dos pilares foram feitos seguindo-se o mesmo procedimento das demais séries.

\section{Série P2a15}

Nesta série o concreto continha adição de $0,50 \%$ de taxa de fibras e a taxa de armadura transversal era de $0,55 \%(\phi 6,3 \mathrm{c} / 15 \mathrm{~cm})$.

A preocupação era que o concreto com fibras não tivesse passagem por entre os estribos nas regiões da base e do topo, visto que a quantidade de fibras foi o dobro daquelas usadas nas séries P1a15, P1a10 e P1a05.

A mistura teve um abatimento menor, devido ao aumento da quantidade de fibras, mas não houve dificuldade no adensamento do concreto, nem mesmo nas regiões das armaduras de fretagem.

Durante o ensaio do pilar 2, não foi possível, após várias tentativas, centrar a aplicação da força no pilar. A célula de carga estava um pouco desalinhada e mesmo tirando o pilar do prumo, o resultado do ensaio não foi muito bom. $\mathrm{O}$ fato do pilar ter rompido com uma força mais baixa do que a esperada, foi creditado à presença de pequena flexão no elemento.

Pelos resultados obtidos, a conclusão é que os ensaios dos dois pilares desta série não ficaram bons, pois a força de ruptura experimental foi menor do que a calculada e pelos gráficos feitos com os dados lidos pelo sistema de aquisição dos mesmos, ficou evidenciado que a força aplicada caracterizou uma flexo-compressão, o que não era objetivo da pesquisa. Portanto, esta série foi refeita.

\section{Série P2a15-r}

Foi utilizado pela primeira vez, durante a etapa de mistura, misturador de eixo vertical com maior capacidade do que a betoneira usada nas concretagens anteriores, sendo o concreto feito em apenas uma etapa.

O resultado do Slump Test teve um valor alto, conferindo ótima trabalhabilidade ao concreto, apesar de ter havido alguns problemas elétricos com o 
maquinário, visto que estava sendo utilizado pela primeira vez. Ele foi usado apenas nesta série, e para a concretagem das outras séries de pilares voltou-se a usar betoneira comum.

Durante o ensaio do pilar 2, foi possível após várias tentativas, centrar a aplicação da força no pilar. O pilar teve que ser colocado fora de prumo para que as leituras das deformações ficassem uniformes.

\section{Série P2a10}

Nesta série o concreto continha adição de $0,50 \%$ de taxa de fibras e a taxa de armadura transversal era de $0,82 \%(\phi 6,3 \mathrm{c} / 10 \mathrm{~cm})$.

A chapa metálica que sustentava a célula de carga no pórtico de reação foi invertida, o que facilitou a centralização da carga para execução dos ensaios dos pilares.

\section{Série P2a05}

Nesta série o concreto continha adição de $0,50 \%$ de taxa de fibras e a taxa de armadura transversal era de $1,63 \%(\phi 6,3 \mathrm{c} / 05 \mathrm{~cm})$.

A boa plasticidade da mistura facilitou bastante a moldagem dos pilares, visto que o espaçamento entre os estribos era pequeno em relação às outras séries $(\phi 6,3$ $\mathrm{c} / 05 \mathrm{~cm})$, com o concreto contendo maior quantidade de fibras.

Os ensaios dos pilares foram feitos, cada um, com mais de 20 etapas de aplicação de força com $50 \mathrm{kN}$ cada, sendo que entre uma etapa e outra eram esperados 2 minutos para acomodação das deformações, então eram feitos os registros das leituras. Não houve problemas para centralização da força nesta série.

\section{Série P3a15}

Nesta série o concreto continha adição de $1,00 \%$ de taxa de fibras e a taxa de armadura transversal era de $0,55 \%(\phi 6,3 \mathrm{c} / 15 \mathrm{~cm})$.

Devido ao fato da mistura conter o dobro da quantidade de fibras em relação às séries $\mathrm{P} 2 \mathrm{a} 15, \mathrm{P} 2 \mathrm{a} 10$ e $\mathrm{P} 2 \mathrm{a} 05$, ficou a preocupação da moldagem das extremidades dos pilares, visto que a concentração de armadura nesta região era muito grande, mas, devido a boa trabalhabilidade do concreto, a concretagem foi feita facilmente. 
A mistura teve um abatimento menor que das outras séries, o que era esperado devido à quantidade de fibras adicionadas à mistura.

Os ensaios foram realizados sem incidentes tanto para centralização da carga quanto para sua aplicação durante o ensaio até a ruptura do elemento. Em ambos pilares, as rupturas foram bruscas, mas com pequena intensidade, devido a baixa taxa de estribos para ductilização do elemento, o que aconteceu em todas as séries de pilares cujo espaçamento entre estribos era de $15 \mathrm{~cm}$.

\section{Série P3a10}

Nesta série o concreto continha adição de 1,00\% de taxa de fibras e a taxa de armadura transversal era de $0,82 \%(\phi 6,3 \mathrm{c} / 10 \mathrm{~cm})$.

O cimento estava um pouco empedrado e portanto não propício para uso no concreto. Na falta de material de melhor qualidade, fez-se o peneiramento de parte do cimento para que o mesmo pudesse ser usado.

Nos ensaios dos dois pilares desta série, foi seguido o mesmo procedimento das demais séries, ou seja, as etapas de aplicação de força foram feitas com tempo de espera de 2 minutos entre uma e outra, para que houvesse acomodação das deformações, antes das leituras serem registradas pelo sistema de aquisição de dados.

\section{Série P3a05}

Nesta série o concreto continha adição de $1,00 \%$ de taxa de fibras e a taxa de armadura transversal era de $1,63 \%(\phi 6,3 \mathrm{c} / 05 \mathrm{~cm})$.

A mistura teve boa plasticidade, mesmo com o aumento da quantidade de fibras. Quando estava sendo feito o Slump Test, o concreto teve um desmoronamento, devido à grande quantia de fibras na massa, mas isso não impediu que o mesmo fosse utilizado para moldagem dos pilares e esta foi feita em etapas com auxílio da mesa vibratória. A moldagem dos corpos-de-prova foi feita em outra mesa vibratória de menor tamanho.

Os ensaios, quanto as etapas de aplicação de força, foram feitos da seguinte maneira: até a etapa de $1.200 \mathrm{kN}$, era esperado 1 minuto para que o registro da leitura das deformações fosse feito. Após essa etapa, até $2.150 \mathrm{kN}$, eram esperados 2 minutos para se registrar as leituras e, após essa etapa até a ruína a leitura era feita 
automaticamente, com a ação sendo aplicada constantemente. Os resultados de todas as séries podem ser vistos na tabela 4.13 , no capítulo 4 .

\section{Série P4a15}

Nesta série o concreto tinha adição de $0,75 \%$ de taxa de fibras e a taxa de armadura transversal era de $0,55 \%(\phi 6,3 \mathrm{c} / 15 \mathrm{~cm})$.

A mistura teve plasticidade bastante boa. Quando estava sendo feito o Slump Test, o concreto teve um desmoronamento, igual ao ocorrido com o concreto contendo $80 \mathrm{~kg} / \mathrm{m}^{3}$ de fibras, mostrando assim, que talvez o Slump Test não seja adequado para se medir a trabalhabilidade de concreto com fibras contento quantidades acima de $40 \mathrm{~kg} / \mathrm{m}^{3}$. Abaixo desta quantidade, o Slump Test se mostrou confiável para que se tivesse uma idéia da trabalhabilidade do concreto, mas acima deste valor, havia desmoronamento do concreto moldado pelo cone, fazendo com que o teste ficasse inválido. Com a boa fluidez da mistura, os pilares puderam ser moldados em algumas camadas e adensados na mesa vibratória.

\section{Série P4a10}

Nesta série o concreto continha adição de $0,75 \%$ de taxa de fibras e a taxa de armadura transversal era de $0,82 \%(\phi 6,3 \mathrm{c} / 10 \mathrm{~cm})$.

Os ensaios com os modelos foram feitos normalmente e não houve problemas para execução dos ensaios dos mesmos nesta série.

\section{Série P4a05}

Nesta série o concreto continha adição de $0,75 \%$ de taxa de fibras e a taxa de armadura transversal era de $1,63 \%(\phi 6,3 \mathrm{c} / 05 \mathrm{~cm})$.

Os ensaios transcorreram bem, com a centralização da força sendo feita mais facilmente. A ruptura não foi brusca, como era característica dos ensaios dos pilares que continham taxa de armadura transversal de 1,63\%.

\section{Série P3p10}

Nesta série o concreto continha adição de $0,50 \%$ de taxa de fibras de polipropileno e a taxa de armadura transversal era de $0,82 \%(\phi 6,3 \mathrm{c} / 10 \mathrm{~cm})$. 
A mistura foi feita em uma única etapa, que ficou com menos trabalhabilidade do que os concretos das outras séries, por causa da fibra de polipropileno, o que prejudicou um pouco a moldagem dos pilares, mas com o auxílio da mesa vibratória, foi possível adensar o concreto nas fôrmas. A moldagem dos corpos-de-prova foi feita na mesa vibratória menor.

Os ensaios dos modelos desta série foram feitos na máquina de ensaios INSTRON, com aplicação de força mas com controle de deslocamento no pilar. Como a máquina estava em fase de testes de instalação, não foi possível extrair dados interessantes no ensaio do primeiro modelo. Com alguma dificuldade, conseguiu-se obter apenas os dados do ensaio do modelo 2, o qual se apresenta no capítulo 4.

Para esta série foram dispensados os transdutores de deslocamento e a leitura dos strain gages foi feita pelo sistema de aquisição de dados, em paralelo com a leitura das deformações do pilar, feita pela própria máquina INSTRON. 


\section{RESULTADOS DOS ENSAIOS}

\section{1 - CONSIDERAÇÕES INICIAIS}

Neste capítulo são apresentados os resultados obtidos na fase inicial da pesquisa, de avaliação da resistência do concreto com adição de fibras, através dos ensaios de corpos-de-prova de $100 \mathrm{~mm}$ x 200mm, as características mecânicas e geométricas dos modelos de pilares e os valores observados para a força última experimental. Em seguida são mostrados os diagramas elaborados a partir dos resultados obtidos através do sistema de aquisição de dados.

\section{2 - CARACTERÎSTICAS MECÂNICAS DO CONCRETO COM}

\section{FIBRAS}

\subsection{1 - CONCRETO COM FIBRAS METÁLICAS}

Os corpos-de-prova das séries A, B, C e D foram ensaiados aos 3, 7, 15 e 28 dias de idade para determinação das resistências médias à compressão e do módulo de elasticidade, e com 15 dias, foram medidas as resistências médias à tração através do ensaio de compressão diametral, como foi descrito no capítulo 4. 
Para a série $\mathrm{A}$, as variações das resistências médias à compressão e dos valores do módulo de elasticidade com a idade são vistas na figura 4.1.

Na figura 4.1a é mostrada a variação da resistência média à compressão do concreto da série A com o tempo; a 4.1b mostra a variação com a idade do módulo de elasticidade médio do concreto com adição de $1 \%$ de fibras e, o gráfico 4.1c mostra o comportamento do concreto aos 3 dias, 7 dias, 15 dias e 28 dias através dos diagramas tensão x deformação.

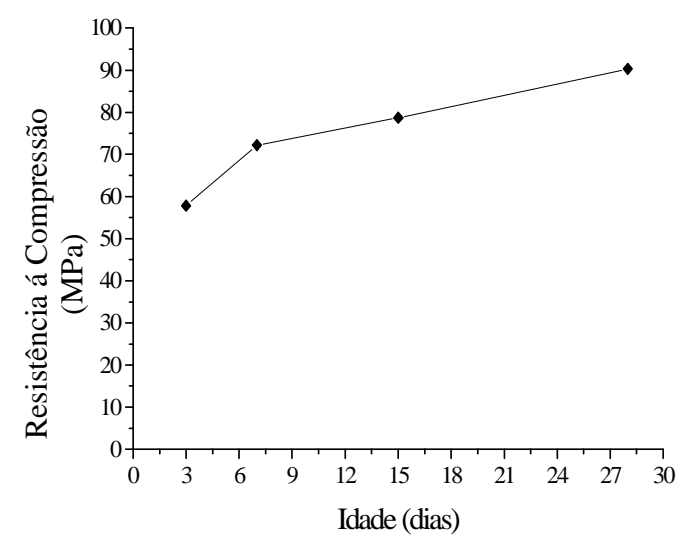

(a)

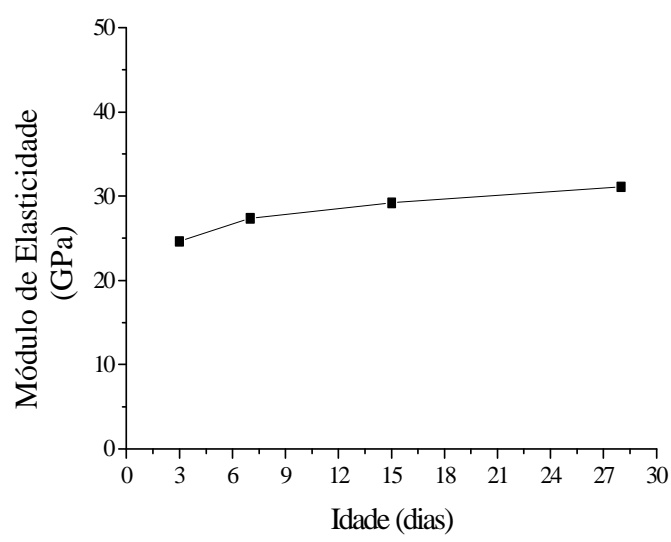

(b)

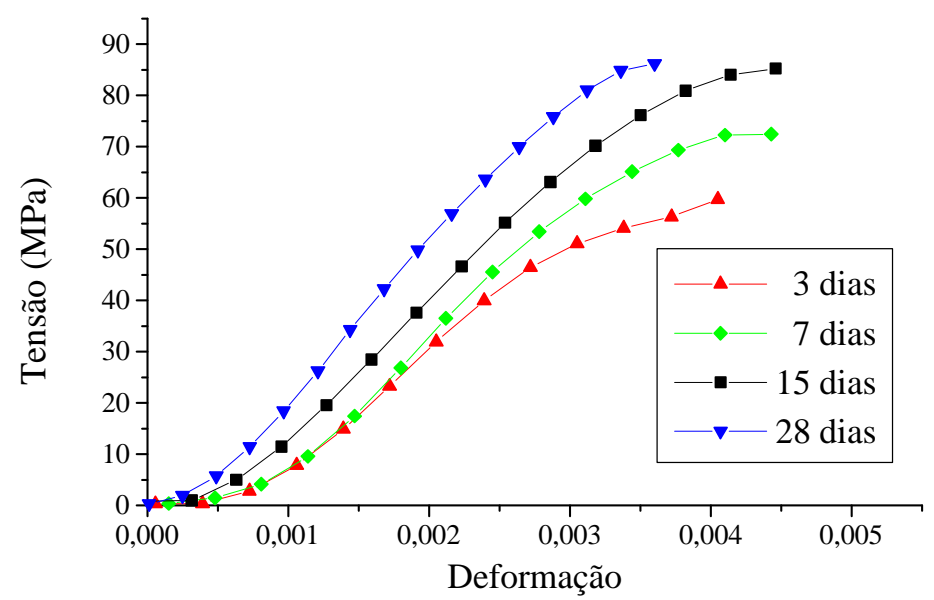

(c)

FIGURA 4.1 - Comportamento do Concreto da Série A

A relação entre a resistência média à tração $(6,91 \mathrm{MPa})$ e a resistência média à compressão $(78,72 \mathrm{MPa})$ para o concreto da série A ficou em 8,78\%, medidas aos 15 dias de idade. 
Para a série $\mathrm{B}$, o crescimento da resistência média à compressão com a idade é mostrado na figura 4.2, junto com o crescimento do módulo de elasticidade.

Note-se que na figura 4.2a a variação da resistência média à compressão com o tempo é mais significativa nas primeiras idades, tornando-se insignificante de 15 dias para 28 dias. O gráfico 4.2b mostra que a variação do módulo de elasticidade com o tempo é relativamente pequena em 4.2c pode-se ver os diagramas tensão $\mathrm{x}$ deformação para o concreto da série B aos 3 dias, 7 dias, 15 dias e 28 dias de idade.

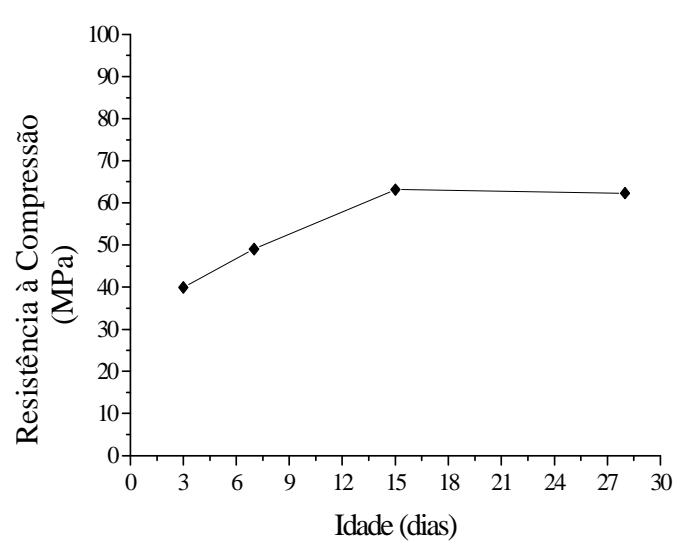

(a)

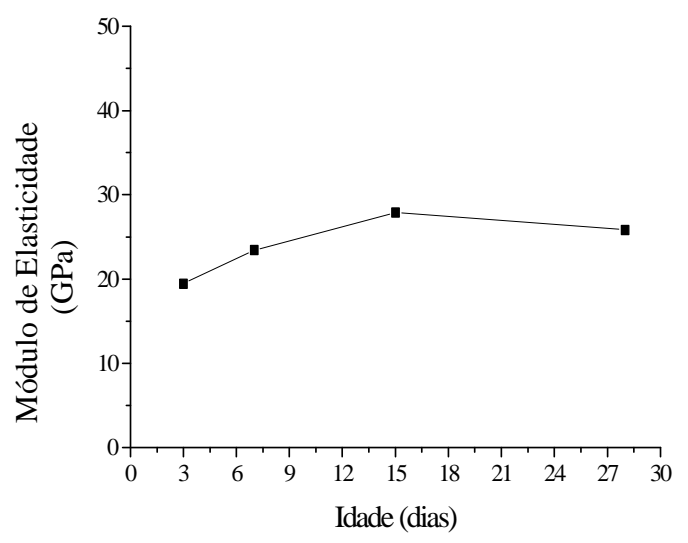

(b)

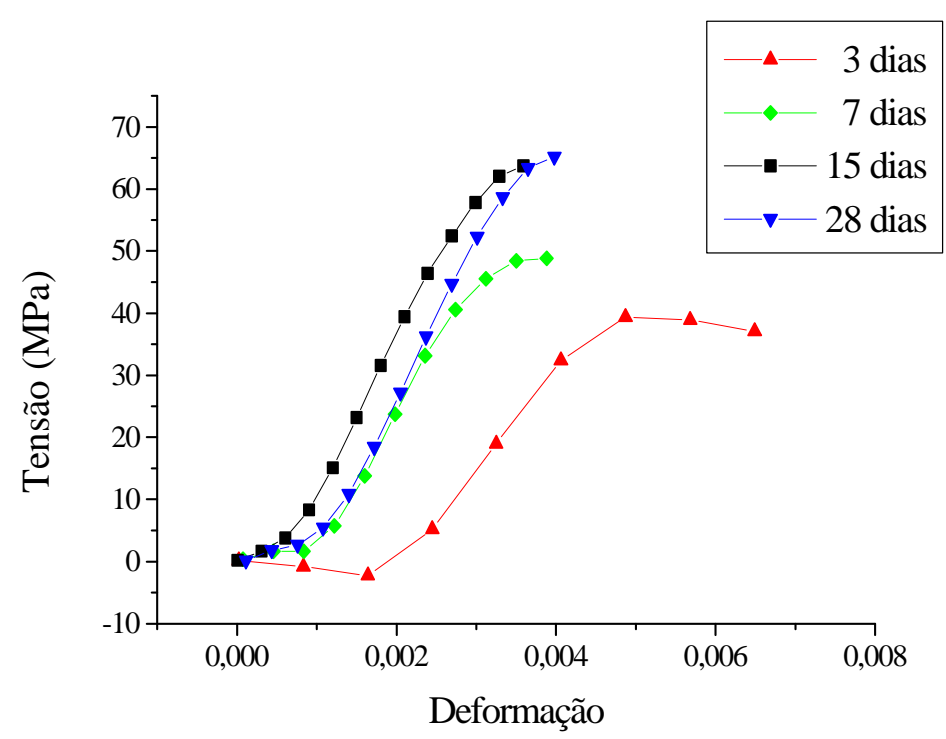

(c)

FIGURA 4.2 - Comportamento do Concreto da Série B 
A relação entre a resistência média à tração $(5,40 \mathrm{MPa})$ e a resistência média à compressão $(63,17 \mathrm{MPa})$ para o concreto da série $\mathrm{B}$ ficou em $8,55 \%$.

Para a série $\mathrm{C}$, o crescimento da resistência média à compressão com a idade é mostrado na figura 4.3 , junto com o crescimento do módulo de elasticidade.

$\mathrm{Na}$ figura 4.3a, pode ser visto o comportamento da resistência média à compressão do concreto, com adição de $0,25 \%$ de taxa volumétrica de fibra metálica, com a idade; na figura 4.3b encontra-se a variação do módulo de elasticidade com a idade; e a figura 4.3c mostra os diagramas tensão x deformação do concreto.

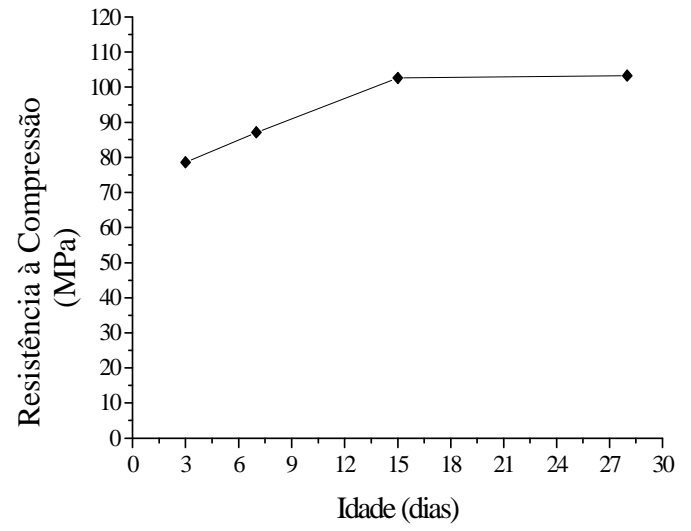

(a)

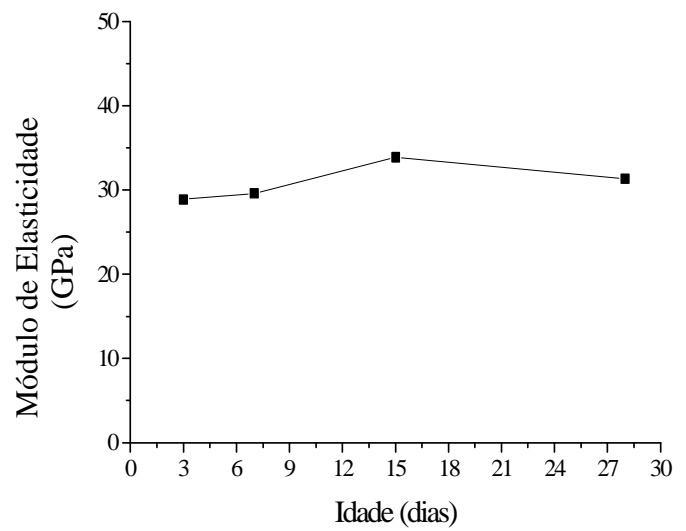

(b)

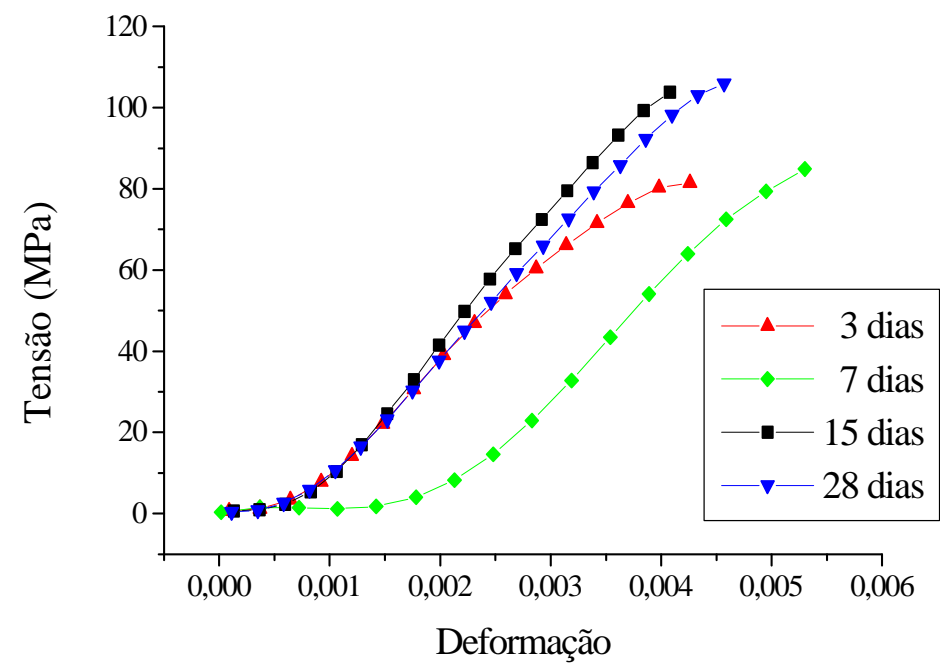

(c)

FIGURA 4.3 - Comportamento do Concreto da Série C 
O módulo de elasticidade do concreto da série $\mathrm{C}$ teve um acréscimo maior de 3 dias para 15 dias, havendo uma estabilização de 15 dias para 28 dias e a relação entre a resistência média à tração $(5,76 \mathrm{MPa})$ e a resistência média à compressão (102,61 MPa) para o concreto da série C ficou em 5,62\%.

Para a série $\mathrm{D}$, as variações da resistência média à compressão e do módulo de elasticidade com a idade são mostradas na figura 4.4. A figura 4.4a apresenta o crescimento da resistência média à compressão do concreto da série D com o tempo; a figura 4.4b mostra a variação do módulo de deformação longitudinal com a idade; e na figura 4.4c encontra-se o comportamento dos diagramas tensão x deformação nas datas anteriormente descritas.

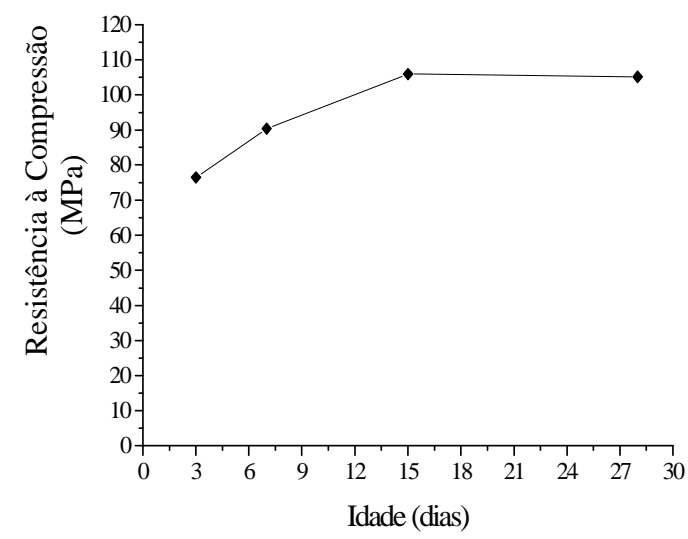

(a)

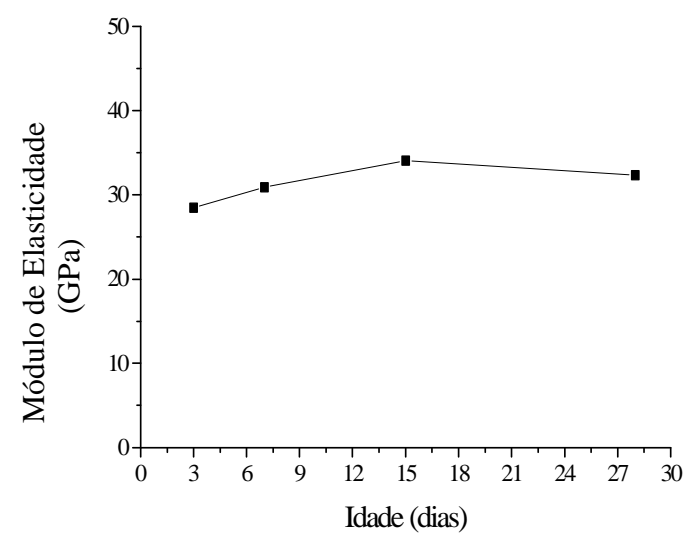

(b)

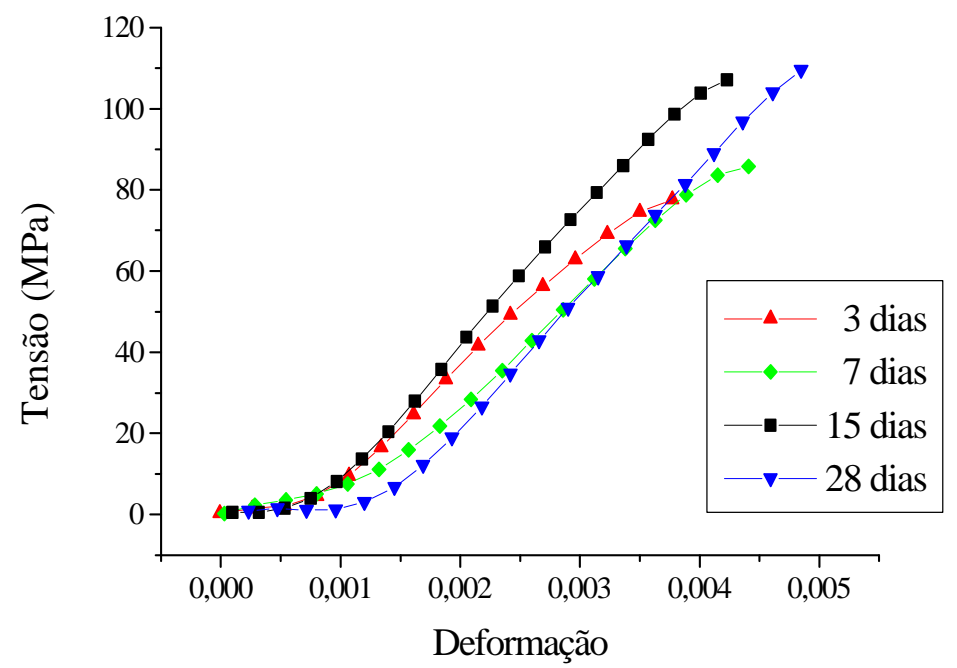

(c)

FIGURA 4.4 - Comportamento do Concreto da Série D 
A relação entre a resistência média à tração $(5,30 \mathrm{MPa})$ e a resistência média à compressão (105,94 MPa) para o concreto da série D ficou em 5,00\%.

\subsection{2 - FIBRAS DE POLIPROPILENO}

Foram feitos 15 corpos-de-prova para as séries de concretagem E, F e G, para determinação das resistências médias à compressão e dos módulos de elasticidade aos 3, 7, 15 e 28 dias de idade, e determinação da resistência média à tração, através do ensaio de compressão diametral, aos 15 dias de idade, tempo em que será feito os ensaios dos pilares. Para a série E, as variações da resistência média à compressão e do módulo de elasticidade com a idade são vistas na figura 4.5.

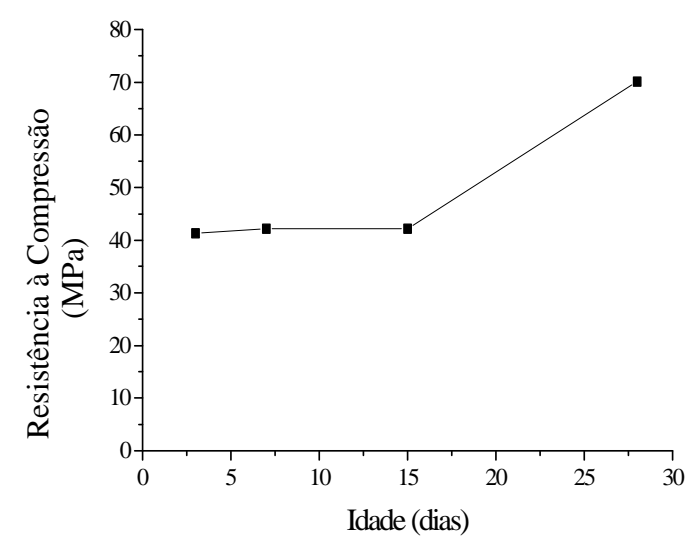

(a)

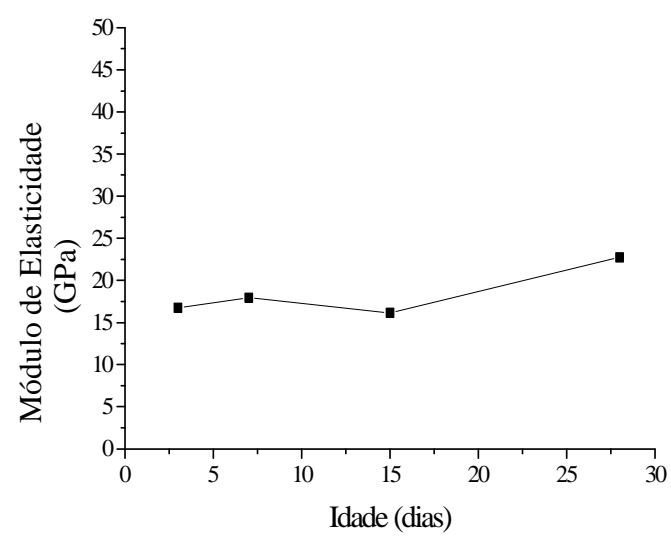

(b)

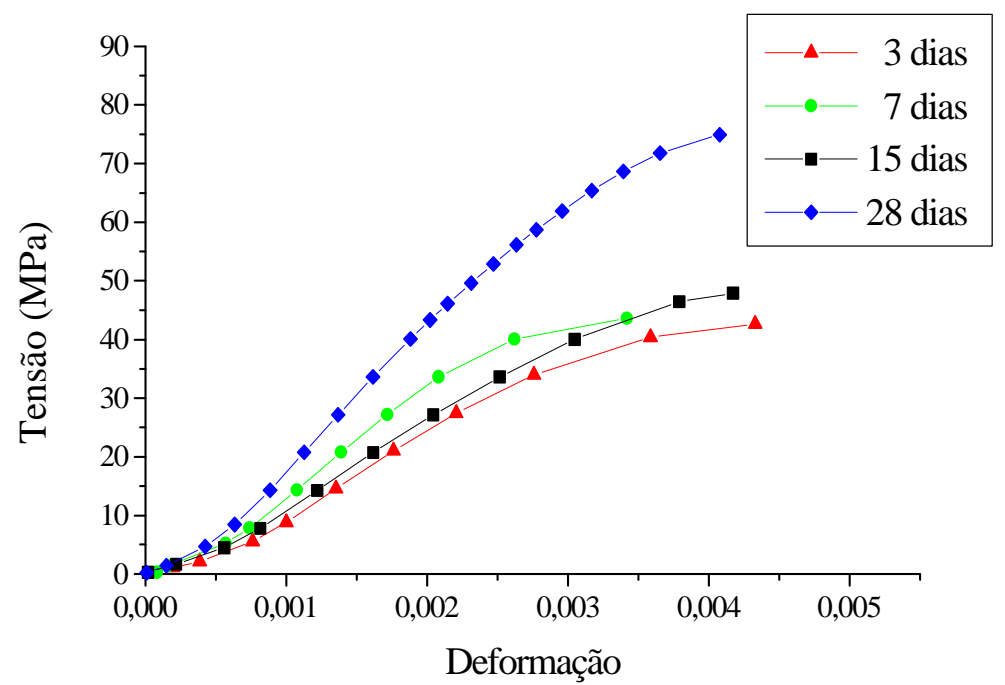

(c)

FIGURA 4.5 - Comportamento do Concreto da Série E 
Na figura 4.5a é mostrada a variação da resistência média à compressão do concreto da série A com o tempo; a 4.5b mostra a variação com a idade do módulo de elasticidade médio do concreto com adição de $1 \%$ de fibras e, o gráfico $\mathbf{4 . 5 c}$ mostra o comportamento do concreto aos 3 dias, 7 dias, 15 dias e 28 dias através dos diagramas tensão $\mathrm{x}$ deformação. A relação entre a resistência média à tração $(5,52$ $\mathrm{MPa})$ e a resistência média à compressão $(42,15 \mathrm{MPa})$ para o concreto da série $\mathrm{E}$ ficou em 13,09\%, medidas aos 15 dias de idade.

Para a série F, o crescimento da resistência média à compressão com a idade é mostrado na figura 4.6, junto com o crescimento do módulo de elasticidade.

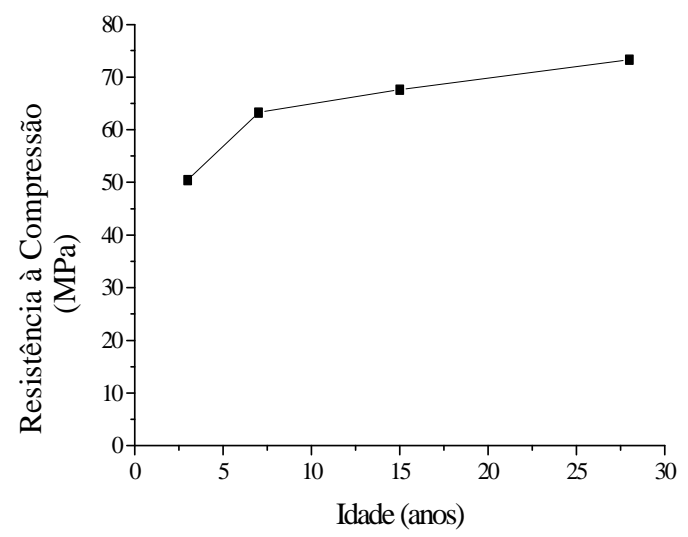

(a)

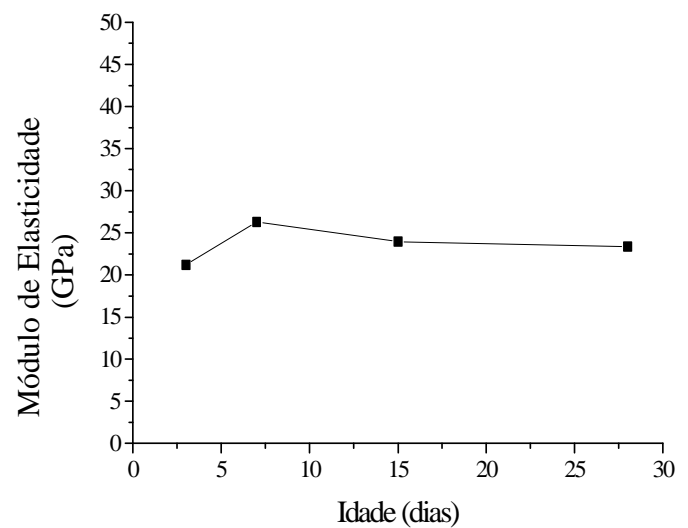

(b)

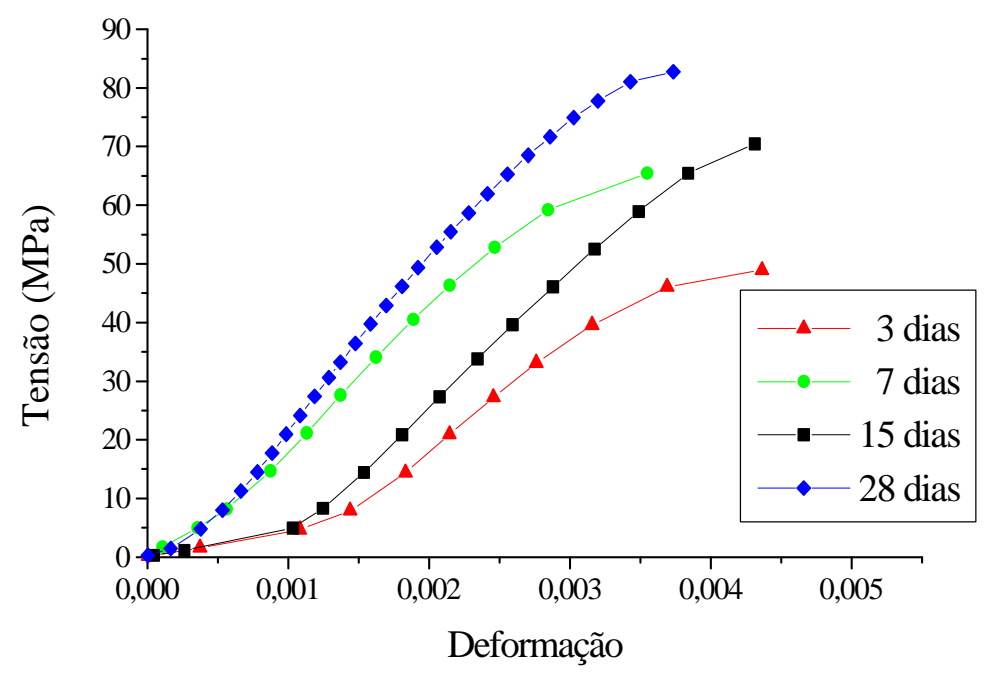

(c)

FIGURA 4.6 - Comportamento do Concreto da Série F 
Note-se que na figura 4.6a a variação da resistência média à compressão com o tempo é mais significativa nas primeiras idades, diminuindo o acréscimo de 15 dias para 28 dias. O gráfico 4.6b mostra que a variação do módulo de elasticidade com o tempo tem um acréscimo de 3 dias para 7 dias, sofrendo um decréscimo até 28 dias. Na figura 4.6c pode-se ver os diagramas tensão x deformação para o concreto da série $\mathrm{F}$ aos 3 dias, 7 dias, 15 dias e 28 dias de idade.

A relação entre a resistência média à tração $(5,20 \mathrm{MPa})$ e a resistência média à compressão $(67,64 \mathrm{MPa})$ para o concreto da série $\mathrm{F}$ ficou em 7,69\%.

Para a série $\mathrm{G}$, o crescimento da resistência média à compressão com a idade é mostrado na figura 4.7 , junto com o crescimento do módulo de elasticidade.

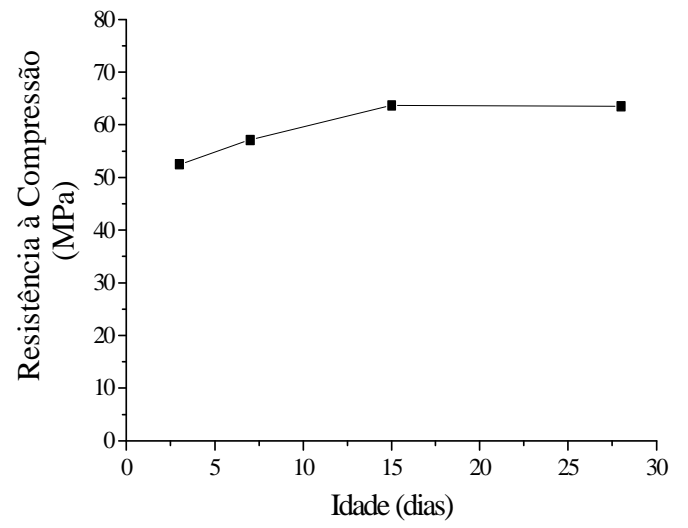

(a)

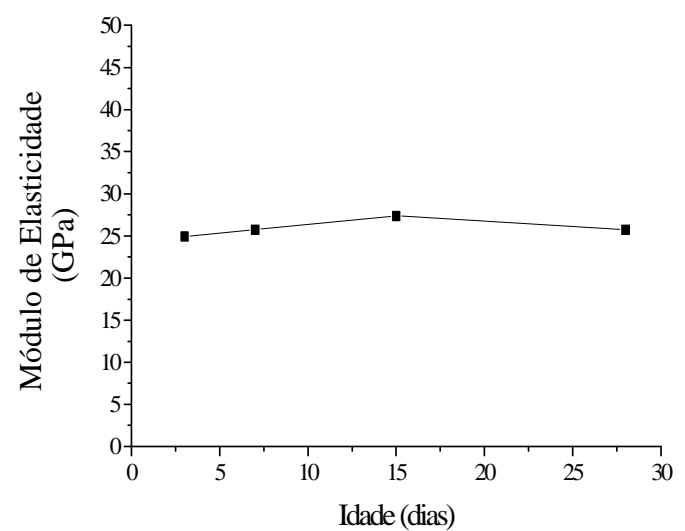

(b)

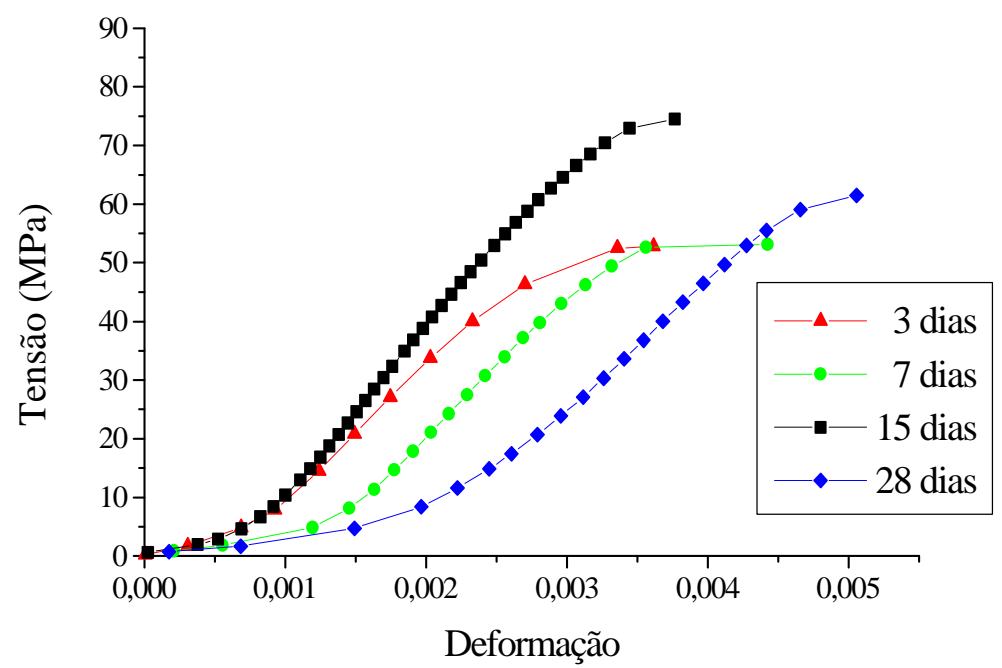

(c)

FIGURA 4.7 - Comportamento do Concreto da Série G 
$\mathrm{Na}$ figura 4.7a, pode ser visto o comportamento da resistência média à compressão do concreto, com adição de 0,25 de taxa volumétrica de fibra polimérica, com a idade; na figura 4.7b encontra-se a variação do módulo de elasticidade com a idade; e a figura 4.7c mostra os diagramas tensão x deformação do concreto desta série aos 3 dias, 7 dias, 15 dias e 28 dias.

O módulo de elasticidade do concreto da série $\mathrm{G}$ teve um acréscimo de 3 dias para 15 dias, havendo um pequeno decréscimo de 15 dias para 28 dias.

A relação entre a resistência média à tração $(4,78 \mathrm{MPa})$ e a resistência média à compressão $(63,71 \mathrm{MPa})$ para o concreto da série $\mathrm{G}$ ficou em 7,46\%.

\section{3 - ENSAIOS DOS MODELOS DE PILARES}

\subsection{1 - MODELOS PILOTOS}

\section{Piloto 1}

O modelo de pilar de concreto contendo fibras de polipropileno, teve ruptura sem desagregações, com o cobrimento sendo descolado no instante da ruptura. Este permaneceu junto à armadura, sem se destacar completamente. Houve fissuração na parte superior do pilar junto à face mais comprimida, visto que a força aplicada não estava exatamente centrada. Esta fissuração ocorreu próxima à extremidade superior do elemento, quando a força era de $2000 \mathrm{kN}$.

Na figura 4.8 pode ser visto o comportamento da armadura longitudinal e transversal através dos diagramas tensão x deformação para o pilar Piloto 1 .

Os gráficos que estão posicionados na parte negativa do eixo das abscissas são relativos às barras comprimidas, que foram as barras longitudinais, com os dados lidos nos canais de 1 a 4, e os gráficos indicados na parte positiva do eixo das deformações indicam os estribos, nos canais de 5 a 8 . 


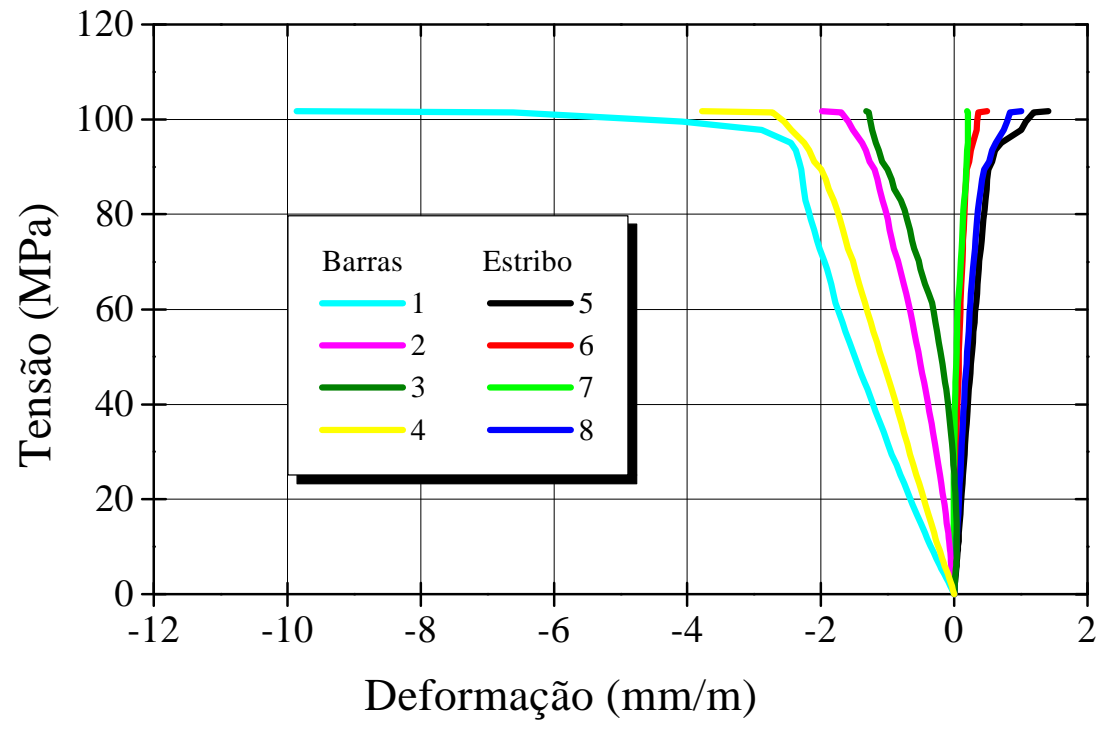

FIGURA 4.8 - Diagramas Tensão x Deformação para o Aço - Piloto 1

Na figura 4.9 se apresentam os diagramas tensão x deformação para os canais numerados de 9 a 12, colocados na face de concreto do pilar em questão. A seção em que ocorreu a ruptura era próxima à metade da altura do pilar, com força última de $2.402 \mathrm{kN}$ e com deformação máxima do concreto de $2,72 \%$, em uma das leituras.

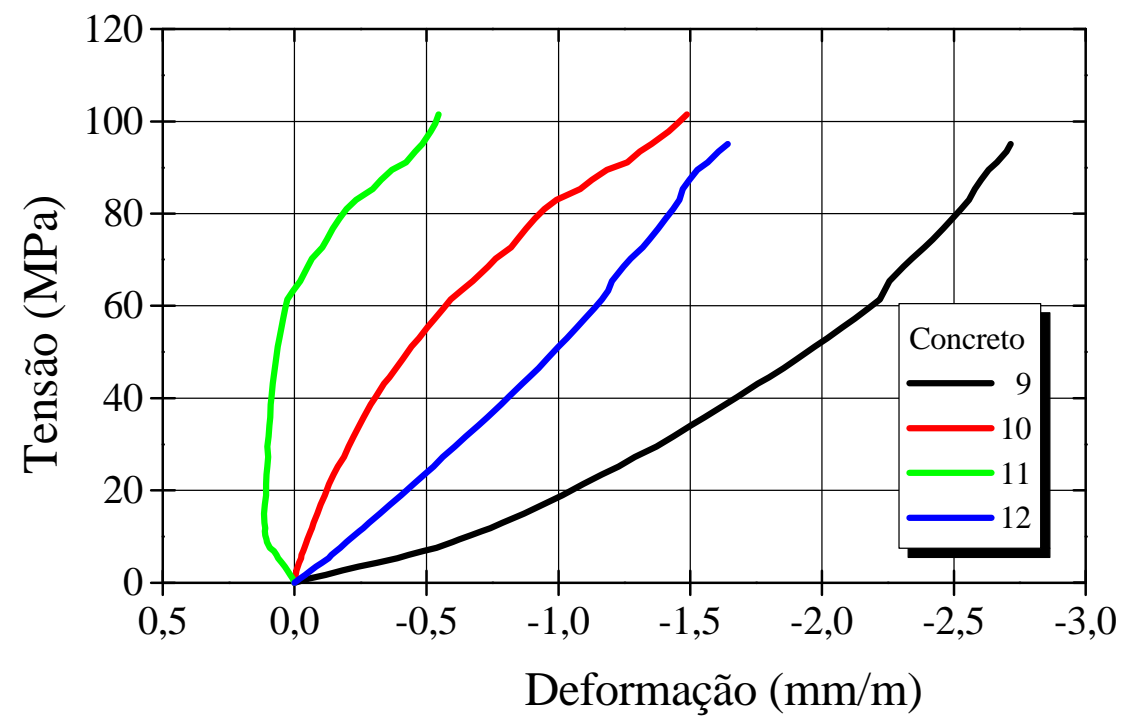

FIGURA 4.9 - Diagramas Tensão x Deformação para o Concreto - Piloto 1 


\section{Piloto 2}

O modelo de pilar de concreto de alta resistência contendo $0,50 \%$ de fibras metálicas e taxa de armadura transversal de 1,63\% não teve ruptura com desagregação do material, mas o cobrimento foi separado da armadura no instante da ruína. Próximo à etapa de força de $1900 \mathrm{kN}$, houve fissuração na parte superior do pilar, na região de aplicação da força, como pode ser visto na figura 4.10.

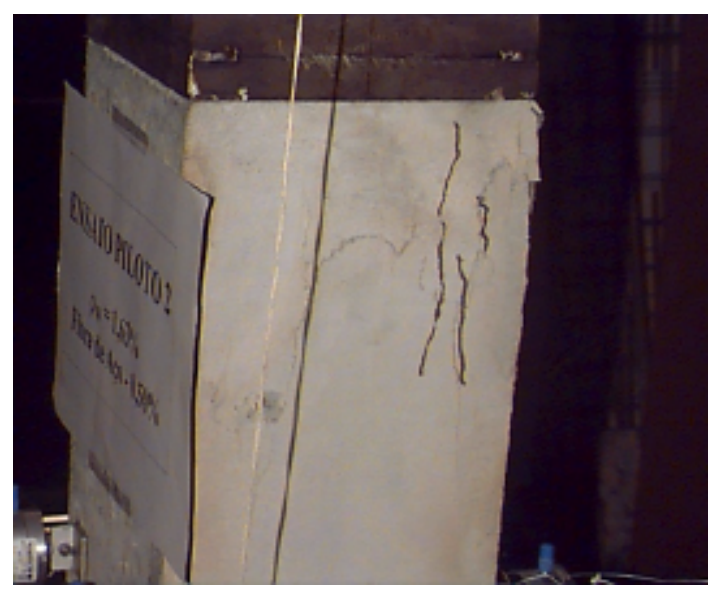

FIGURA 4.10 - Primeiras Fissuras - Piloto 2

Entretanto, a ruptura se deu em seção transversal próxima à metade da altura do pilar, com força última de $2.216 \mathrm{kN}$ e deformação máxima do concreto, em uma das leituras, de 2,14\%o, com configuração final podendo ser vista na figura 4.11.

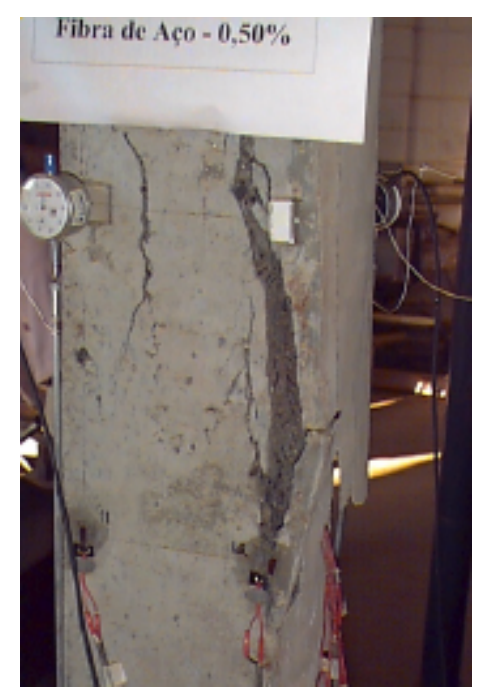

FIGURA 4.11 - Forma de Ruptura do Pilar Piloto 2 
Os diagramas tensão x deformação da armadura longitudinal e transversal para o pilar 2, podem ser vistos na figura 4.12.

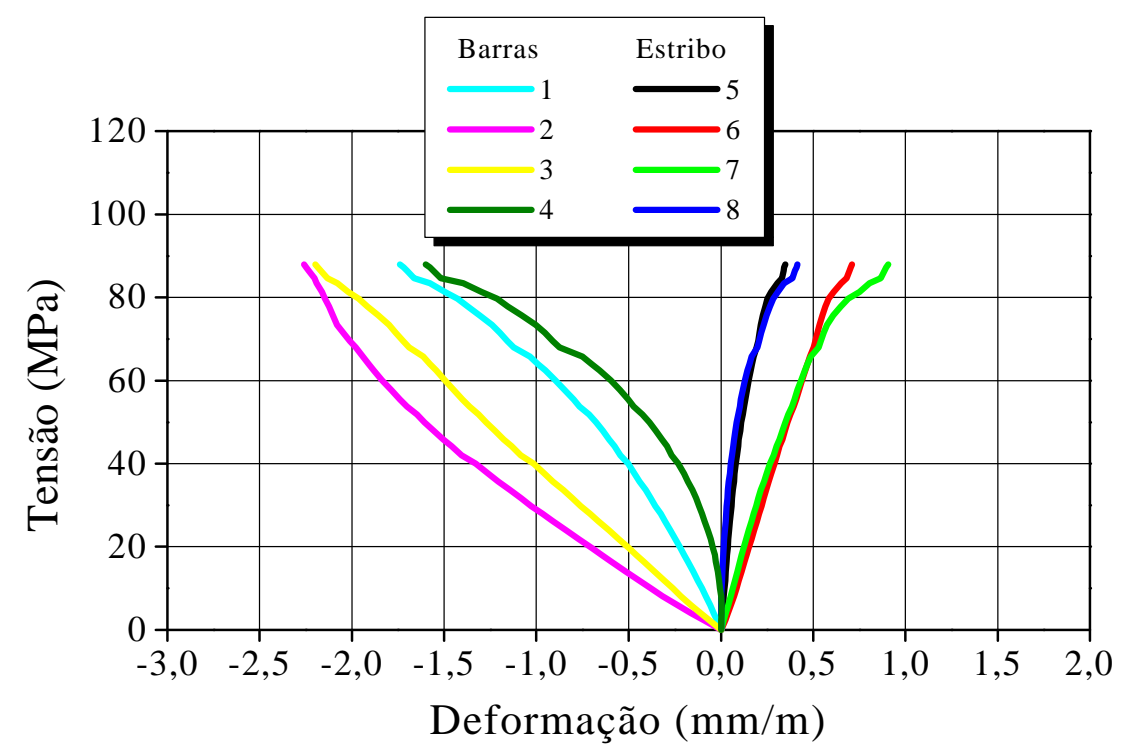

FIGURA 4.12 - Diagramas Tensão x Deformação para o Aço - Piloto 2

Os diagramas tensão x deformação para o concreto estão mostrados na figura 4.13.

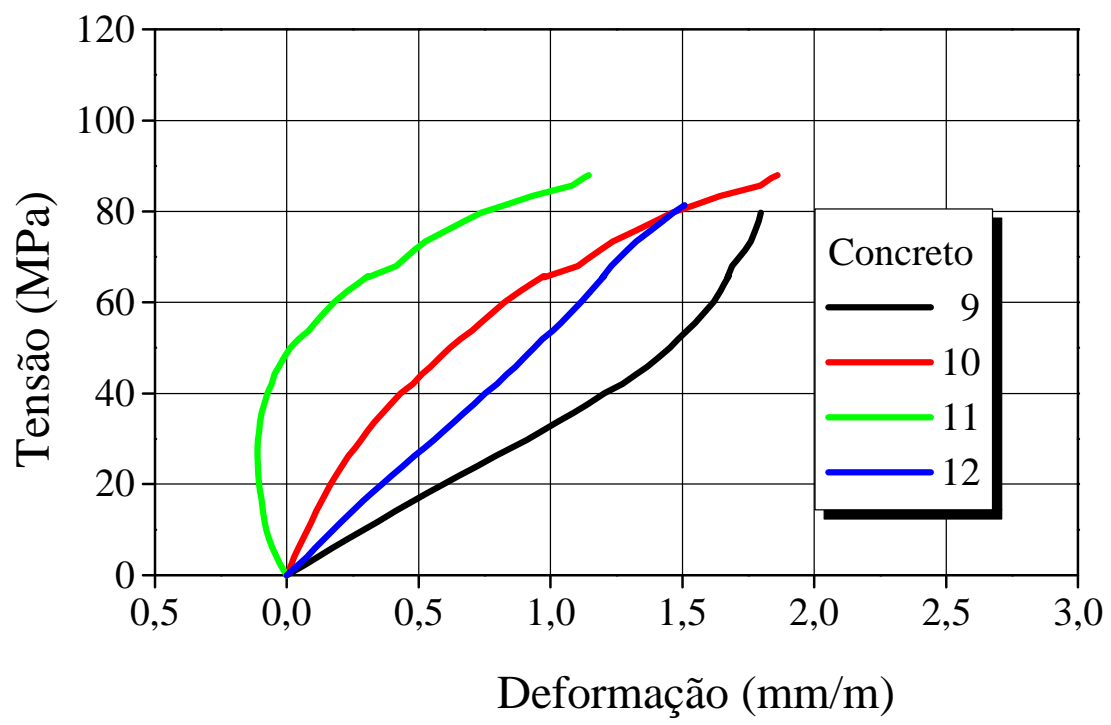

FIGURA 4.13 - Diagramas Tensão x Deformação para o Concreto - Piloto 2 


\section{Piloto 3}

O modelo de pilar de concreto com taxa de fibras metálicas de 1,00\% e taxa de armadura transversal de $0,82 \%$ teve ruptura com um pouco de desagregação do material, mas não houve estilhaçamento do cobrimento.

A força aplicada no pilar piloto 3 estava mais centrada que aquela aplicada nos outros dois pilares, e na ruína houve a flambagem das barras da armadura longitudinal na seção próxima à metade da altura. A configuração de ruptura do pilar 3 pode ser vista na figura 4.14 .

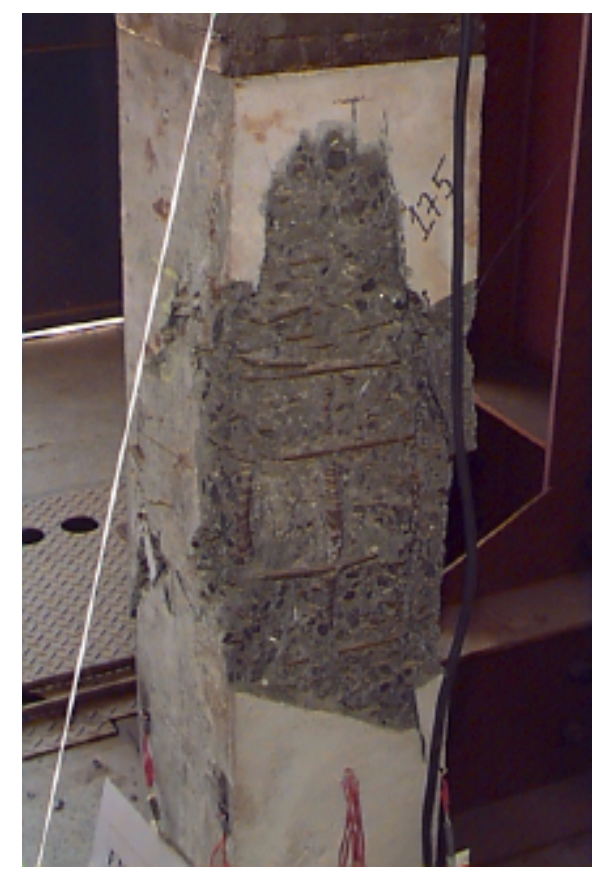

FIGURA 4.14 - Ruptura do Pilar Piloto 3

A força última foi de $2.432 \mathrm{kN}$ e a deformação máxima do concreto foi de 2,38\%o, em uma das leituras. Na figura 4.15 são mostrados os diagramas tensão $\mathrm{x}$ deformação das barras longitudinais e dos estribos para o pilar piloto 3. 


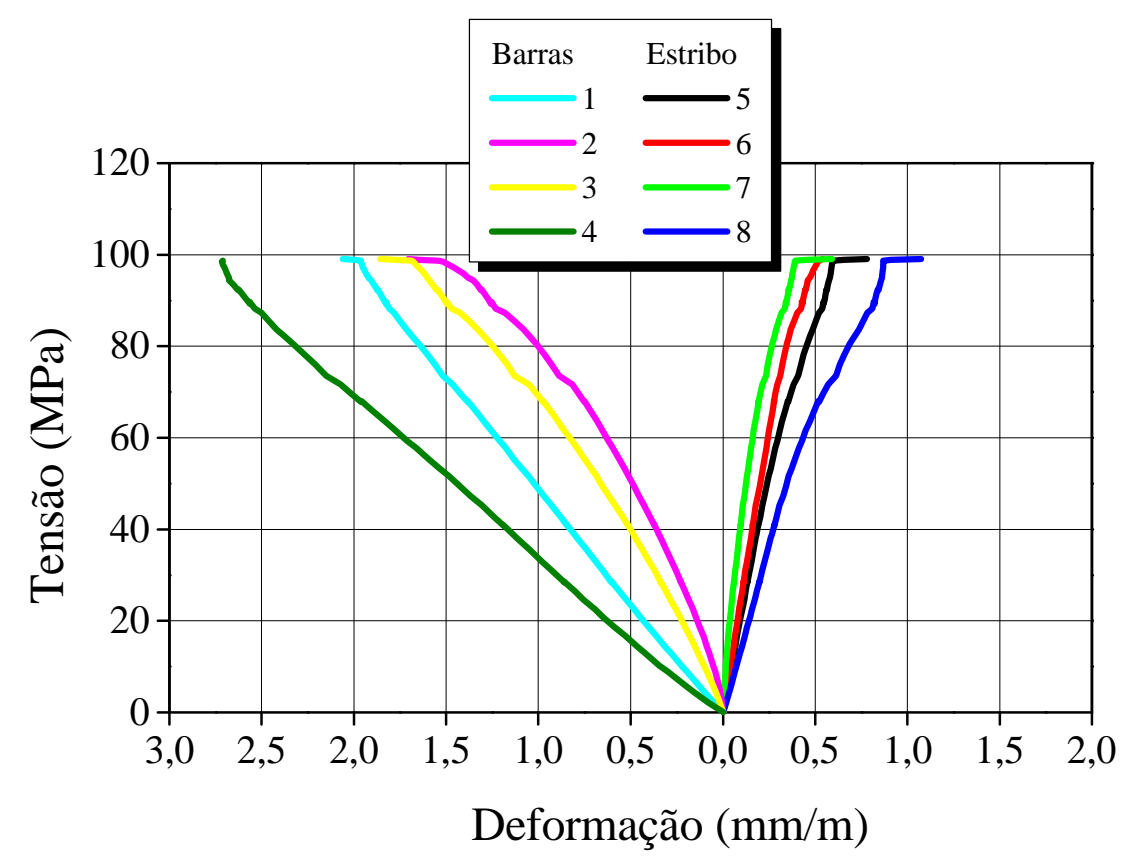

FIGURA 4.15 - Diagramas Tensão x Deformação para o Aço - Piloto 3

Os diagramas tensão $\mathrm{x}$ deformação, observados com os defletômetros mecânicos instalados nas faces de concreto do pilar, são mostrados na figura 4.16.

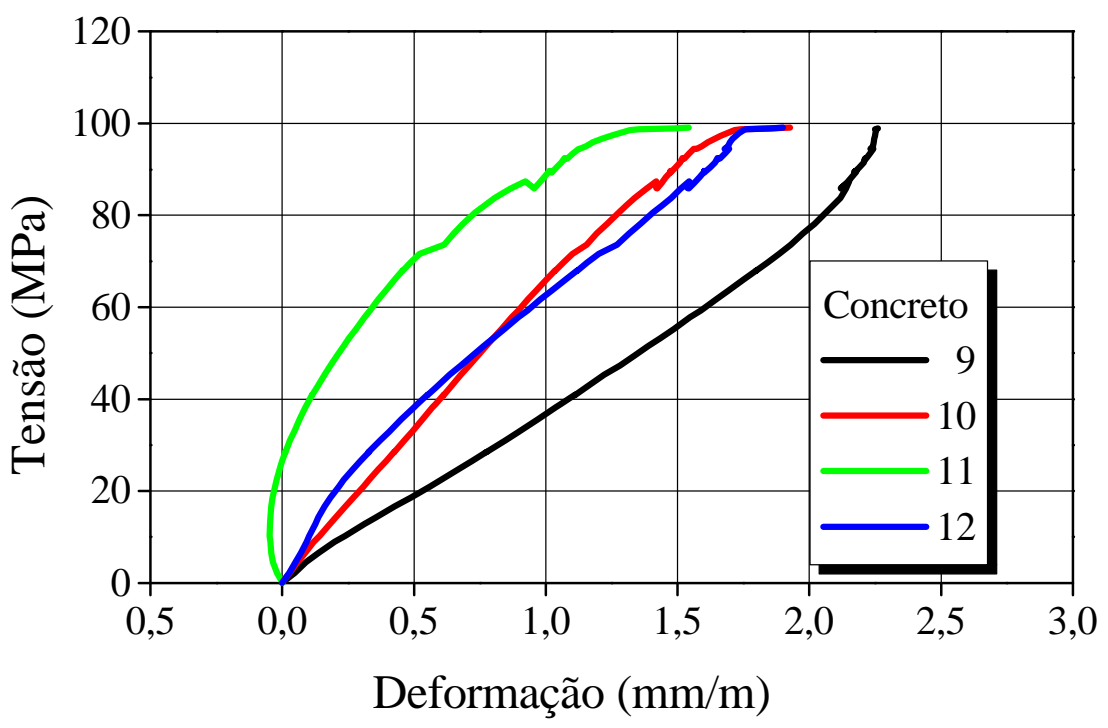

FIGURA 4.16 - Diagramas Tensão x Deformação para o Concreto - Piloto 3 


\subsubsection{1 - Resultados Teóricos}

Para se calcularem as forças últimas teóricas, utilizou-se a fórmula 4.1.

$$
F_{\text {un,teo }}=\left(A_{c n}-A_{s}\right) f_{c}+A_{s} f_{y}
$$

onde:

$\mathrm{A}_{\mathrm{cn}} \quad=$ área da seção transversal do núcleo do pilar;

$\mathrm{A}_{\mathrm{s}} \quad=$ área de armadura longitudinal;

$\mathrm{f}_{\mathrm{c}}=$ resistência média do concreto avaliada no dia do ensaio do modelo, multiplicado por um coeficiente, adotado igual a 0,9, para se levar em conta as relações entre as resistências obtidas nos corpos-de-prova e a real que atua no concreto da estrutura.

$\mathrm{f}_{\mathrm{y}} \quad=$ resistência média de escoamento do aço.

A tabela 4.1 mostra os resultados dos ensaios pilotos, comparando as forças últimas experimentais com as teóricas.

Tabela 4.1 - Comparação de $\mathrm{F}_{\mathrm{u} / \mathrm{exp}} / \mathrm{F}_{\mathrm{u} / \text { teo }}$

\begin{tabular}{|c|c|c|c|c|c|c|c|c|c|}
\hline Pilar & Fibra & $\mathbf{V}_{\mathbf{f}}$ & $\begin{array}{c}\mathbf{f}_{\mathbf{c m}} \\
(\mathbf{M P a})\end{array}$ & $\mathbf{E s t r i b o s}$ & $\begin{array}{c}\rho_{\mathbf{w}} \\
(\boldsymbol{\%})\end{array}$ & $\begin{array}{c}\mathbf{A}_{\mathbf{c n}} \\
\left(\mathbf{c m}^{\mathbf{2}}\right)\end{array}$ & $\begin{array}{c}\mathbf{F}_{\mathbf{u}, \mathbf{e x p}} \\
(\mathbf{k N})\end{array}$ & $\begin{array}{c}\mathbf{F}_{\text {un,teo }} \\
(\mathbf{k N})\end{array}$ & $\begin{array}{c}\mathbf{F}_{\mathbf{u} \text {,exp }} \\
/ \mathbf{F}_{\text {un,teo }}\end{array}$ \\
\hline Piloto 1 & Polip & $0,50 \%$ & 75,46 & $\phi 6,3 \mathrm{c} / 5$ & 1,63 & 236,24 & 2.402 & 2.075 & 1,16 \\
\hline Piloto 2 & Aço & $0,50 \%$ & 71,07 & $\phi 6,3 \mathrm{c} / 5$ & 1,63 & 251,86 & 2.216 & 1.986 & 1,12 \\
\hline Piloto 3 & Aço & $1,00 \%$ & 68,06 & $\phi 6,3 \mathrm{c} / 10$ & 0,82 & 245,55 & 2.432 & 1.924 & 1,26 \\
\hline
\end{tabular}

Na figura 4.17, são mostradas as curvas tensão x deformação do concreto para cada modelo piloto, com as deformações medidas nas faces dos pilares, onde se tem, como conclusão parcial, que o concreto do pilar contendo mais fibras de aço (piloto 3) se deformou mais que os outros pilares cujos concretos continham fibras metálicas em menor quantidade e fibras de polipropileno. 


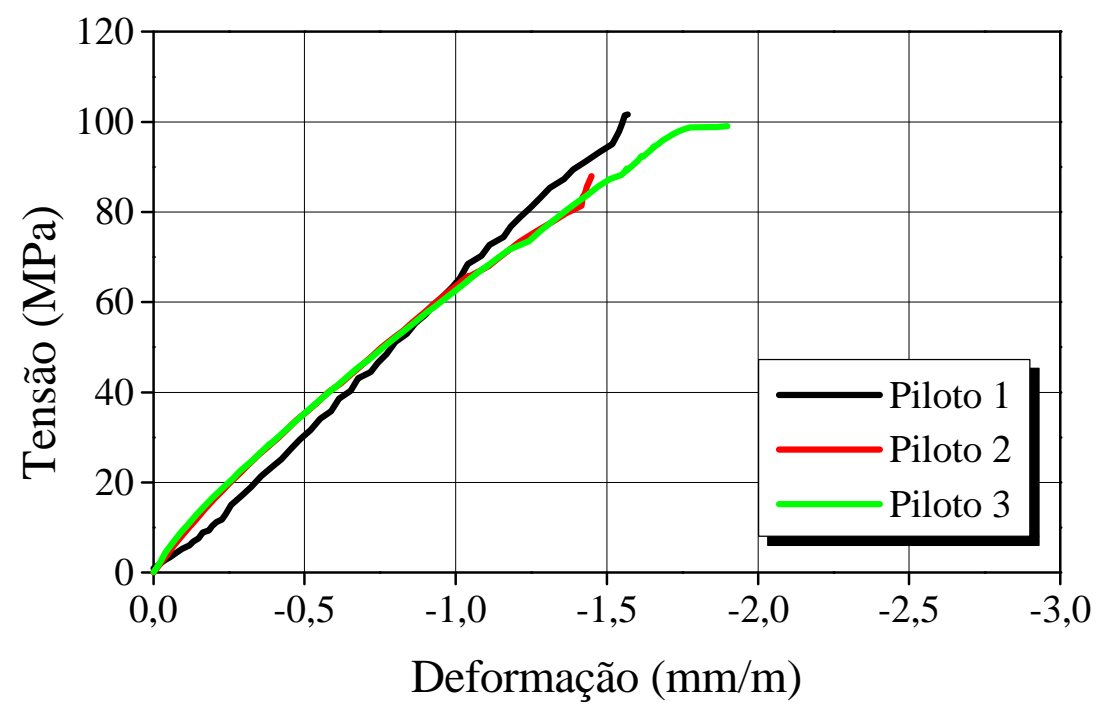

FIGURA 4.17 - Diagramas Tensão x Deformação dos Concretos dos 3 Pilares Ensaiados

Na figura 4.18 podem ser vistos os diagramas Tensão x Deformação dos pilares, com os respectivos deslocamentos lidos pelos defletômetros mecânicos.

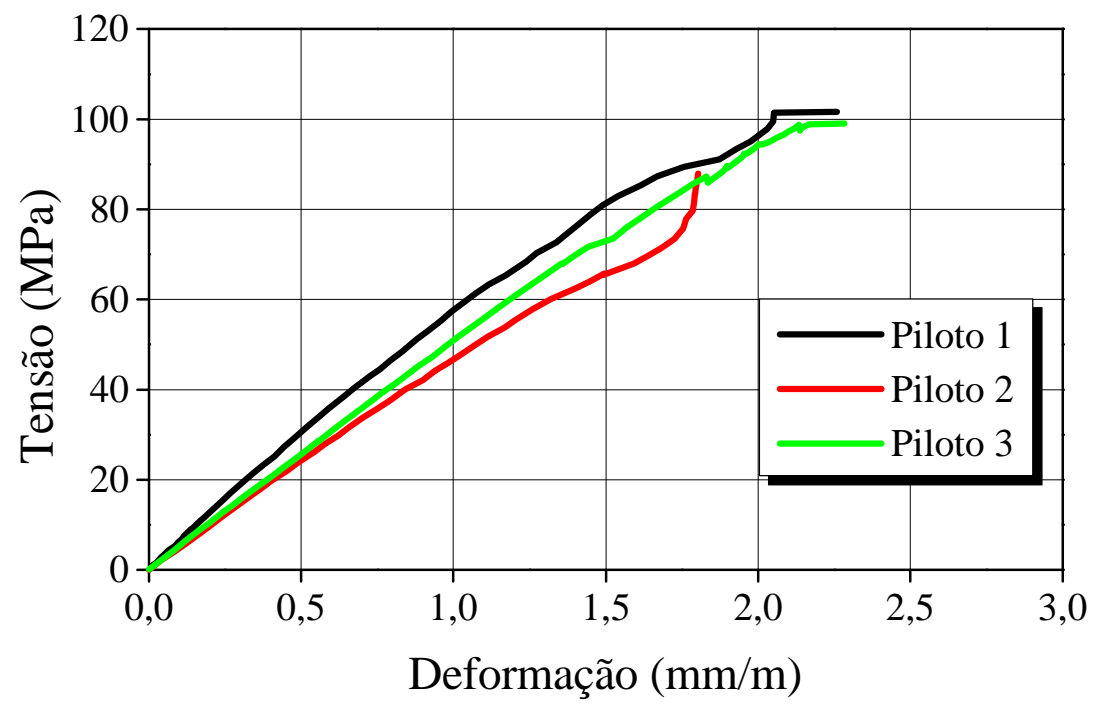

FIGURA 4.18 - Diagramas Tensão x Deformação dos Pilares 
Através dos resultados obtidos com os ensaios pilotos, pôde-se chegar a algumas conclusões quanto a necessidade de se fazerem algumas modificações para os ensaios dos modelos das séries de pilares.

Uma delas foi que as fibras metálicas usadas nesta etapa, não funcionaram adequadamente, pois percebeu-se a ruptura das mesmas junto com a ruína do concreto. Escolheu-se portanto, fibras de comprimento e resistência mecânica maiores para os modelos subseqüentes.

Outra modificação foi quanto ao posicionamento dos transdutores de deslocamento, como foi descrito no capítulo 4.

\subsection{2 - SÉRIES DE PILARES}

A seguir serão mostrados os resultados dos ensaios com os corpos-de-prova que foram moldados juntos com os pilares das séries principais, submetidos a ensaios de compressão axial com controle de força, para que fosse medida a resistência média à compressão, ensaios à compressão diametral, para que fosse medida a resistência média à tração, e ensaios à compressão axial com controle de deformação, para que fosse medido o índice de tenacidade do concreto com fibras, e definido o módulo de elasticidade.

\subsubsection{1 - Resistência Média à Compressão}

$\mathrm{Na}$ tabela 4.2 pode ser visto um resumo dos valores médios obtidos nos ensaios dos corpos-de-prova submetidos à compressão.

Esses testes foram feitos em máquina eletrônica, com controle de força, no Laboratório de Engenharia de Estruturas, a menos dos corpos-de-prova das séries P2a15 e P2a10, os quais foram testados no Laboratório de Construção Civil.

São mostradas nesta tabela as resistências médias à compressão dos corposde-prova com 7 dias de idade e com 15 dias, data em que eram feitos os ensaios dos pilares. $\mathrm{O}$ valor médio é resultados do ensaio de três corpos-de-prova. 
Tabela 4.2 - Resistências Médias à Compressão das Séries de Pilares

\begin{tabular}{|c|c|c|c|c|}
\hline Série & $\begin{array}{l}V_{f} \\
(\%)\end{array}$ & $\begin{array}{c}\mathbf{f}_{\mathrm{cm}}(7 \text { dias }) \\
(\mathrm{MPa})\end{array}$ & \multicolumn{2}{|c|}{$\begin{array}{c}\mathbf{f}_{\mathrm{cm}}(15 \text { dias }) \\
(\mathrm{MPa})\end{array}$} \\
\hline P1a15 & 0,25 & - & $81,03(\mathrm{P} 1)$ & $87,81(\mathrm{P} 2)$ \\
\hline P1a10 & 0,25 & 69,82 & \multicolumn{2}{|c|}{85,47} \\
\hline $\mathrm{P} 1 \mathrm{a} 05$ & 0,25 & 68,51 & \multicolumn{2}{|c|}{80,68} \\
\hline P2a15 & 0,50 & 61,16 & \multicolumn{2}{|c|}{71,85} \\
\hline P2a15-r & 0,50 & 54,75 & \multicolumn{2}{|c|}{66,46} \\
\hline $\mathrm{P} 2 \mathrm{a} 10$ & 0,50 & 61,87 & \multicolumn{2}{|c|}{79,98} \\
\hline $\mathrm{P} 2 \mathrm{a} 05$ & 0,50 & 63,58 & \multicolumn{2}{|c|}{77,63} \\
\hline P3a15 & 1,00 & 58,91 & \multicolumn{2}{|c|}{77,08} \\
\hline P3a10 & 1,00 & 48,87 & \multicolumn{2}{|c|}{65,02} \\
\hline $\mathrm{P} 3 \mathrm{a} 05$ & 1,00 & 66,55 & \multicolumn{2}{|c|}{69,04} \\
\hline P4a15 & 0,75 & 66,47 & \multicolumn{2}{|c|}{79,87} \\
\hline $\mathrm{P} 4 \mathrm{a} 10$ & 0,75 & 72,49 & \multicolumn{2}{|c|}{86,45} \\
\hline $\mathrm{P} 4 \mathrm{a} 05$ & 0,75 & 63,74 & \multicolumn{2}{|c|}{75,54} \\
\hline P3p10 & 0,50 & 57,36 & \multicolumn{2}{|c|}{57,06} \\
\hline
\end{tabular}

\subsubsection{2 - Resistência Média à Tração}

Na tabela 4.3, pode ser visto um resumo das resistências médias à tração do concreto dos modelos e a relação entre a resistência média à tração e a resistência média à compressão, ambos realizados aos 15 dias. As médias são relativas a três corpos-de-prova.

Os ensaios dos corpos-de-prova submetidos a compressão diametral para obtenção da resistência média à tração foram feitos no Laboratório de Estruturas, da Escola de Engenharia de São Carlos, a menos das séries P2a15 e P2a10, cujos corpos-de-prova foram ensaiados no Laboratório de Construção Civil.

Com os resultados mostrados na tabela 4.3 , pode-se observar que a relação entre a resistência média à tração e a resistência média à compressão aumenta com o aumento da quantidade de fibras no concreto. 
Tabela 4.3 - Resistências Médias à Tração das Séries de Pilares

\begin{tabular}{|c|c|c|c|}
\hline Série & $\begin{array}{c}\mathbf{V}_{\mathbf{f}} \\
(\boldsymbol{\%})\end{array}$ & $\begin{array}{c}\mathbf{f}_{\text {ctm }}(\mathbf{1 5} \text { dias }) \\
(\mathbf{M p a})\end{array}$ & $\begin{array}{c}\mathbf{f}_{\mathbf{c t m}} / \mathbf{f}_{\mathbf{c m}} \\
(\boldsymbol{\%})\end{array}$ \\
\hline P1a15 & 0,25 & - & - \\
\hline P1a10 & 0,25 & 5,35 & 6,26 \\
\hline P1a05 & 0,25 & 5,20 & 6,45 \\
\hline P2a15 & 0,50 & 5,87 & 8,17 \\
\hline P2a15-r & 0,50 & 4,68 & 7,00 \\
\hline P2a10 & 0,50 & 6,27 & 7,84 \\
\hline P2a05 & 0,50 & 5,94 & 7,70 \\
\hline P3a15 & 1,00 & 8,58 & 11,13 \\
\hline P3a10 & 1,00 & 8,40 & 12,91 \\
\hline P3a05 & 1,00 & 7,90 & 11,45 \\
\hline P4a15 & 0,75 & 6,55 & 8,19 \\
\hline P4a10 & 0,75 & 7,98 & 9,25 \\
\hline P4a05 & 0,75 & 6,63 & 8,77 \\
\hline P3p10 & 0,50 & 4,89 & 8,56 \\
\hline
\end{tabular}

\subsubsection{3 - Ensaios com Deformação Controlada dos Corpos-de-Prova}

Os valores foram obtidos com a média de quatro corpos-de-prova, a menos do índice de tenacidade que foi obtido com a média de apenas três. Os ensaios com os corpos-de-prova foram feitos no mesmo dia dos ensaios dos pilares, mas por problemas de cronograma do Laboratório de Geotecnia, algumas vezes os ensaios com os corpos-de-prova eram realizados posteriormente aos dos pilares, em questão de dias. Por isso a diferença de resultados entre as resistências médias à compressão da tabela 4.2 com os resultados mostrados na tabela 4.4, onde é possível encontrar as resistências médias à compressão, o módulo de elasticidade médio, o coeficiente de Poisson médio e o índice de tenacidade médio, seguindo a JSCE-SF5(1984), para o concreto de cada série de pilares.

Os resultados indicam um aumento do índice de tenacidade com o aumento da quantidade de fibras adicionadas ao concreto, mesmo nos ensaios à compressão dos corpos-de-prova. 
Para cada série de pilares foram ensaiados 4 corpos-de-prova com controle de deformação, mas foram selecionados apenas três resultados para que fosse medido o índice de tenacidade do material.

Tabela 4.4 - Ensaios com Deformação Controlada

\begin{tabular}{|c|c|c|c|c|c|}
\hline Corpo & Taxa de & Resistência à & Módulo de & Coeficiente & Índice de \\
- de - & Fibras & Compressão & Elasticidade & De & Tenacidade \\
Prova & $(\%)$ & $(\mathbf{M P a})$ & $(\mathbf{G P a})$ & Poisson & ${\overline{\sigma_{\mathbf{c}}}}^{\text {(MPa) }}$ \\
\hline P1a15 & 0,25 & - & - & - & - \\
\hline P1a10 & 0,25 & 77,40 & 29,91 & 0,19 & 42,10 \\
\hline P1a05 & 0,25 & 76,24 & 28,81 & 0,11 & 43,21 \\
\hline P2a15 & 0,50 & 64,96 & 27,41 & 0,16 & 43,30 \\
\hline P2a15-r & 0,50 & - & - & - & - \\
\hline P2a10 & 0,50 & 69,90 & 29,64 & 0,17 & 46,60 \\
\hline P2a05 & 0,50 & 86,97 & 29,18 & 0,12 & 52,86 \\
\hline P3a15 & 1,00 & 74,78 & 31,01 & 0,12 & 51,80 \\
\hline P3a10 & 1,00 & 69,18 & 28,17 & 0,16 & 55,60 \\
\hline P3a05 & 1,00 & 76,17 & 28,73 & 0,15 & 53,32 \\
\hline P4a15 & 0,75 & 85,57 & 30,10 & - & 57,23 \\
\hline P4a10 & 0,75 & 92,30 & 29,41 & 0,21 & 60,25 \\
\hline P4a05 & 0,75 & 81,77 & 28,71 & 0,15 & 53,22 \\
\hline P3p10 & 0,50 & 63,69 & 23,86 & 0,17 & 35,56 \\
\hline
\end{tabular}

As curvas força $\mathrm{x}$ deslocamento escolhidas para o cálculo dos índices de tenacidade das séries P1a05, P1a10 e P1a15, cujo concreto tinha 0,25\% de taxa volumétrica de fibras de aço, são mostradas na figura 4.19.

A ruptura dos corpos-de-prova destas séries se mostraram um pouco bruscas, em função da alta resistência do concreto e da quantidade de fibras, que foi a menor utilizada na pesquisa. Nas outras séries a ruptura dos corpos-de-prova foi mais dúctil, devido ao aumento gradativo da adição de fibras, e quanto maior era esta adição, menos brusca era a ruptura dos corpos-de-prova.

No Anexo A é possível encontrar todos os resultados destes ensaios, sendo as curvas mostradas isoladamente. 


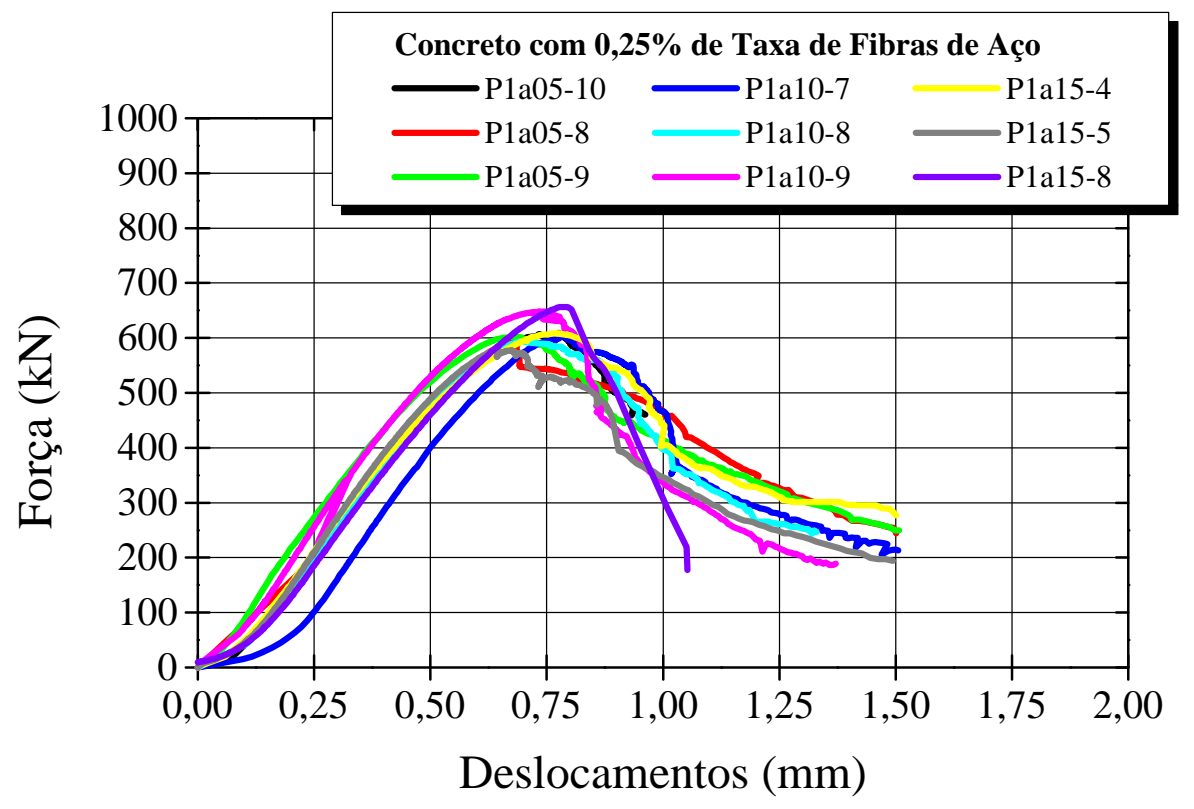

FIGURA 4.19 - Curvas Força x Deslocamentos P1a05, P1a10 e P1a15

$\mathrm{Na}$ figura 4.20 podem ser vistas as curvas dos corpos-de-prova das séries P2a05, P2a10 e P2a15, que foram escolhidas para o cálculo do índice de tenacidade das respectivas séries de pilares.

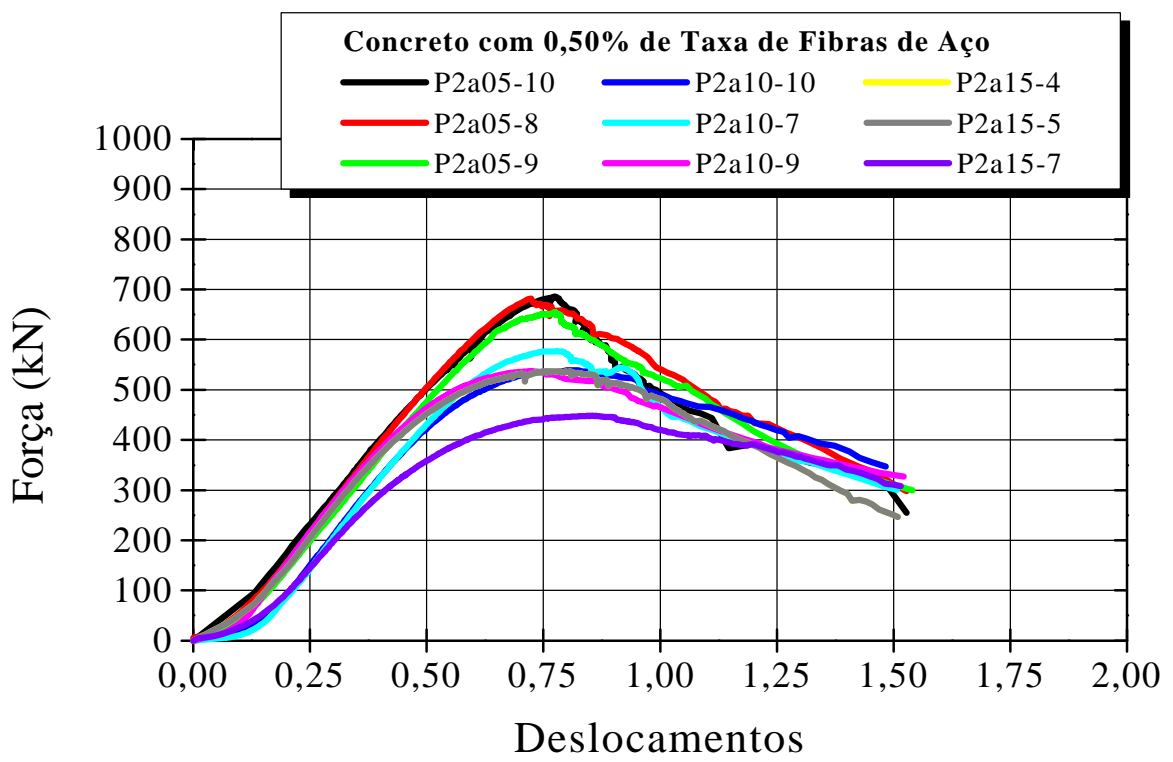

FIGURA 4.20 - Curvas Força x Deslocamentos P2a05, P2a10 e P2a15 
Na figura 4.21 estão as curvas usadas para o cálculo do índice de tenacidade dos concretos das séries de pilares P3a05, P3a10 e P3a15.

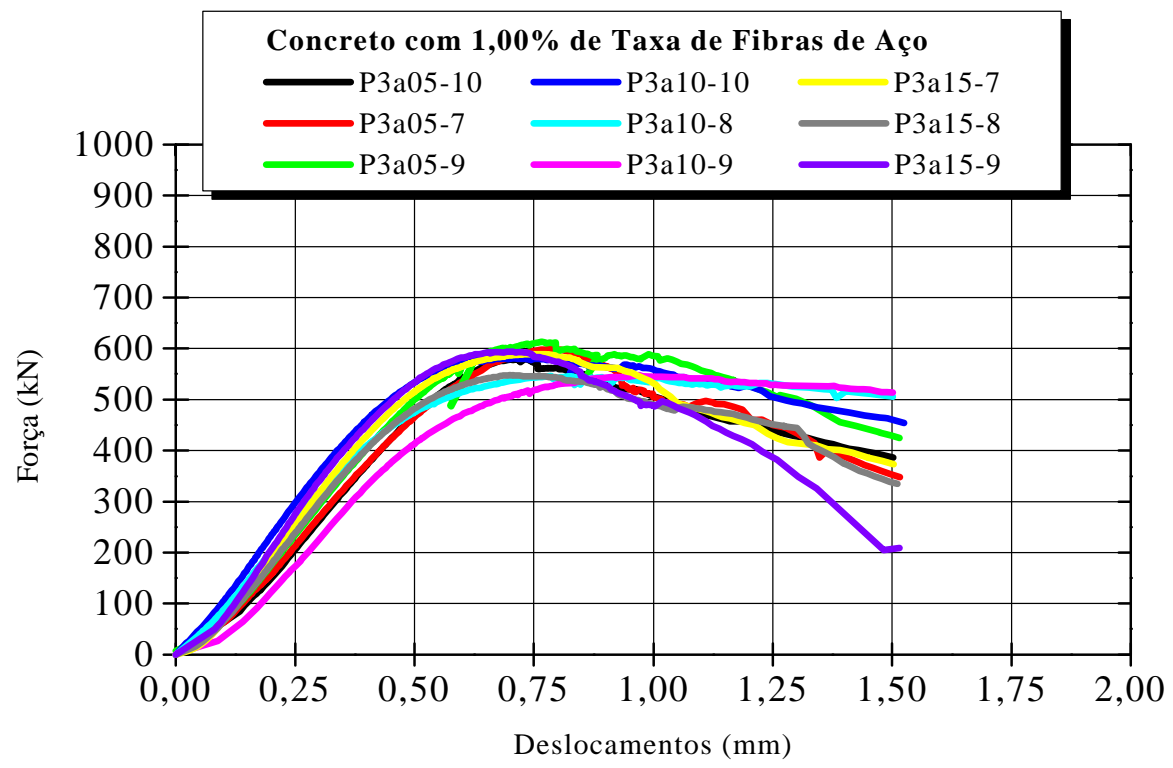

FIGURA 4.21 - Curvas Força x Deslocamentos P3a05, P3a10 e P3a15

As curvas usadas para o cálculo do índice de tenacidade das séries P4a05, P4a10 e P4a15 são mostradas na figura 4.22.

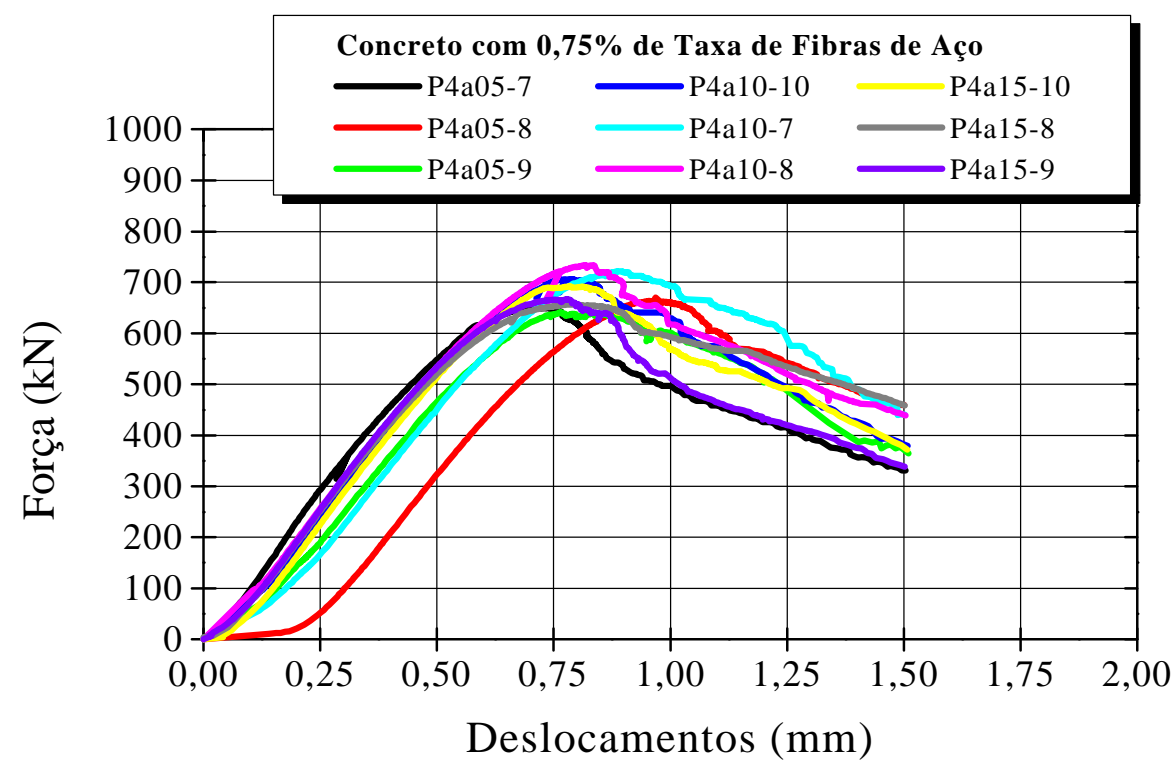

FIGURA 4.22 - Curvas Força x Deslocamentos P4a05, P4a10 e P4a15 
O concreto da última série de pilares ensaiada, P3a10, continha fibras de polipropileno e as curvas dos ensaios dos corpos-de-prova submetidos à compressão axial com deformação controlada são mostradas na figura 4.23 .

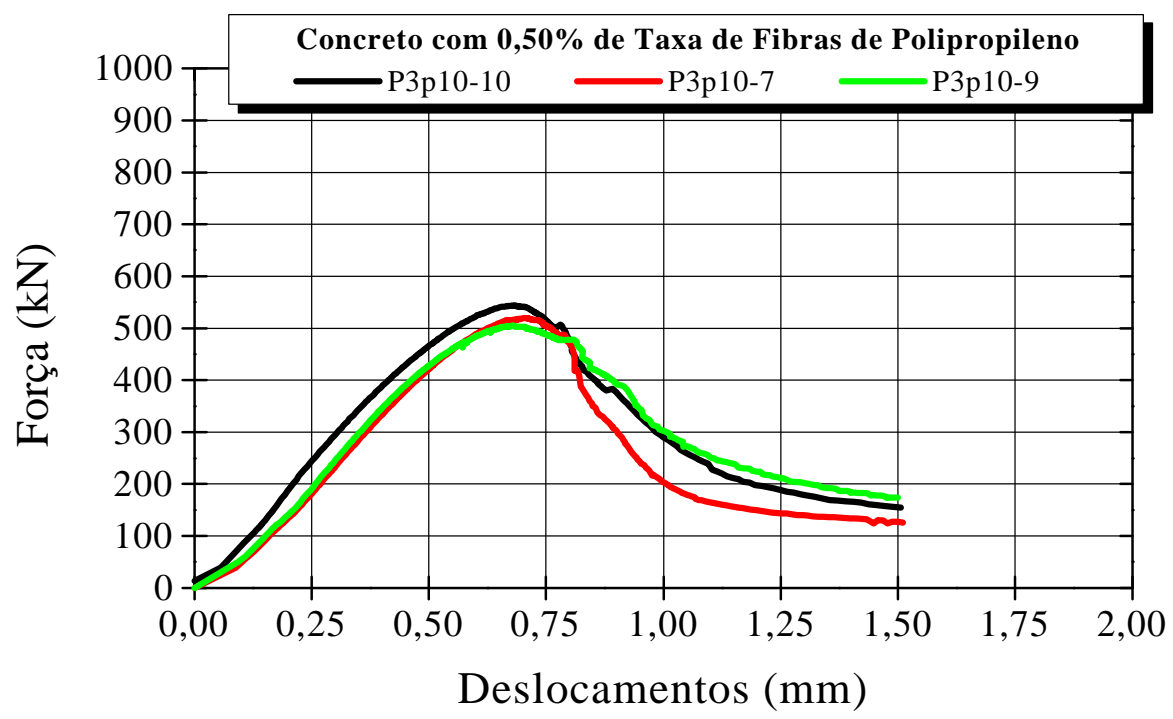

FIGURA 4.23 - Curvas Força x Deslocamentos P3p10

É possível perceber que com o aumento da adição de fibras, a parte descendente da curva tensão deformação vai se aproximando do comportamento elasto-plástico perfeito, mudando a característica do concreto de alta resistência de um material frágil para um material dúctil.

Pode-se perceber ao comparar os índices de tenacidade do concreto com fibras metálicas com o concreto com fibras de polipropileno contendo a mesma taxa volumétrica de $0,50 \%$, que o concreto contendo fibras metálicas, possuindo um valor maior do índice e apresentado curvas com a parte descendente menos inclinada, é capaz de absorver mais energia na etapa pós-pico, devido a maior rigidez da fibra.

\subsubsection{4 - Resultados dos Ensaios dos Pilares}

$\mathrm{Na}$ tabela 4.5 constam os resultados dos ensaios de pilares de todas as séries que foram ensaiadas ao longo de aproximadamente um ano de trabalho no Laboratório de Estruturas. 
Tabela 4.5 - Resumo dos Ensaios dos Pilares

\begin{tabular}{|c|c|c|c|c|c|c|c|c|}
\hline Pilar & Fibras & $\begin{array}{c}V_{f} \\
(\%)\end{array}$ & Estribos & $\begin{array}{l}\rho_{\mathrm{w}} \\
(\%)\end{array}$ & 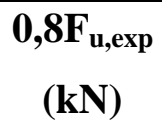 & $\begin{array}{c}\varepsilon_{0,8 \mathrm{Fu}, \exp } \\
\% 0\end{array}$ & $\begin{array}{c}\mathbf{F}_{\mathrm{u}, \exp } \\
(\mathbf{k N})\end{array}$ & $\begin{array}{c}\varepsilon_{\mathrm{u}, \exp } \\
\% \circ\end{array}$ \\
\hline P1a15-1 & Aço & 0,25 & $\phi 6,3 \mathrm{c} / 15$ & 0,55 & 1.958 & 1,62 & 2.453 & 2,07 \\
\hline P1a15-2 & Aço & 0,25 & $\phi 6,3 \mathrm{c} / 15$ & 0,55 & 2.173 & 1,50 & 2.714 & 2,02 \\
\hline P1a10-1 & Aço & 0,25 & $\phi 6,3 \mathrm{c} / 10$ & 0,82 & 2.056 & 1,62 & 2.581 & 2,26 \\
\hline P1a10-2 & Aço & 0,25 & $\phi 6,3 \mathrm{c} / 10$ & 0,82 & 1.864 & 1,45 & 2.304 & 2,06 \\
\hline P1a05-1 & Aço & 0,25 & $\phi 6,3 \mathrm{c} / 05$ & 1,63 & 1.864 & 1,53 & 2.291 & 2,42 \\
\hline P1a05-2 & Aço & 0,25 & $\phi 6,3 \mathrm{c} / 05$ & 1,63 & 1.965 & 1,52 & 2.449 & 2,62 \\
\hline P2a15-1 & Aço & 0,50 & $\phi 6,3 \mathrm{c} / 15$ & 0,55 & 1.763 & 1,46 & 2.208 & 2,09 \\
\hline P2a15-2 & Aço & 0,50 & $\phi 6,3 \mathrm{c} / 15$ & 0,55 & 1.445 & 1,23 & 1.827 & 1,83 \\
\hline $\mathrm{P} 2 \mathrm{a} 15-1 \mathrm{r}$ & Aço & 0,50 & $\phi 6,3 \mathrm{c} / 15$ & 0,55 & 1.454 & 1,55 & 1.840 & 3,38 \\
\hline $\mathrm{P} 2 \mathrm{a} 15-2 \mathrm{r}$ & Aço & 0,50 & $\phi 6,3 \mathrm{c} / 15$ & 0,55 & 1.457 & 1,33 & 1.841 & 2,31 \\
\hline P2a10-1 & Aço & 0,50 & $\phi 6,3 \mathrm{c} / 10$ & 0,82 & 2.328 & 1,47 & 2.911 & 2,09 \\
\hline P2a10-2 & Aço & 0,50 & $\phi 6,3 \mathrm{c} / 10$ & 0,82 & 2.419 & 1,48 & 3.028 & 1,89 \\
\hline $\mathrm{P} 2 \mathrm{a} 05-1$ & Aço & 0,50 & $\phi 6,3 \mathrm{c} / 05$ & 1,63 & 1.987 & 1,66 & 2.491 & 2,48 \\
\hline $\mathrm{P} 2 \mathrm{a} 05-2$ & Aço & 0,50 & $\phi 6,3 \mathrm{c} / 05$ & 1,63 & 2.042 & 1,74 & 2.554 & 2,36 \\
\hline P3a15-1 & Aço & 1,00 & $\phi 6,3 \mathrm{c} / 15$ & 0,55 & 2.005 & 1,38 & 2.509 & 1,87 \\
\hline P3a15-2 & Aço & 1,00 & $\phi 6,3 \mathrm{c} / 15$ & 0,55 & 1.870 & 1,21 & 2.360 & 2,03 \\
\hline P3a10-1 & Aço & 1,00 & $\phi 6,3 \mathrm{c} / 10$ & 0,82 & 1.923 & 1,47 & 2.373 & 2,28 \\
\hline P3a10-2 & Aço & 1,00 & $\phi 6,3 \mathrm{c} / 10$ & 0,82 & 1.757 & 1,33 & 2.164 & 2,11 \\
\hline P3a05-1 & Aço & 1,00 & $\phi 6,3 \mathrm{c} / 05$ & 1,63 & 1.856 & 1,77 & 2.333 & 2,91 \\
\hline P3a05-2 & Aço & 1,00 & $\phi 6,3 \mathrm{c} / 05$ & 1,63 & 1.984 & 1,55 & 2.454 & 2,74 \\
\hline P4a15-1 & Aço & 0,75 & $\phi 6,3 \mathrm{c} / 15$ & 0,55 & 2.067 & 1,43 & 2.584 & 2,09 \\
\hline P4a15-2 & Aço & 0,75 & $\phi 6,3 \mathrm{c} / 15$ & 0,55 & 2.091 & 1,62 & 2.609 & 2,30 \\
\hline P4a10-1 & Aço & 0,75 & $\phi 6,3 \mathrm{c} / 10$ & 0,82 & 2.104 & 1,38 & 2.603 & 1,80 \\
\hline P4a10-2 & Aço & 0,75 & $\phi 6,3 \mathrm{c} / 10$ & 0,82 & 2.098 & 1,74 & 2.598 & 2,91 \\
\hline $\mathrm{P} 4 \mathrm{a} 05-1$ & Aço & 0,75 & $\phi 6,3 \mathrm{c} / 05$ & 1,63 & 1.754 & 1,80 & 2.222 & 4,97 \\
\hline $\mathrm{P} 4 \mathrm{a} 05-2$ & Aço & 0,75 & $\phi 6,3 \mathrm{c} / 05$ & 1,63 & 1.761 & 1,69 & 2.199 & 2,47 \\
\hline P3p10-2 & Polip & 0,50 & $\phi 6,3 \mathrm{c} / 10$ & 0,82 & 1.900 & 3,08 & 2.391 & 4,33 \\
\hline
\end{tabular}

Como descrito no capítulo 3, as séries eram diferenciadas pela quantidade de fibras, tipo e espaçamento entre estribos. A taxa de armadura longitudinal geométrica, com a seção transversal total, foi constante e igual a $2,41 \%$, e a área do 
núcleo, devido ao fato dos estribos terem sido dobrados em gabarito, foi a mesma para todos os modelos, igual a $251,86 \mathrm{~cm}^{2}$.

Para cada série de pilares foram ensaiados dois modelos num pórtico de reação, e o controle da ação sobre os elementos era dado pelo controle de força. Apenas os pilares da série P3p10 foram ensaiados com controle de deformação, em máquina de ensaios universal da marca INSTRON, com capacidade para $3.000 \mathrm{kN}$ de força estática.

A figura 4.24 mostra o comportamento das forças últimas dos pilares com as taxas volumétricas de fibras que foram utilizadas neste trabalho. É possível notar que não houve influência das fibras nas forças últimas dos pilares, nem com acréscimos, nem com decréscimos. A variação da taxa de armadura transversal também não provocou aumento na força resistente experimental. Os valores diferenciados ocorridos para a taxa de fibras de $0,50 \%$, ocorreram devido a fatores de ensaios.

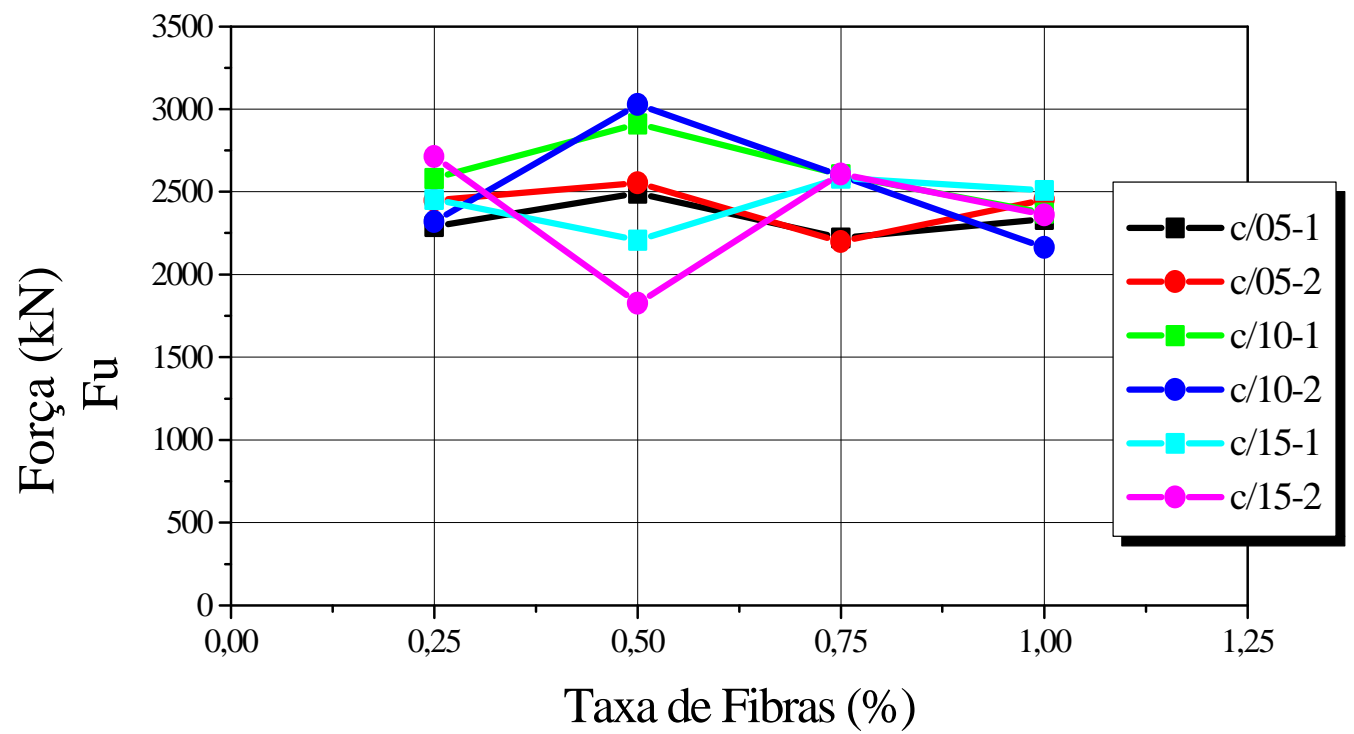

FIGURA 4.24 - Comportamento das Forças Últimas com as Taxas de Fibras

Na figura 4.25 é mostrado o comportamento das deformações dos pilares para as forças últimas, com as diferentes taxas de fibras.

É possível notar a influência da taxa de armadura transversal nas deformações últimas, indicando ductilidade dada pelos estribos, mesmo com configuração 
simples. As fibras tiveram pouca influência quanto às deformações últimas dos pilares submetidos à compressão axial, o que era esperado.

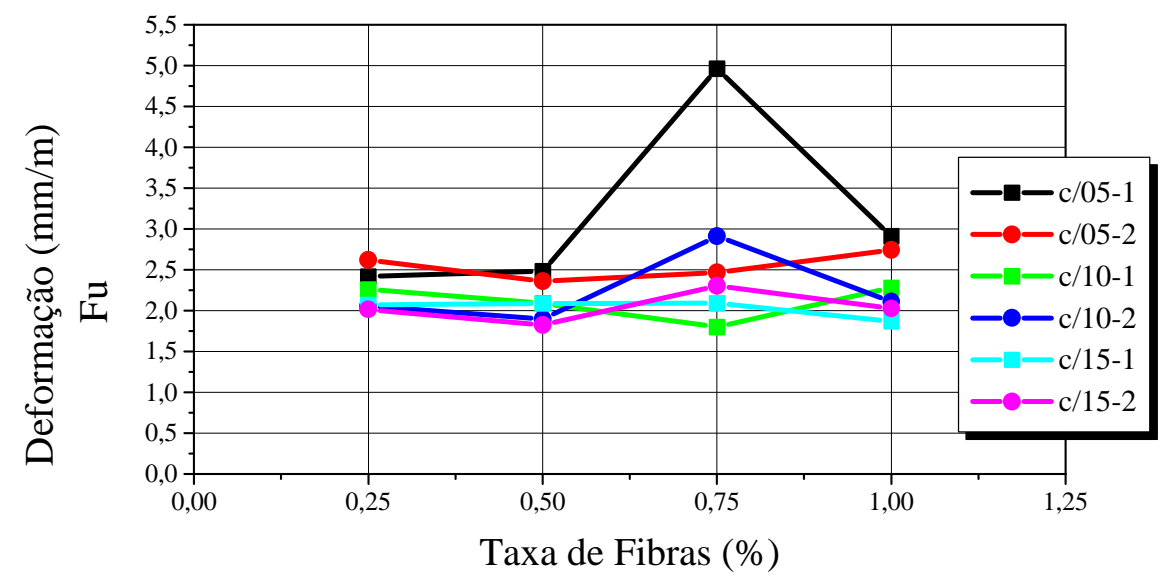

FIGURA 4.25 - Comportamento das Deformações para as Forças Últimas com as Taxas de Fibras

Para confirmar as conclusões obtidas acima, é mostrado na figura 4.26 o comportamento das deformações para força obtida à aproximadamente $80 \%$ da força última, onde o pilar encontrava-se em serviço.

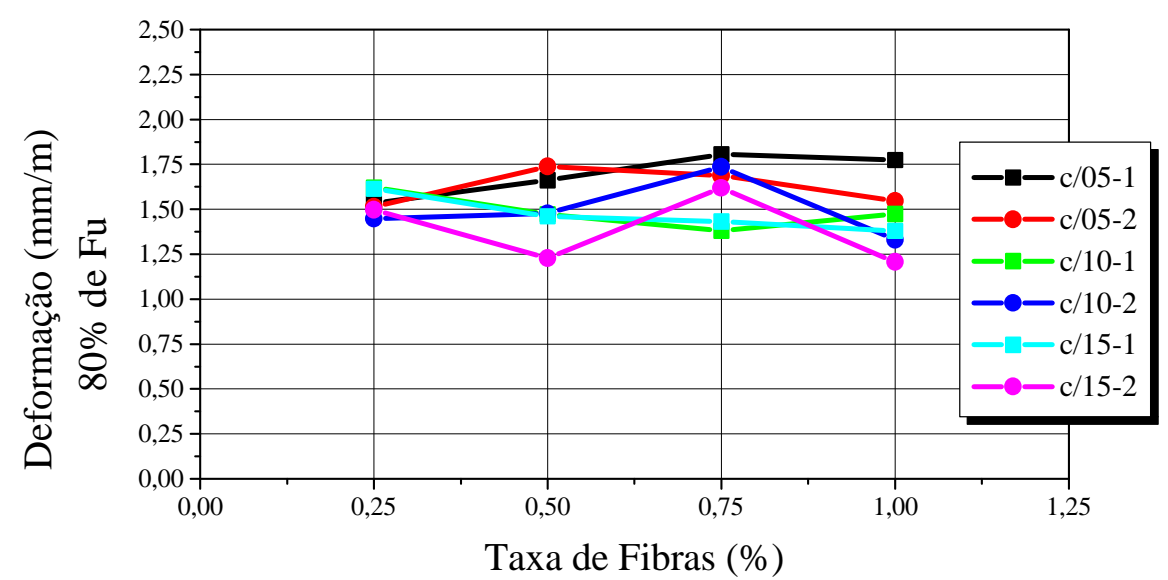

FIGURA 4.26 - Comportamento das Deformações à 80\% das Forças Últimas com as Taxas de Fibras 
É possível perceber, pela figura 4.26, um crescimento das deformações com o aumento da taxa de armadura transversal, como foi mostrado na figura 4.25. Portanto a influência das fibras em elementos de concreto submetidos à compressão está na ductilidade dos mesmos, como se viu no comportamento dos pilares quando as medidas de deformações foram feitas nas barras longitudinais e nas faces dos mesmos.

\subsubsection{5 - Curvas Representativas dos Resultados}

Na seqüência, nas figuras de 4.27 a 4.39, são mostrados os diagramas Força x Deformação, feitos com as leituras dos strain gages colados nas barras longitudinais, nas faces do pilar na direção longitudinal, em um estribo, nas faces do pilar na direção transversal, e dos transdutores de deslocamento fixados verticalmente nas laterais.

Através desses diagramas pode ser notado, já na séries P1a15, P1a10 e P1a05, que com o aumento da taxa de armadura transversal, há aumento nas deformações tanto do pilar quanto dos estribos. Nas séries P2a15, P2a10, o aumento das deformações não foi significativo, mas na série P2a05 houve aumento das deformações em relação à série $\mathrm{P} 1 \mathrm{a} 05$.

Observe-se que as deformações ocorridas nos pilares das séries P3a15, P3a10 e P3a05 foram maiores, e nestas séries a quantidade de fibras adicionadas ao concreto foi a maior usada na pesquisa. Percebe-se que as barras das armaduras, tanto longitudinal quanto transversal atingem o escoamento, havendo portanto bom uso do material.

$\mathrm{Na}$ série P4a15 as deformações permaneceram no mesmo patamar que das séries onde o espaçamento entre estribos era de $15 \mathrm{~cm}$, a menos da série P3a15, mas as séries $\mathrm{P} 4 \mathrm{a} 10$ e P4a05 tiveram deformações maiores, tanto dos pilares, quanto dos materiais, onde o aço atingiu o patamar de escoamento das barras longitudinais e dos estribos. Ficou evidenciado pelos diagramas que aumentando a ductilidade do concreto com a adição de fibras, há um aumento significativo nas deformações conjuntas dos materiais, aço-concreto. Note-se que com o aumento da quantidade de fibras, a deformação nas barras longitudinais chegou ao escoamento, assim como a deformação nos estribos, evidenciando melhor aderência aço-concreto. 


\section{Série P1a15}
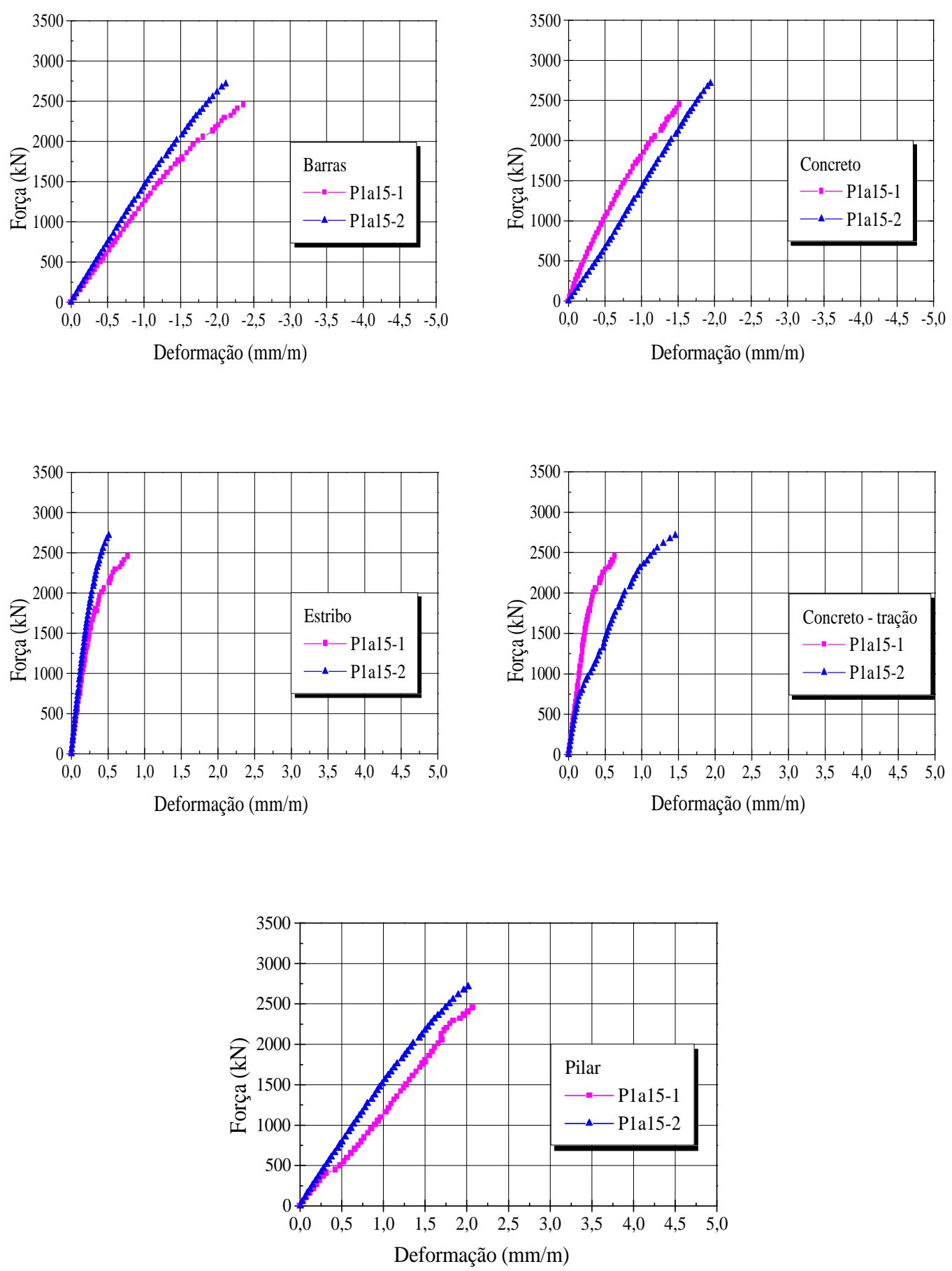

FIGURA 4.27 - Diagramas Força x Deformação da série P1a15 


\section{Série P1a10}
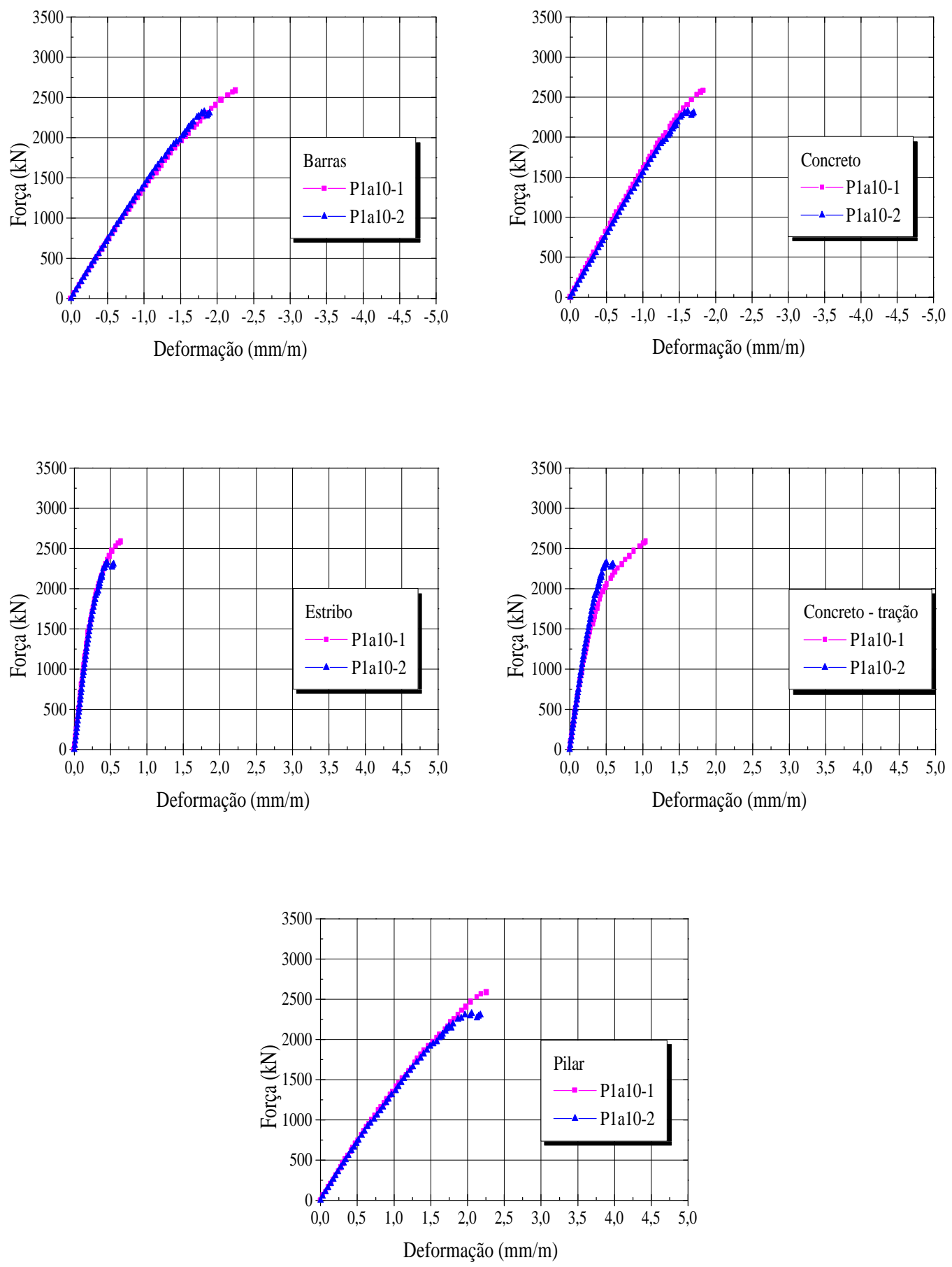

FIGURA 4.28 - Diagramas Força x Deformação da série P1a10 


\section{Série P1a05}
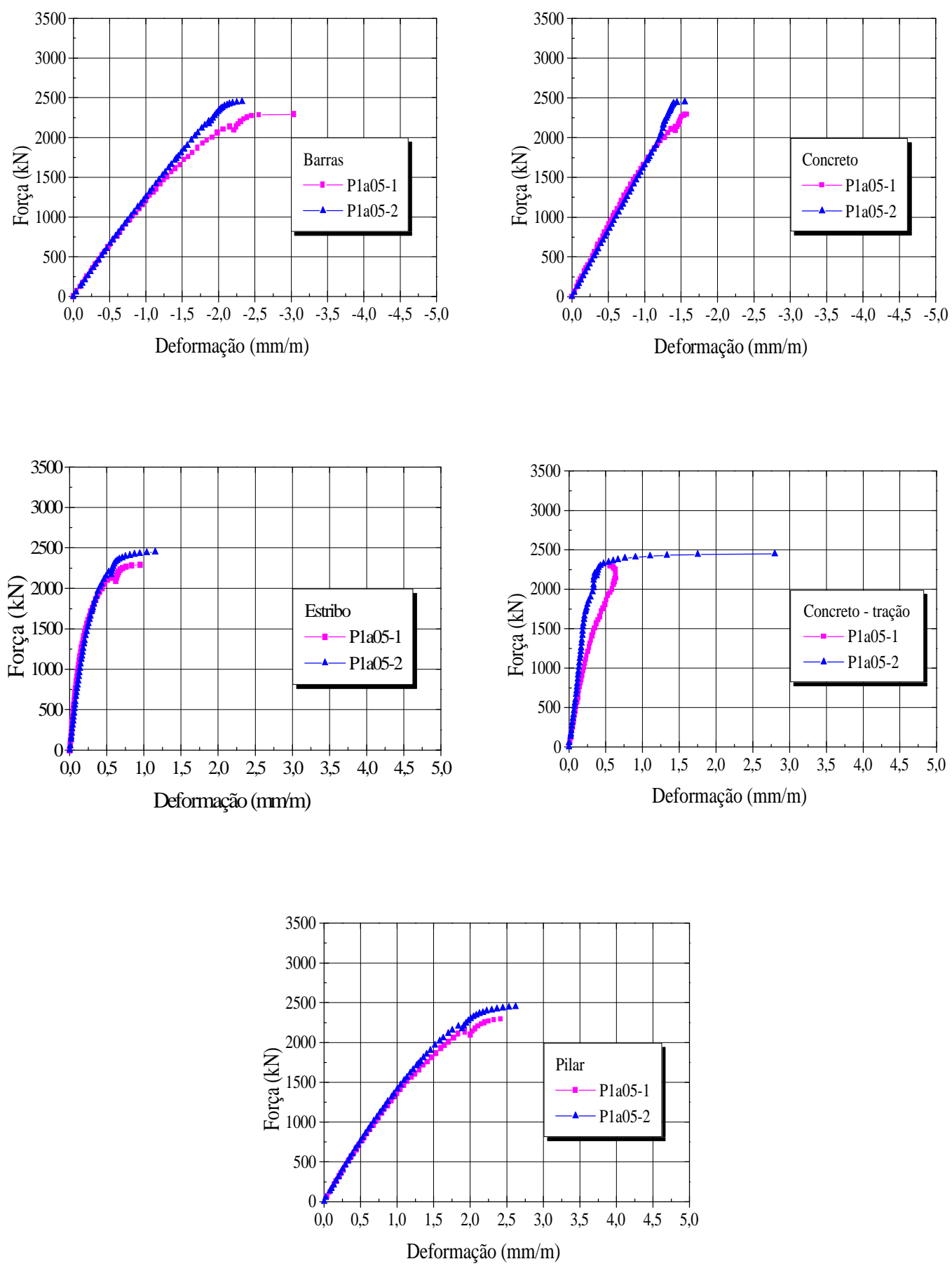

FIGURA 4.29 - Diagramas Força x Deformação da série P1a05 
Série P2a15 e P2a15-r
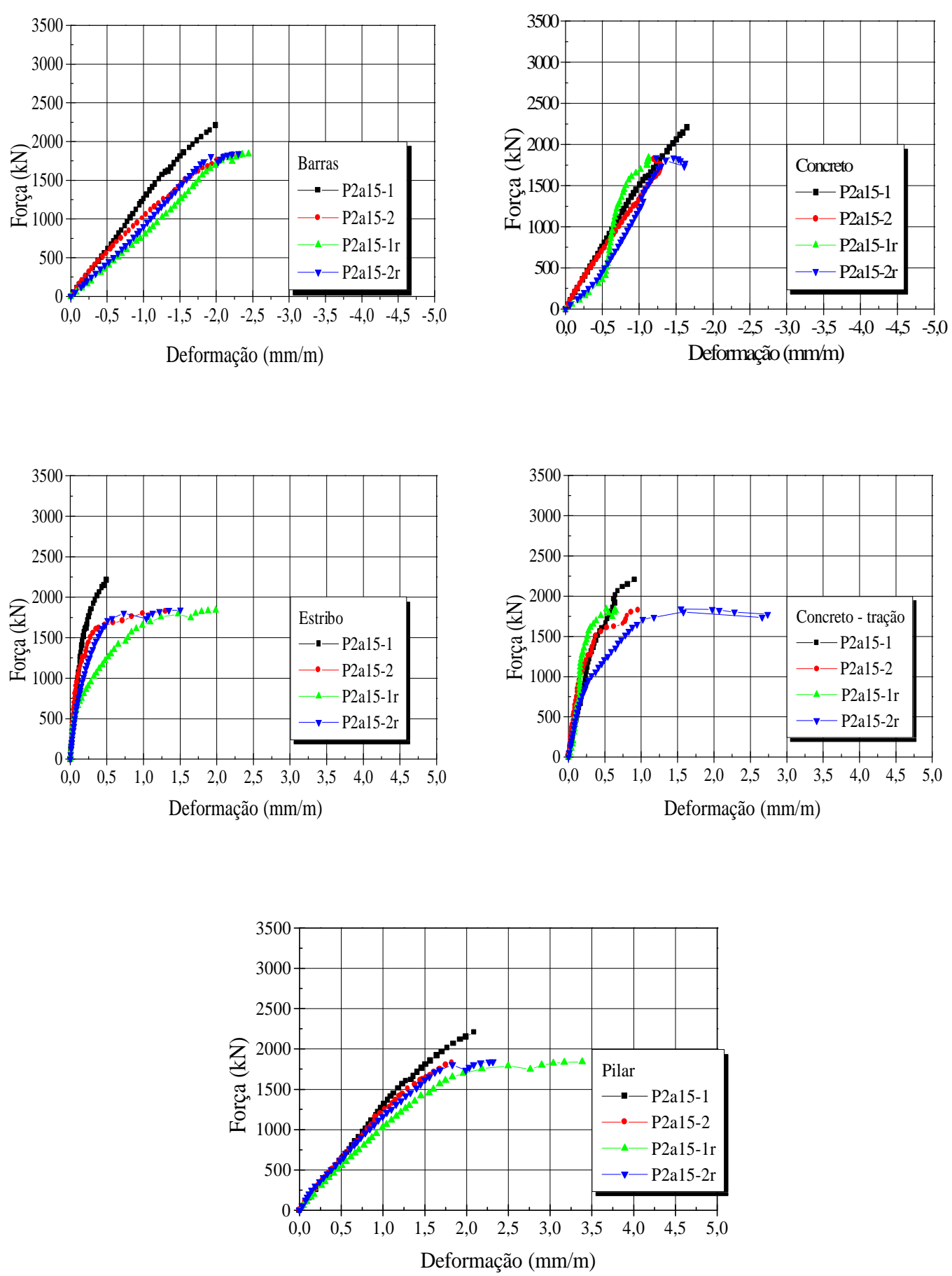

FIGURA 4.30 - Diagramas Força x Deformação da série P2a15 


\section{Série P2a10}
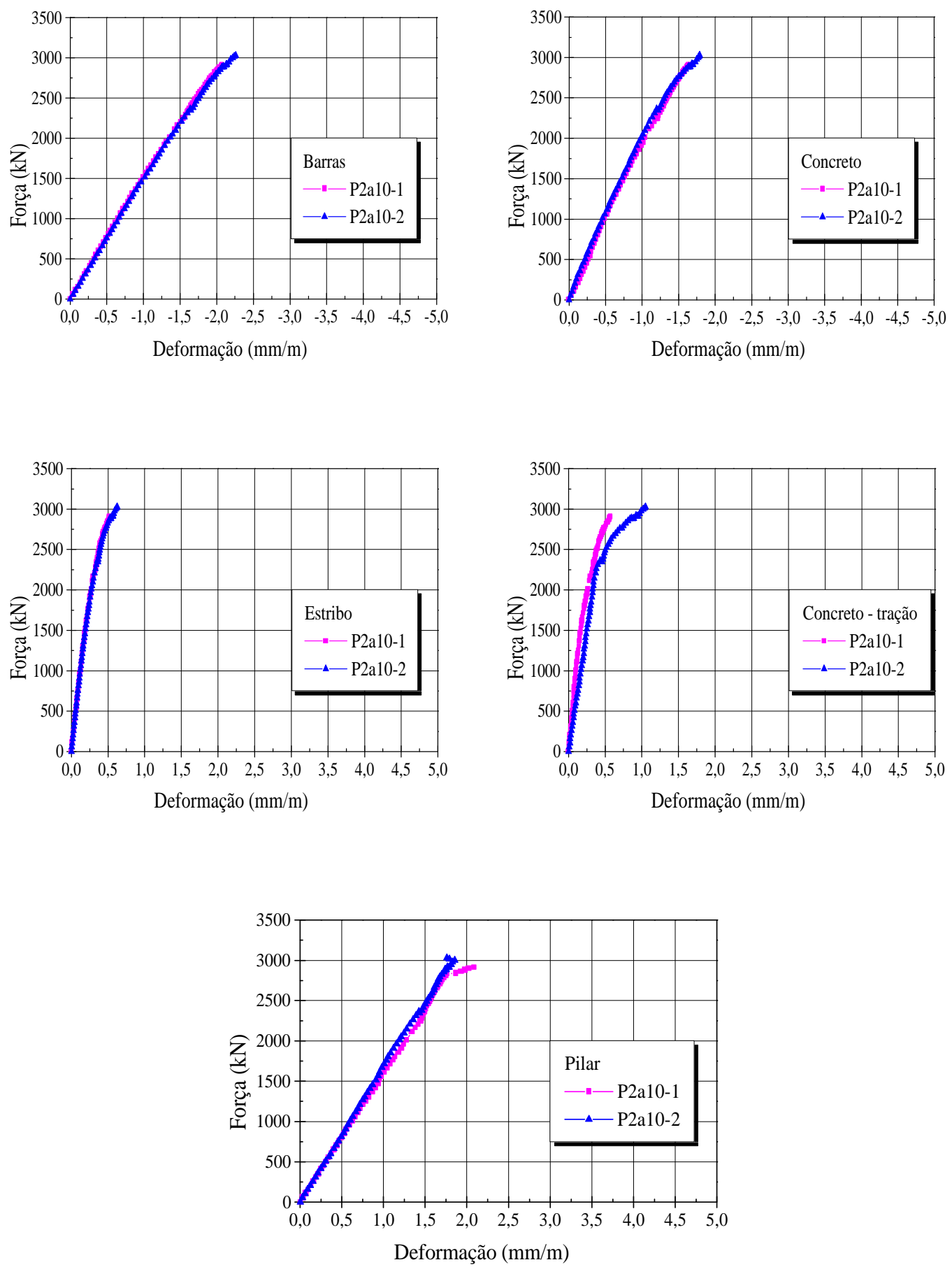

FIGURA 4.31 - Diagramas Força x Deformação da série P2a10 


\section{Série P2a05}
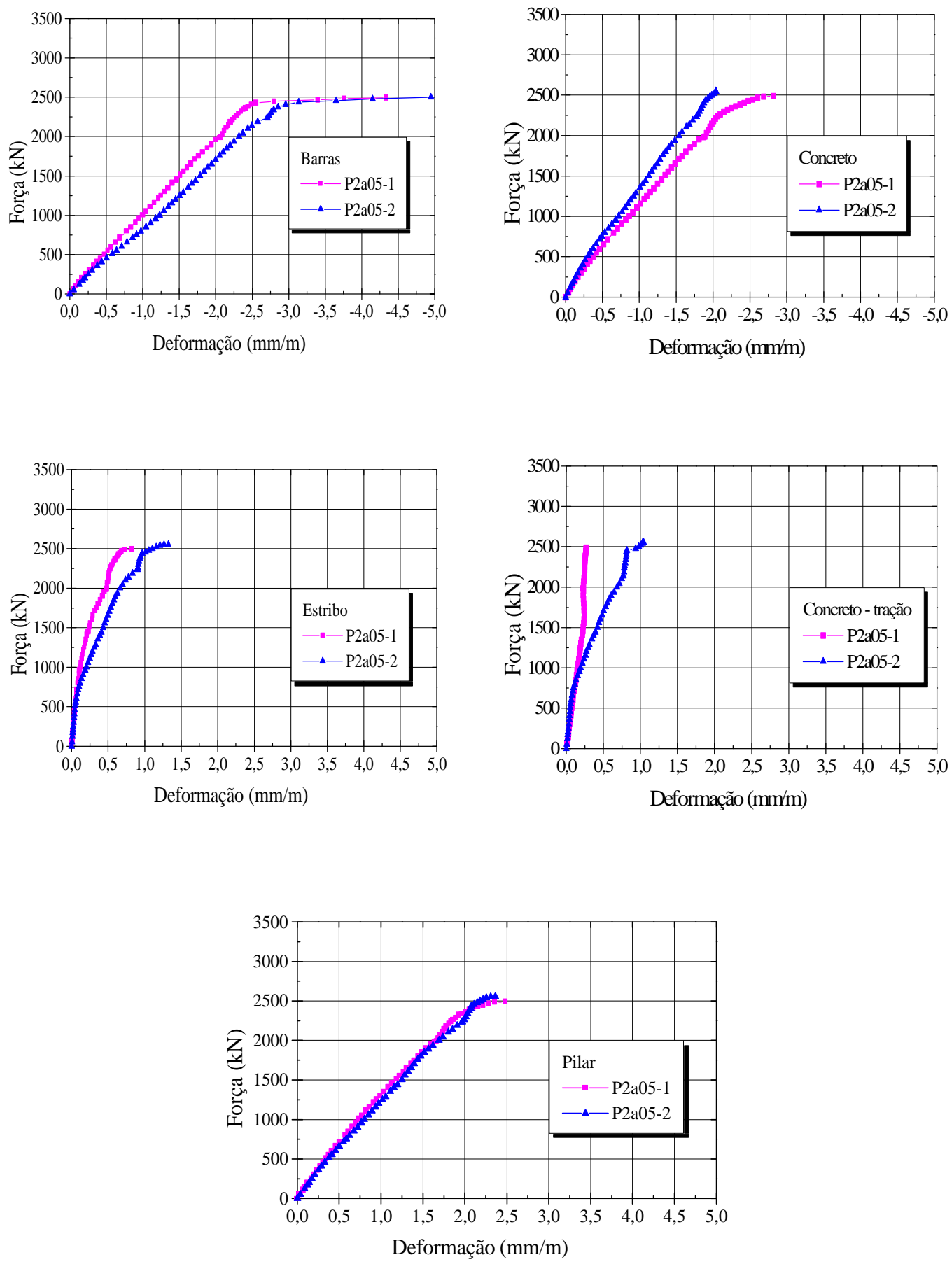

FIGURA 4.32 - Diagramas Força x Deformação da série P2a05 


\section{Série P3a15}
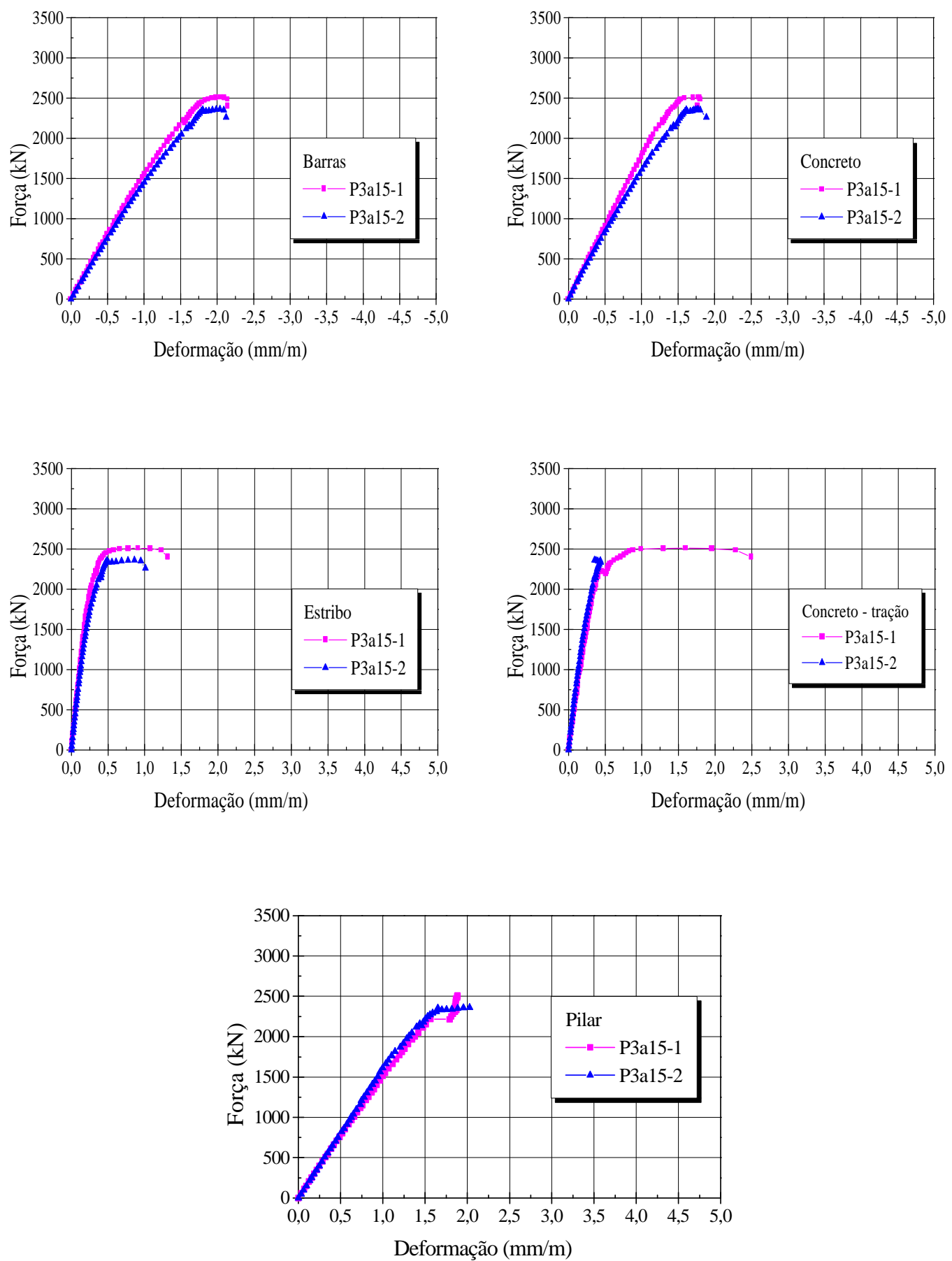

FIGURA 4.33 - Diagramas Força x Deformação da série P3a15 


\section{Série P3a10}
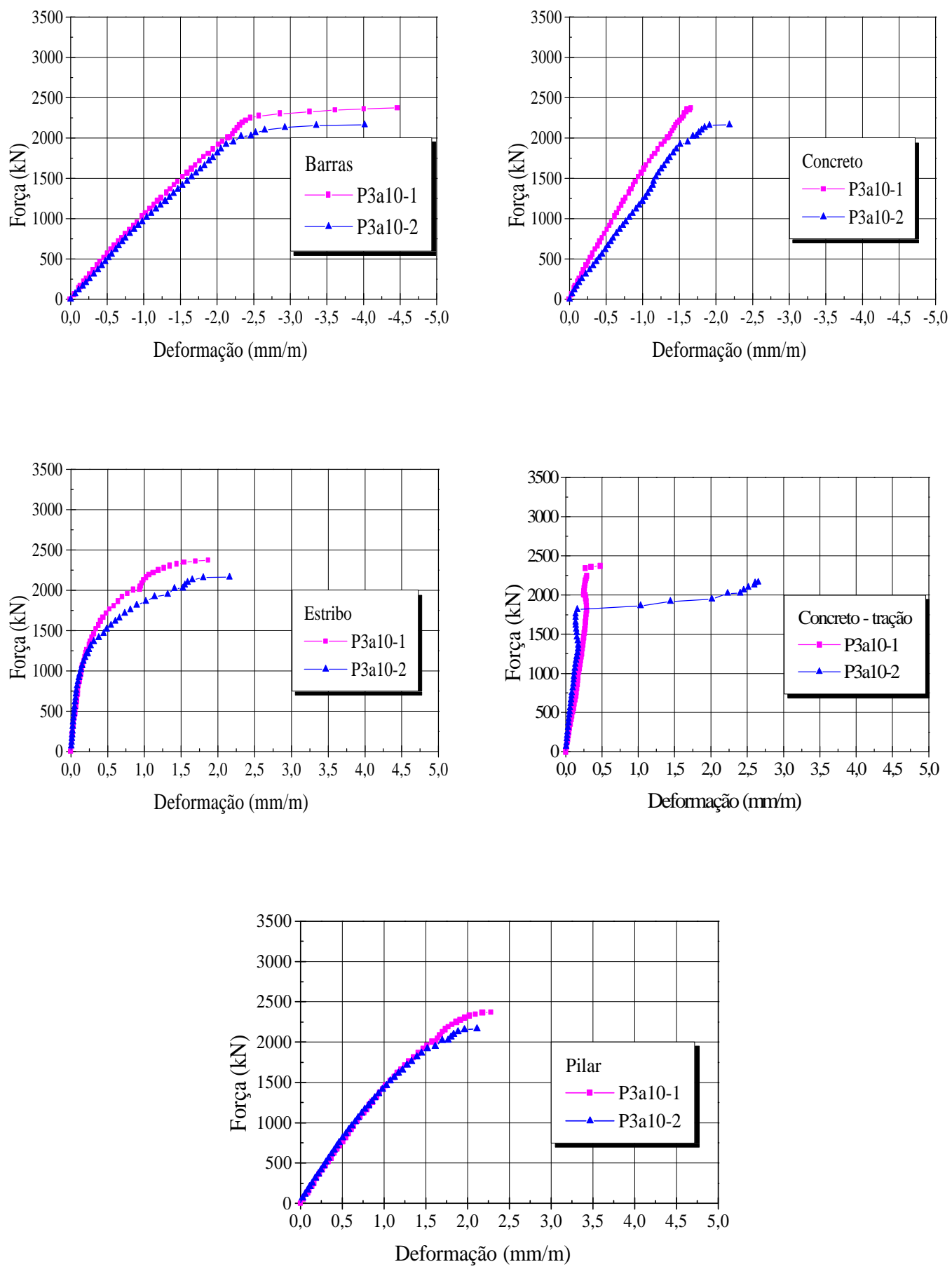

FIGURA 4.34 - Diagramas Força x Deformação da série P3a10 


\section{Série P3a05}
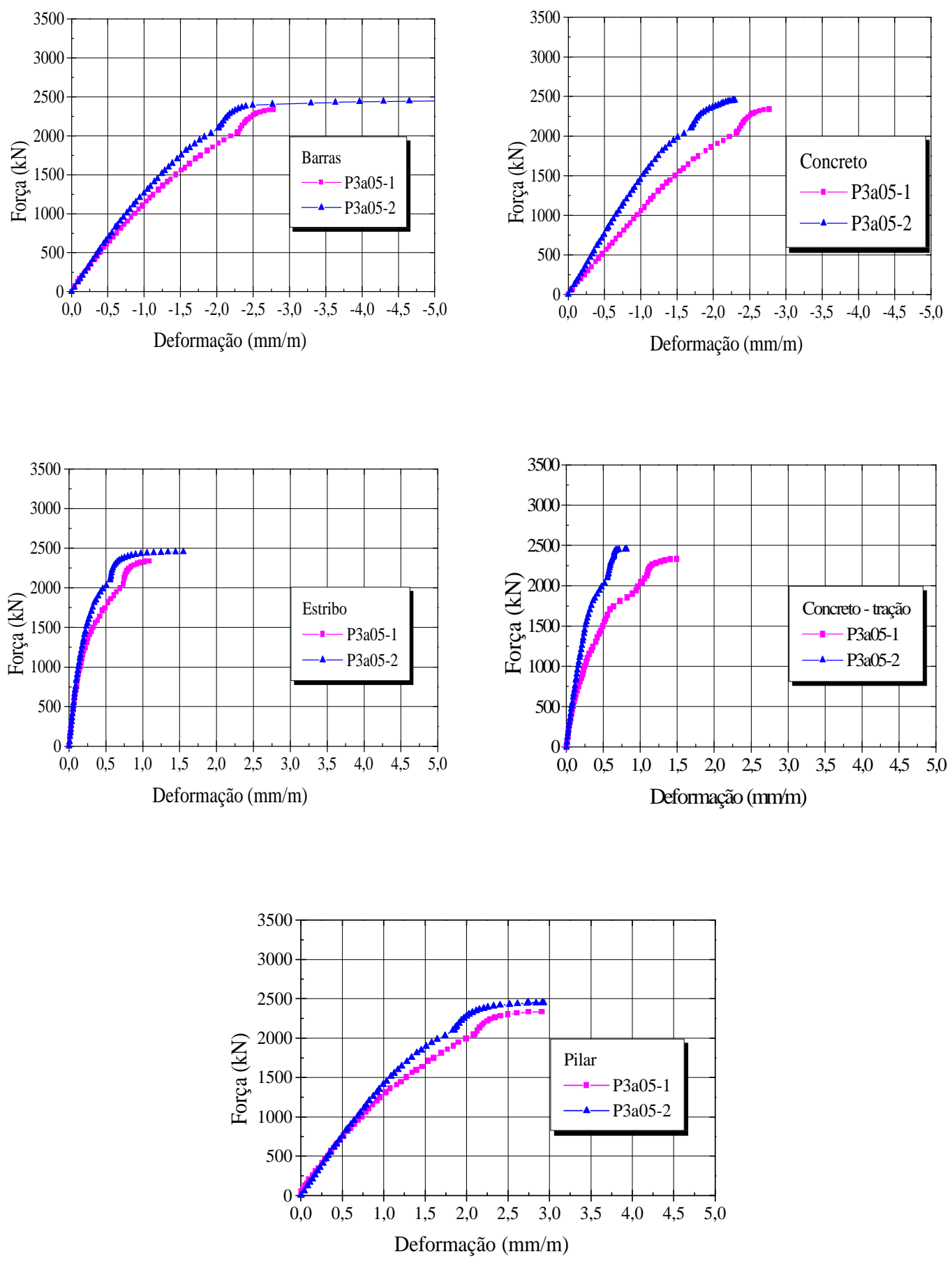

FIGURA 4.35 - Diagramas Força x Deformação da série P3a05 


\section{Série P4a15}
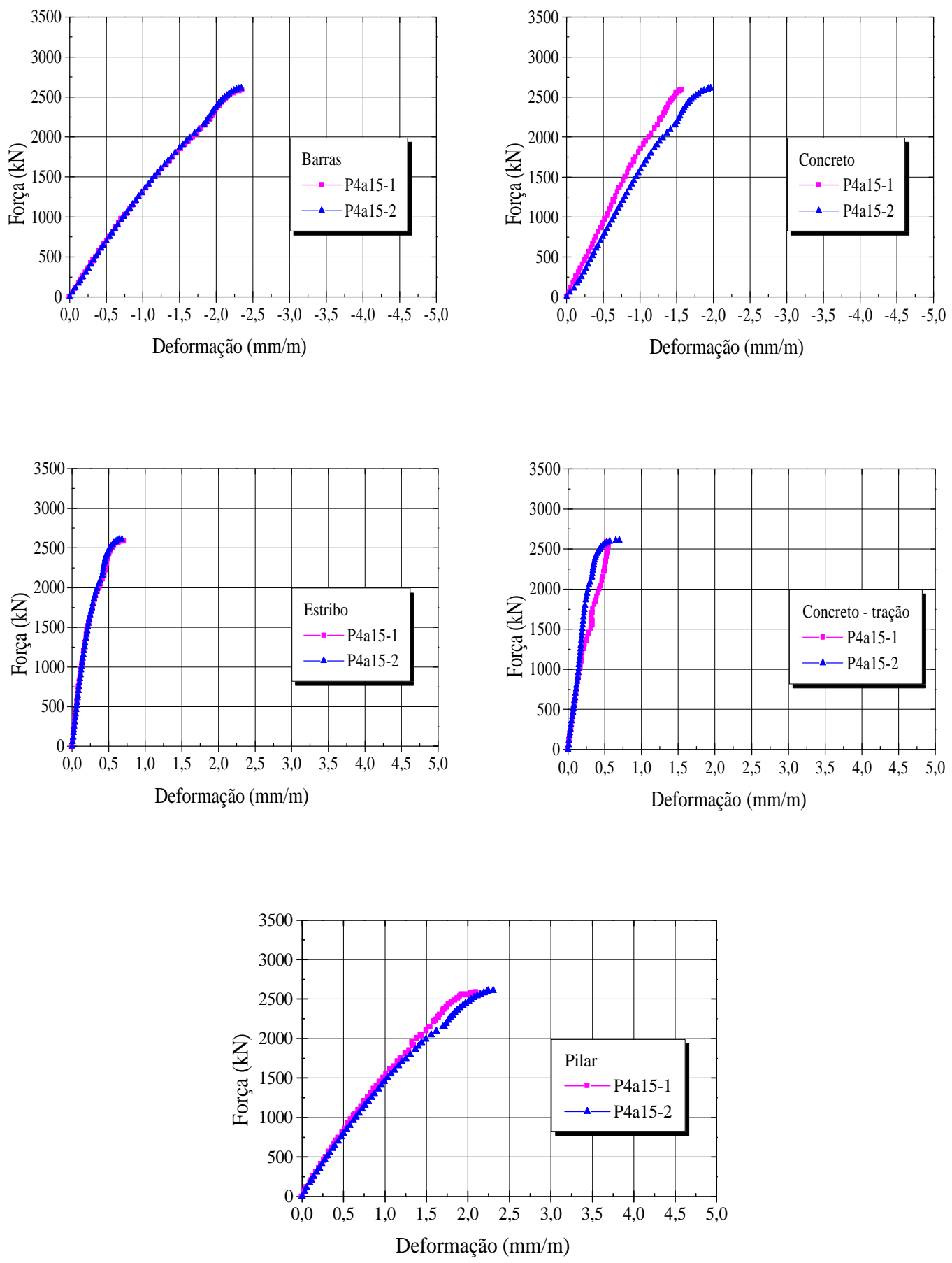

FIGURA 4.36 - Diagramas Força x Deformação da série P4a15 


\section{Série P4a10}
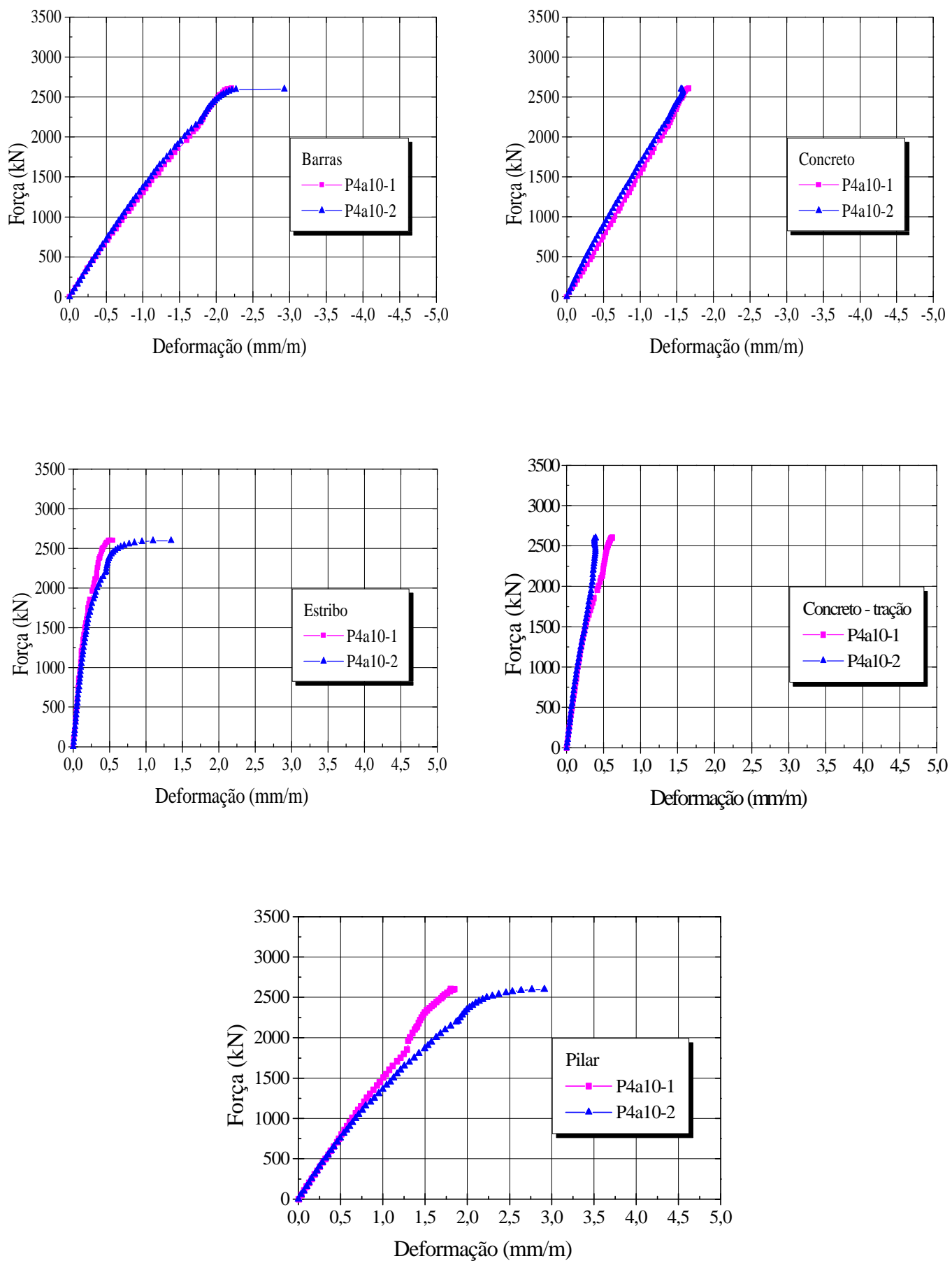

FIGURA 4.37 - Diagramas Força x Deformação da série P4a10 


\section{Série P4a05}
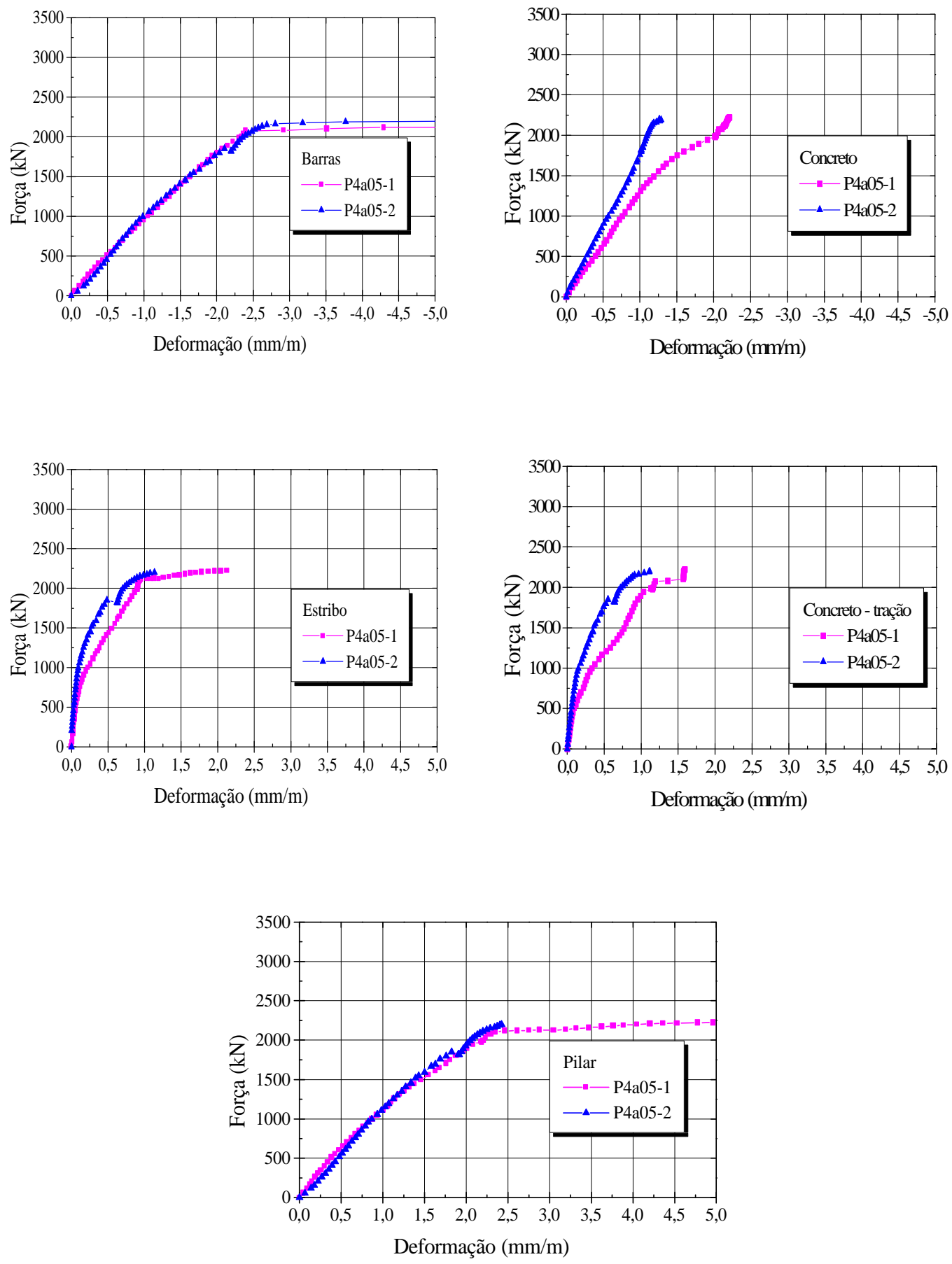

FIGURA 4.38 - Diagramas Força x Deformação da série P4a05 


\section{Série P3p10}
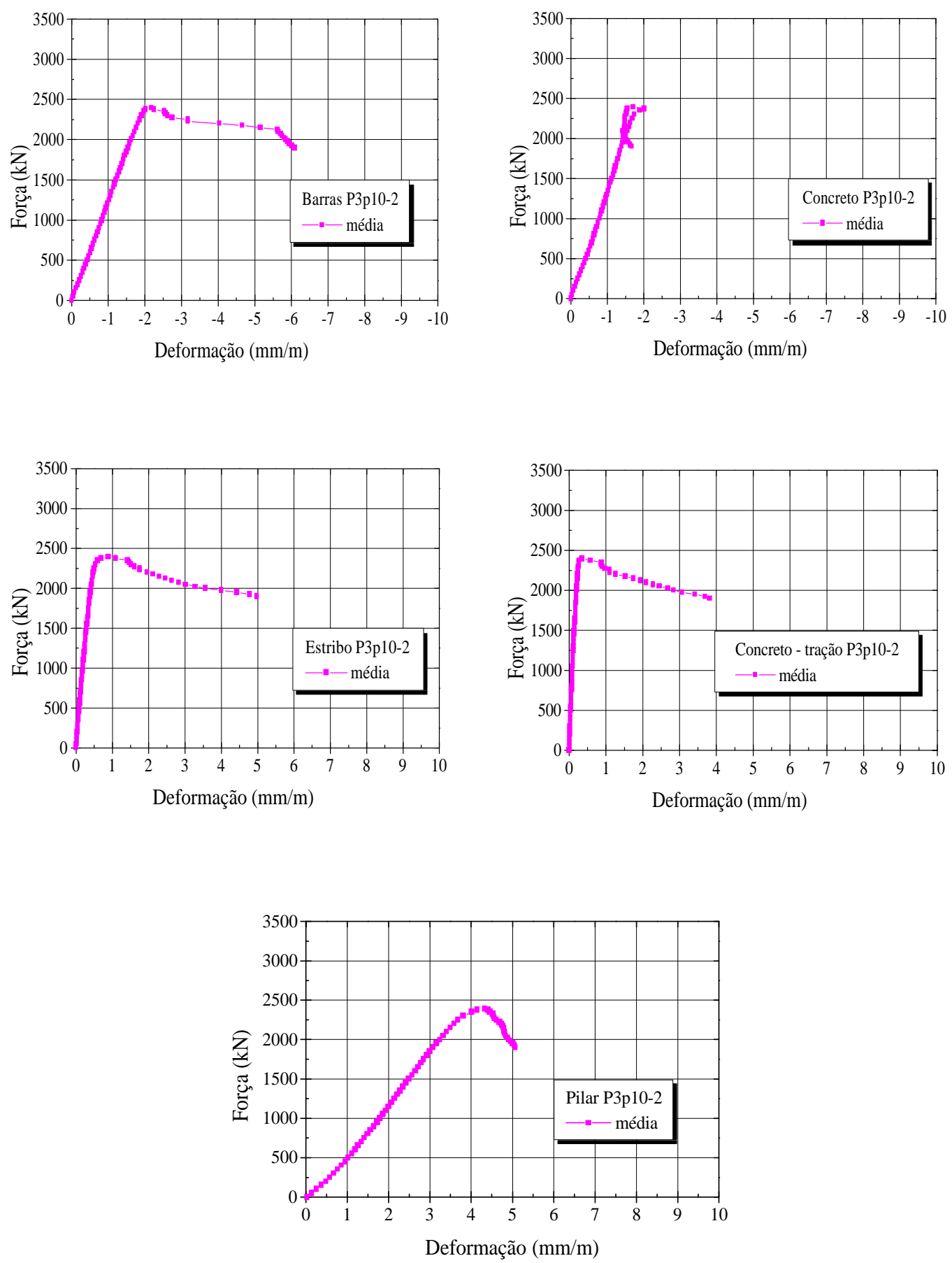

FIGURA 4.39 - Diagramas Força x Deformação da série P3p10 


\section{4 - CONSIDERAÇÕES FINAIS}

No próximo capítulo, faz-se uma análise deste resultados experimentais, comparando-os com os resultados obtidos via análise numérica, utilizando um programa de métodos numéricos baseado no método dos elementos finitos.

Além desta análise, mostram-se também análise dos resultados experimentais e teóricos determinados segundo as indicações de outros pesquisadores. 


\section{ANÁLISE DOS RESULTADOS}

\section{1 - CONSIDERAÇÕES INICIAIS}

Neste capítulo se apresentam as análises dos resultados obtidos experimentalmente, dos resultados obtidos com análise numérica, feita com uso do programa ANSYS(1997), que utiliza o método dos elementos finitos para modelagem dos pilares e mostram-se também os resultados experimentais obtidos por LIMA(1997), em ensaios de pilares de concreto de alta resistência sem adição de fibras, submetidos à compressão centrada.

\section{2 - ANÁLISE DOS RESULTADOS EXPERIMENTAIS}

A tabela 5.1 mostra os resultados obtidos experimentalmente, os resultados obtidos através de uma análise teórica, e a relação existente entre eles, onde $F_{u \text {,exp }}$ é a força última experimental, $F_{u n \text {,teo }}$ a força calculada considerando a seção transversal

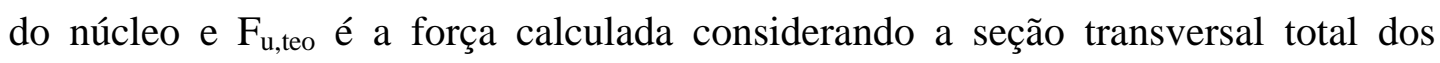
pilares.

$\mathrm{O}$ fato da relação $\mathrm{F}_{\mathrm{u}, \text { exp }} / \mathrm{F}_{\mathrm{un} \text {,teo }}$ ser bem mais próxima de 1,00 do que a relação $\mathrm{F}_{\mathrm{u}, \exp } / \mathrm{F}_{\mathrm{u} \text {,teo }}$, indica que a seção resistente do pilar é formada pelo núcleo da seção transversal, como mostrado por outros pesquisadores, em experiências com 
pilares de CAD. Nesta pesquisa também ficou evidenciado que a resistência última do pilar é definida pelo núcleo delimitado pelos estribos, quando se adicionam fibras ao CAD.

Tabela 5.1 - Análise Teórica dos Resultados dos Ensaios

\begin{tabular}{|c|c|c|c|c|c|c|c|c|}
\hline Pilar & $\begin{array}{c}\mathbf{V}_{\mathbf{f}} \\
(\%)\end{array}$ & $\begin{array}{c}\rho_{\mathrm{w}} \\
(\%)\end{array}$ & 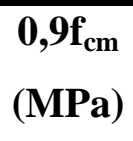 & $\begin{array}{c}\mathbf{F}_{\mathrm{u}, \exp } \\
(\mathrm{kN})\end{array}$ & $\begin{array}{l}\mathbf{F}_{\mathrm{u}, \text { teo }} \\
(\mathbf{k N})\end{array}$ & $\begin{array}{c}\mathbf{F}_{\mathbf{u}, \exp } \\
/ \mathbf{F}_{\mathbf{u}, \text { teo }}\end{array}$ & $\begin{array}{c}F_{\text {un,teo }} \\
(\mathbf{k N})\end{array}$ & $\begin{array}{c}\mathbf{F}_{\mathbf{u}, \mathbf{e x p}} \\
/ \mathbf{F}_{\text {un,teo }}\end{array}$ \\
\hline P1a15-1 & 0,25 & 0,55 & 72,93 & 2.453 & 3.383 & 0,73 & 2.303 & 1,07 \\
\hline P1a15-2 & 0,25 & 0,55 & 79,03 & 2.714 & 3.621 & 0,75 & 2.451 & 1,11 \\
\hline P1a10-1 & 0,25 & 0,82 & 76,92 & 2.581 & 3.539 & 0,73 & 2.400 & 1,08 \\
\hline P1a10-2 & 0,25 & 0,82 & 76,92 & 2.304 & 3.539 & 0,65 & 2.400 & 0,96 \\
\hline P1a05-1 & 0,25 & 1,63 & 72,61 & 2.291 & 3.371 & 0,68 & 2.295 & 1,00 \\
\hline P1a05-2 & 0,25 & 1,63 & 72,61 & 2.449 & 3.371 & 0,73 & 2.295 & 1,07 \\
\hline P2a15-1 & 0,50 & 0,55 & 64,67 & 2.208 & 3.061 & 0,72 & 2.103 & 1,05 \\
\hline $\mathrm{P} 2 \mathrm{a} 15-2$ & 0,50 & 0,55 & 64,67 & 1.827 & 3.061 & 0,60 & 2.103 & 0,87 \\
\hline P2a15-1r & 0,50 & 0,55 & 59,82 & 1.840 & 2.871 & 0,64 & 1.985 & 0,93 \\
\hline $\mathrm{P} 2 \mathrm{a} 15-2 \mathrm{r}$ & 0,50 & 0,55 & 59,82 & 1.841 & 2.871 & 0,64 & 1.985 & 0,93 \\
\hline P2a10-1 & 0,50 & 0,82 & 71,98 & 2.911 & 3.346 & 0,87 & 2.280 & 1,28 \\
\hline P2a10-2 & 0,50 & 0,82 & 71,98 & 3.028 & 3.346 & 0,91 & 2.280 & 1,33 \\
\hline $\mathrm{P} 2 \mathrm{a} 05-1$ & 0,50 & 1,63 & 69,87 & 2.491 & 3.264 & 0,76 & 2.229 & 1,12 \\
\hline $\mathrm{P} 2 \mathrm{a} 05-2$ & 0,50 & 1,63 & 69,87 & 2.554 & 3.264 & 0,78 & 2.229 & 1,15 \\
\hline P3a15-1 & 1,00 & 0,55 & 69,37 & 2.509 & 3.244 & 0,77 & 2.217 & 1,13 \\
\hline P3a15-2 & 1,00 & 0,55 & 69,37 & 2.360 & 3.244 & 0,73 & 2.217 & 1,06 \\
\hline P3a10-1 & 1,00 & 0,82 & 58,52 & 2.373 & 2.821 & 0,84 & 1.954 & 1,21 \\
\hline P3a10-2 & 1,00 & 0,82 & 58,52 & 2.164 & 2.821 & 0,77 & 1.954 & 1,11 \\
\hline P3a05-1 & 1,00 & 1,63 & 62,14 & 2.333 & 2.962 & 0,79 & 2.041 & 1,14 \\
\hline P3a05-2 & 1,00 & 1,63 & 62,14 & 2.454 & 2.962 & 0,83 & 2.041 & 1,20 \\
\hline P4a15-1 & 0,75 & 0,55 & 71,88 & 2.584 & 3.342 & 0,77 & 2.277 & 1,14 \\
\hline $\mathrm{P} 4 \mathrm{a} 15-2$ & 0,75 & 0,55 & 71,88 & 2.609 & 3.342 & 0,78 & 2.277 & 1,15 \\
\hline P4a10-1 & 0,75 & 0,82 & 77,72 & 2.603 & 3.573 & 0,73 & 2.421 & 1,08 \\
\hline P4a10-2 & 0,75 & 0,82 & 77,72 & 2.598 & 3.573 & 0,73 & 2.421 & 1,07 \\
\hline $\mathrm{P} 4 \mathrm{a} 05-1$ & 0,75 & 1,63 & 67,69 & 2.222 & 3.190 & 0,70 & 2.183 & 1,02 \\
\hline $\mathrm{P} 4 \mathrm{a} 05-2$ & 0,75 & 1,63 & 67,69 & 2.199 & 3.190 & 0,69 & 2.183 & 1,01 \\
\hline P3p10-2 & 0,50 & 0,82 & 51,35 & 2.391 & 2.541 & 0,94 & 1.780 & 1,34 \\
\hline
\end{tabular}


Para o cálculo da força resistente foi usada a equação 4.1, descrita no capítulo 4, considerando apenas a seção transversal do núcleo dos pilares.

Para o cálculo da força resistente considerando a seção transversal total, usou-se a expressão 5.1.

$F_{u, t e o}=\left(A_{c}-A_{s}\right) f_{c}+A_{s} f_{y}$

onde:

$\mathrm{A}_{\mathrm{c}} \quad=$ área da seção transversal total do pilar.

COLLINS et al.(1993) propõe um coeficiente $\mathrm{K}_{3}$, multiplicando a parcela resistente do concreto, para se levar em conta a seção transversal total do pilar, sendo a fórmula descrita da seguinte maneira:

$$
F_{u, t e o}=K_{3}\left(A_{c}-A_{s}\right) f_{c}+A_{s} f_{y}
$$

onde:

$$
K_{3}=0,6+\frac{10}{f_{c}^{\prime}} \text { para } \mathrm{f}_{\mathrm{c}}^{\prime} \text { em MPa. }
$$

Na tabela 5.2 pode ser vista uma análise entre os valores obtidos para a força resistente teórica, utilizando o coeficiente $\mathrm{K}_{3}$ proposto por COLLINS et al.(1993), com os resultados experimentais.

A formulação indicada por COLLINS et al.(1993) é baseada na determinação da resistência à compressão do concreto através de ensaios de corpos-de-prova cilíndricos de $15 \mathrm{~cm}$ x $30 \mathrm{~cm}$. Como nos ensaios realizados para determinação da resistência média à compressão $\mathrm{f}_{\mathrm{cm}}$ usaram-se corpos-de-prova de $10 \mathrm{~cm}$ x $20 \mathrm{~cm}$, fazse um ajuste em $\mathrm{f}_{\mathrm{cm}}$ multiplicando-o com o coeficiente 0,95 , que é para se levar em consideração a diferença das dimensões dos corpos-de-prova.

Pode-se perceber pelos resultados que a indicação de COLLINS et al.(1993) levou a valores contra a segurança, quando comparado com os resultados experimentais obtidos nesta pesquisa.

A adição de fibras ao concreto diminui sua resistência à compressão, mas como as taxas de fibras usadas para execução do concreto dos pilares ficaram nos limites inferiores indicadas pela literatura técnica, não houve diferenciação de uma resistência ou outra, em função da adição de fibras, sendo necessário um número 
maior de ensaios para a indicação de outro coeficiente no lugar de $\mathrm{K}_{3}$ para o cálculo da força resistente, considerando a seção transversal total e para que fosse levada em conta a adição de fibras ao concreto

Tabela 5.2 - Análise Teórica Segundo COLLINS et al.(1993)

\begin{tabular}{|c|c|c|c|c|c|c|}
\hline Pilar & $\begin{array}{c}\mathbf{V}_{\mathbf{f}} \\
(\%)\end{array}$ & $\begin{array}{r}\mathbf{0 , 9 5 f _ { c m }} \\
(\mathbf{M P a})\end{array}$ & $\mathbf{K}_{\mathbf{3}}$ & $\begin{array}{r}\mathbf{F}_{\mathbf{u}, \exp } \\
(\mathbf{k N})\end{array}$ & $\begin{array}{c}\mathbf{F}_{\mathbf{u}, \text { teo }} \\
(\mathbf{k N})\end{array}$ & $\begin{array}{c}\mathbf{F}_{\mathbf{u}, \exp } \\
/ \mathbf{F}_{\mathbf{u}, \text { teo }}\end{array}$ \\
\hline P1a15-1 & 0,25 & 76,98 & 0,730 & 2.453 & 2.730 & 0,90 \\
\hline P1a15-2 & 0,25 & 83,42 & 0,720 & 2.714 & 2.881 & 0,94 \\
\hline P1a10-1 & 0,25 & 81,20 & 0,723 & 2.581 & 2.828 & 0,91 \\
\hline P1a10-2 & 0,25 & 81,20 & 0,723 & 2.304 & 2.828 & 0,82 \\
\hline $\mathrm{P} 1 \mathrm{a} 05-1$ & 0,25 & 76,65 & 0,730 & 2.291 & 2.720 & 0,84 \\
\hline $\mathrm{P} 1 \mathrm{a} 05-2$ & 0,25 & 76,65 & 0,730 & 2.449 & 2.720 & 0,90 \\
\hline P2a15-1 & 0,50 & 68,26 & 0,747 & 2.208 & 2.527 & 0,87 \\
\hline $\mathrm{P} 2 \mathrm{a} 15-2$ & 0,50 & 68,26 & 0,747 & 1.827 & 2.527 & 0,72 \\
\hline $\mathrm{P} 2 \mathrm{a} 15-1 \mathrm{r}$ & 0,50 & 63,14 & 0,758 & 1.840 & 2.405 & 0,77 \\
\hline P2a15-2r & 0,50 & 63,14 & 0,758 & 1.841 & 2.405 & 0,77 \\
\hline P2a10-1 & 0,50 & 75,98 & 0,732 & 2.911 & 2.707 & 1,08 \\
\hline P2a10-2 & 0,50 & 75,98 & 0,732 & 3.028 & 2.707 & 1,12 \\
\hline $\mathrm{P} 2 \mathrm{a} 05-1$ & 0,50 & 73,75 & 0,736 & 2.491 & 2.655 & 0,94 \\
\hline $\mathrm{P} 2 \mathrm{a} 05-2$ & 0,50 & 73,75 & 0,736 & 2.554 & 2.655 & 0,96 \\
\hline P3a15-1 & 1,00 & 73,23 & 0,737 & 2.509 & 2.643 & 0,95 \\
\hline P3a15-2 & 1,00 & 73,23 & 0,737 & 2.360 & 2.643 & 0,89 \\
\hline P3a10-1 & 1,00 & 61,77 & 0,762 & 2.373 & 2.374 & 1,00 \\
\hline P3a10-2 & 1,00 & 61,77 & 0,762 & 2.164 & 2.374 & 0,91 \\
\hline P3a05-1 & 1,00 & 65,59 & 0,753 & 2.333 & 2.464 & 0,95 \\
\hline $\mathrm{P} 3 \mathrm{a} 05-2$ & 1,00 & 65,59 & 0,753 & 2.454 & 2.464 & 1,00 \\
\hline P4a15-1 & 0,75 & 75,88 & 0,732 & 2.584 & 2.704 & 0,96 \\
\hline P4a15-2 & 0,75 & 75,88 & 0,732 & 2.609 & 2.704 & 0,97 \\
\hline P4a10-1 & 0,75 & 82,13 & 0,722 & 2.603 & 2.851 & 0,91 \\
\hline P4a10-2 & 0,75 & 82,13 & 0,722 & 2.598 & 2.851 & 0,91 \\
\hline $\mathrm{P} 4 \mathrm{a} 05-1$ & 0,75 & 71,76 & 0,739 & 2.222 & 2.606 & 0,85 \\
\hline $\mathrm{P} 4 \mathrm{a} 05-2$ & 0,75 & 71,76 & 0,739 & 2.199 & 2.606 & 0,84 \\
\hline P3p10-2 & 0,50 & 54,21 & 0,785 & 2.391 & 2.197 & 1,09 \\
\hline
\end{tabular}




\section{3 - ANÂLISE DOS RESULTADOS EXPERIMENTAIS E DOS NUMÊRICAMENTE OBTIDOS}

\subsection{1 - MODELAGEM DOS PILARES}

Foi utilizado o programa ANSYS(1997), que considera o método dos elementos finitos, para fazer uma análise numérica do comportamento Força $\mathrm{x}$ Deformação dos pilares.

Adotou-se um elemento finito sólido para representar o concreto, o solid45, e um elemento de barra tridimensional representando as barras longitudinais e os estribos, o beam3. As dimensões dos pilares foram as mesmas com a seção transversal de $20 \mathrm{~cm} \times 20 \mathrm{~cm}$ e altura de $120 \mathrm{~cm}$.

A vinculação escolhida para simular os ensaios experimentais foi de se impedir todos os movimentos do elemento em uma das extremidades, ou seja engastando-a, e na outra foi aplicado um deslocamento na direção paralela ao comprimento do pilar e mais um impedimento nos 4 pontos que definem a seção transversal do elemento, para que não houvesse flexão do pilar ao longo do processo numérico de aplicação da ação.

Foi possível dar ao programa os dados experimentais dos materiais, como as curvas Tensão x Deformação dos aços, barras de $12,5 \mathrm{~mm}$ e $6,3 \mathrm{~mm}$ que foram as mesmas para todos os modelos, e do concreto, que variou de modelo para modelo.

Na figura 5.1a, é mostrada a discretização dos modelos de pilares contendo espaçamento entre estribos de $5 \mathrm{~cm}$. A discretização em elementos finitos dos pilares contendo espaçamento de $10 \mathrm{~cm}$ entre estribos pode ser vista na figura $5.1 \mathrm{~b}$. E por último a vista da discretização dos modelos de pilares com espaçamento entre estribos de $15 \mathrm{~cm}$ na figura $5.1 \mathrm{c}$.

Na figura 5.2 pode ser vista a distribuição das tensões de compressão na direção longitudinal (eixo z) do pilar representando a série P1a15. Para as outras séries, a distribuição foi similar na figura citada. 


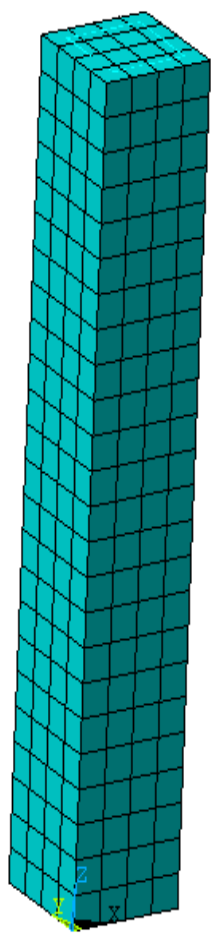

(a)

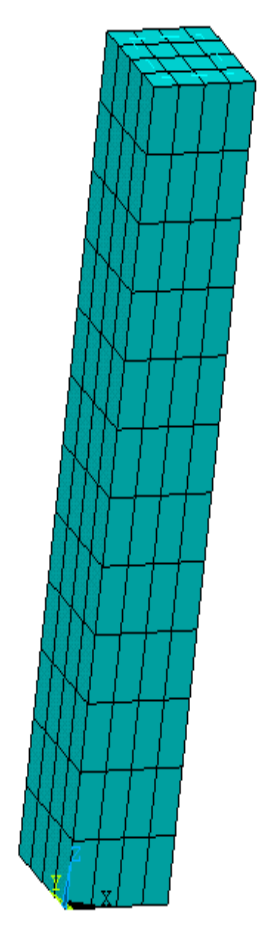

(b)

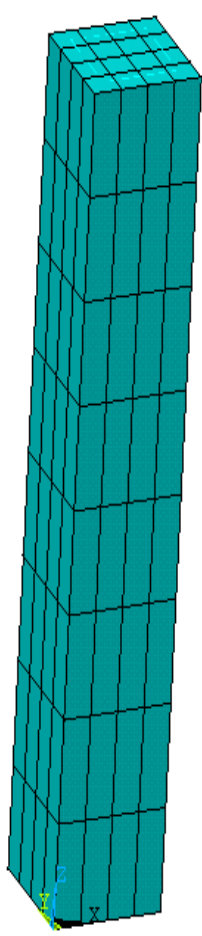

(c)

FIGURA 5.1 - Discretização dos Pilares conforme o Espaçamento entre Estribos
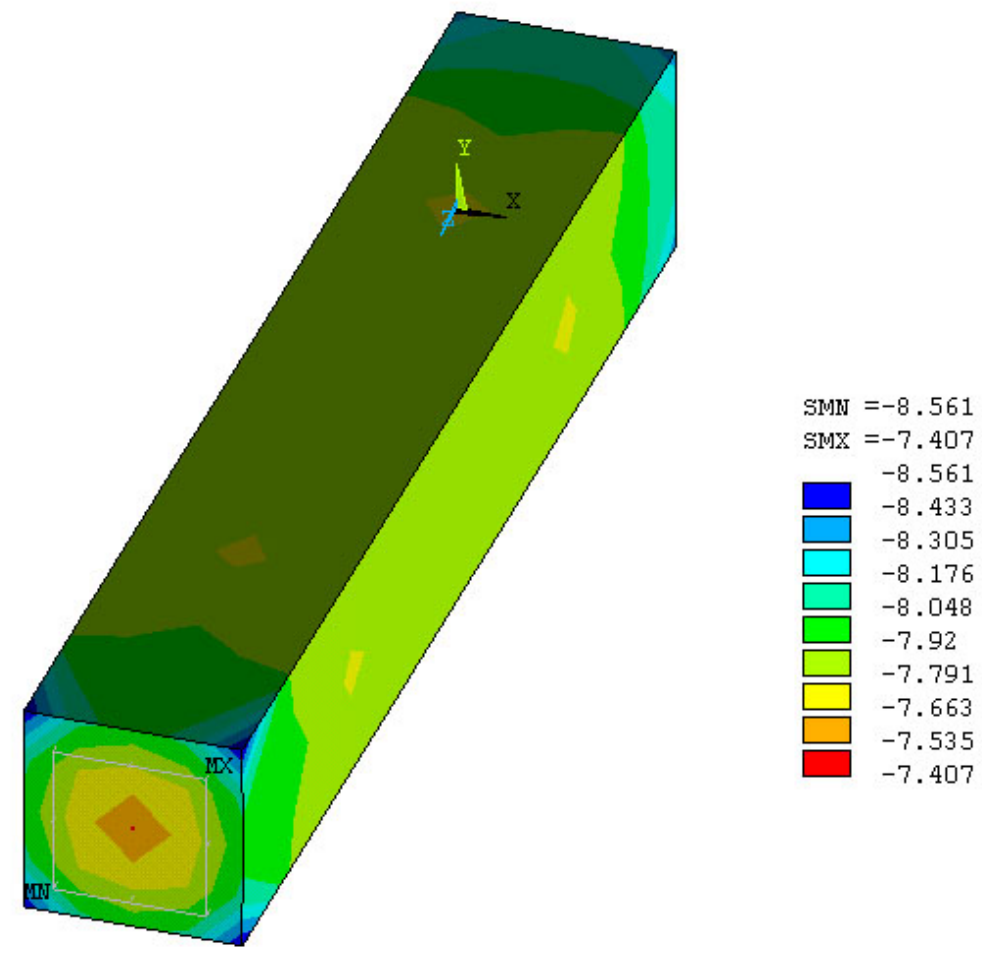

FIGURA 5.2 - Distribuição das Tensões - Ilustração Geral 
Na figura 5.3, mostra-se a composição da armadura, em barras longitudinais e transversais, onde na figura 5.3a os estribos estão espaçados $5 \mathrm{~cm}$ entre si.

A figura 5.3b mostra os arranjos onde os estribos tem espaçamento de $10 \mathrm{~cm} \mathrm{e}$ na figura $5.3 \mathrm{c}$, o espaçamento é de $15 \mathrm{~cm}$ entre os estribos.

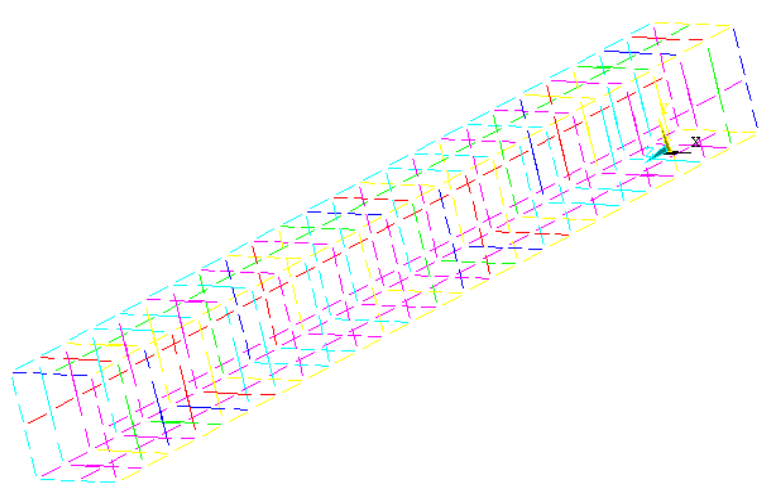

(a)

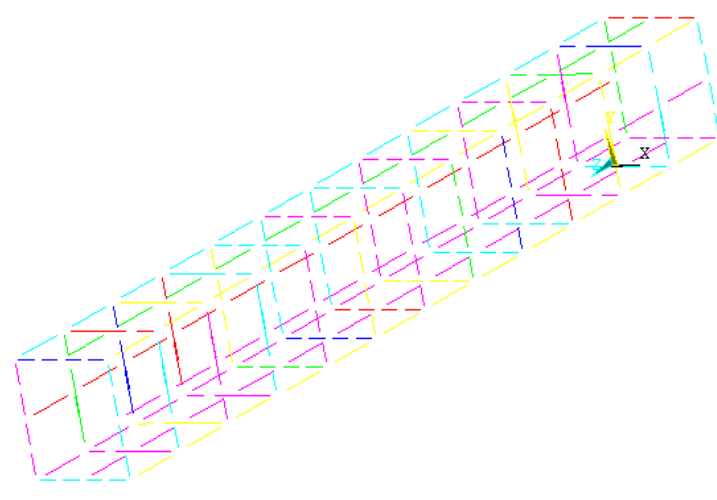

(b)

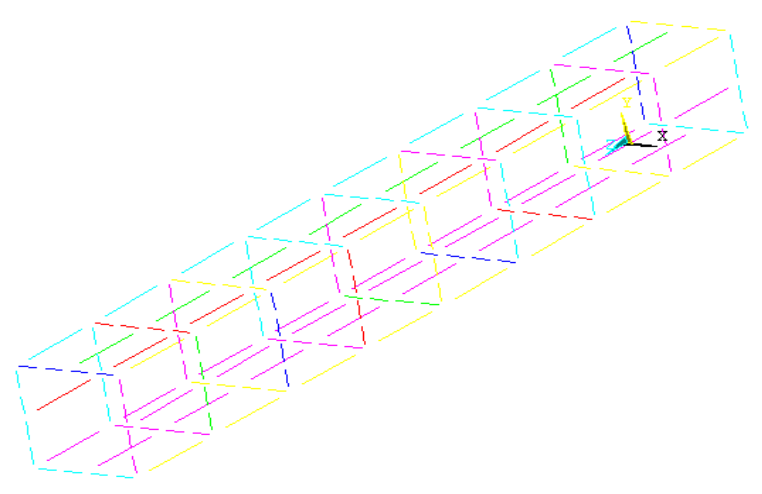

(c)

FIGURA 5.3 - Discretização da Armadura

\subsection{2 - GRÁFICOS ILUSTRATIVOS}

As figuras de 5.4 a 5.15 mostram a análise entre os diagramas Força $\mathrm{x}$ Deformação dos pilares obtidos experimentalmente e os resultados obtidos através da análise numérica.

Pode-se perceber que as forças resistentes obtidas com o procedimento numérico ficaram sempre com valores acima das forças últimas experimentais. Isto ocorreu porque o processo numérico foi feito considerando-se a seção total do pilar, enquanto que na análise feita no item 5.2, percebeu-se que a seção resistente do pilar é formada pelo núcleo da seção transversal. 


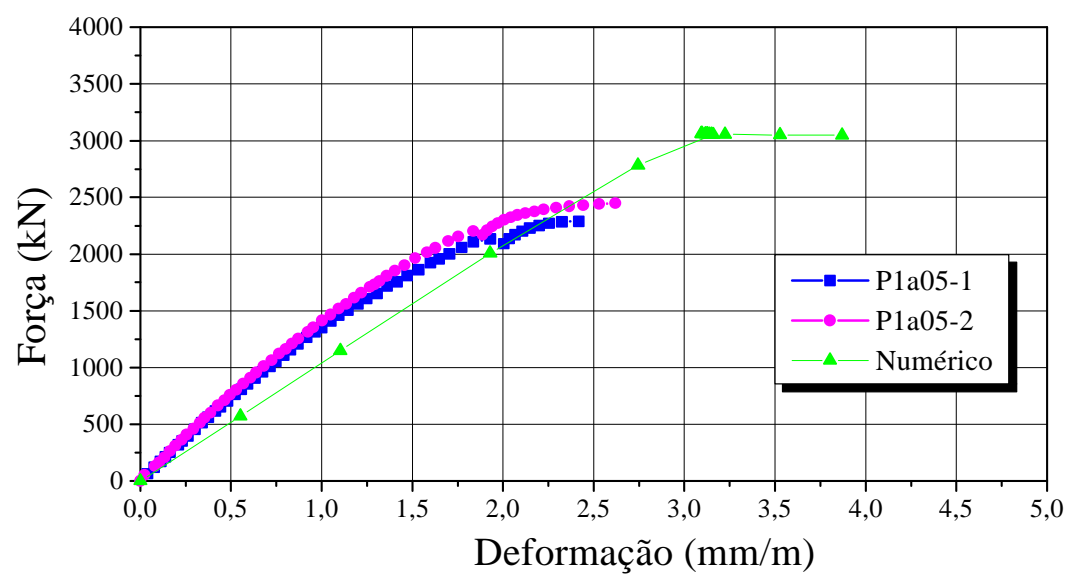

FIGURA 5.4 - Análise Experimental e Numérica da Série P1a05

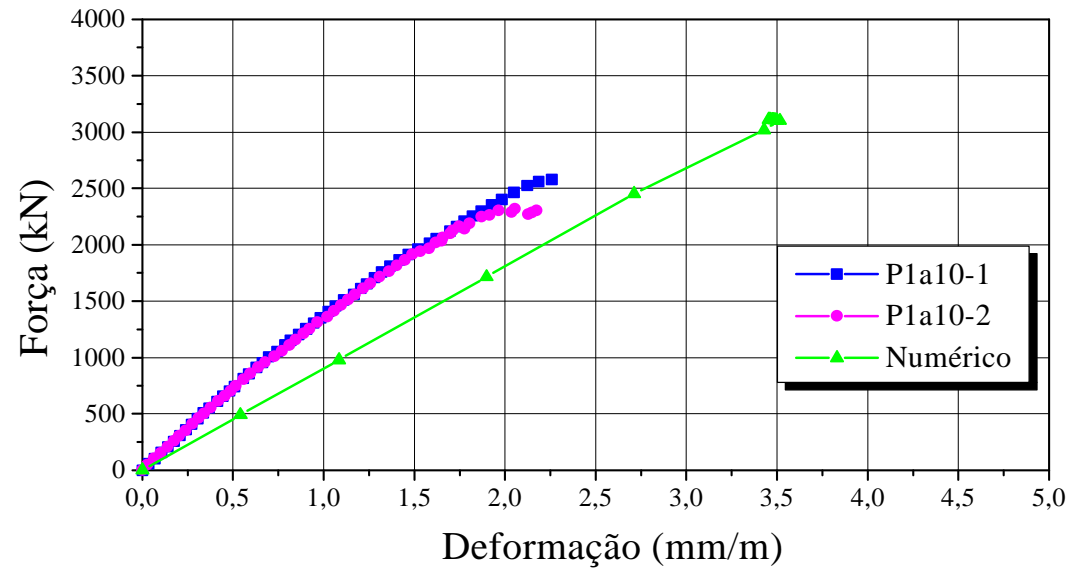

FIGURA 5.5 - Análise Experimental e Numérica da Série P1a10

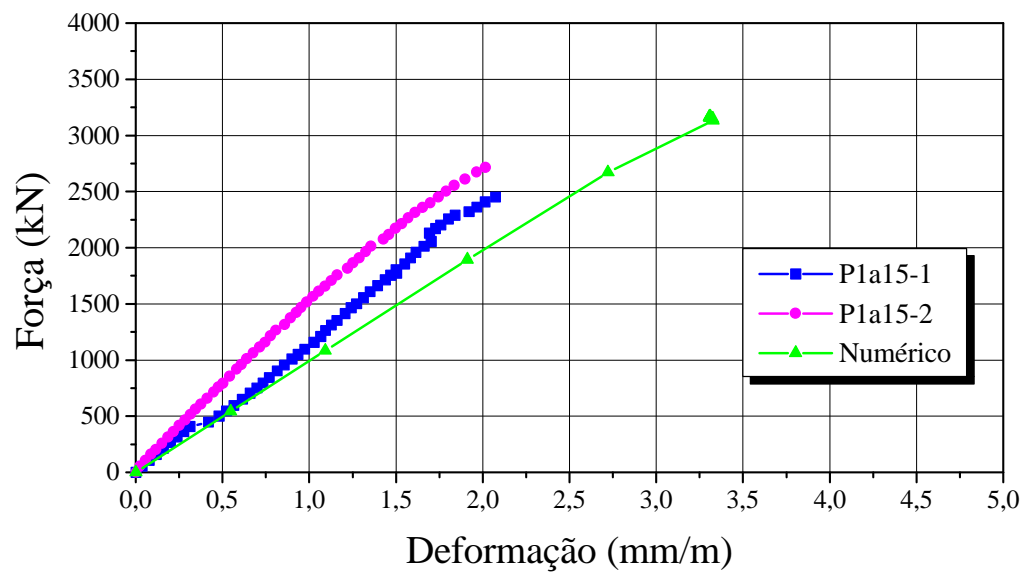

FIGURA 5.6 - Análise Experimental e Numérica da Série P1a15 


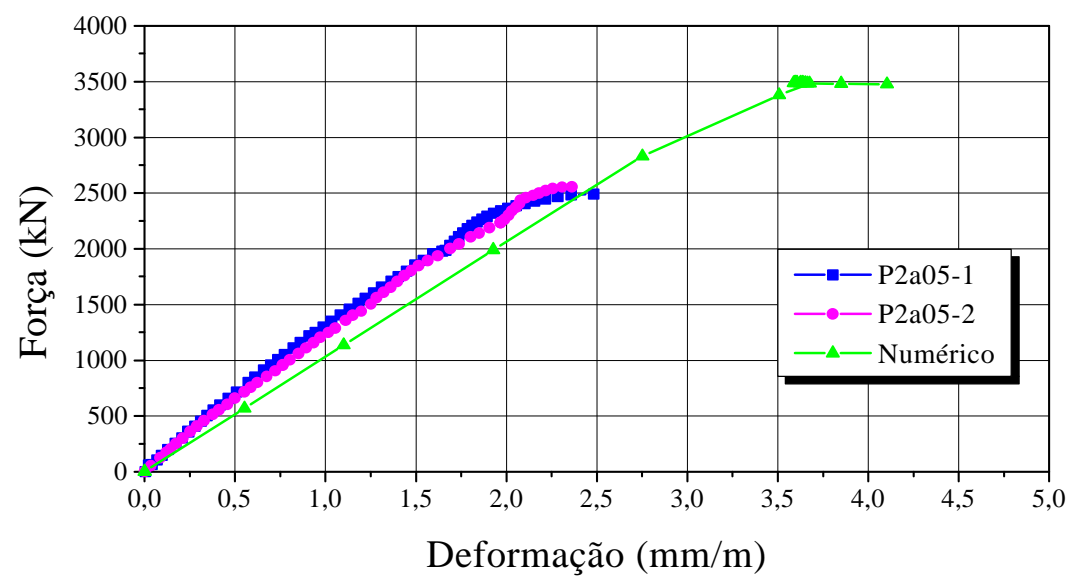

FIGURA 5.7 - Análise Experimental e Numérica da Série P2a05

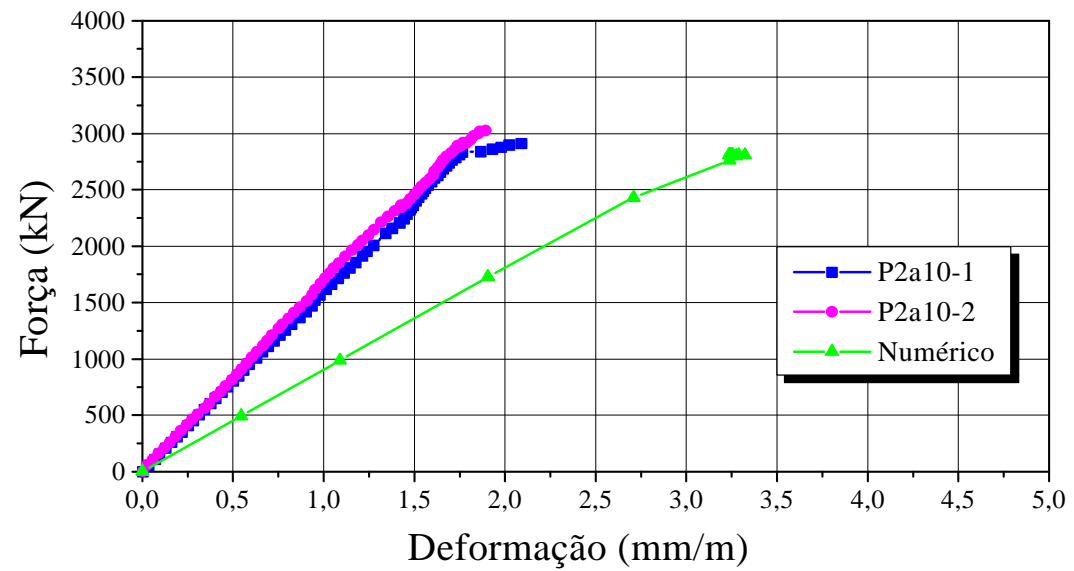

FIGURA 5.8 - Análise Experimental e Numérica da Série P2a10

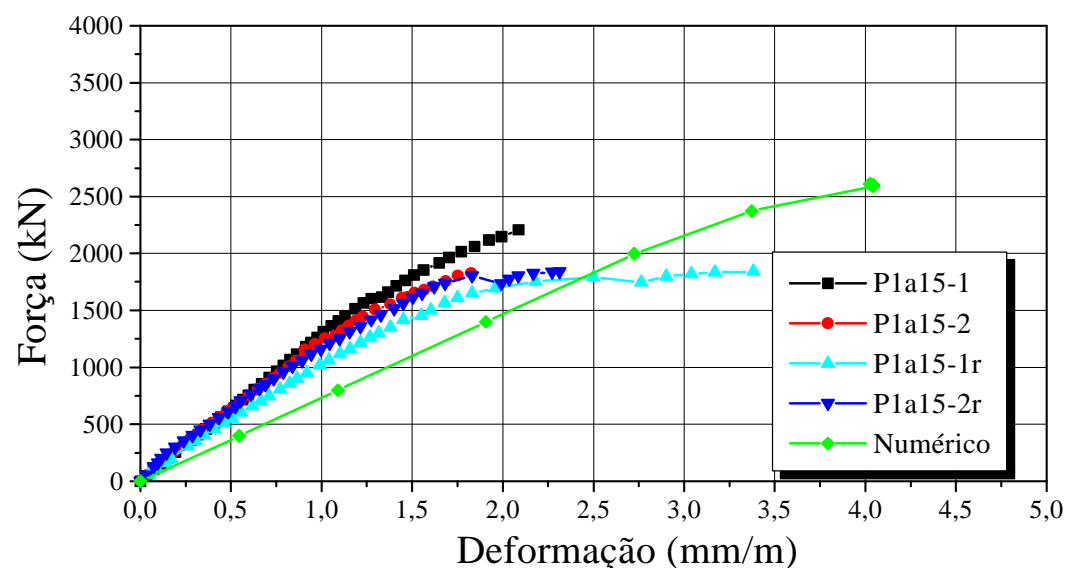

FIGURA 5.9 - Análise Experimental e Numérica da Série P2a15 


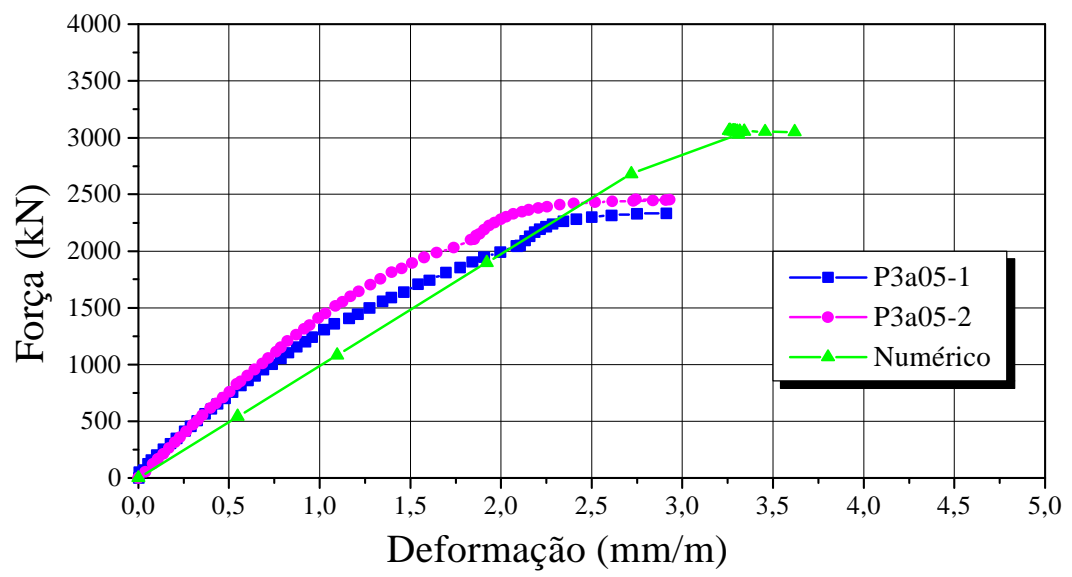

FIGURA 5.10 - Análise Experimental e Numérica da Série P3a05

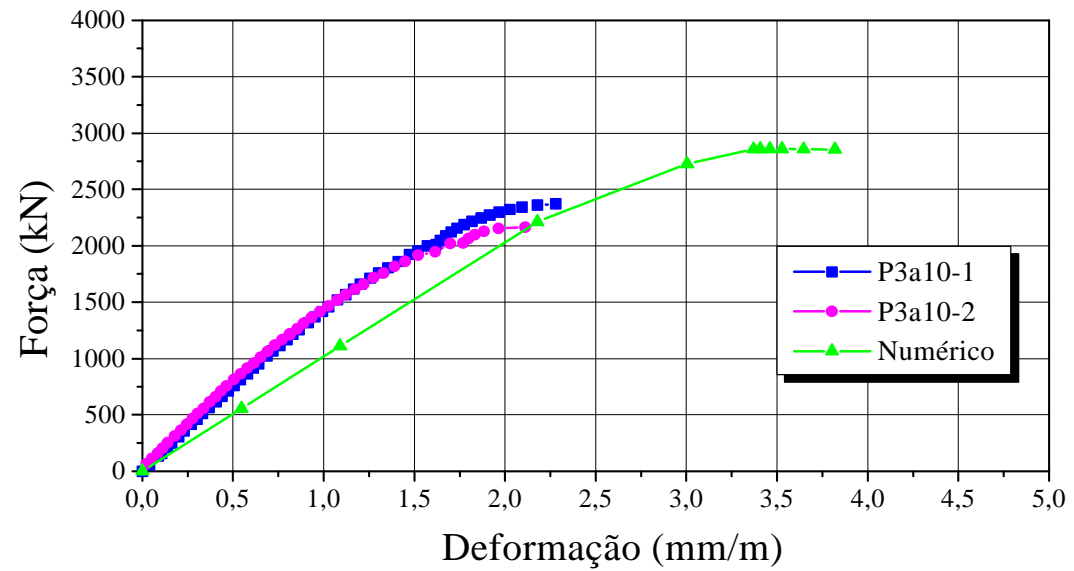

FIGURA 5.11 - Análise Experimental e Numérica da Série P3a10

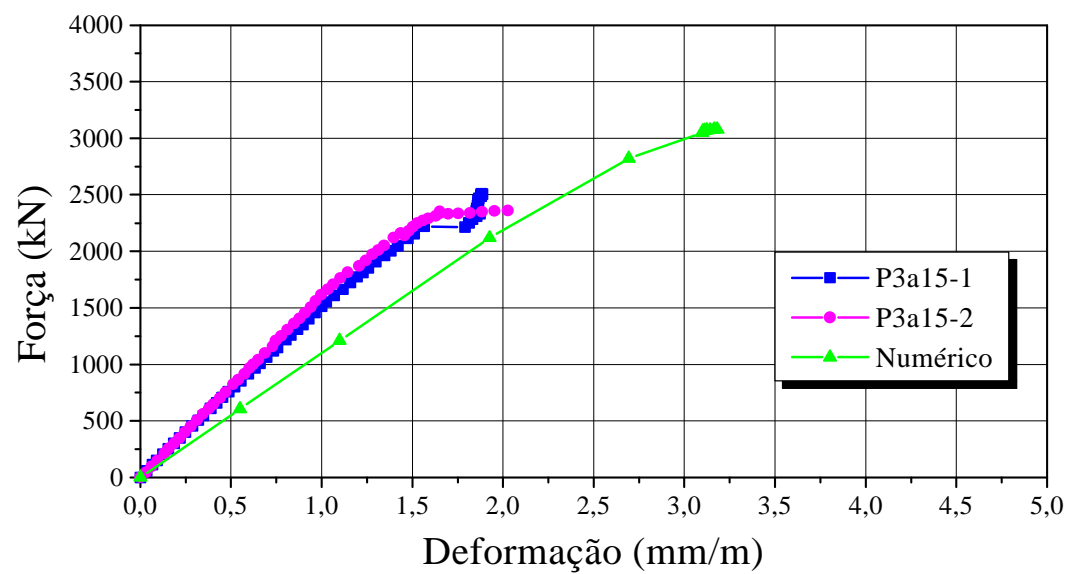

FIGURA 5.12 - Análise Experimental e Numérica da Série P3a15 


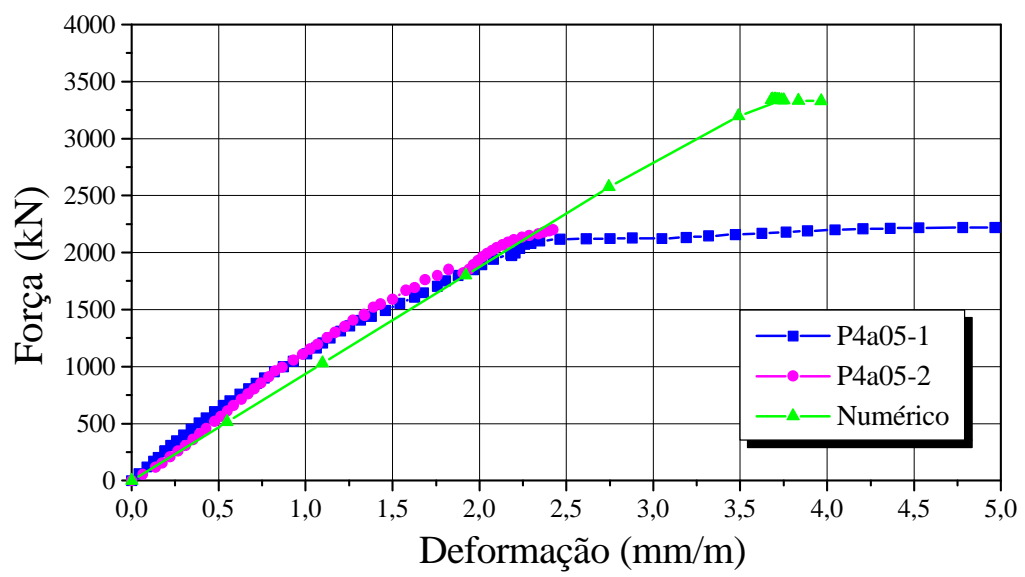

FIGURA 5.13 - Análise Experimental e Numérica da Série P4a05

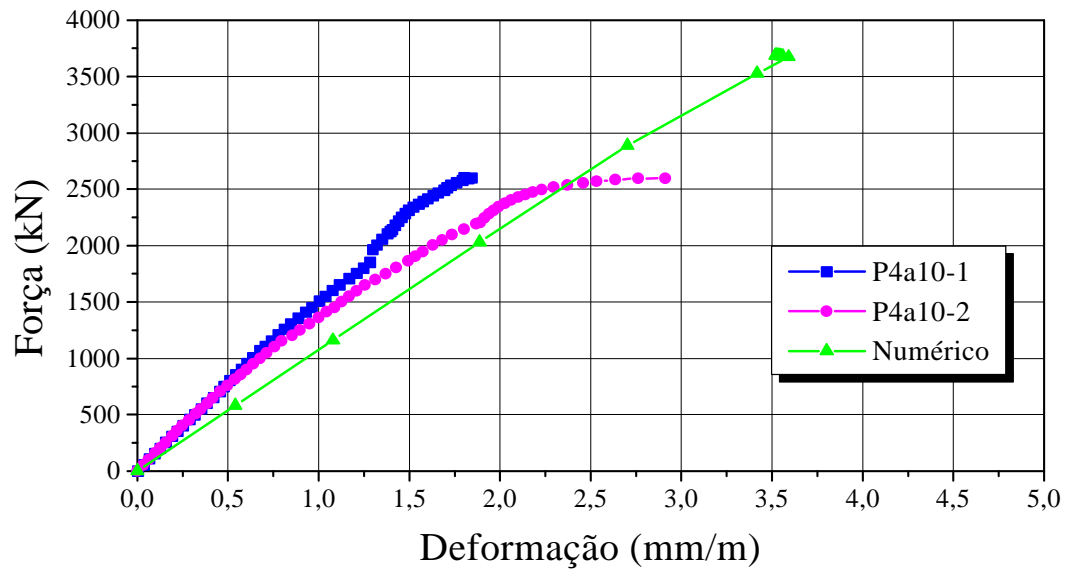

FIGURA 5.14 - Análise Experimental e Numérica da Série P4a10

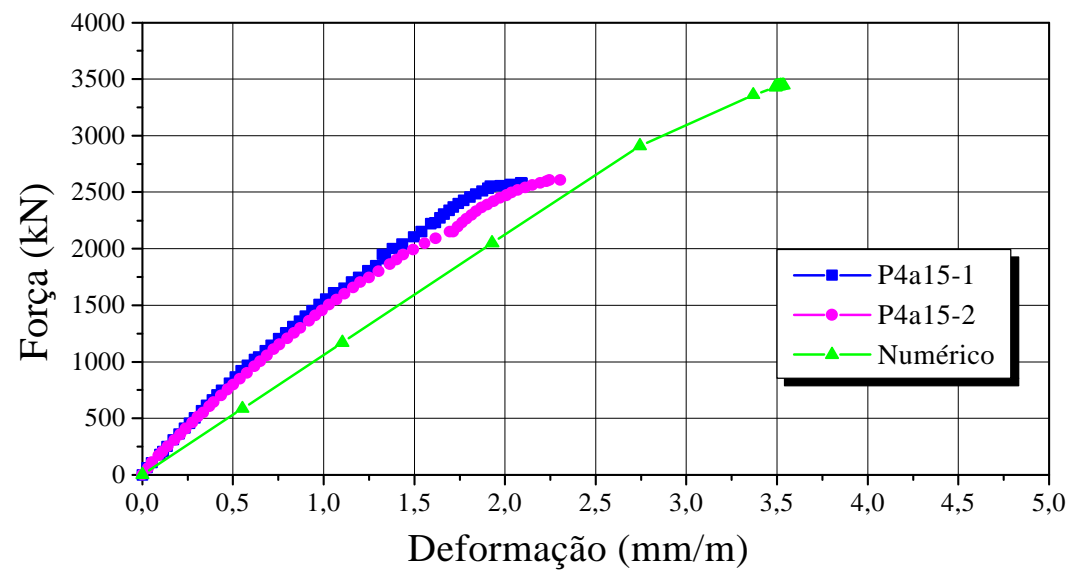

FIGURA 5.15 - Análise Experimental e Numérica da Série P4a15 


\section{4 - COMPARAÇÃO COM OS RESULTADOS DE LIMA et al.(1997)}

Na tabela 5.3 são mostrados os resultados obtidos por LIMA(1997), em pesquisa feita com pilares de concreto de alta resistência sem adição de fibras.

Percebe-se que a conclusão obtida pelo pesquisador, e que se confirma nesta pesquisa, é a de que apenas o núcleo do pilar, delimitado pelos estribos, forma a seção resistente.

Tabela 5.3 - Resultados dos ensaios feitos por LIMA et al.(1997)

\begin{tabular}{|c|c|c|c|c|c|c|c|c|}
\hline Pilar & $\begin{array}{c}\rho_{\mathbf{w}} \\
(\%)\end{array}$ & $\begin{array}{c}\text { Estribos } \\
(\mathbf{c m})\end{array}$ & $\begin{array}{c}\boldsymbol{\rho}_{\ell} \\
(\boldsymbol{\%})\end{array}$ & $\begin{array}{c}\mathbf{A}_{\mathbf{c n}} \\
\left(\mathbf{c m}^{2}\right)\end{array}$ & $\begin{array}{c}\mathbf{0 , 9}_{\mathbf{c m}} \\
(\mathbf{M P a})\end{array}$ & $\begin{array}{c}\mathbf{F}_{\mathbf{u}, \mathbf{e x p}} \\
(\mathbf{k N})\end{array}$ & $\begin{array}{c}\mathbf{F}_{\text {un,teo }} \\
(\mathbf{k N})\end{array}$ & $\begin{array}{c}\mathbf{F}_{\mathbf{u}, \mathbf{e x p}} \\
/ \mathbf{F}_{\mathbf{u}, \text { teo }}\end{array}$ \\
\hline $\mathrm{P} 1 / 1$ & 1,63 & $\phi 6,3 \mathrm{c} / 05$ & 2,34 & 251,86 & 75,40 & 2.630 & 2.375 & 1,11 \\
\hline $\mathrm{P} 1 / 2$ & 1,63 & $\phi 6,3 \mathrm{c} / 05$ & 2,34 & 251,86 & 75,40 & 2.701 & 2.375 & 1,14 \\
\hline $\mathrm{P} 1 / 3$ & 1,63 & $\phi 6,3 \mathrm{c} / 05$ & 2,34 & 251,86 & 75,40 & 2.834 & 2.375 & 1,19 \\
\hline $\mathrm{P} 1 \mathrm{r} / 2$ & 1,63 & $\phi 6,3 \mathrm{c} / 05$ & 2,34 & 251,86 & 76,60 & 3.063 & 2.403 & 1,27 \\
\hline $\mathrm{P} 1 \mathrm{r} / 3$ & 1,63 & $\phi 6,3 \mathrm{c} / 05$ & 2,34 & 251,86 & 76,60 & 2.820 & 2.403 & 1,17 \\
\hline $\mathrm{P} 2 / 2$ & 0,82 & $\phi 6,3 \mathrm{c} / 10$ & 2,34 & 251,86 & 78,70 & 2.950 & 2.454 & 1,20 \\
\hline $\mathrm{P} 2 / 3$ & 0,82 & $\phi 6,3 \mathrm{c} / 10$ & 2,34 & 251,86 & 82,80 & 3.210 & 2.554 & 1,26 \\
\hline
\end{tabular}

\section{5 - CONSIDERAÇÕES FINAIS}

Neste capítulo procurou-se trabalhar com os resultados experimentais, confrontando-os com uma análise teórica, uma análise numérica e com os resultados de outros pesquisadores. No próximo capítulo se apresentam as conclusões que foram obtidas nessas análises e também algumas indicações de continuidade da pesquisa. 
A utilização do cimento de alta resistência inicial (ARI), permitiu um ganho de resistência muito alto nos primeiros dias de idade do concreto. Até os 7 primeiros dias os concretos das 4 séries tiveram ganhos significativos de resistência, não ocorrendo o mesmo de 7 dias para 15 dias, onde o acréscimo de resistência foi muito menor. De 15 dias para 28 dias o ganho de resistência foi menor ainda, e para algumas séries permaneceu quase inalterada.

O aumento do valor do módulo de elasticidade não é constante desde as primeiras idades, foi observado um pequeno aumento nos seus valores com o passar dos dias. Este aumento acompanhou a variação da resistência à compressão, isto é, maior de 3 dias para 15 dias, estabilizando de 15 dias para 28 dias. Isto foi verificado em todas as séries estudadas para definir a dosagem que foi usada nas moldagens dos pilares (7 no total).

A variação de resistência média à compressão com a adição de fibras foi relativamente pequena. Note-se que as séries $\mathrm{C}$ e $\mathrm{D}$ tiveram comportamento muito semelhante. A série $\mathrm{C}$ continha $0,25 \%$ de taxa volumétrica de fibras de aço, enquanto que a série D não continha fibras. 
Para se obter boa trabalhabilidade no concreto de alta resistência com adição de fibras foi necessário o uso de aditivos superplastificantes com taxas relativamente altas, pois a relação água/cimento utilizada foi baixa.

Para este trabalho foram adotadas taxas de 3\% de aditivo superplastificante e $0,3 \%$ de aditivo plastificante retardador de pega, para que os corpos-de-prova e os modelos pudessem ser moldados sem que o início de pega do concreto se desse antes do tempo desejado. Posteriormente o uso do aditivo retardador de pega foi descartado, pois viu-se que pelo tempo gasto para moldagem dos pilares, sua adição à mistura não era necessária.

Após a execução dos ensaios pilotos verificou-se que as fibras metálicas que foram utilizadas no concreto, com $2,4 \mathrm{~cm}$ de comprimento, não foram arrancadas e sim rompidas. Optou-se então por trabalhar com fibras mais longas, $6,0 \mathrm{~cm}$ de comprimento, seguindo indicação do Prof. Newton de Oliveira Pinto Jr. de que o comprimento das fibras deveria ser de duas a três vezes o diâmetro máximo do agregado graúdo. Com a mudança das dimensões das fibras, o concreto passou a ter aumento de tenacidade, e isto foi verificado pela forma de ruptura dos pilares, que foi mais dúctil, com as fibras sendo arrancadas e não mais rompidas.

Nos ensaios com deformação controlada dos corpos-de-prova pôde ser observado que, quanto maior a adição de fibras no concreto, maior o índice de tenacidade e a resistência à tração também era maior nos ensaios feitos com compressão diametral.

Isto também foi verificado nos ensaios dos pilares onde, com a instrumentação colocada no concreto nas faces dos pilares, puderam ser medidas as deformações na direção transversal. Foi observado que na proximidade da ruína houve aumento das deformações nos estribos da mesma maneira que no concreto, ou seja, na proporção crescente com a quantidade de fibras adicionadas ao concreto, e ficando muito claro para as séries com maior taxa de fibras adotada na pesquisa (1\%), evidenciando assim a ductilização dos pilares.

$\mathrm{O}$ aumento da quantidade de fibras no concreto aumentou discretamente a deformabilidade do pilar como um todo. O aumento das deformações ficou evidenciado devido ao aumento da taxa de armadura transversal. 
Foi notado que a armadura longitudinal teve maiores deformações, no estágio próximo à ruína, e para algumas séries também em serviço, do que as deformações obtidas em LIMA(1997). Este aumento também pode ser notado comparando-se os gráficos das séries de pilares desta pesquisa, com relação ao aumento da taxa de fibras e da armadura transversal.

Percebeu-se nos ensaios que o cobrimento não é destacado antes da ruptura. As fibras fizeram um elo de ligação não permitindo a ruptura do concreto do cobrimento com uma força menor que a de ruína, como acontecia com os pilares de concreto de alto desempenho sem adição de fibras, onde ocorria a ruptura do núcleo depois da ruptura do cobrimento, como foi observado por AGOSTINI(1995), CUSSON \& PAULTRE(1994) e LIMA, GIONGO \& TAKEYA(1997), nos ensaios de pilares com concreto de alto desempenho, porém, sem adição de fibras.

Conforme PAULTRE(1994), o ângulo de ruptura do núcleo de concreto confinado varia de $25^{\circ}$ a $45^{\circ}$, dependendo da intensidade do confinamento do núcleo, sendo maior o ângulo quanto menor o confinamento, e isto foi verificado nos ensaios desta pesquisa, com a maioria dos casos ocorrendo com ângulos de $45^{\circ}$. Isto pode ser observado nas fotografias mostradas no Apêndice B.

Assim como foi verificado por outros pesquisadores, apenas o núcleo dos pilares, delimitado pelos estribos, formou a seção resistente aos esforços normais de compressão. Nos pilares feitos com concreto de alta resistência com fibras metálicas a conclusão não foi diferente, ou seja, apenas o núcleo da seção transversal contribuiu para absorver a força atuante. Isto pôde ser comprovado também na análise numérica onde, considerando-se a seção transversal total dos modelos, a força resistente obtida foi maior que a força última experimental, mostrado nos diagramas Tensão x Deformação do capítulo 5.

Indica-se o uso de no máximo h/2 para o espaçamento entre estribos, onde h é a altura da seção transversal do pilar, visto que para os pilares com espaçamento entre estribos a cada $15 \mathrm{~cm}$ (12 $\phi$ ' indicado pela NB1) houve ductilidade na ruptura apenas para a taxa de fibras de $1 \%$, assim mesmo com a flambagem da armadura longitudinal. 
Pôde-se perceber, pelos diagramas das séries de pilares mostrados no capítulo 4, que à partir da adição de $0,75 \%$ de taxa de fibras metálicas, houve ganho nas deformações das armaduras, que chegaram ao patamar de escoamento.

\section{1 - CONTINUIDADE DA PESQUISA}

Esta pesquisa sobre pilares de concreto de alto desempenho com adição de fibras, pode gerar outros trabalhos na mesma linha. Existem outras idéias que poderiam ser postas em práticas à partir deste estudo, e aqui vão algumas sugestões de pesquisas futuras, que poderiam ser iniciadas em curto período de tempo.

Foi feita apenas uma série de pilares com fibras de polipropileno e o resultado dos ensaios dos pilares propicia um estudo mais elaborado, podendo ser variada a taxa de estribos, a taxa de fibras adicionadas ao concreto, assim como feito com as fibras metálicas.

Foram ensaiados pilares sob ação da compressão centrada. Poder-se-á elaborar testes de pilares sob efeito de flexão, reta ou oblíqua, tentando simular o caso real dos pilares de edifícios.

A ação aplicada nos modelos desta pesquisa foi estática. Pode-se fazer ensaios de compressão centrada sob efeito de ação cíclica, sendo que isto é o que ocorre em estruturas construídas em regiões sujeitas à abalos sísmicos.

O arranjo de estribos utilizado para construção dos pilares foi o mais simples possível. Poder-se-iam fazer arranjos mais elaborados (PAULTRE et al.(1996)), utilizar fibras no concreto e executar os ensaios sob ação dinâmica ou ainda estática, visando analisar o comportamento do modelo quanto à ductilidade. É possível a análise de pilares com tubos metálicos em substituição aos estribos, formando estrutura mista aço-concreto.

A análise numérica feita neste estudo, obteve apenas o ramo ascendente da curva Tensão x Deformação dos pilares. Poder-se-ia, com uso de outros programas numéricos, obter curvas Tensão x Deformação com ramo ascendente e descendente, levando em conta a adição de fibras ao concreto. 


\section{1 - REFERÊNCIAS BIBLIOGRÁFICAS}

AGOPYAN, V.(1991). Materiais reforçados com fibras para a construção civil nos países em desenvolvimento: o uso de fibras vegetais. São Paulo. Tese (Livre docência) - EPUSP.

AGOSTINI, L. R. S.(1992). Pilares de concreto de alta resistência. São Paulo. Tese (Doutorado) - EPUSP.

AITCIN, P. C.; NEVILLE, A.(1993). High-performance concrete demystified. Concrete International, v.15, n.1, p.21-26.

AMERICAN CONCRETE INSTITUTE. Committee 363(1992). State-of-the-art report on high strength concrete. Detroit, (ACI 363R-92).

AMERICAN CONCRETE INSTITUTE(1994). ACI 544.1R-86 - State of the art report on fiber reinforced concrete. In: ACI manual of concrete pratice. Detroit. part 5. 
AMERICAN CONCRETE INSTITUTE(1994). ACI 544.3R-93 - Guide for specifying, proportioning, mixing, placing, and finishing steel fiber reinforced concrete. In: ACI manual of concrete pratice. Detroit. part 5.

AMERICAN CONCRETE INSTITUTE(1994). ACI 544.4R-88 - Design considerations for steel fiber reinforced concrete. In: ACI manual of concrete pratice. Detroit. part 5.

AMERICAN SOCIETY FOR TESTING AND MATERIALS(1992). ASTM C 494 Chemical admixtures for concrete. Philadelphia.

ANSYS(1997). version 5.4. Houston, USA.

ASSOCIAÇÃO BRASILEIRA DE NORMAS TÉCNICAS(1978). NB 1 - Projeto e execução de obras de concreto armado. Rio de Janeiro.

ASSOCIAÇÃO BRASILEIRA DE NORMAS TÉCNICAS(1982). NBR 7222 Argamassas de concretos - determinação da resistência à tração por compressão diametral de corpos-de-prova cilíndricos. Rio de Janeiro.

ASSOCIAÇÃO BRASILEIRA DE NORMAS TÉCNICAS(1983). NBR 7809 Agregado graúdo - determinação do índice de forma pelo método do paquímetro. Rio de Janeiro.

ASSOCIAÇÃO BRASILEIRA DE NORMAS TÉCNICAS(1983). NBR 7211 Agregado para concreto. Rio de Janeiro.

ASSOCIAÇÃO BRASILEIRA DE NORMAS TÉCNICAS(1983). NBR 8522 Concreto - determinação do módulo de deformação estática e diagrama tensão deformação. Rio de Janeiro.

ASSOCIAÇÃO BRASILEIRA DE NORMAS TÉCNICAS(1984). NBR 6474 Cimento portland comum e outros materiais em pó - determinação da massa específica. Rio de Janeiro.

ASSOCIAÇÃO BRASILEIRA DE NORMAS TÉCNICAS(1987). NBR 7217 Agregados - determinação da composição granulométrica. Rio de Janeiro.

ASSOCIAÇÃO BRASILEIRA DE NORMAS TÉCNICAS(1987). NBR 7219 Agregados - determinação do teor de materiais pulverulentos. Rio de Janeiro. ASSOCIAÇÃO BRASILEIRA DE NORMAS TÉCNICAS(1987). NBR 7251 Agregados em estado solto - determinação da massa unitária. Rio de Janeiro. 
ASSOCIAÇÃO BRASILEIRA DE NORMAS TÉCNICAS(1987). NBR 9776 Agregados - determinação da massa específica de agregados miúdos por meio do frasco de Chapman. Rio de Janeiro.

ASSOCIAÇÃO BRASILEIRA DE NORMAS TÉCNICAS(1991). NBR 12142 Concreto - determinação da resistência à tração na flexão. Rio de Janeiro.

ASSOCIAÇÃO BRASILEIRA DE NORMAS TÉCNICAS(1992). NBR 8953 Concreto para fins estruturais - classificação por grupos de resistência. Rio de Janeiro.

ASSOCIAÇÃO BRASILEIRA DE NORMAS TÉCNICAS(1992). NBR 11768 Aditivos para concreto de cimento Portland. Rio de Janeiro.

ASSOCIAÇÃO BRASILEIRA DE NORMAS TÉCNICAS(1992). NBR 12654 Controle tenológico de materiais componentes do concreto. Rio de Janeiro.

ASSOCIAÇÃO BRASILEIRA DE NORMAS TÉCNICAS(1997). Texto para revisão da NB-1 e comentários.

BALAGURU, P.N.; SHAH, S.P.(1992). Fiber-reinforced cement composites. Singapore, McGraw-Hill.

BENTUR, A.; MINDESS, S.(1990). Fibre reinforced cementitious composites. London, Elsevier Applied Science.

CARRASQUILLO, R.L.; NILSON A.H.; SLATE F.O.(1981). Properties of high strength concrete subject to short-term loads. ACI Journal. v.78, n.3, p.171-178, May-June.

CEB-FIP WORKING GROUP ON HIGH STRENGTH CONCRETE(1990). High strength concrete - state of the art report. CEB Bulletin d'Information, n.197, Aug.

CEB-FIP WORKING GROUP ON HIGH STRENGTH CONCRETE(1995). High performance concrete. CEB Bulletin d'Information, n.228, July.

CECCATO, M.R.; NUNES, N.L.; FIGUEIREDO, A.D.(1997). Estudo do controle da trabalhabilidade do concreto reforçado com fibras de aço. In: CONGRESSO IBEROAMERICANO DE PATOLOGIA DAS CONSTRUÇÕES, 4./ CONGRESSO DE CONTROLE DA QUALIDADE, 6., Porto Alegre, 21-24 out. 1997. Anais. Porto Alegre, UFRGS-CPGEC. v. 2, p. 539-546. 
CLAESON, C.; GYLLTOFT, K.; GRAUERS, M.(1996). Experiments and numerical analyses of reinforced high strength concrete columns. In: INTERNATIONAL SIMPOSIUM ON THE UTILIZATION OF HIGH STRENGTH/ HIGH PERFORMANCE CONCRETE, 4., Paris, France, 29-31 May. Proceedings. v.3. p.797-806.

COLliNS, M.P.; MITCHELL, D.; MacGREGOR, J.G.(1993). Structural design considerations for high-strength concrete. Concrete International, v.15, n.1, p.27-34.

CUSSON, D.; PAULTRE, P.(1994). High-strength concrete columns confined by retangular ties. Journal of Structural Engineering, ASCE, v.120, n.3, p.783804, Mar.

DAL MOLIN, D.C.C.(1995). Contribuição ao estudo das propriedades mecânicas dos concretos de alta resistência com e sem adições de microssílica. São Paulo. Tese (Doutorado) - EPUSP.

FIGUEIREDO, A.D.(1997). Parâmetros de controle e dosagem do concreto projetado com fibras de aço. São Paulo. Tese (Doutorado) - EPUSP.

FURLAN, S.(1995). Vigas de concreto com taxas reduzidas de armadura de cisalhamento: influência do emprego de fibras curtas e protensão. São Carlos. Tese (Doutorado) - Escola de Engenharia de São Carlos, Universidade de São Paulo.

GIONGO, J.S.; GUIMARÃES, A.E.P.; TAKEYA, T.(1998). Análise experimental de pilares de concreto armado de alto desempenho com adição de fibras. São Carlos. Escola de Engenharia de São Carlos - USP. (Relatório de AuxílioPesquisa apresentado à FAPESP - Processo: 97/00932 - 6).

GONZALES-ISABEL, G.(1993). Hormigon de alta resistencia. Madrid, INTEMAC.

GUIMARÃES, A.E.G.; GIONGO, J.S.; LIMA, F.B.(1997). Obtenção de um concreto de alta resistência com adição de sílica ativa e fibras metálicas para utilização em pilares. In: REUNIÃO DO INSTITUTO BRASILEIRO DO CONCRETO, 39., São Paulo. Anais. v.2, p.549-562. 
GUIMARÃES, A.E.G.; GIONGO, J.S. \& LIMA, F.B.(1998). Comparative study of high performance concrete with steel fibres. In: INTERNATIONAL CONFERENCE ON RECENT ADVANCES IN CONCRETE TECHNOLOGY, 4., Tokushima, Japan, June 7-11. 1998. Supplementary papers. p.119-213.

GUIMARÃES, A.E.G.; GIONGO, J.S.; TAKEYA, T.(1998). Análise experimental de pilares de concreto de alto desempenho com adição de fibras submetido à compressão axial. In: Congresso Brasileiro do Concreto, 40., Rio de Janeiro. Anais(CD-ROM).

GUIMARÃES, A.E.G.; GIONGO, J.S.; TAKEYA, T.(1999). Axially loaded HPC columns with steel fibres. In: INTERNATIONAL CONFERENCE ON HIGHPERFORMANCE CONCRETE, AND PERFORMANCE AND QUALITY OF CONCRETE STRUCTURES, 2., Gramado, Brasil. Proceedings.

HELENE, P.R.L.; TERZIAN, P.(1992). Manual de dosagem e controle do concreto. São Paulo, Pini. 349p.

KÖNIG, G.; SIMSCH, G.(1996). Failure mechanism and load-deformation behaviour of high strength concrete columns with confining reinforcement. In: FOURTH INTERNATIONAL SIMPOSIUM ON THE UTILIZATION OF HIHG STRENGTH/ HIGH PERFORMANCE CONCRETE, 4., Paris, France, 29-31 May. Proceedings. v.3, p. 777-786.

LANGLOIS, Y.; PAULTRE, P.(1996). Rôle de l'enrobage de béton et effet des fibres métalliques sur le comportement des poteaux en BHP. Sherbrooke, Canadá, Université de Sherbrooke. (Rapport de recherche, SMS-96/02).

LEVESQUE, Y.(1998). Étude de la ductilité des poteaux en béton armé a haute performance avec fibres métalliques. Sherbrooke, Canadá. Mémoire de maîtrise ès sciences appliquées - Université de Sherbrooke.

LIMA, F.B.(1997). Pilares de concreto de alto desempenho: fundamentos e experimentação. São Carlos. Tese (Doutorado) - Escola de Engenharia de São Carlos, Universidade de São Paulo.

MEHTA, P. K.; MONTEIRO, P. J. M.(1994). Concreto: estrutura, propriedades e materiais. São Paulo, Pini. 573p. 
NAAMAN, A.E. et al.(1993). High early strength fiber reinforced concrete. IN:Mechanical Behaviour of High Performance Concretes, v.6, University of Michigan, Ann Arbor. (Strategic Highway Research Program - National Research Council - Washington, DC).

NEVILLE, A.M.(1997). Propriedades do concreto. 2.ed., São Paulo, Pini. (tradução de Salvador E. Giammusso).

NORWEGIAN COUNCIL FOR BUILDING STANDARDIZATION(1992). NS 3473E - Concrete structures - design rules. 4.ed. Oslo, NSF.

PAULTRE, P. et al.(1996). Structural performance of some special concretes. In: INTERNATIONAL SIMPOSIUM ON THE UTILIZATION OF HIHG STRENGTH/ HIGH PERFORMANCE CONCRETE, 4., Paris, France, 29-31 May. Proceedings. v.3. p.787-796.

PINTO Jr., N.O.; BINA, P.(1996). Pisos industriais construídos com concreto dosado com fibras. In: REUNIÃO DO INSTITUTO BRASILEIRO DO CONCRETO, 38., Ribeirão Preto, 19-23 ago. Anais. v.1, p.63-78.

PINTO Jr., N.O.; MORAES, A.A.(1996). Concreto reforçado com fibras. In: REUNIÃO DO INSTITUTO BRASILEIRO DO CONCRETO, 38., Ribeirão Preto, 19-23 ago. Anais. v.2, p.471-480.

REGATTIERI, C.E.X. et al.(1996). Estudo de algumas propriedades do concreto reforçado com fibras de aço e polipropileno destinados a pavimentos. In: REUNIÃO DO INSTITUTO BRASILEIRO DO CONCRETO, 38., Ribeirão Preto, 19-23 ago. Anais. v.1, p.1-14.

SILVA, P.F.A.; MENTONE, F.J.; PITTA, A.C.(1996). Controle de qualidade de pavimentos de concreto contendo fibras: um caso real. In: REUNIÃO DO INSTITUTO BRASILEIRO DO CONCRETO, 38., Ribeirão Preto, 19-23 ago. Anais. v.1, p.15-22.

SHAH, S.P.(1996). Special HPCs: fiber-reinforced HPC, ultra-high strength concrete. In: INTERNATIONAL SIMPOSIUM ON THE UTILIZATION OF HIGH STRENGTH/ HIGH PERFORMANCE CONCRETE, 4., Paris, France, 29-31 May. Proceedings. v.1. p. 75-81. 
THE JAPAN SOCIETY OF CIVIL ENGINEERS(1984). JSCE-SF5 Method of tests for compressive strenght and compressive toughness of steel fiber reinforced concrete n.3 part III-2 Method of Tests for Steel Fiber Reinforced Concrete, June.

VASCONCELOS, A.C.(1998). Concreto de alto desempenho - C.A.D./ Palestra ministrada no Departamento de Engenharia de Estruturas da Escola de Engenharia de São Carlos - Universidade de São Paulo/.

WEBB, J.(1993). High-strength concrete: economics, design and ductility. Concrete International, v.15, n.1, p.27-32.

ZAMBRANA VARGAS, E.N.(1997). Punção em lajes-cogumelo de concreto de alta resistência reforçado com fibras de aço. São Carlos. Dissertação (Mestrado) - Escola de Engenharia de São Carlos, Universidade de São Paulo.

\section{2 - BIBLIOGRAFIA COMPLEMENTAR}

AMERICAN CONCRETE INSTITUTE(1994). ACI 544.2R - 89 - Measurements of properties of fiber reinforced concrete. In: ACI manual of concrete pratice. Detroit. part 5.

CARETTE; MALHOTRA; AÏTCIN, P.C.(1989); Preliminary data on long-term strength concrete development of condensed silica fume concrete, INTERNATIONAL CONFERENCE ON FLY ASH, SILICA FUME, SLAG/NATURAL POZZOLANS IN CONCRETE, 3., Trondheim, Norway Supplementary Papers. p.597-617.

CARINO, N.J.; CLIFTON, J.R.(1991). High-performance concrete: research needs to enhance its use. Concrete International, v.13, n.9, p.70-76.

COLACO, J. P.(1985). 75-Story Texas commerce plaza, Houston - the use of highstrength concrete. In: RUSSEL, H. G., ed. High-strength concrete. Detroit, ACI. p.1-8 (SP-87)

CUSSON, D.; DE LARRARD, F.; BOULAY C. \& PAULTRE, P.(1996). Modeling of the post-peak behaviour of confined high performance concrete columns - the strain localization approach. In: INTERNATIONAL SIMPOSIUM ON THE 
UTILIZATION OF HIGH STRENGTH/ HIGH PERFORMANCE CONCRETE, 4., Paris, France, 29-31 May. Proceedings. v.3, p. 807-816.

DELVASTO, S.; NAAMAN, A.E.; THRONE, J.L.(1986). Effect of pressure after casting on high strength fibre reinforced mortar. The International Journal of Cement Composites and Lightweight Concrete, v.8, n.3, p.181-190.

DEWAR, J.D.(1964). The indirect tensile strength of concrete of high compressive strength. Wexham Springs. Cement and Concrete Association, Mar. 12p. (Technical Report n.42377)

FANELLA, D.A.; NAAMAN, A.E.(1985). Stress-strain properties of fiber reinforced mortar in compression. ACI Journal. p.475-483, July-August.

GJORV, O.E.(1992). High strength concrete. In: ADVANCES IN CONCRETE TECHNOLOGY, Athens. Proceedings, Montreal, CANMET. p.21-77.

INTERNATIONAL STANDARD ORGANIZATION(1987). Methods for assessment of compressive strength of concrete in structures. Draff Proposal ISO/TC71/SC3/WG May.

KOSA, K.; NAAMAN, A.E.(1990). Corrosion of steel fiber reinforced concrete. $\boldsymbol{A C I}$ Materials Journal. v.87, n.1, p.27-37, January-February.

KOSA, K.; NAAMAN, A.E.; HANSEN, W.(1991). Durability of fiber reinforced mortar. ACI Materials Journal. v.88, n.3, p.310-319, May-June.

LACROIX, R.; JAUGEY, P.(1985). High-strength concrete: how to use it every day. In: RUSSEL, H. G., ed. High-strength concrete. Detroit, ACI. p.1-8 (SP-87)

NEVILLE, A.; AÏTCIN, P.C.(1998). High performance concrete - an overwiew. Materials and Structure, v.31, p.111-117, Mars

NILSON, A. H.(1985). Design implications of current research on high-strength concrete. In: RUSSEL, H. G., ed. High-strength concrete. Detriot, ACI. p.85-118 (SP-87)

NILSON, A. H.(1990). Concreto de alta resistência-desempenho como material e comportamento estrutural. REUNIÃO ANUAL DO IBRACON, 30., Rio de Janeiro, Anais.

MAAGE, M.; SMEPLASS, S.; JOHANSEN, R.(1990). Long-term strength of high strength silica fume concrete. In: INTERNATIONAL SYMPOSIUM ON THE 
UTILIZATION OF HIGH STRENGTH CONCRETE, 2., Berkeley, USA, May. p.399-404.

MEHTA, P.K.; AITCIN, P.C.(1990). Microstructural basis of selection of materials and mix proportions for high strength concrete. In: INTERNATIONAL SYMPOSIUM ON UTILIZATION OF HSC, 2., May. Berkeley, p.265-286.

PAIVA, N. M. B.(1994). Pilares de concreto de alta resistência com seção transversal retangular solicitados à compressão simples. Campinas. Dissertação (Mestrado) - Faculdade de Engenharia Civil, Universidade Estadual de Campinas.

PEREIRA NETO, P.M.; DJANIKIAN, J.G.(1995). Algumas características do concreto de alta resistência com microssílica. São Paulo, EPUSP. 13p. (BT/PCC/143). 


\section{ENSAIOS COM DEFORMAÇ̃̃O CONTROLADA}

\section{A.1 - CONSIDERAÇÕES INICIAIS}

Neste apêndice são mostrados os gráficos dos ensaios dos corpos-de-prova de $10 \mathrm{~cm}$ x $20 \mathrm{~cm}$, feitos com deformação controlada em máquina de ensaios MTS, no Laboratório de Geotecnia da EESC-USP. 


\section{B.1 - CONSIDERAÇÕES INICIAIS}

Neste apêndice apresentam-se fotos dos ensaios das séries de pilares, onde as fotos do pilar piloto 1 e da série P2a10, não são mostradas devido a problemas técnicos com a máquina fotográfica. 


\section{B.2 - PILOTOS}
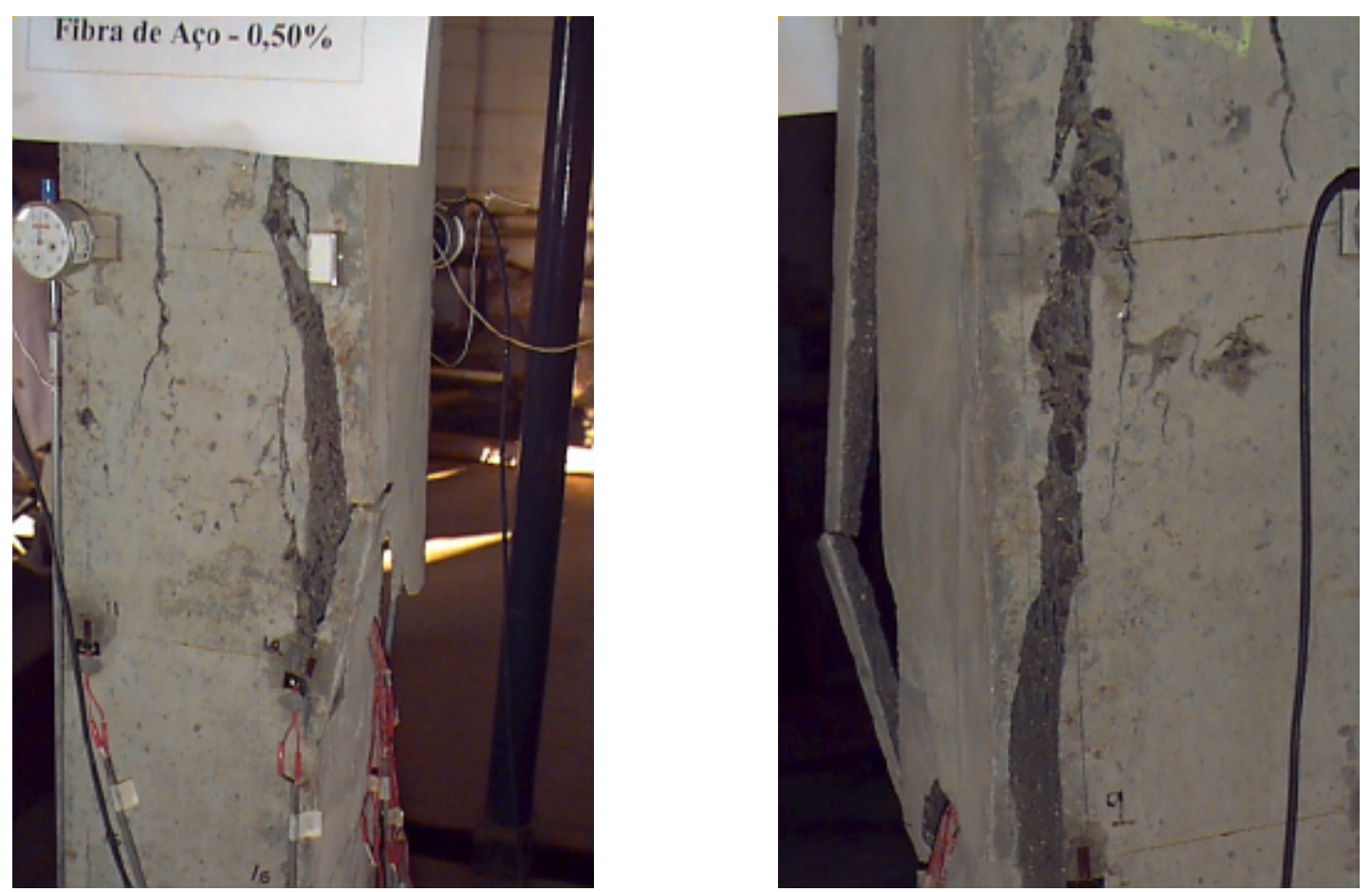

FIGURA B1 - Pilar Piloto 2
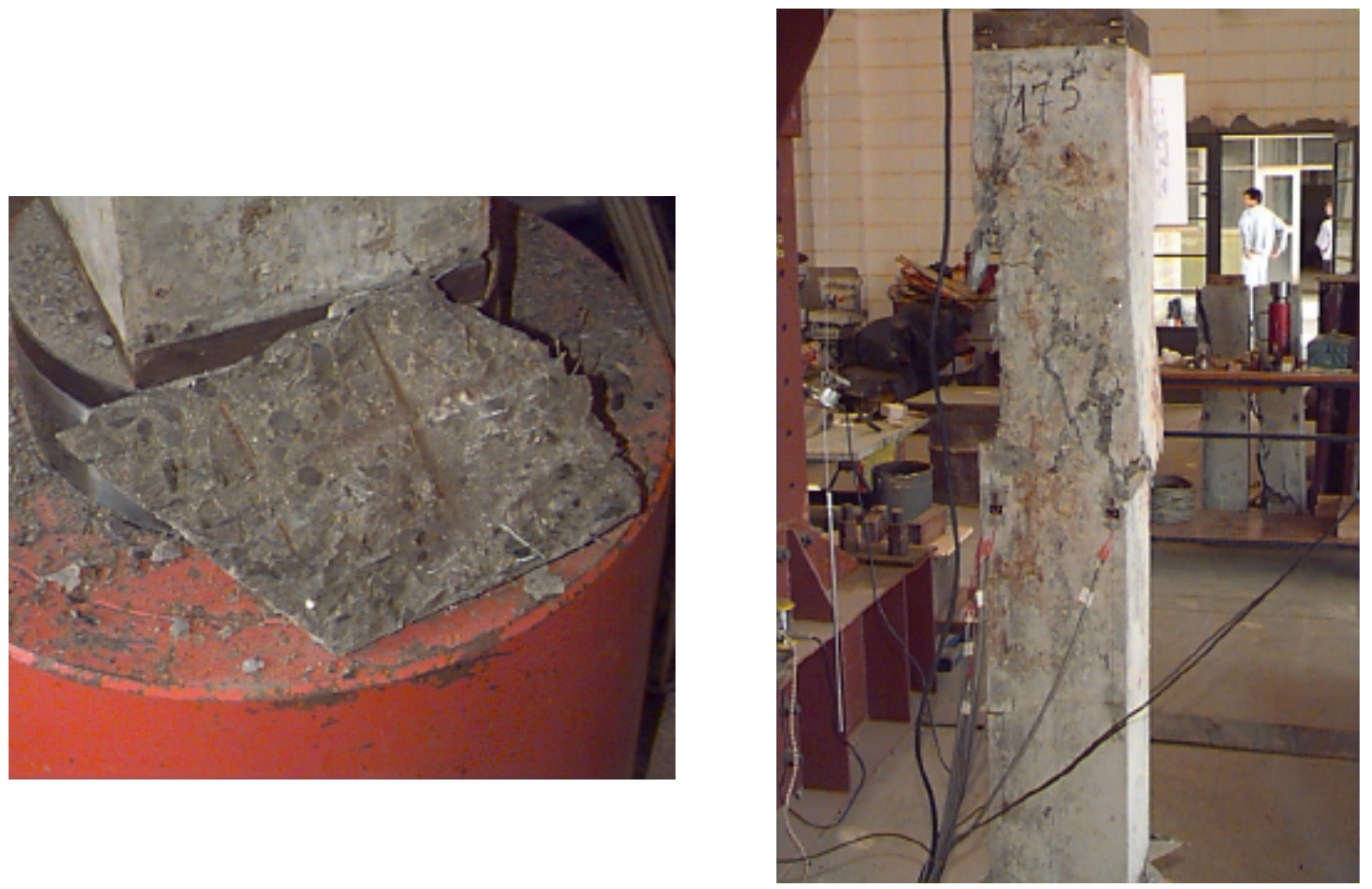

FIGURA B2 - Pilar Piloto 3 


\section{B.3 - SÉRIE P1a15}
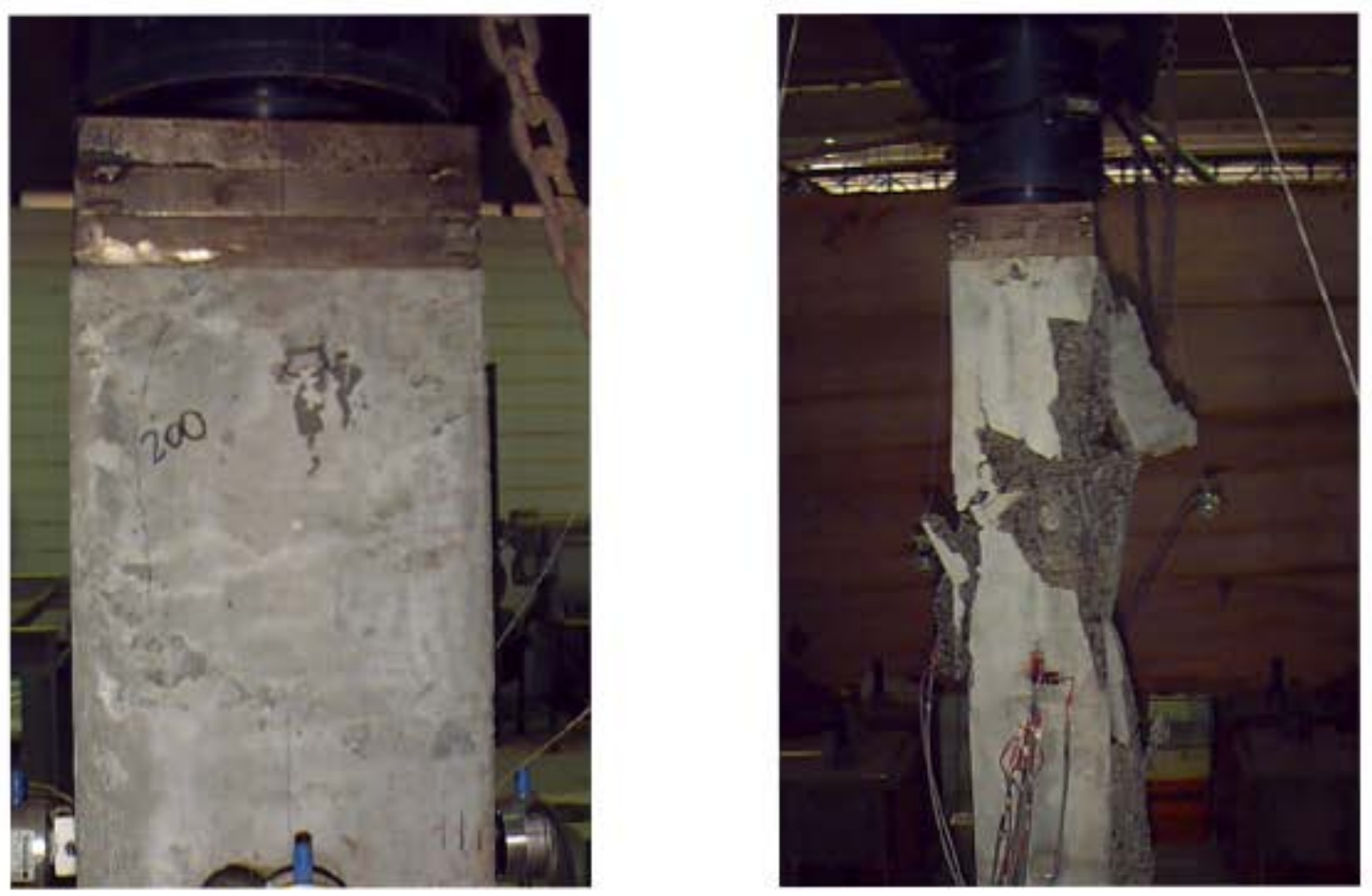

FIGURA B.3 - Pilar P1a15-1
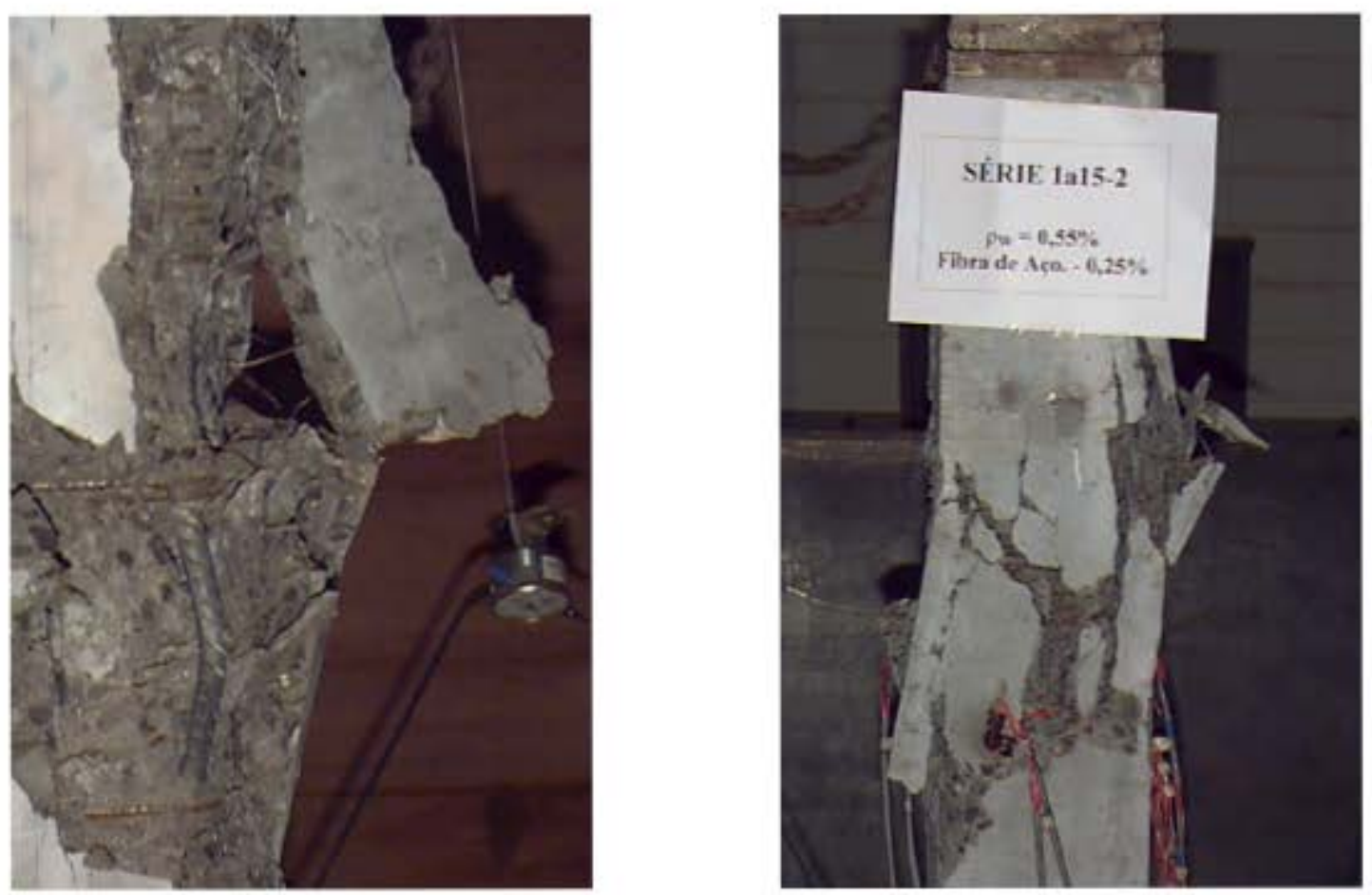

FIGURA B.4 - Pilar P1a15-2 


\section{B.4 - SÉRIE P1a10}
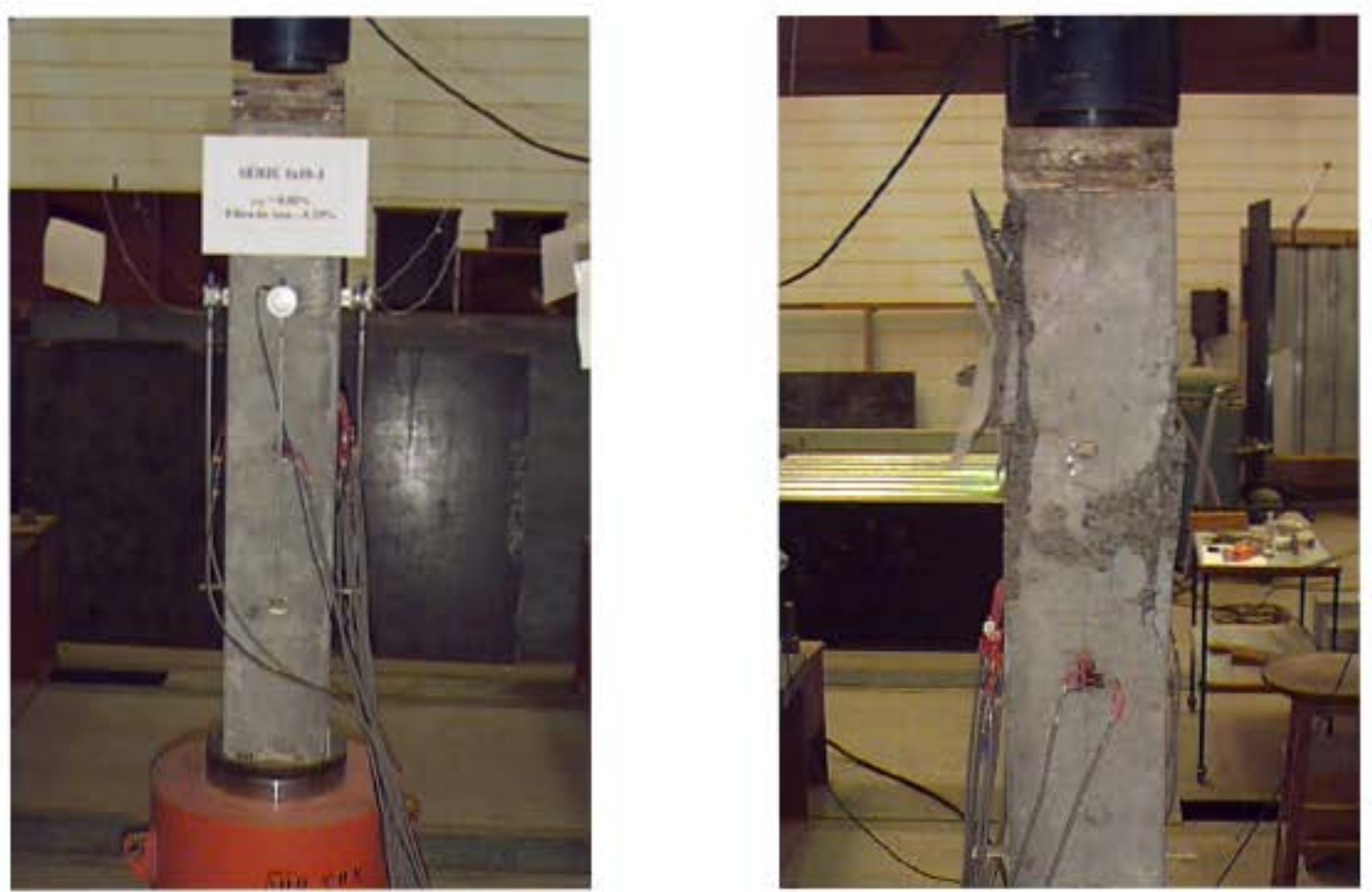

FIGURA B.5 - Pilar P1a10-1
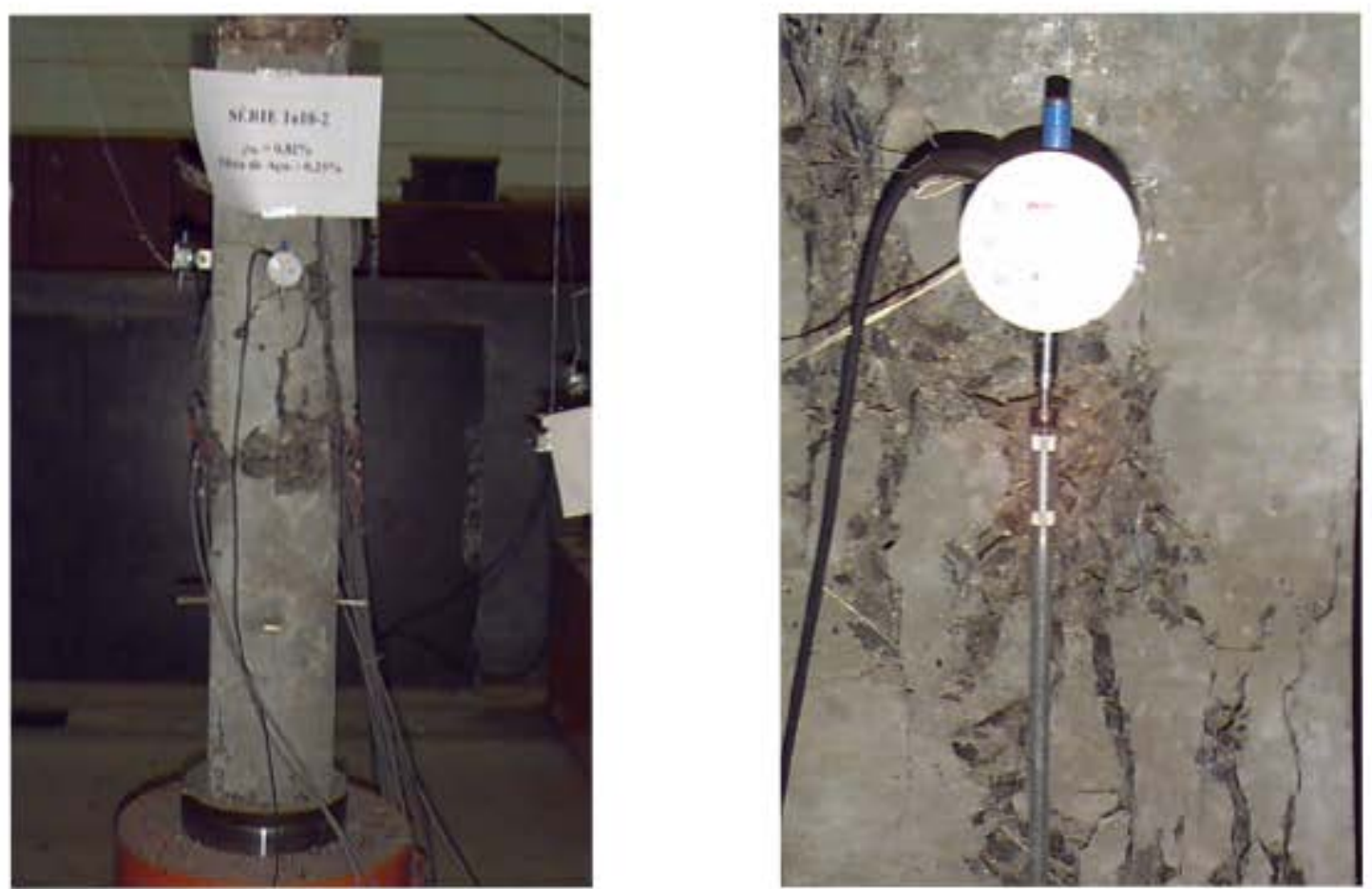

FIGURA B.6 - Pilar P1a10-2 


\section{B.5 - SÊRIE P1a05}
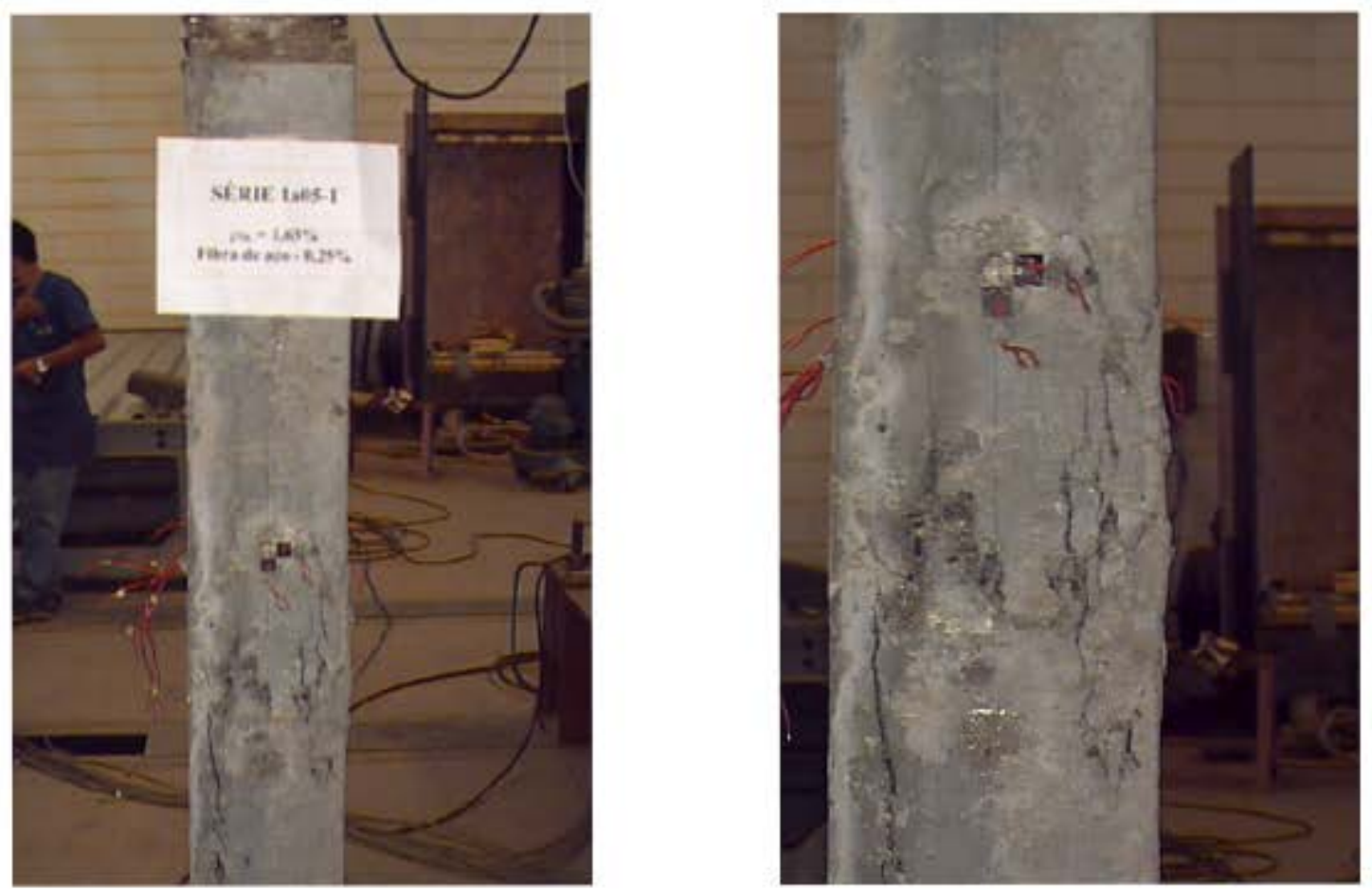

FIGURA B.7 - Pilar P1a05-1
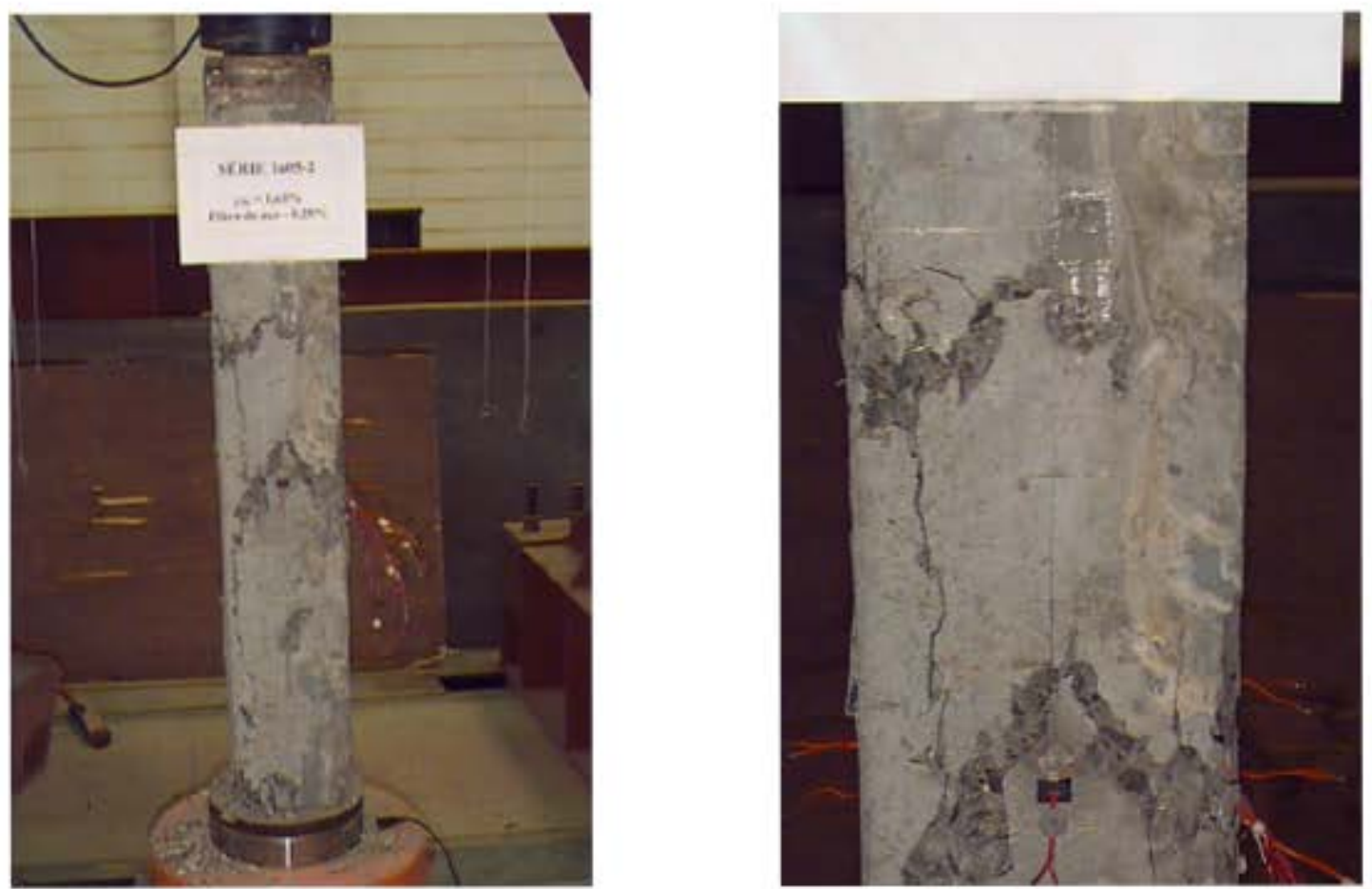

FIGURA B.8 - Pilar P1a05-2 


\section{B.6 - SÉRIE P2a15}
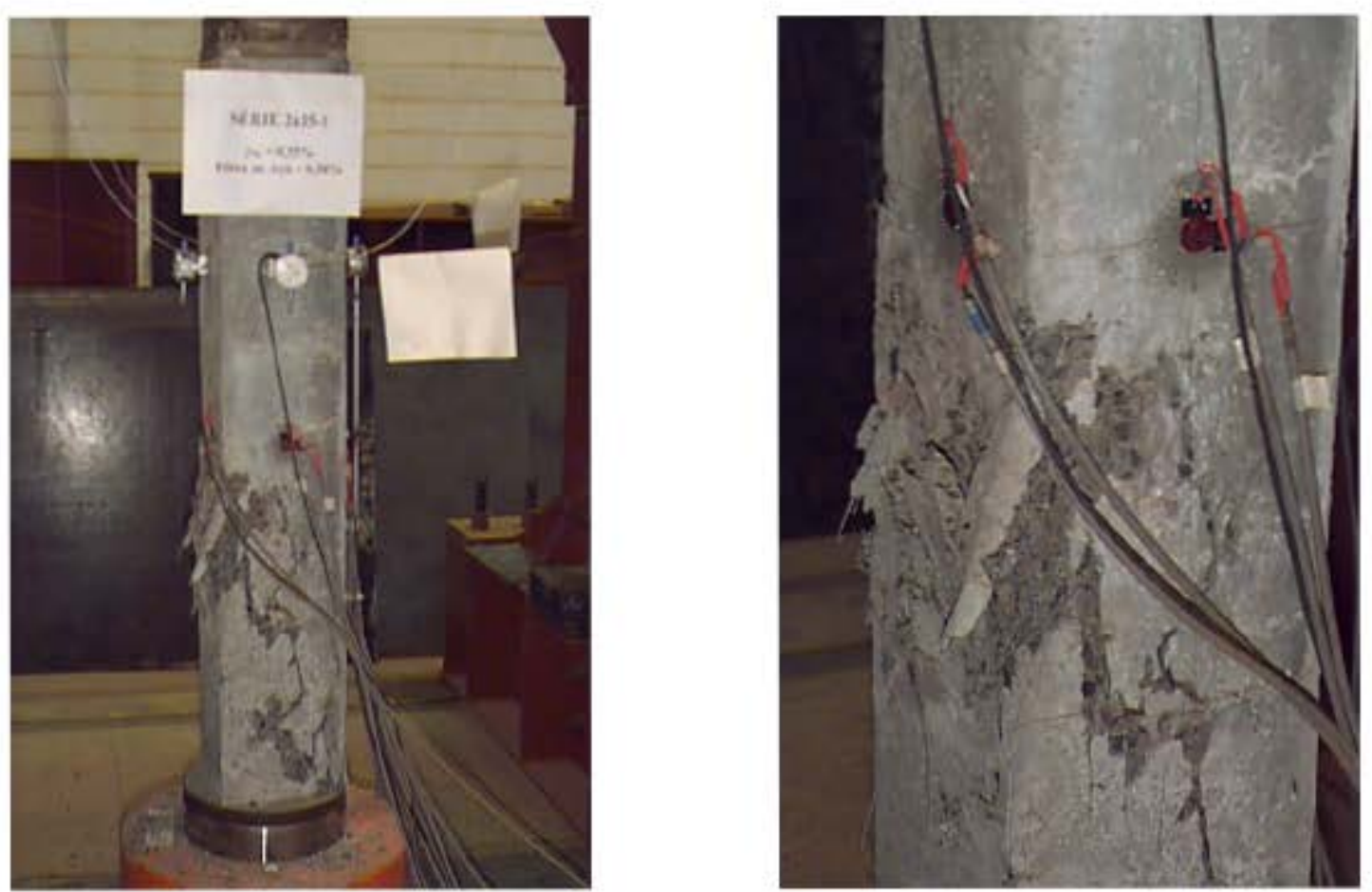

FIGURA B.9 - Pilar P2a15-1
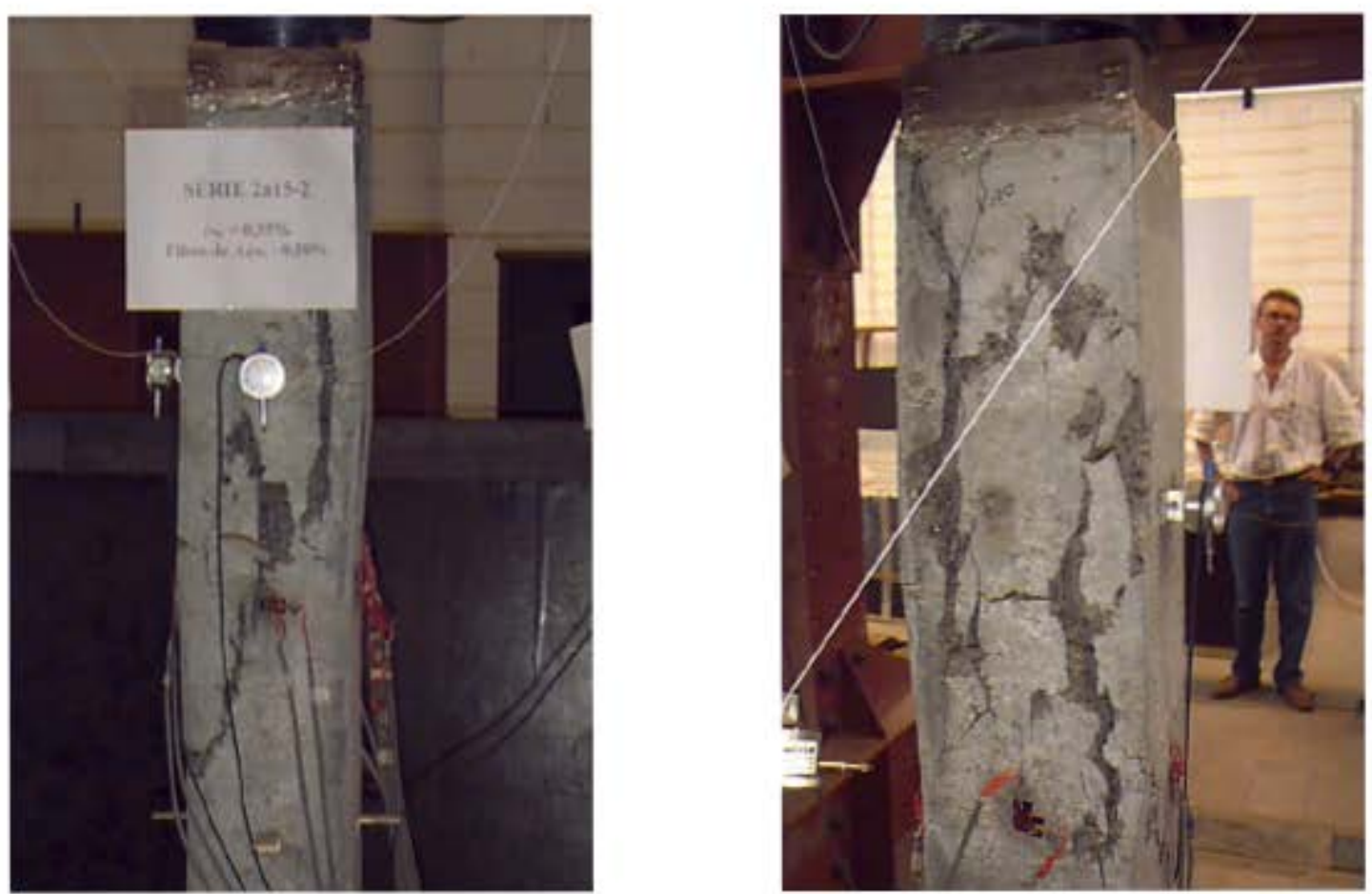

FIGURA B.10 - Pilar P2a15-2 


\section{B.7 - SÊRIE P2a15r}
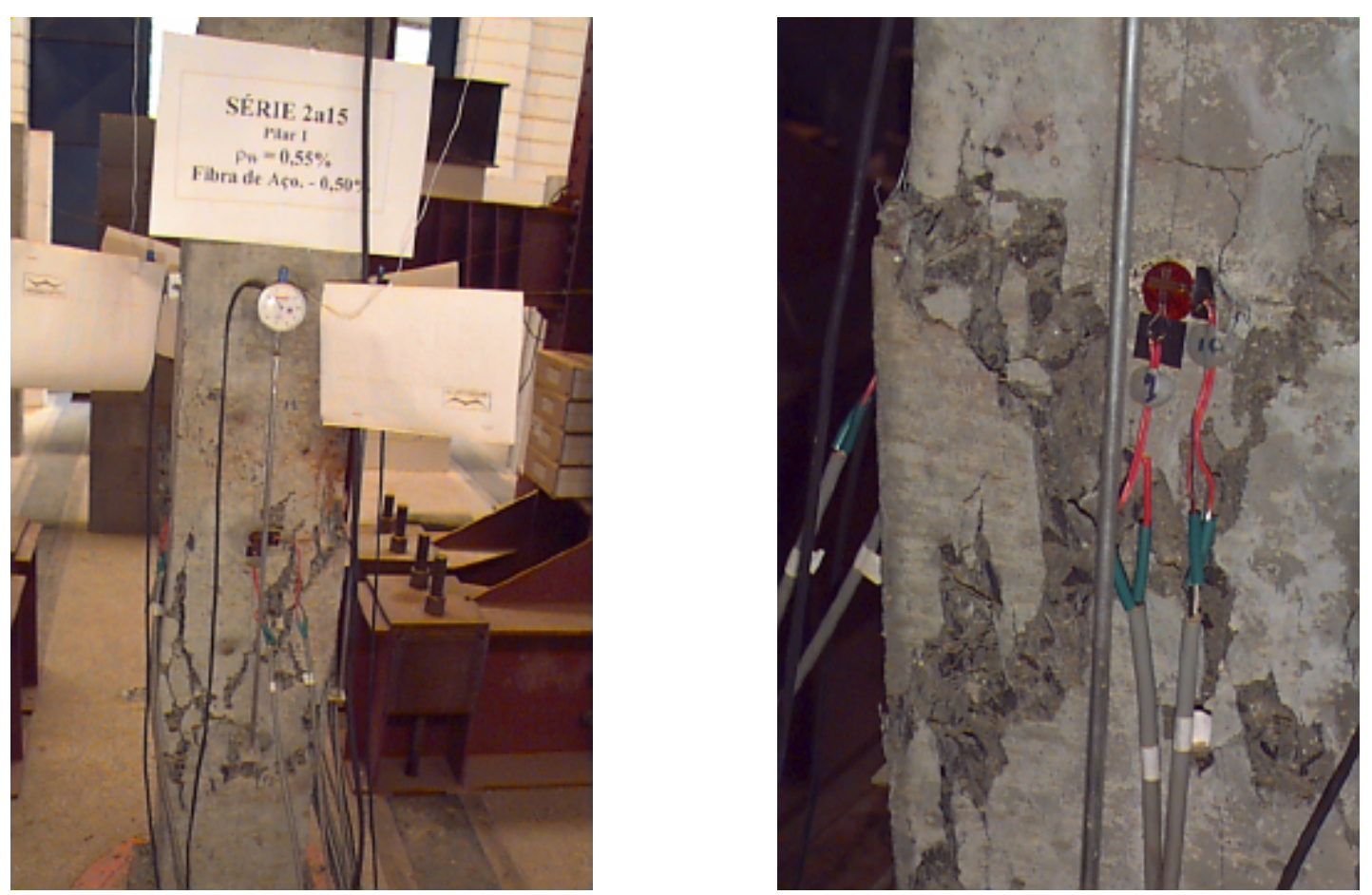

FIGURA B.11 - Pilar P2a15-1r
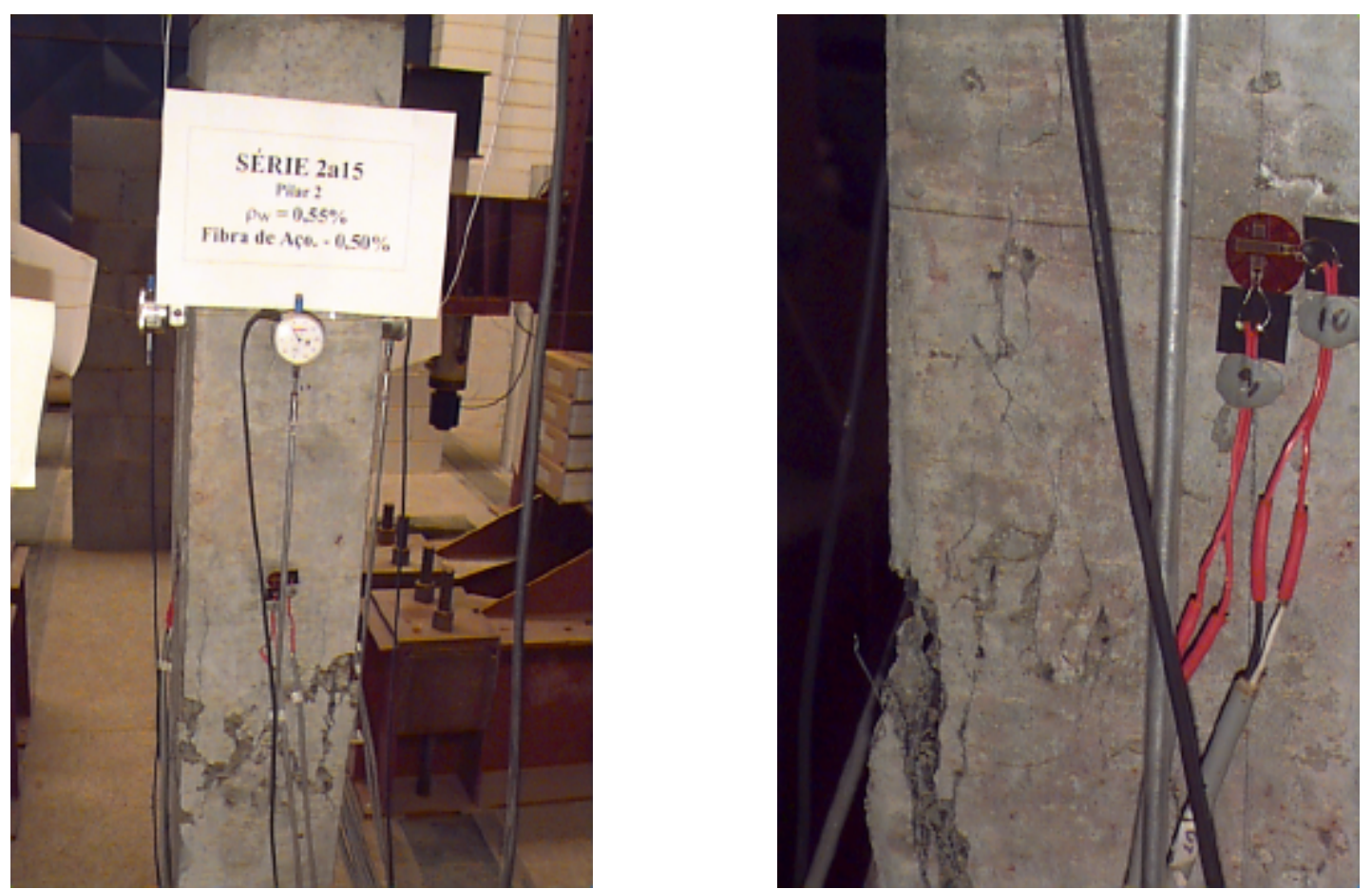

FIGURA B.12 - Pilar P2a15-2r 


\section{B.8 - SÉRIE P2a05}
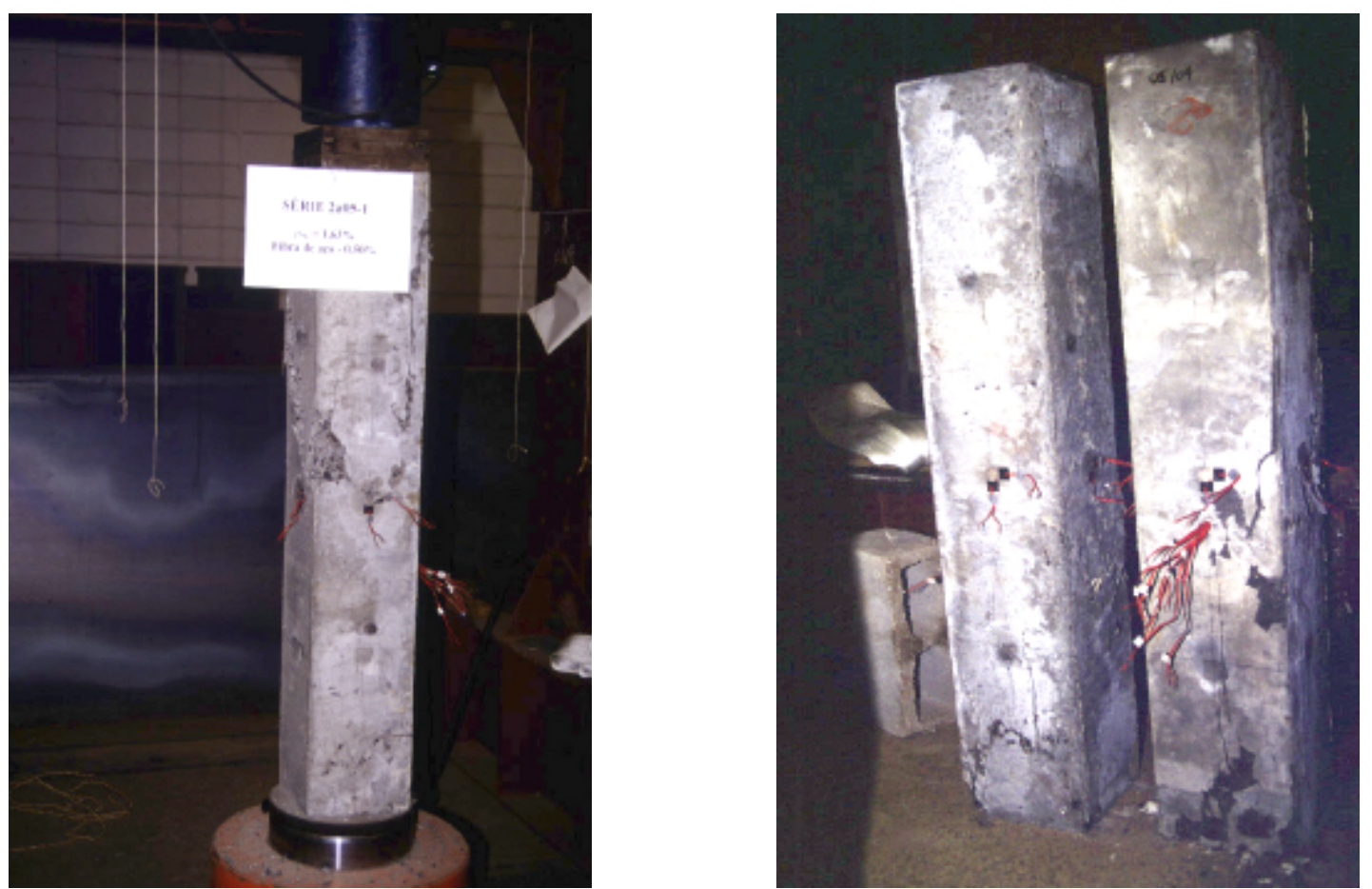

FIGURA B.13 - Pilar P2a05-1
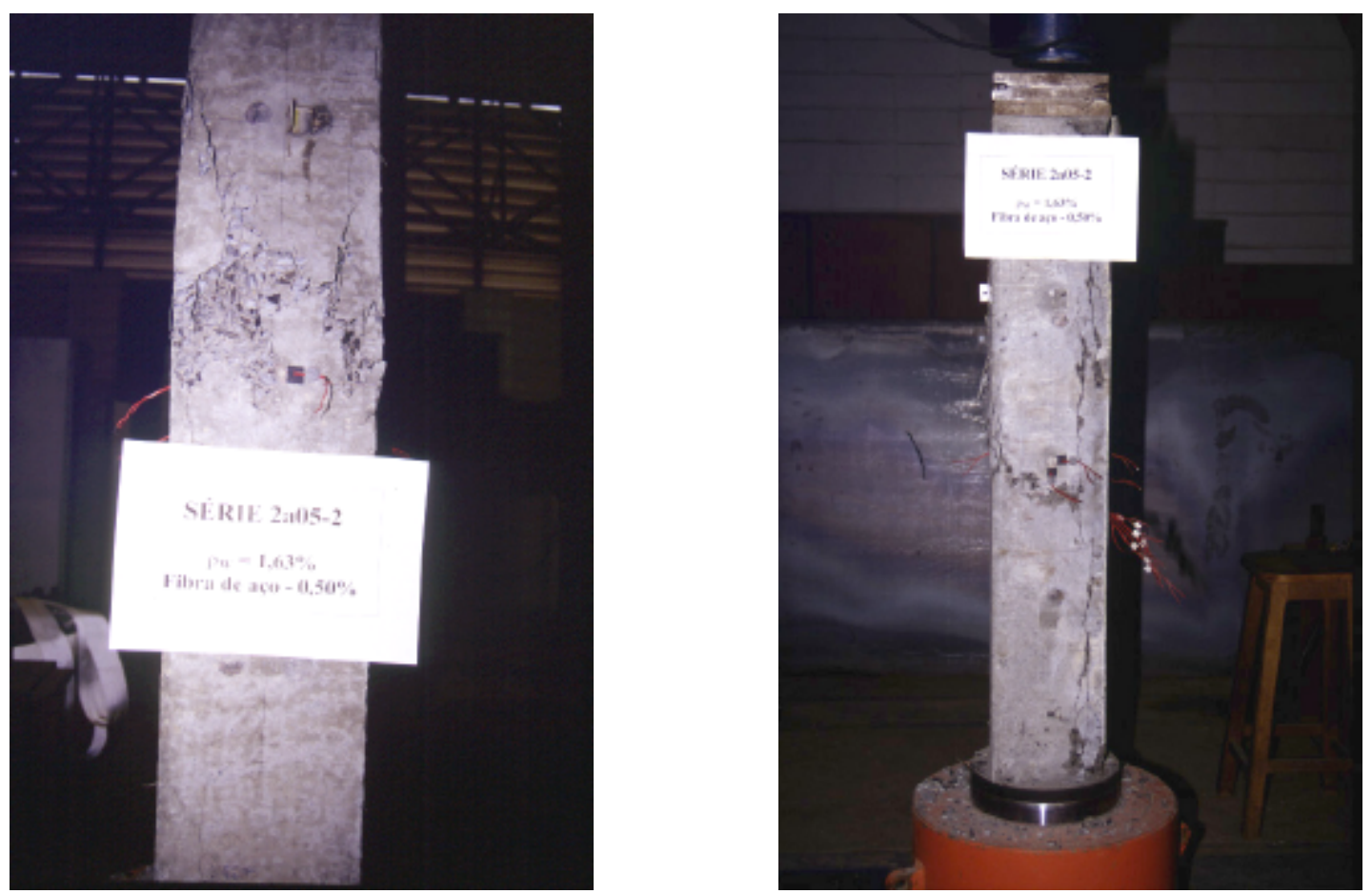

FIGURA B.14 - Pilar P2a05-2 


\section{B.9 - SÉRIE P3a15}
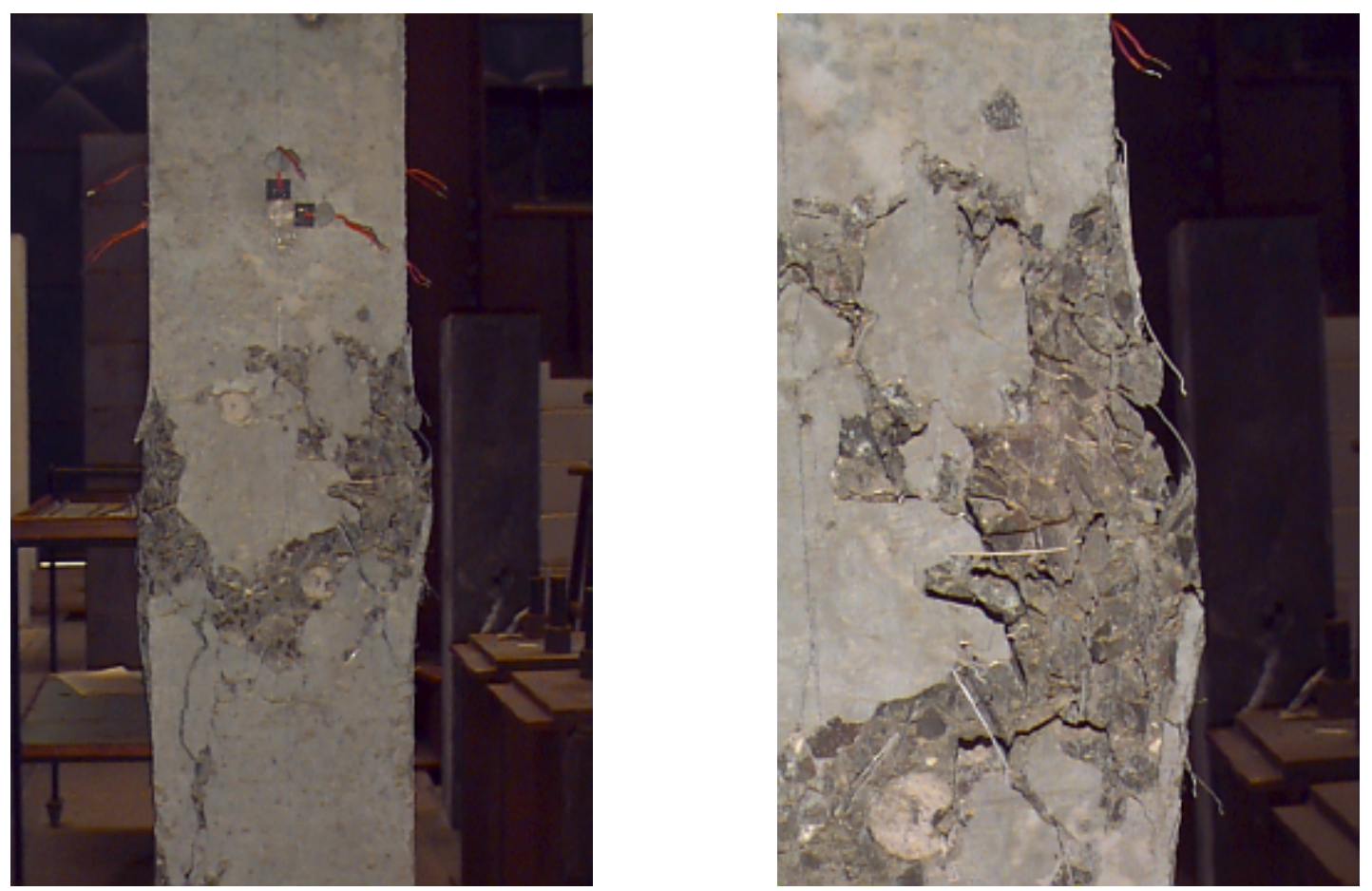

FIGURA B.15 - Pilar P3a15-1
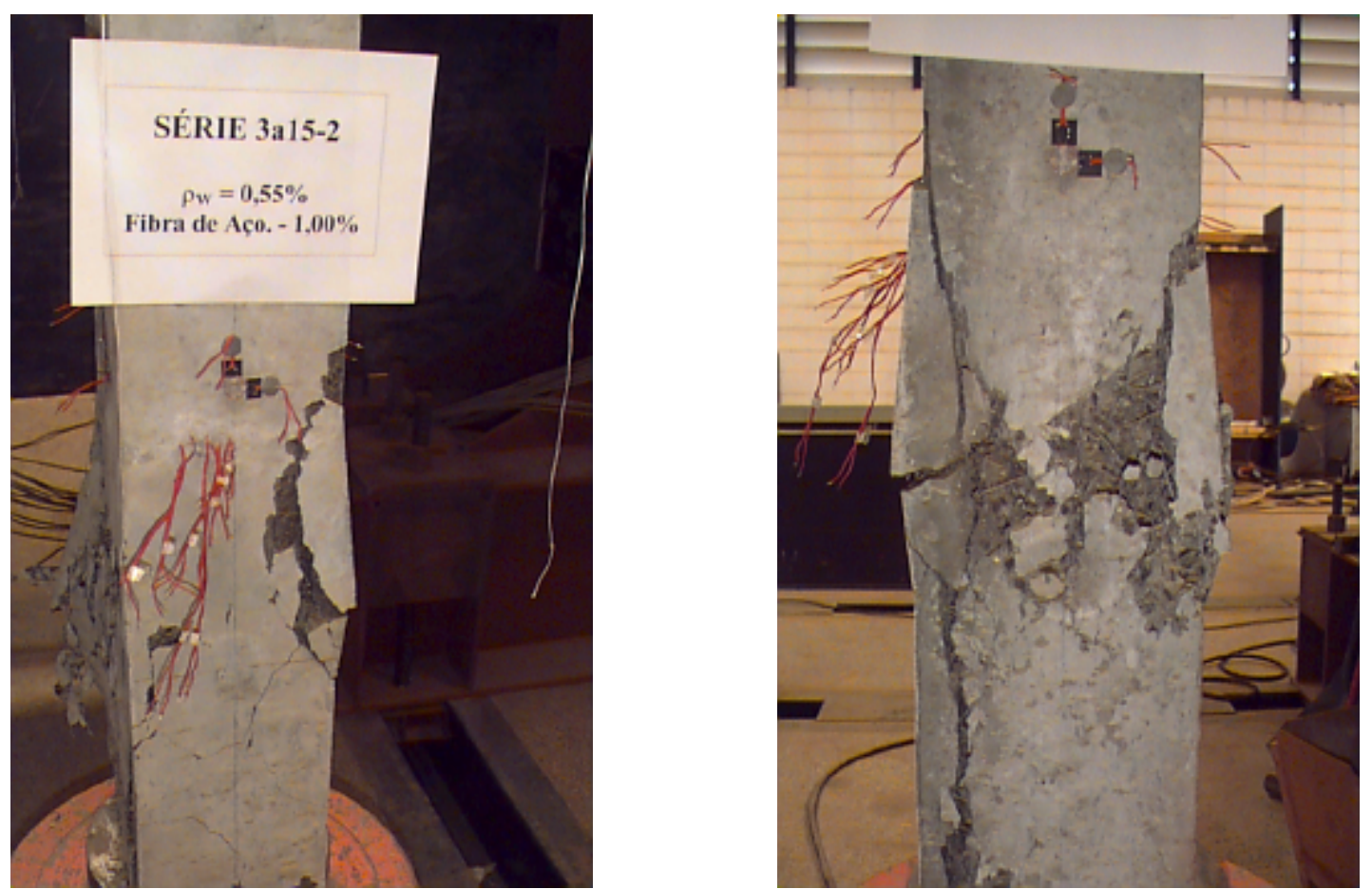

FIGURA B.16 - Pilar P3a15-2 


\section{B.10 - SÊRIE P3a10}
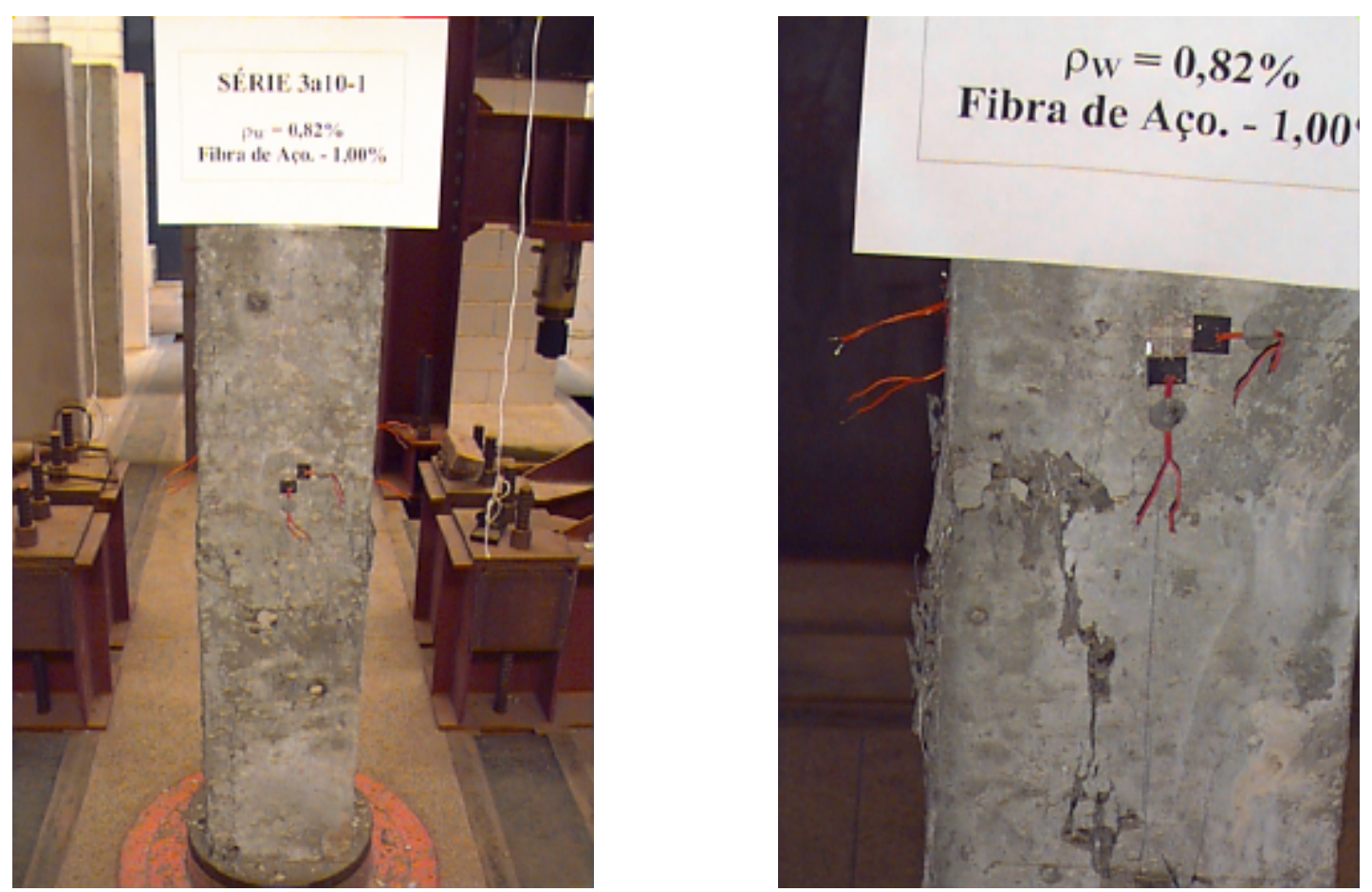

FIGURA B.17 - Pilar P3a10-1
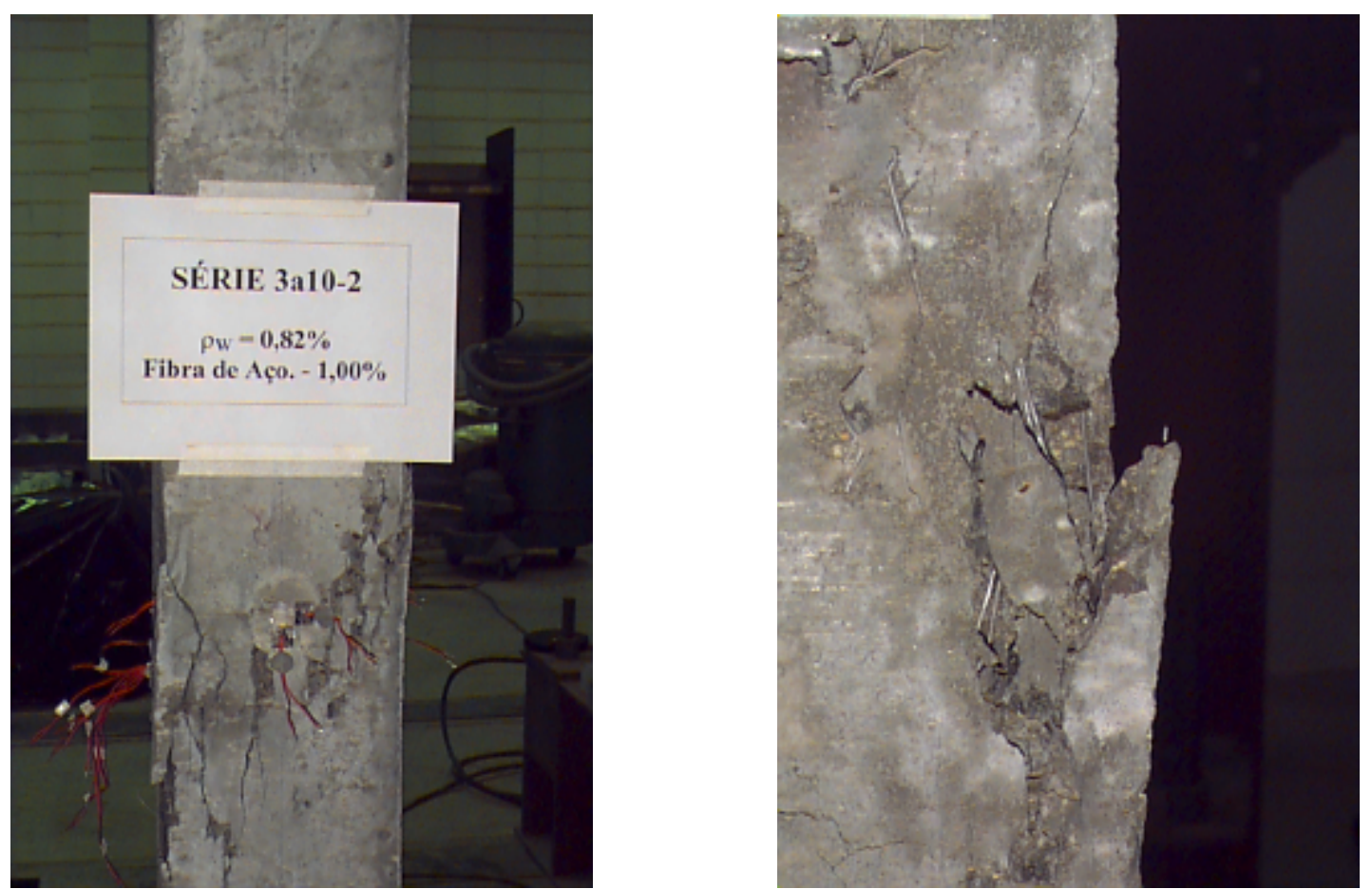

FIGURA B.18 - Pilar P3a10-2 


\section{B.11 - SÊRIE P3a05}
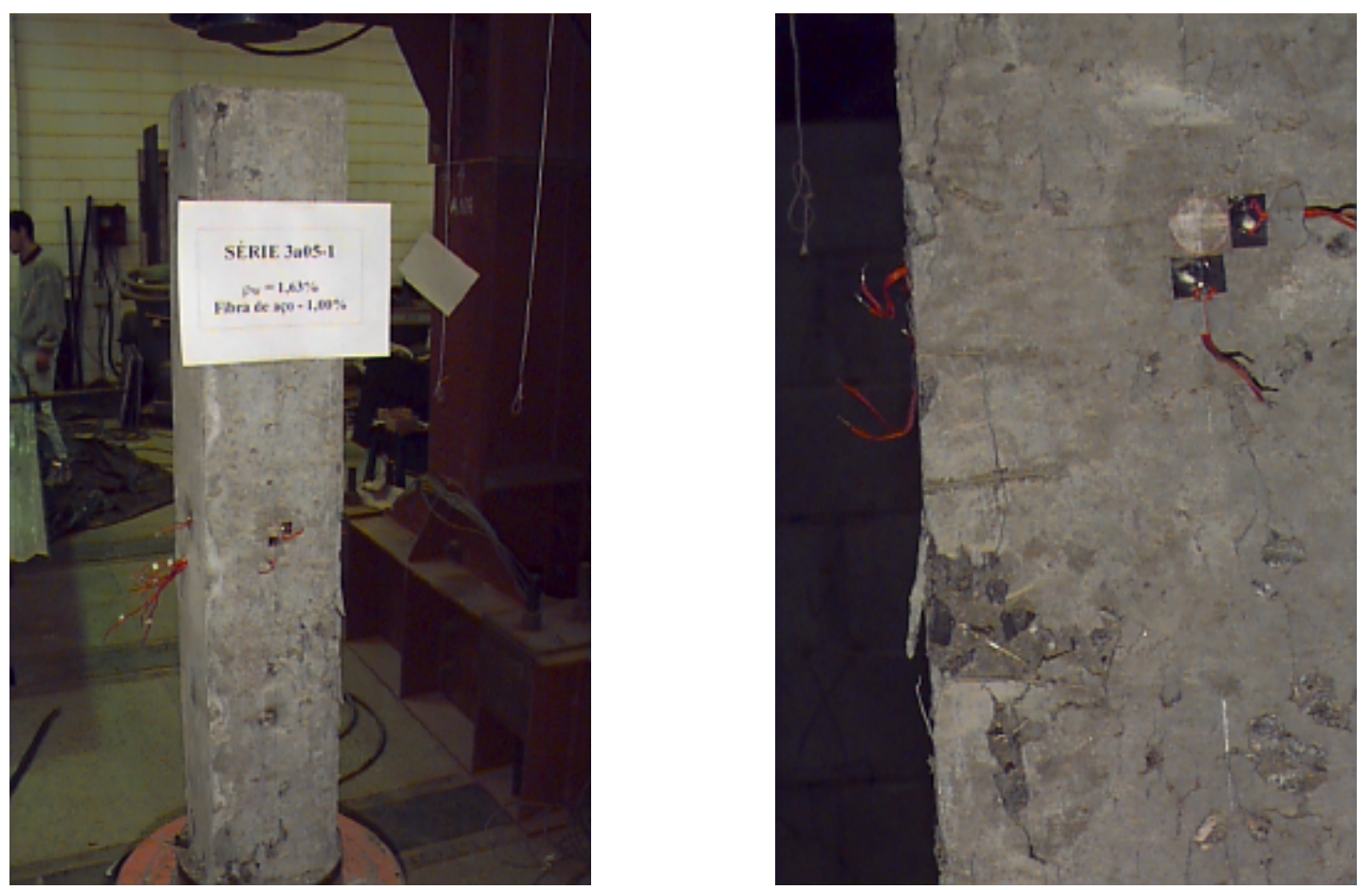

FIGURA B.19 - Pilar P3a05-1
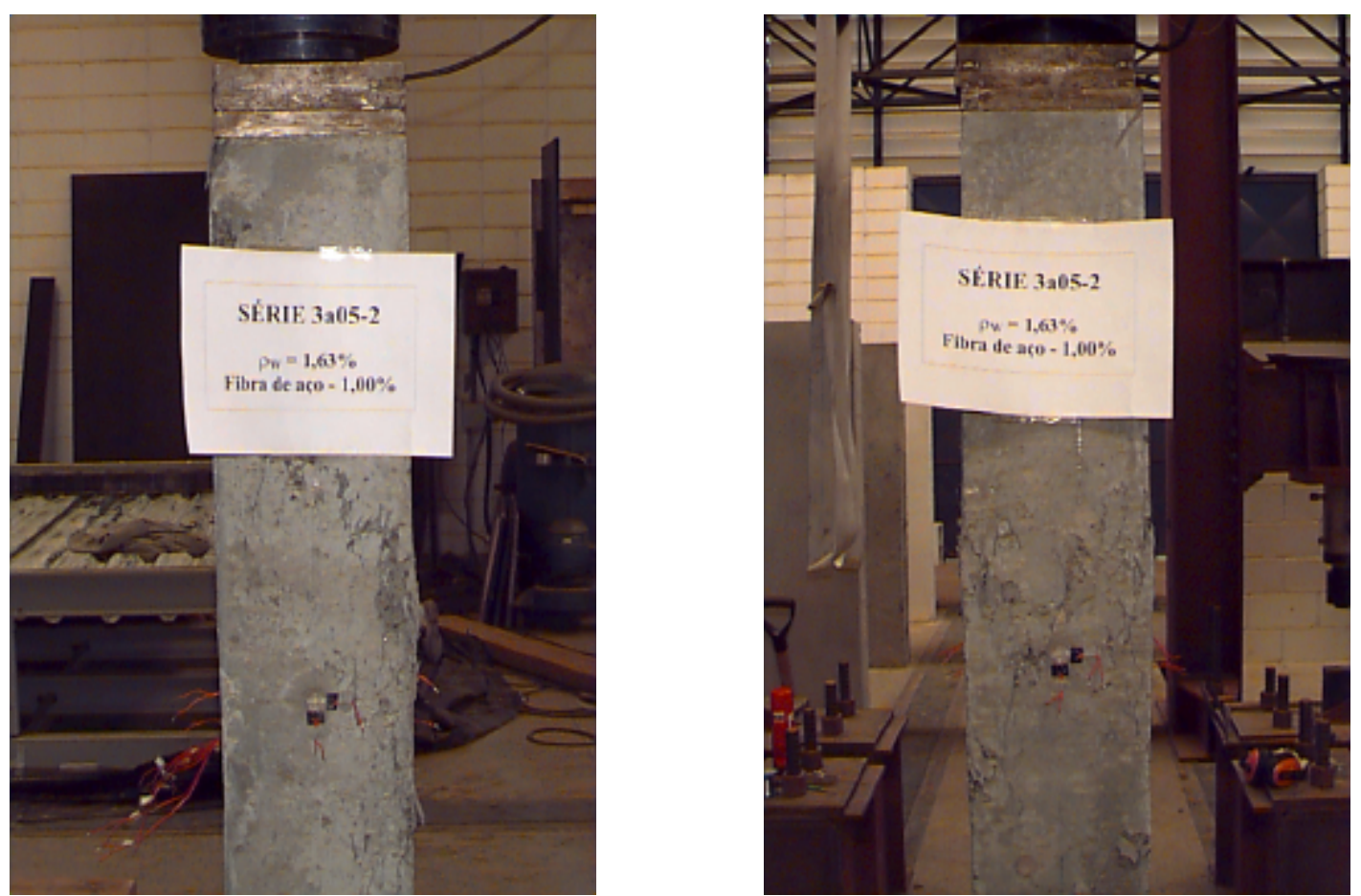

FIGURA B.20 - Pilar P3a05-2 


\section{B.12 - SÊRIE P4a15}
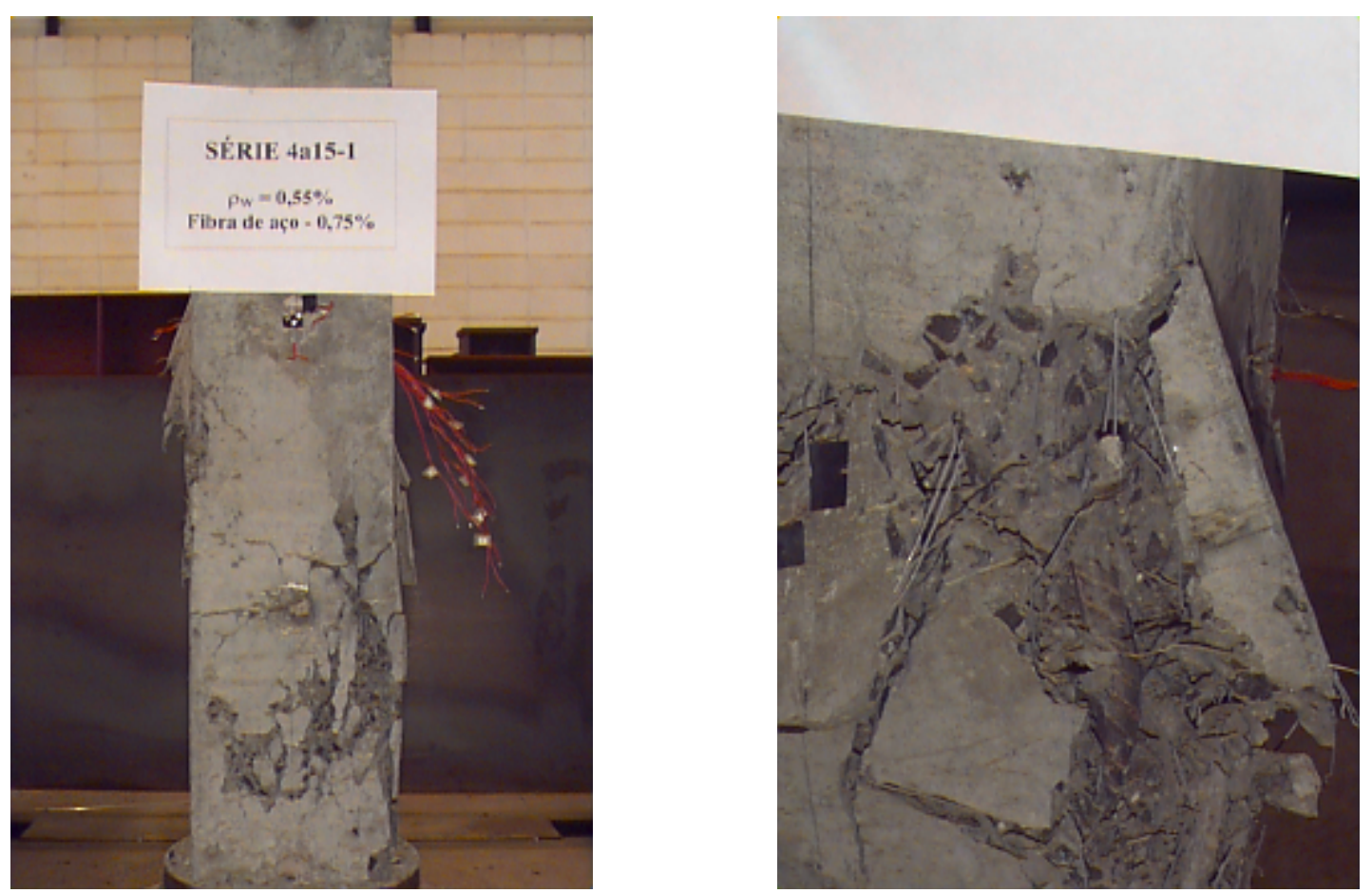

FIGURA B.21 - Pilar P4a15-1
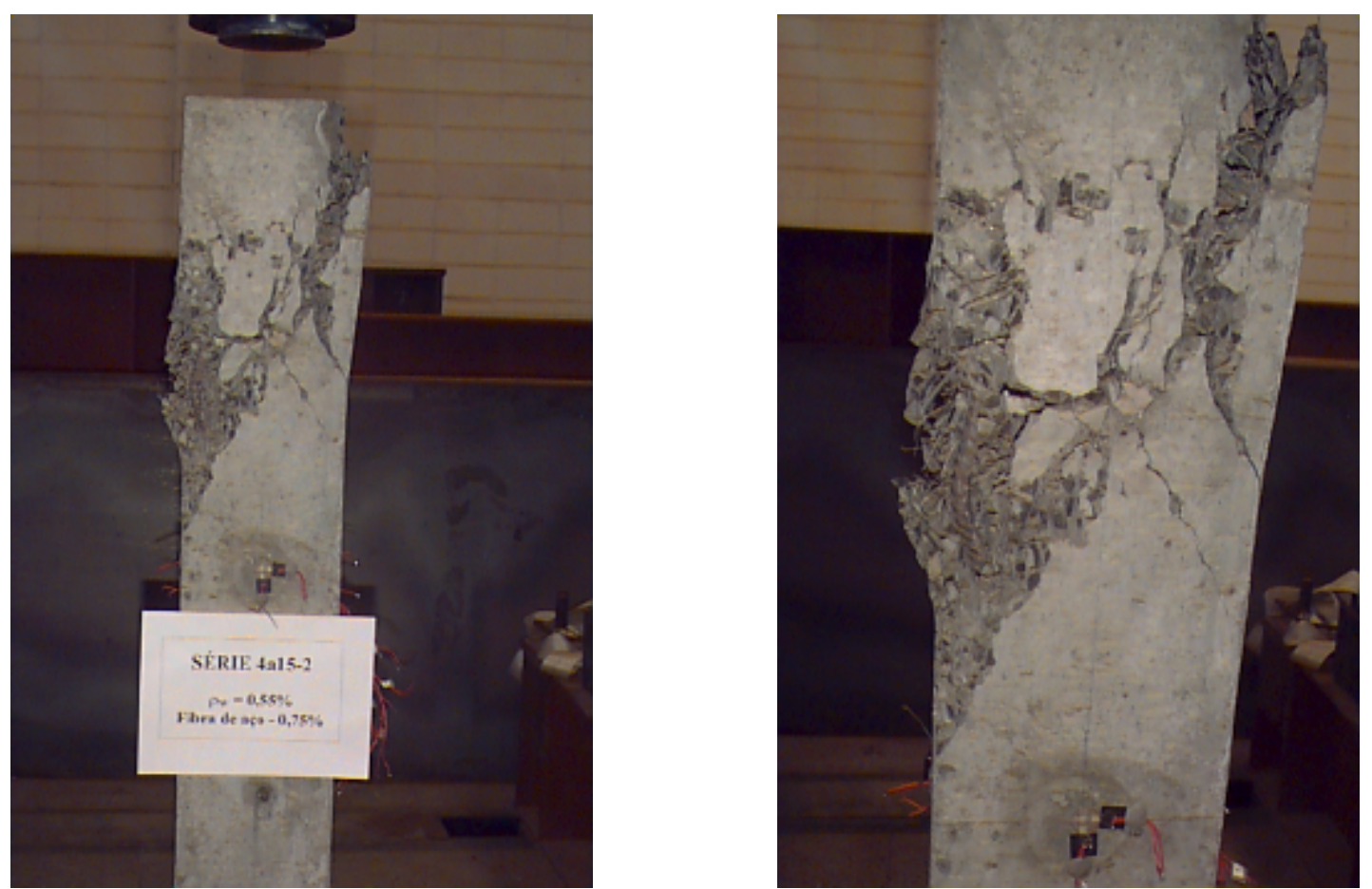

FIGURA B.22 - Pilar P4a15-2 


\section{B.13 - SÊRIE P4a10}
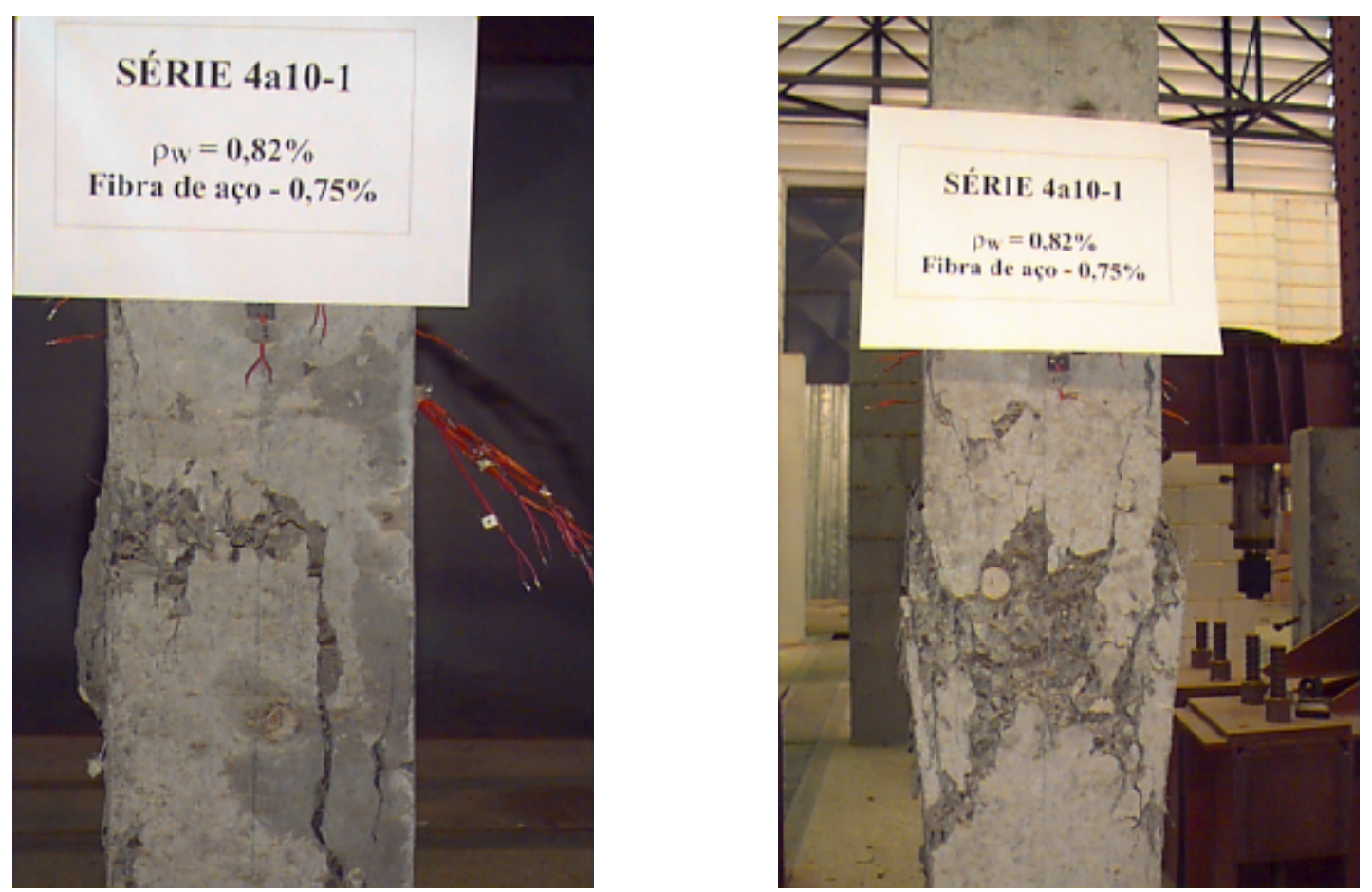

FIGURA B.23 - Pilar P4a10-1
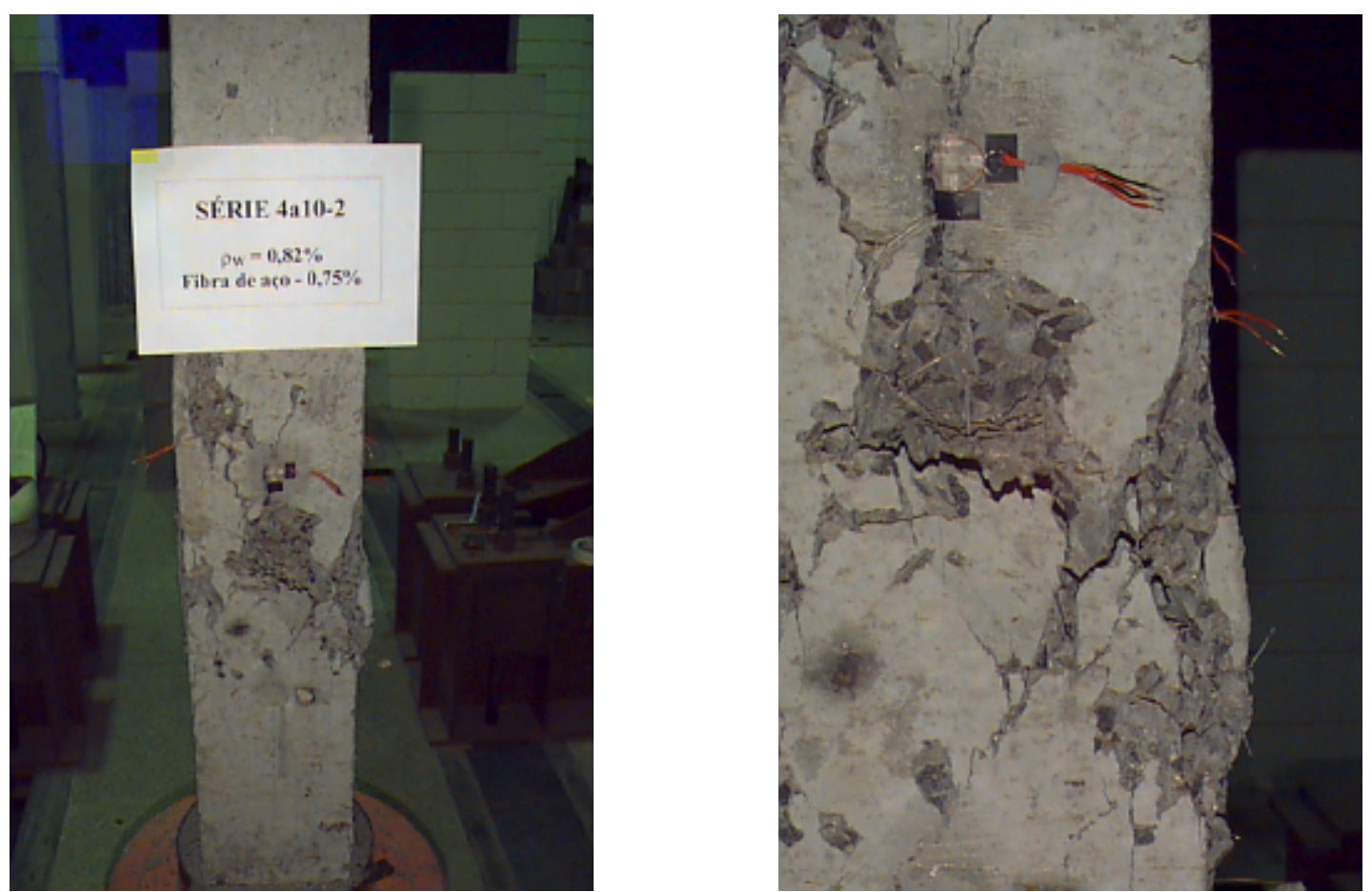

FIGURA B.24 - Pilar P4a10-2 


\section{B.14 - SÊRIE P4a05}
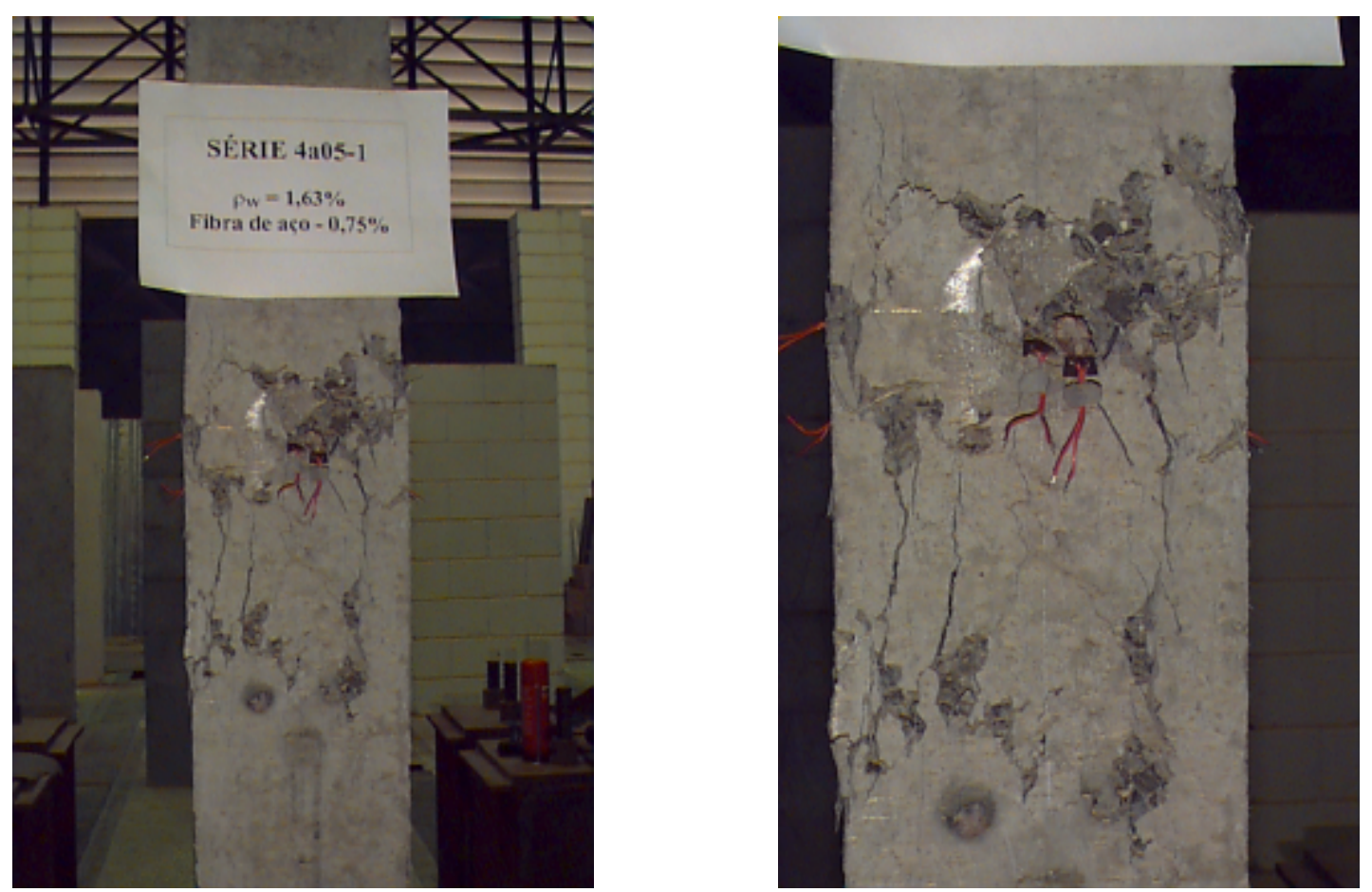

FIGURA B.25 - Pilar P4a05-1
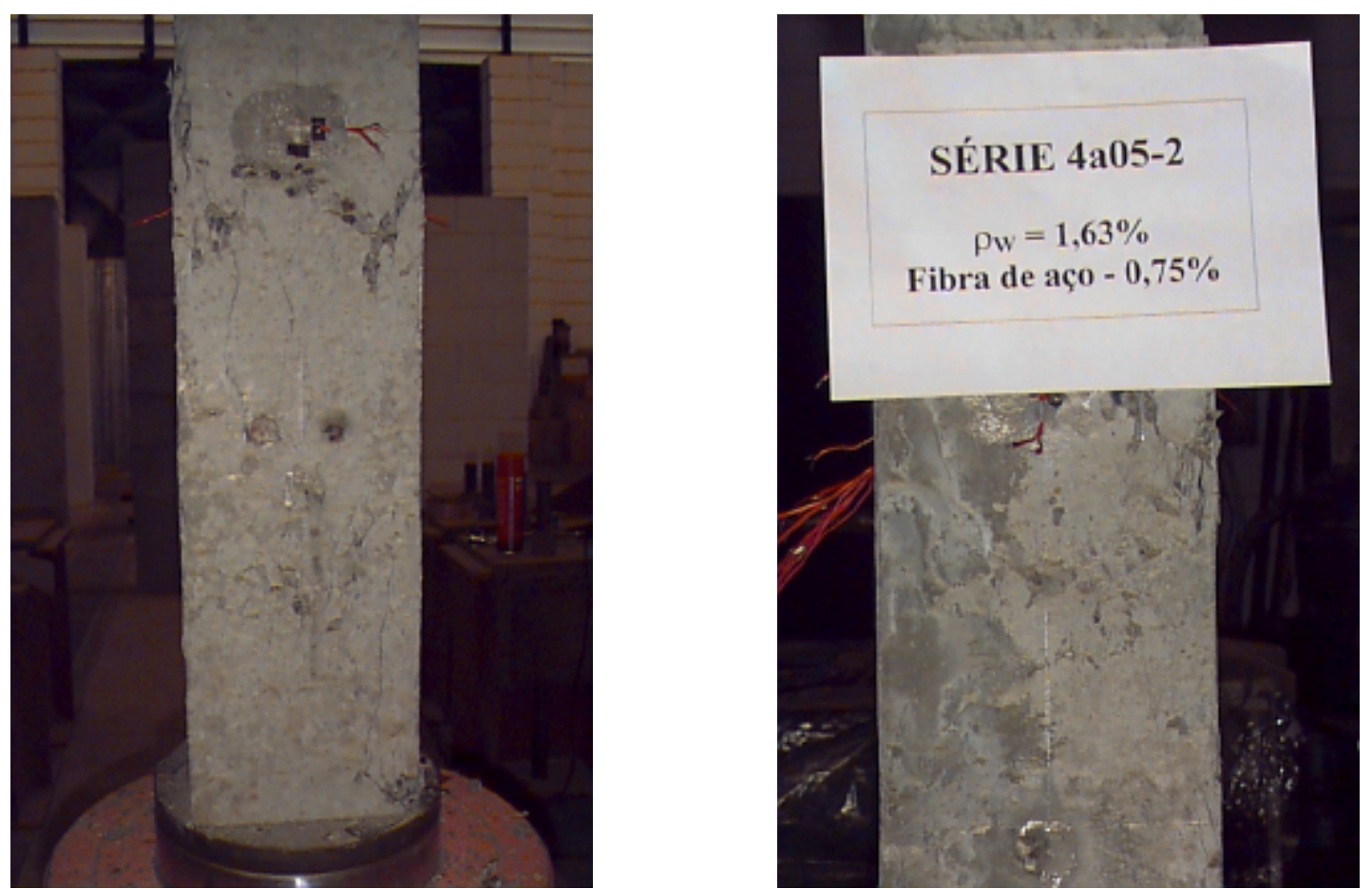

FIGURA B.26 - Pilar P4a05-2 